University of Nebraska - Lincoln

DigitalCommons@University of Nebraska - Lincoln

$12-2020$

\title{
Contextualizing a Maya Collection from Alta Verapaz, Guatemala, at the University of Ghent, Belgium
}

Julia Montoya

Investigadora independiente, Guatemala-Bélgica, julia.montoya@gmail.com

Follow this and additional works at: https://digitalcommons.unl.edu/zeabook

Part of the American Material Culture Commons, Indigenous Studies Commons, Latin American Languages and Societies Commons, Museum Studies Commons, and the Other History of Art, Architecture, and Archaeology Commons

\section{Recommended Citation}

Montoya, Julia, "Contextualizing a Maya Collection from Alta Verapaz, Guatemala, at the University of Ghent, Belgium" (2020). Zea E-Books. 98.

https://digitalcommons.unl.edu/zeabook/98

This Book is brought to you for free and open access by the Zea E-Books at DigitalCommons@University of Nebraska - Lincoln. It has been accepted for inclusion in Zea E-Books by an authorized administrator of DigitalCommons@University of Nebraska - Lincoln. 


\section{CONTEXTUALIZINC A maYA COLLECTION FROM ALTA VERAPAZ, GUATEMALA AT THE UNIVERSITY}

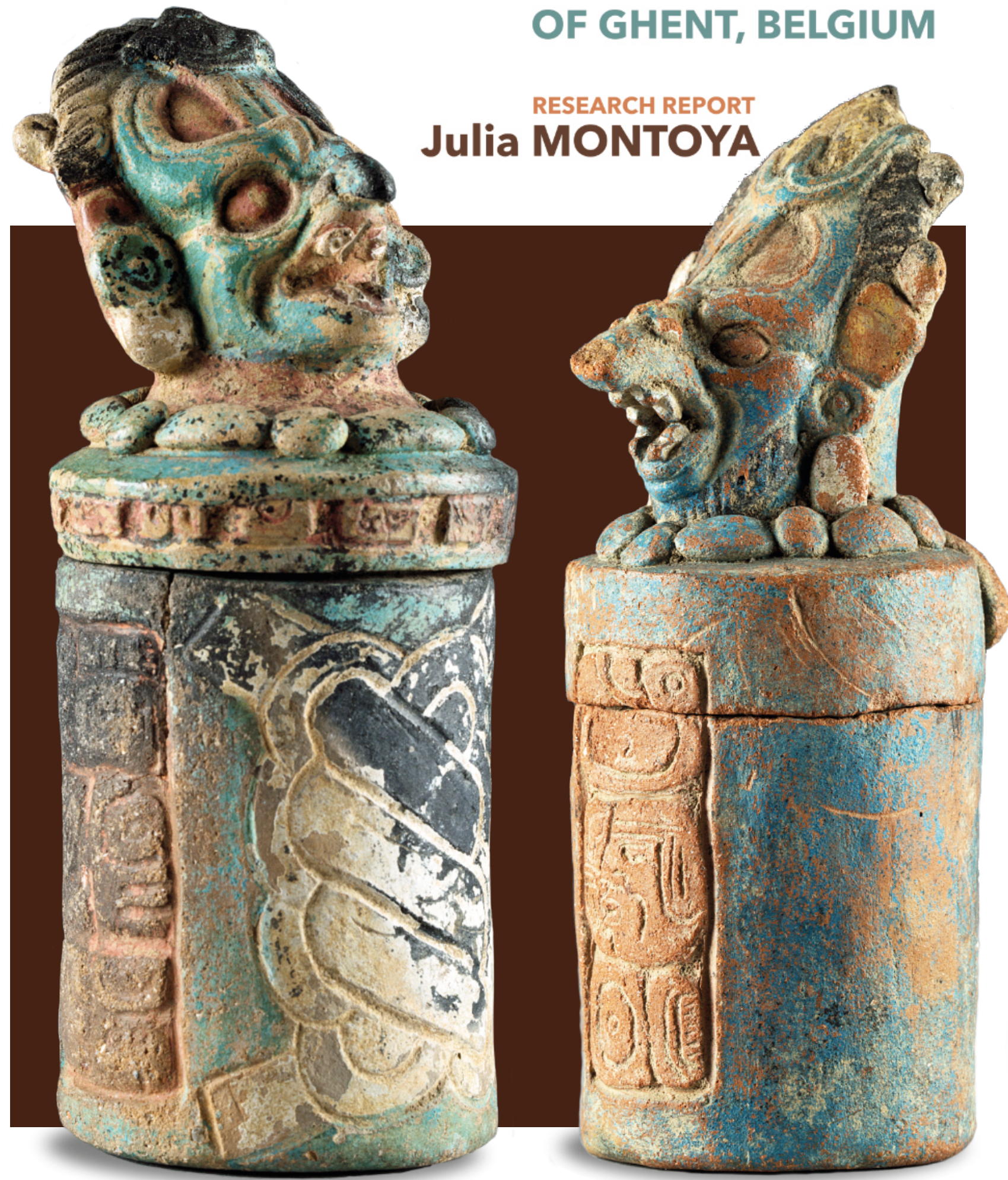




\section{CONTEXTUALIZING \\ A MAYA COLLECTION FROM ALTA VERAPAZ, GUATEMALA}

AT THE UNIVERSITY OF GHENT, BELGIUM ${ }^{1}$

\section{RESEARCH REPORT \\ Julia Montoya}




\section{COLOPHON}

Copyright @ 2020 Julia Montoya

ISBN: 978-1-60962-188-9

DOI (Digital Object Identifier): 10.32873/unl.dc.zea.1274

All rights reserved. No part of this publication may be reproduced or transmitted in any form without prior permission from the author.

Requests for information or permission to reproduce material from this work should be sent to the author: julia.montoya@gmail.com

Design: Jan De Meyer (studio dARTanjan), jandartanjan@gmail.com

Type: Hoefler Text \& Avenir Next

Illustrations:

Cover: artifacts EVUG GE I 00044 and 00045

Back cover: artifacts EVUG GE I 00114; 00022 and 00042 (detail)

Photographs (C) Tom Debruyne and Julia Montoya

Electronic publication (pdf) available at https://digitalcommons.unl.edu/zeabook/

Print edition available from http://www.lulu.com/spotlight/unllib

Zea Books are published by the University of Nebraska - Lincoln Libraries

UNL does not discriminate based upon any protected status.

Please go to http://www.unl.edu/equity/notice-nondiscrimination

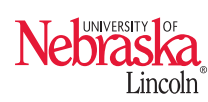




\section{CONTENTS}

1. FOREWORD _ 7

2. INTRODUCTION

3. SETTLEMENT PATTERNS OF THE GUATEMALAN HIGHLANDS _ 15

4. ARCHAEOLOGICAL SITE

1. Archaeological surveys of Chich'en _... 21

2. Geographical setting 23

3. Sacred landscape _._. 25

4. Name of the site _._. 27

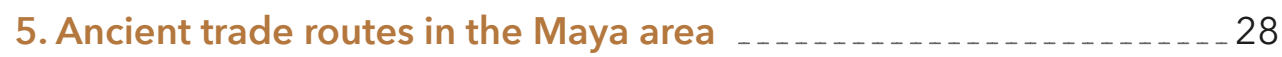

6. Pilgrimage routes 31

7. Brief description of the site

8. Current situation of the site (2017) _ 37

9. Habitat and society of Chich'en from the Late Classic to the Postclassic period

5. EARLY COLONIAL PERIOD

1. Spanish military campaigns _...... 41

2. Arrival of the Dominican friars to Tezulutlán _ 43

3. Foundation of San Juan Chamelco _.

4. Foundation of Santo Domingo de Cobán _................ 47

5. Visit of the Q'eqchi' lords to the Spanish Court _........ 49

6. Last days of Don Juan Matac (Matal) B'atz _........... 50

7. Continuity and identity

6. EXCAVATION OF GEORGES LÉGER IN 1894

7. GENERAL DESCRIPTION OF THE CHICH'EN COLLECTION

8. ICONOGRAPHIC ANALYSIS

1. Representation of deities _. 65

1.1. K'awiil _ 65

1.2. K'awiil / Itzamnaaj 68

1.3. Jaguar God of the Underworld _._._._._._._._._._. 72

1.4. One Ixim / One Ajan, the Maize God _._. 
2. Royalty attributes _... 81

2.1. The mat or jal-sign _._.

2.2. Jade ornaments _. 83

2.3. Feathers _._. 85

2.4. "Maya blue"

3. Symbolism of the ballcourt _._. 87

9. PRELIMINARY CONCLUSIONS _... 91

10. FINAL COMMENT _. 93

11. NOTES _. 96

12. REFERENCES

13. ANNEXES

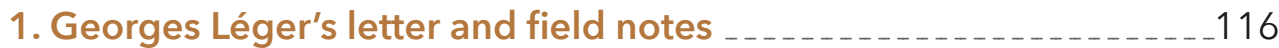

2. Hieroglyphic inscriptions:

An interpretation by Rogelio Valencia Rivera _._._._._._._._._. 126

3. Registration numbers and measurements

of the artifacts .

4. Artifacts in other Maya collections

resembling pieces from Chich'en

14. ILLUSTRATION CREDITS

15. ACKNOWLEDGMENTS 


\section{FOREWORD}

${ }^{6}$ Many objects created by different peoples and cultures of the world that once formed part of their cultural heritage are now scattered all over the globe.

Any possible information on their provenance can only be found bidden away in the archives of the institutions that hold them, which are often fragmentary and difficult to access. Hence, the only way to bring these pieces back together (if only virtually) and recontextualize them is through the publication of object biographies. Despite the limited information about their archaeological context, many pieces can bold a wealth of information, especially in the light of what the ever-increasing scientific knowledge and technical possibilities provide us.

Not studying and publishing these objects denies us the possibility to learn more from otherwise mute archaeological material."

After Martin E. Berger (2019:II2-II4)

The aim of the present study is to contextualize a collection of Maya artifacts that have been kept for 125 years at the University of Ghent, in Belgium. The objects came from one of the first archaeological excavations carried out in Guatemala, between I880 and I90o.

The collection includes 130 pottery pieces, 64 jadeite pieces, 24 stone objects (serpentine, silex, and other stones), and 52 obsidian pieces. The study started in 2016, with the identification and location of the provenance site, which was visited in 2017 . The phases of documentation and photographic registration of the objects were completed in 2019. It is the intention to digitize the collection and make it available to scholars for further research.

This report presents a brief description of the site, Chich'en, and analyzes aspects of its geographical environment, as well as the historical and religious context that determined its relevance from the Classic period to the Late Postclassic and the early colonial period. A selection of the objects is presented, and outstanding iconographic elements are analyzed. The analysis is based on a bibliography review in the fields of archaeology, history, and ethnology in the Maya region and in Mesoamerica in general. 


\section{INTRODUCTION \\ A MAYA COLLECTION IN BELGIUM}

$\mathrm{T}$

he art and culture of the ancient Maya caught the attention of European scholars after John Lloyd Stephens and Frederick Catherwood traveled to the Mayan lands in I839 and began to publish their stories in I84I, which were magnificently illustrated by Catherwood (Stephens 1969; Bourbon 1999). They were the first to issue detailed images of cities, monuments, and texts, promoting the notion and existence of a highly developed civilization. The ancient Maya became a focus of popular fascination.

After independence from Spain in I82I, liberal governments stimulated the economic growth of the young Republic of Guatemala with the help of foreign investment. Extensive concessions were granted for exploitation and development. This neo-colonial system led to an important European immigration. In I84I the Compagnie Belge de Colonisation established the first Belgian colony in Santo Tomás de Castilla (on the Atlantic coast). By I853, the Belgian concession in Guatemala was officially ended by the Guatemalan government since it had not complied with any of its contractual obligations. In the following decades, Germans began to settle in Guatemala, especially in the fertile area of Verapaz. They built an economic empire based on the production and export of coffee to Germany and England (Matton 2015:2-24; see also Wagner 200I). ${ }^{2}$ The geographer and explorer, Karl Sapper and the entrepreneur Erwin Paul Dieseldorff devoted themselves to Maya archeology and the study of the culture and religion of the Q'eqchi'-Maya. They carried out the first archeological excavations in Guatemala, between I88o and I890. Others followed their example, and in 1894, the Belgian Georges Léger, then consul in Cobán, undertook the excavation of two mounds located in Finca Chichen, a private hacienda south of the city of Cobán (Figures I and 2).

Meanwhile, in Belgium, growing interest in the cultures of pre-Columbian Central and South America was evident during the Congress of Americanists held in Brussels in I879. In I895, Professor A. De Ceuleneer, from the University of Ghent, bought a group of Maya artifacts from Georges Legèr. The objects became part of the collections of the former Musée d'Antiquités de l'Université de Gand, the oldest in Flanders, Belgium, founded in I825. At that time, collecting "exotic" objects was driven by the Western fascination with the so-called "lost cultures of the world" and, from then on, generations of professors contributed to the development of the universal collection of the Musée d'Antiquités (Vandenhoute and Burssens 1986:5-35).

With the First World War, interest in the study of these 'lost cultures' decreased considerably. After the war, a group of experts was formed in Brussels with the aim of reviving academic interest in the collections. One of them was J. S. Harry Hirtzel, who published the catalog of the new Section of American 
Archeology of the Royal Museums of the Cinquantenaire in Brussels. On the occasion of the inauguration of this section, in 1923, the exhibition, "PreColumbian Antiquities" was organized, and the Maya pottery of the Musée d'Antiquités drew the admiration of scholars and experts. In 1925, Hirtzel presented the Maya collection during the International Congress of Americanists in Gothenburg. He also published an article with the first photographs of a small selection of artifacts (Hirtzel 1925:668-672).

The collection was shown again in 1928, during the exhibition "Ancient Arts of America" at the Palais du Louvre in Paris. On this occasion, curator Jos Maertens de Noordhout (1930:5) wrote: "This Maya collection is unique, no other museum in Europe has such representative pieces, and Ghent University can be proud of it." He described the objects based on data from older inventory books, one of which - perhaps the most important - was destroyed by fire during the First World War. His publication includes the only surviving field notes from Georges Léger about his excavations in Verapaz (Maertens de Noordhout I930:3-I4).

In 1934, M. Louise Baker, a renowned American illustrator of archaeological artifacts who was working in Germany, had to leave that country for The Netherlands on the eve of the Second World War. She wrote in her letter of 30 July: "Although there was not much Maya pottery to be painted, I did find vessels worthy of painting at the University of Ghent. Their museum has an unusual collection of little covered pots of Maya origin. It is a group of vessels with effigy heads upon the lids, a type unique in Mayan pottery. Many of the pots are not mated, as to lids and vase, but I made color drawings of five of the best and have color photos of the others. We have nothing like them at the Museum." Her paintings were published in 1943 by the Museum of the University of Pennsylvania (Danien 2004:20-35). ${ }^{3}$

More than 3 decades later, in 1968, on the initiative of Prof. Pieter Jan Vandenhoute, the successor of Prof. Frans Olbrechts, ${ }^{4}$ the ethnographic collections of the University of Ghent, still packed in boxes and crates, were finally moved to the Hoger Instituut voor Kunstgeschiedenis en Oudheidkunde (Blandijnberg) and were presented in a proper museum display. In 2002, the collections were moved to the former $\mathrm{I}^{\text {th }}$ century Dominican monastery, property of the university, known as Het Pand, where the Maya collection, among others, was kept until today (Pauline Van der Zee, personal communication, 2019).

In 20I6, curator Pauline Van der Zee asked me to document the Maya collection on the occasion of the opening of a new university museum, the Gents Universiteitsmuseum (GUM) in 2020, at Campus Ledeganck, where part of the university's scientific collections will be housed. At that time, there was little information available about the origin or archaeological context from which the objects came, except for the measurements and description of the artifacts from the registration cards, the publications mentioned before, and that from Vandenhoute and Burssens (1968). The starting point for the search was a small note with the only indication on the provenance of the artifacts: "Finca Chichen, Santa Cruz, Alta Verapaz." 


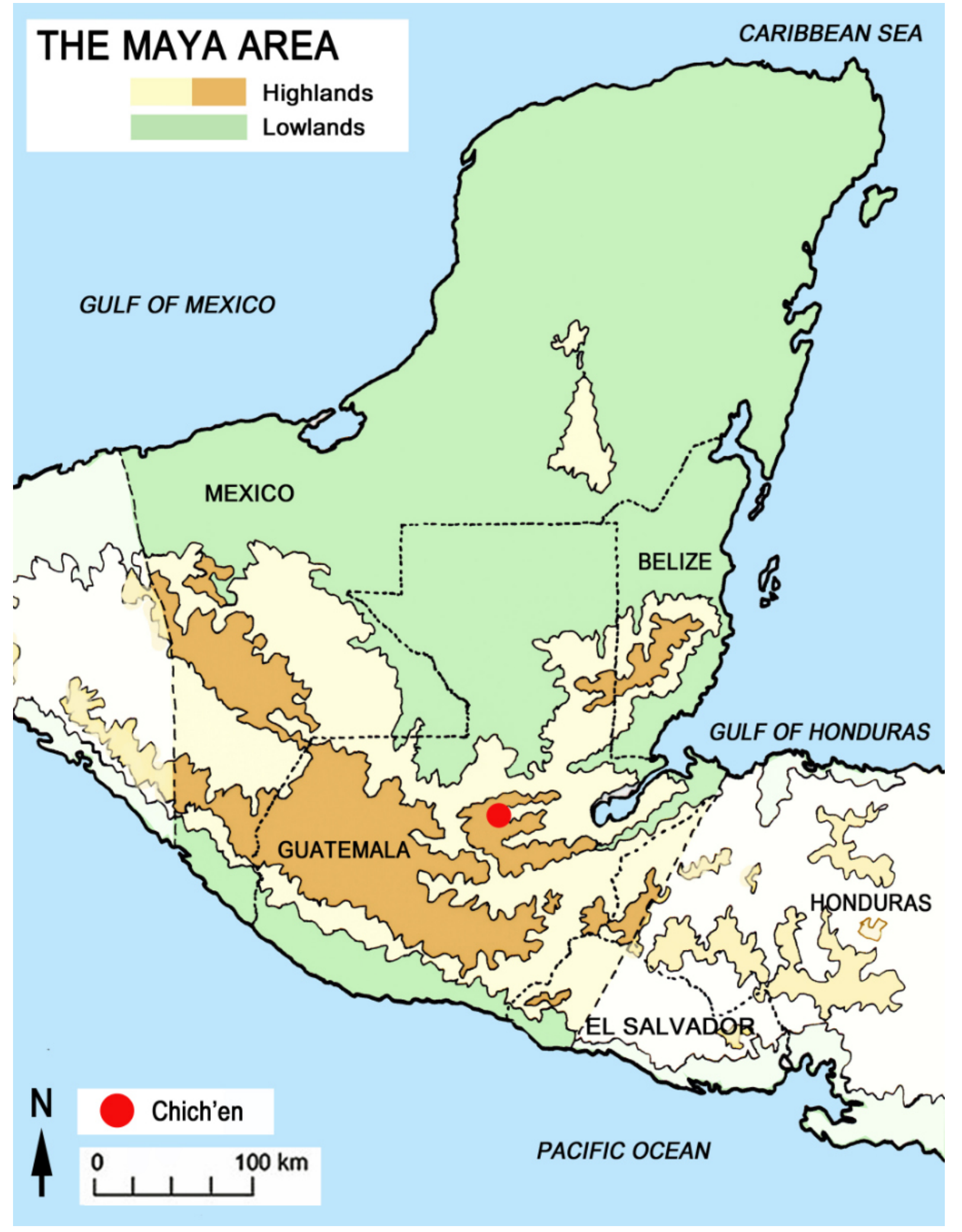

Figure 1. The Maya area, and location of Chich'en. 
Figure 2. Chich'en valley, Cobán, Alta Verapaz.

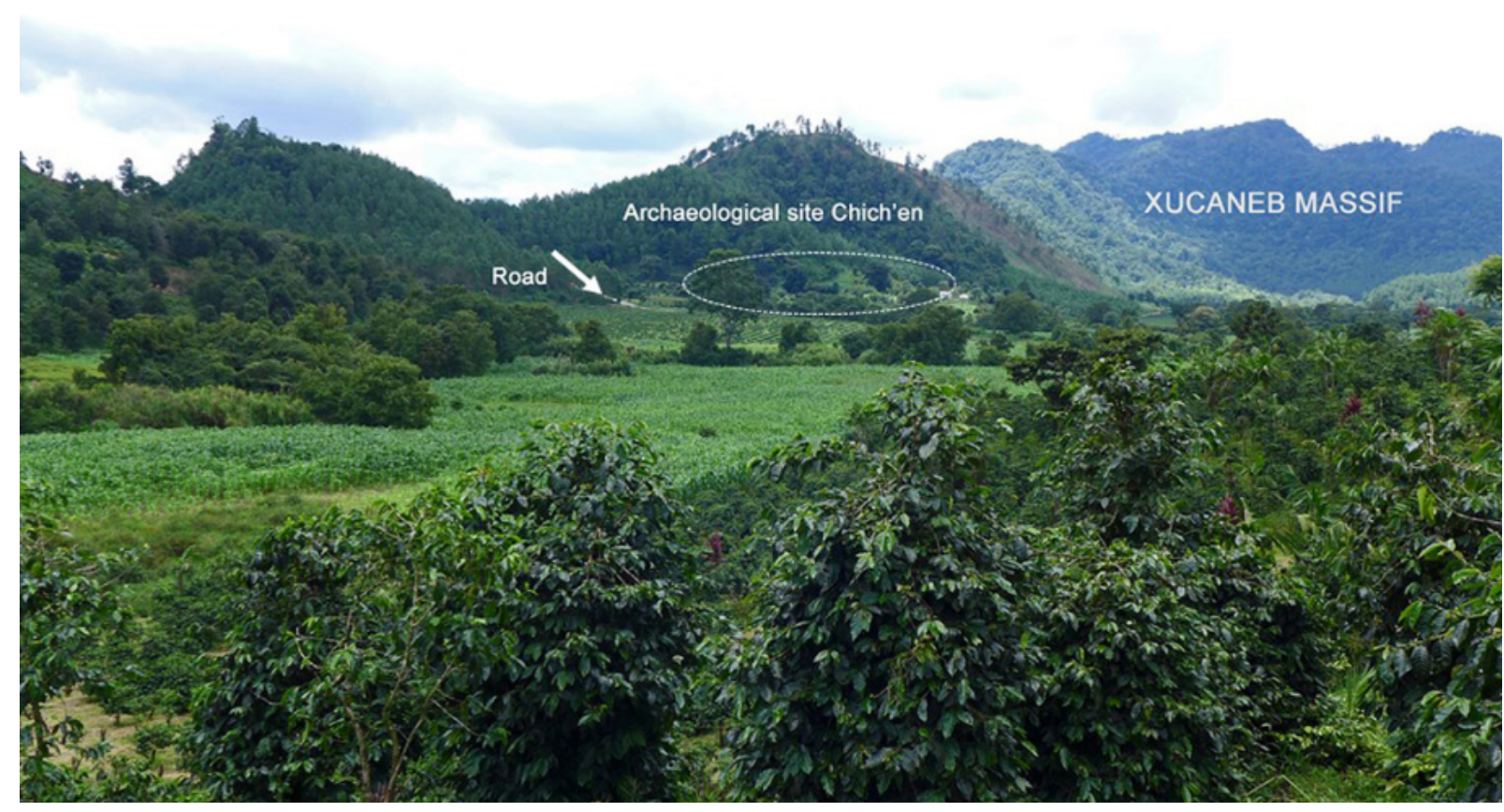




\section{SETTLEMENT PATTERNS OF THE GUATEMALAN HIGHLANDS}

\footnotetext{
tephan F. De Borhegyi (1965:59-75), ${ }^{5}$ studied the changes in settlement patterns in the Guatemalan Highlands spanning a period of more than two millennia. Here follows a summary of the developments in different time periods proposed by De Borhegyi:
}

Man has shaped his environment to his needs despite geographical and climatic limitations of landscape. With dwellings and temporary or permanent settlements, he has gradually changed and controlled his surroundings. Through a study or survey of the nature, size, extent, and limitations of ancient dwellings and settlements unearthed in excavations, archaeologists can reconstruct with reasonable accuracy something of the type and complexity of the cultural institutions which once governed the life of these communities. The settlements reflect such things as social distinctions, means of social control, and relative size and density of population. They also indicate subsistence activities, availability of food supply, and degree of economic specialization.

\section{Early or "Village" Formative Period (1500-600 BC)}

Preclassic sites, or "farming villages," were settled mostly in open valleys, where arable lands were available with rich soils and climatic conditions favorable for small-scale milpa agriculture, with permanent supply of water and fuel, as well as game, fish and fruit. These settlements were probably composed of rectangular thatch-roofed huts with adobe or stone walls and may have had a covered porch. They were built on low platform mounds made of earth or stone. Some of them may have contained family altars and shrines. Even as early as Early Preclassic times these structures were much like the hamlets of the present-day Maya of the Highlands (Wauchope, I938 cited in De Borhegyi, 1965). A main reason to settle was the proximity to such sacred localities or cult objects as mountains, hills, boulders, hot or cold springs, caves, lakes, and water holes (Figure 2).

\section{Middle and Late Preclassic period (600 BC to AD 300)}

In contrast to the haphazardly laid out hamlets of the earlier period, the organized planning of the plazas and surrounding mounds shows the definite concept of a ceremonial precinct, a sacred burial enclosure, from which village life was apparently excluded. The scattered house clusters or "farming villages" remained much the same as in the former period but, gradually, these previously autonomous village clusters may have become subsidiary to a major ceremonial or "worship" center. It can be assumed that each major worship center was built, supported, and maintained 
by the communal efforts of several dispersed satellite villages and hamlets. In this period, the villagers remained rural residents although they became participants in the life of the ceremonial center, with the burial center and its plaza serving as the functional nucleus or "worship center" for the several outlying farming villages. By the end of the Late Preclassic period, there is evidence of a steady growth of settlements in the Guatemalan highlands. Apparently, they reached the peak of their population and prosperity between $300 \mathrm{BC}$ and $300 \mathrm{AD}$. There was a great growth in certain important ceremonial centers in Alta Verapaz, which remained open and undefended as before; among them, Chich'en, Santa Elena and Chinchilla (A.L. Smith, I955, cited in De Borhegyi, 1965).

One may wonder what caused the sudden upsurge of monumental architectural activities, the building of large and tall pyramidal temple and burial mounds, during this period. No doubt, sedentary life gave opportunities for improved housing accommodation and paved the way for architecture (Figures 3 and 4 ). It can be assumed that the Preclassic farmers must have found new ways to intensify their food collection and production, probably by introducing crop rotation, irrigation, or terrace agriculture. They must also have found better ways to preserve and store surplus food and other commodities.

Figure 3. Burial mound (Structure 2), Chich'en, view to the northeast. In the background, the hillside where the site lies. The Mestela river flows nearby (treeline, midden).

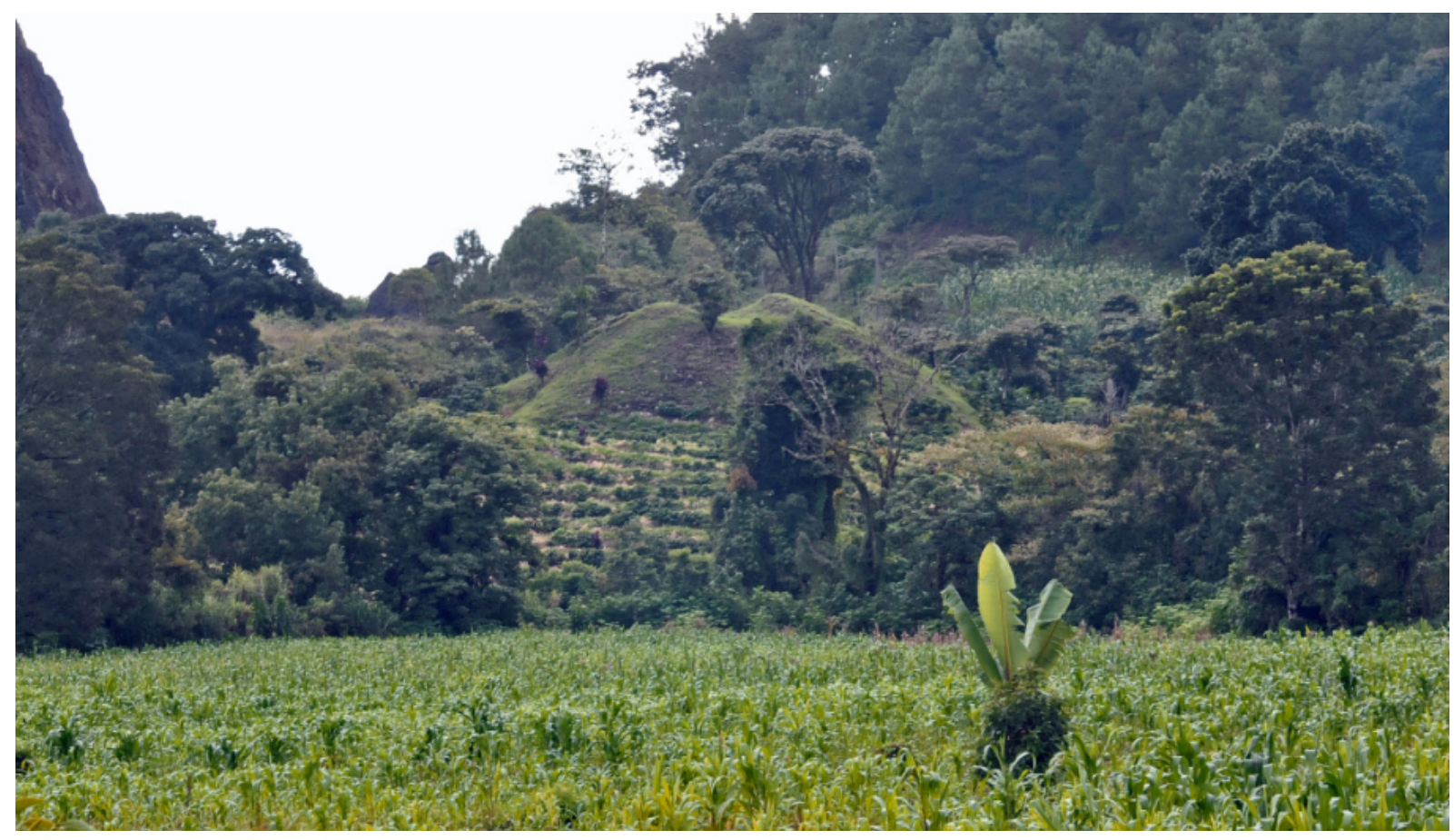




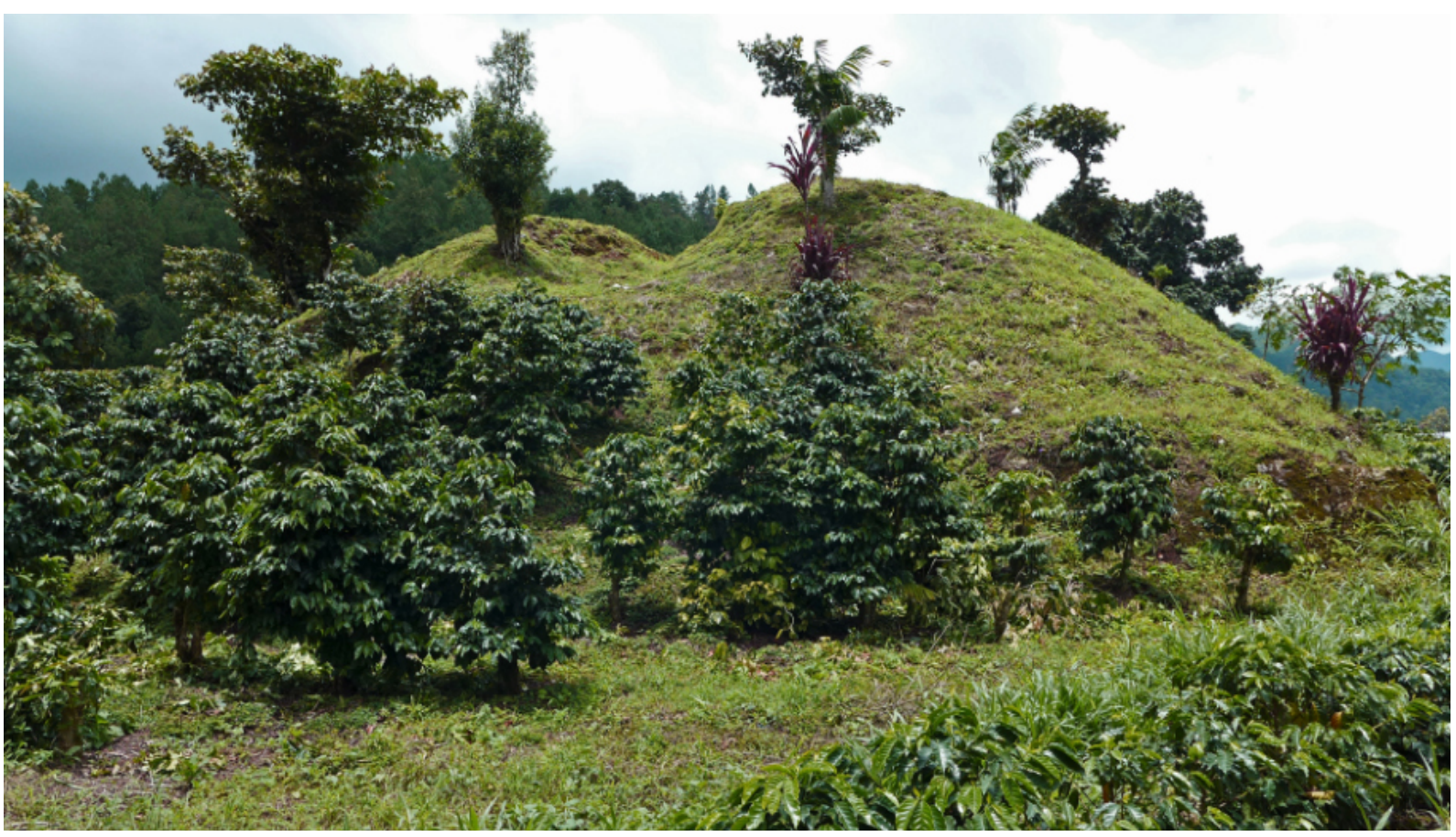

Figure 4. Burial mound (Structure 2), Chich'en.

Innovations in agricultural practices, in turn, permitted the redistribution of human energy and the withdrawal of certain individuals from direct foodproducing activities, making possible the existence of part- and full-time nonagricultural specialists. Simultaneously, village specialization in certain crafts and crops, created a need for organized trade relationships with neighboring settlements. The exchange of commodities was accompanied by an exchange of ideas. Eventually the newly found bonds were expressed at common places of worship and market activities which were probably located in most cases within easy reach of the supporting villages, near sacred places or cult objects.

\section{Early and Late Classic Periods (AD 300 - 1000) Rise, culmination, and fall of the theocracy}

The Classic period seems to have followed the cultural and settlement pattern trends established during the Late Preclassic. Settlements were still undefended and spread out on the open valley floors and plateaus and near riverbeds. There seems to have been a growing tendency toward the establishment of more centralized locations and court assemblages for ceremonial observances, market gatherings, and perhaps for the first time, for ritual ballgames in ballcourts open at both ends and generally with sloping side walls (see figure 19). Many of the new ideas of this period may have been the result of foreign religious, architectural, and artistic concepts emanating in all probability from Teotihuacan, Mexico. These ideas apparently spread throughout Mesoamerica and were felt everywhere with varying degrees of intensity. Some of them were probably carried by itinerant merchants who dispersed them along with trade goods. Others may have been the result of actual foreign domination. 


\section{Late Classic (AD 700-1000)}

Toward the end of the period in the Central and Western Highlands and in the hilly middle country rebuilding activities seem to have slowed down. Instead of the burial and temple mounds, low elongated platform mounds were arranged around smaller tightly enclosed plazas and rectangular ballcourts. By this time, however, the ballcourts were closed at both ends (Shook, 1952b, Shook and Proskouriakoff, 1956; A.L. Smith 1955, cited in De Borhegyi, 1965). It is quite possible that by the end of this period, some of the minor ceremonial centers (especially those of the hillslopes) were used more and more for habitation, localized market gatherings, and for secularized ballgame activities, rather than for burial and ceremonial purposes. The Preclassic "grave-oriented" society became by Late Classic times more and more secularized, and the recently emerged warrior, merchant, and artisan elements became increasingly powerful. Mass-produced mold-made pottery vessels and figurines were turned out in ever-increasing numbers to meet the needs of a growing population (Figure 5).
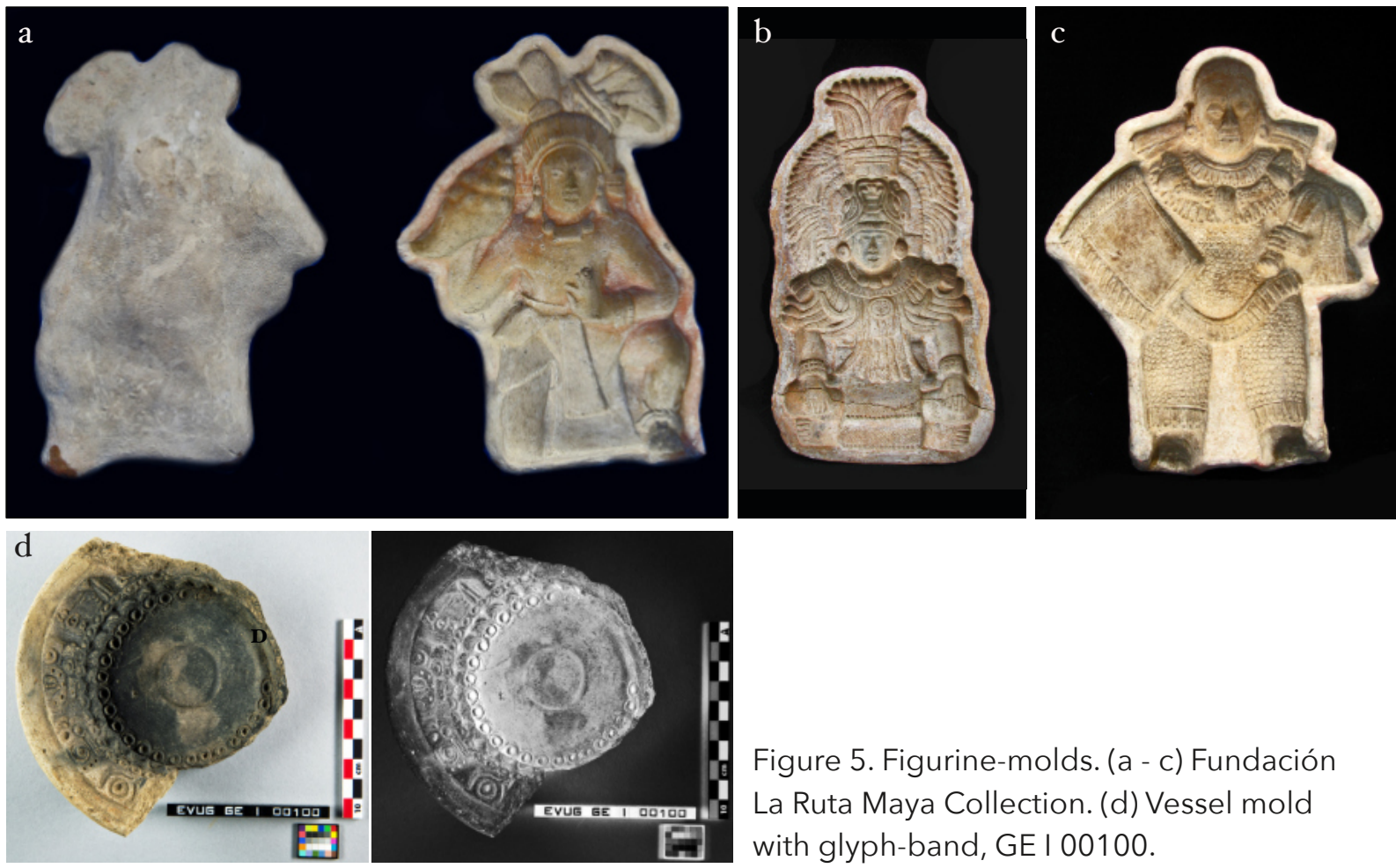

Figure 5. Figurine-molds. (a - c) Fundación

La Ruta Maya Collection. (d) Vessel mold with glyph-band, GE I 00100.

It would almost seem that the major ceremonial centers lost out in prosperity and popularity to the mushrooming localized minor centers. This change may reflect a weakening of the divine power of the major gods and a growing pantheon with many newly emerged but powerful lesser gods. However, it is more likely that the constant building activities forced the expanding population to move farther and farther from the valley sites in search of unoccupied farmlands. Eventually these farm plots became so distant from the original settlement that commuting became impractical and new centers were established locally. The smaller settlements would 
unquestionably have desired independent ceremonial and political status. This theory may also help to clarify the most startling settlement phenomenon in Middle American prehistory: the apparent abandonment of the Maya ceremonial centers by the end of the Late Classic period. However in the Guatemalan Highlands and in Chiapas, Mexico, the abandonment of the ceremonial centers could have been influenced by such factors as soil exhaustion, climatic change, or epidemic. The move away from the valley sites and onto the hilltops may have been further accelerated for reasons of self-defense against hostile Mexican and greedy neighboring groups. By the end of this period the ceremonial centers were almost totally abandoned and left to decay (Figure 6).

Figure 6. Topographical and archaeological chart of the area surveyed by C. Arnauld (1986).

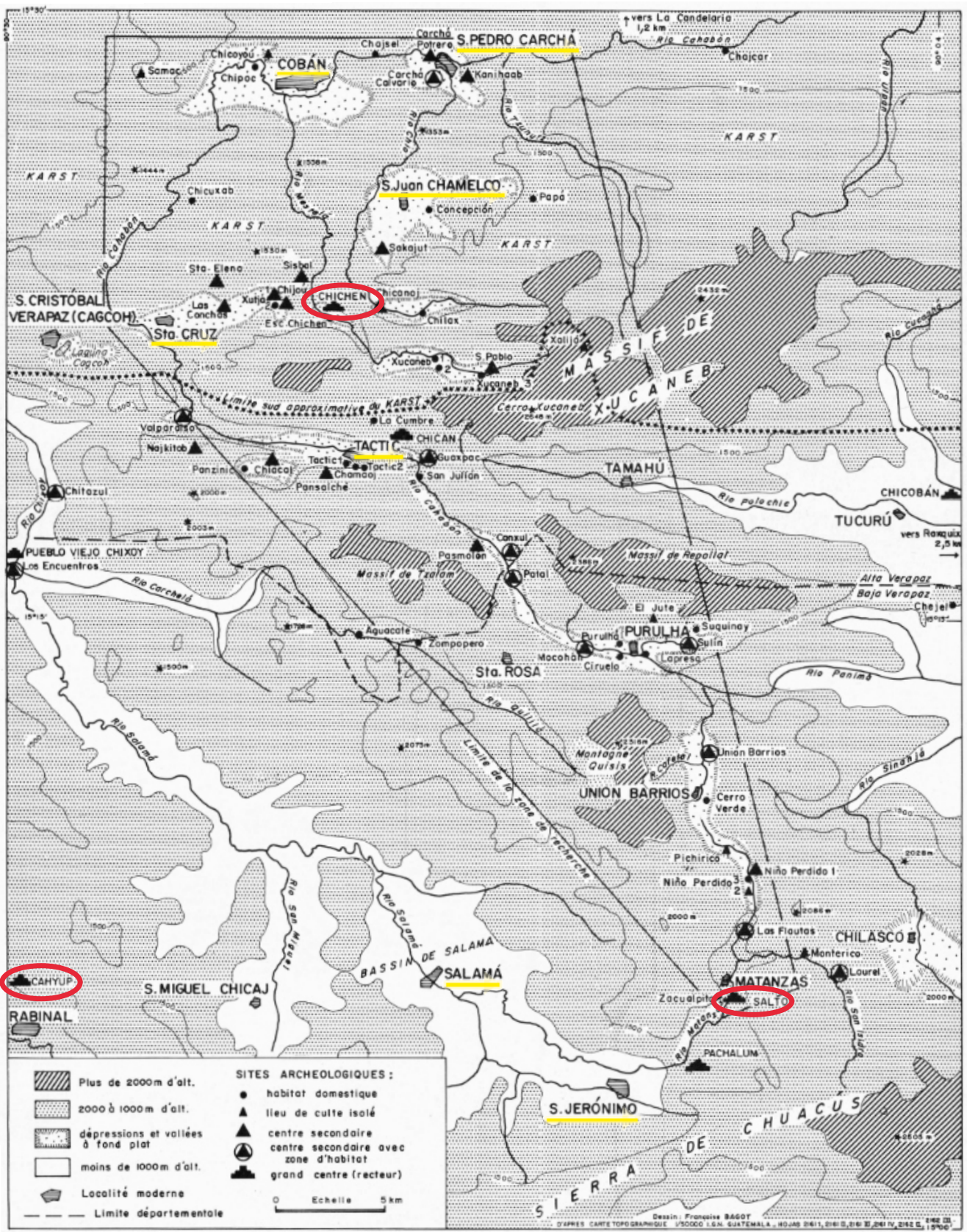




\section{Postclassic and Protohistoric Period (AD 1000 - 1200) Rise of the Militaristic Society}

Most settlements were moved or newly established on more easily defensible and strategically located hilltops, or isolated mountaintops. Nevertheless, the surveys of A.L. Smith (1955) clearly indicated that several valley sites such as Chich'en (Figure 7) and Chicuxab, in the Cobán area of Alta Verapaz, continued to be occupied during Postclassic (AD Iooo-ı20o) and even in Protohistoric times (AD I200 - 1524). The shift from the undefended valley sites to defensive hilltop positions can probably be explained as a breakdown of the former "sacred" society into smaller, warring "nationality" groups, each craving independence and selfgovernment. We may safely assume that the formation of the K'iche', Kaqchikel, Tz'utujil, and Mam national "kingdoms" dates to this period. There was a need for easily defensible and strategically located intermediate and hilltop locations, in the proximity of trade and pilgrimage routes ("roadside" hamlets and centers) and agricultural areas, as well as water supply in case of prolonged warfare and hilltop isolation. By that time, a secular administrative and military bureaucracy developed, and the migration and peregrinations of militant foreign groups (Toltecs, Nahuas, Pipils), increased. The Protohistoric defensive sites were situated on artificially leveled hilltops or tongues of land surrounded by deep ravines. Skillfully constructed drainage systems suggest that the new settlements were designed for more or less permanent habitation, unlike the worship centers of previous periods. These signs indicate a growing emphasis on city living and secularization.

Figure 7(a). View of the main structures of Chich'en from the road. In the background, the west end of the Xucaneb massif. The highest peak on the left is Chichen Mountain.

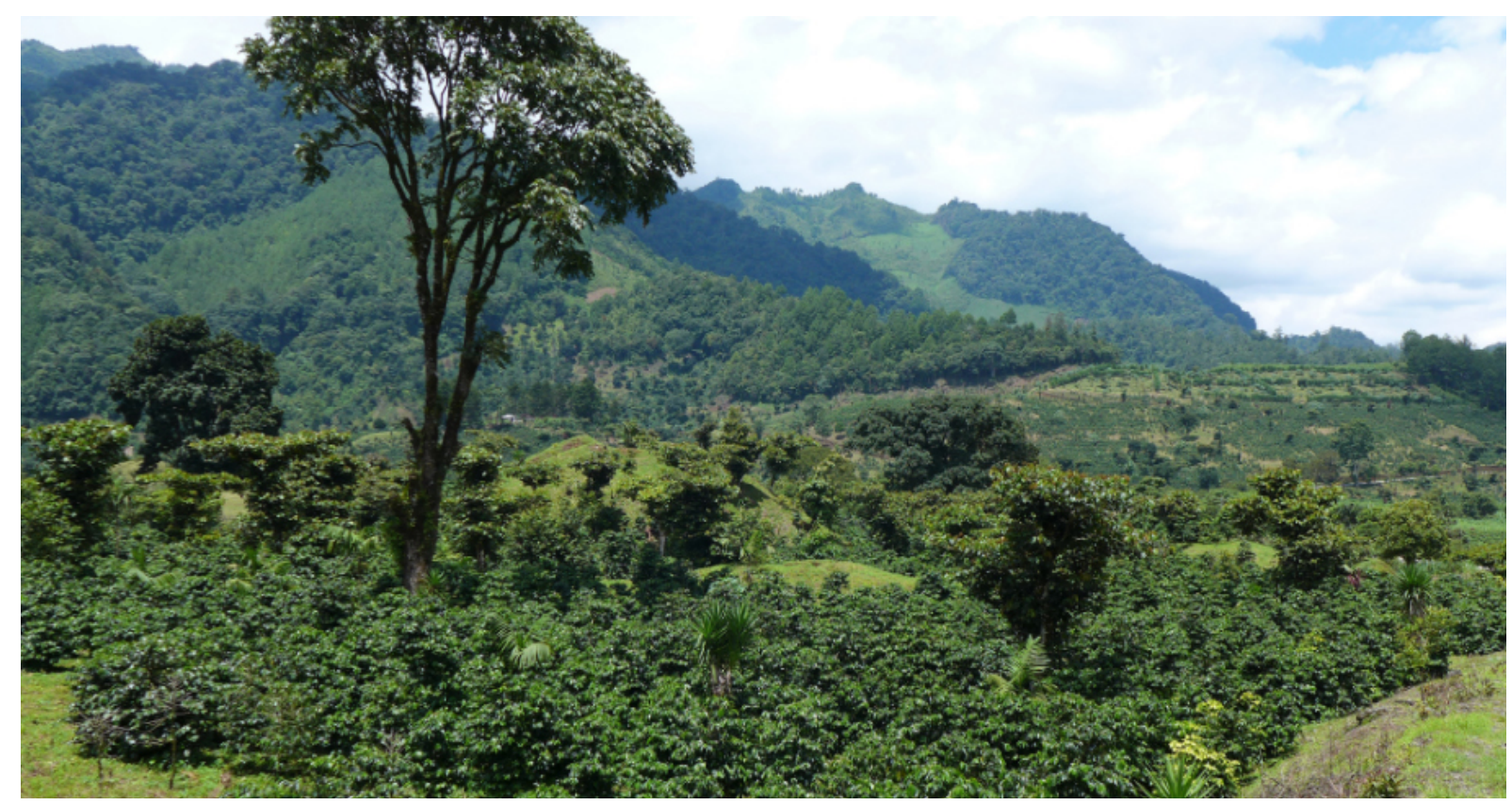


The formerly sacred ballcourts were built with side benches and in the shape of the letter I (sunken courts) and may have been used to a great extent for entertainment, while the sacred enclosures or plazas frequently became the scene of secular market gatherings and dance performances. There was a change from inhumation to cremation practices (less need for impressive and large burial mounds). Trade and specialization were extensive and widespread. During this period, a prosperous class or guild of merchants and artisans came into being, enjoying the benefits of a concentrated surplus of wealth and social standing. It must be understood, however, that these hilltop settlements could never have accommodated large aggregations of people for any extended period. The bulk of the population, as in former times, probably continued to live in nearby hamlets or satellite farming villages.

\section{Protohistoric, AD 1200 - 1524}

The greatest change in the settlement pattern of this period was not so much in its layout but in its emphasis and function. Whereas in earlier periods the ceremonial centers served as focus for pilgrimage and religious activities, during the protohistoric period it is probable that the sites took on more and more the character of a fortress. Used in time of peace for festival, political, and market activities, Maya hilltop settlement became in time of war a refuge for the neighboring farmers and merchants and served as a fortress for the militant warrior class and their lords (A. L. Smith I955:48-53). An excellent example of such a defensive hilltop site is Cahyup in the Rabinal Valley, Baja Verapaz (Figures 8 and 9).

Like the Aztecs of Mexico, the K'iche' and Kaqchikel Maya nations of highland Guatemala became in Protohistoric times sizable militant empires with expansionistic tendencies by means of military conquests, economic penetration, and colonization. Their expansion was cut short only by invaders from Spain in 1524 (De Borhegyi 1965:59-75).

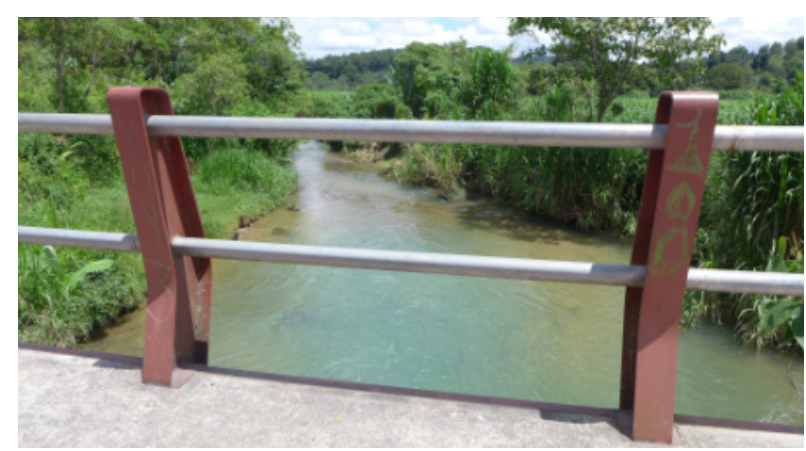

Fig. 7 (b)

The Mestelá river seen from the bridge. See also figure 12. 


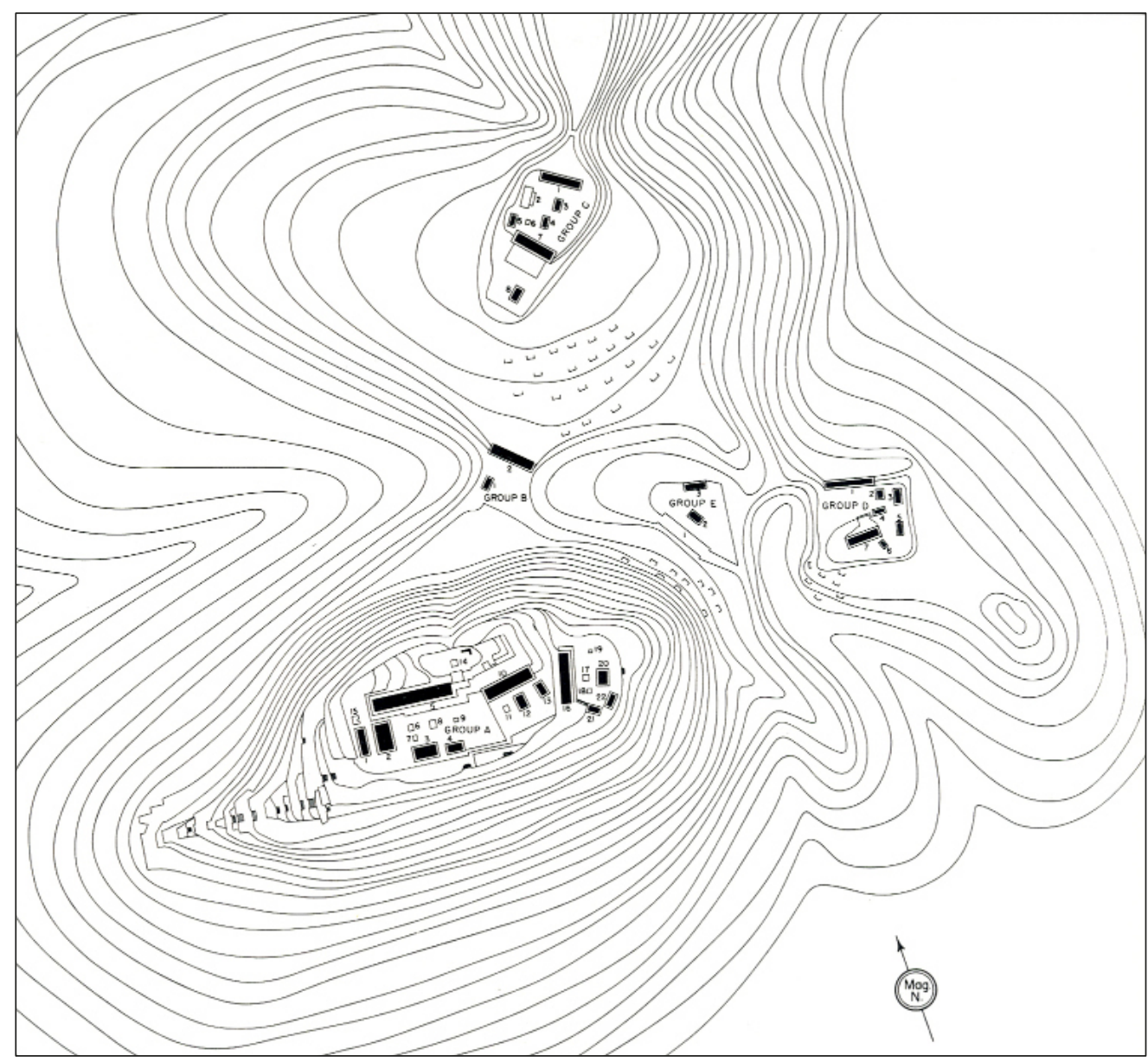

Figure 8. Cahyup archaeological site, Baja Verapaz.

Figure 9. Cahyup is still a ceremonial place.

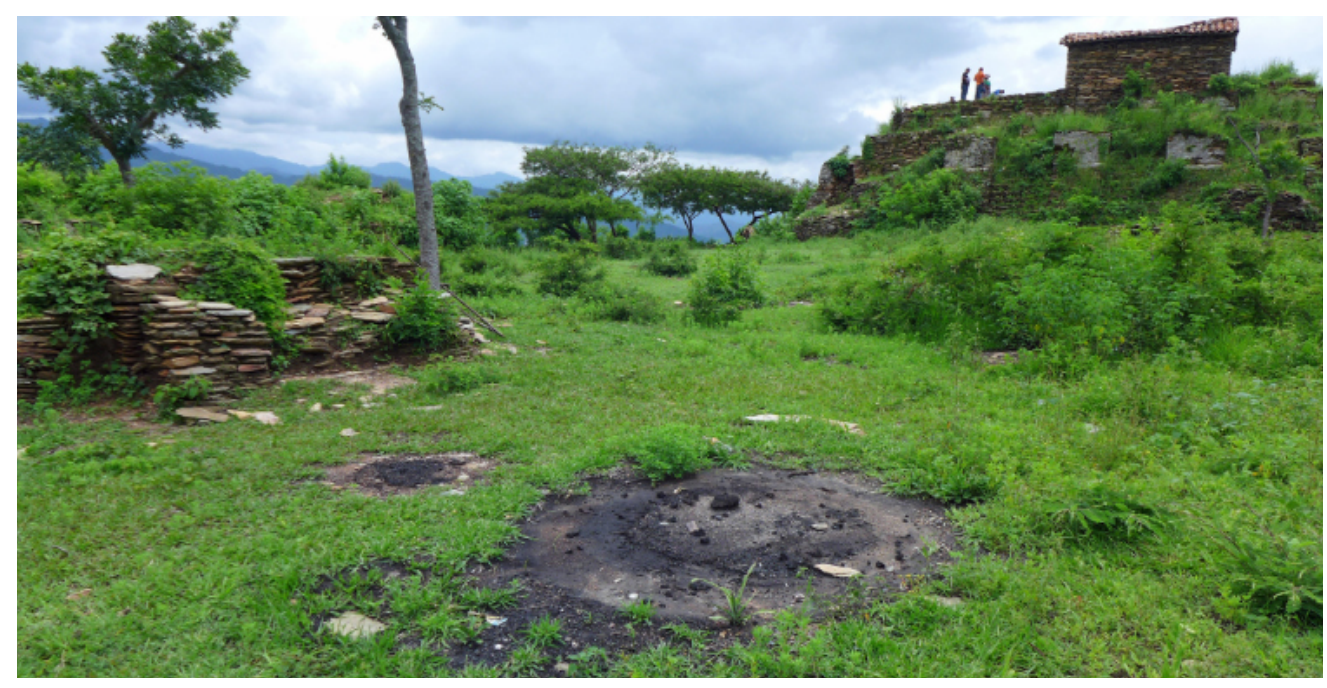




\section{ARCHAEOLOGICAL SITE}

\section{ARCHAEOLOGICAL SURVEYS OF CHICH'EN}

\section{4}

Karl Sapper (I895:I8) mentions the settlements in the Q'eqchi' area where Germans, in I894, were carrying out excavations. He points out that, by that time, the Belgian Georges Léger was excavating in Chich'en (see also Maertens de Noordhout 1930:3-I4).

\section{9}

During the I940's, the American, A. Ledyard Smith, conducted an extensive archaeological reconnaissance in Central Guatemala (Carnegie Institution of Washington). The area investigated included the Departments of Huehuetenango, El Quiché, Baja Verapaz, Alta Verapaz and Chimaltenango, a region densely populated over a long period before the Spanish invasion. This region was important because it covered one of the main north-south routes of migration and trade, and because of its position between rivers and valleys, connecting it with the Lowlands to the north, where the ancient Maya reached their cultural height, and the fertile and densely populated slope leading down to the Pacific.

In April I949, A. L. Smith spent three days at the ruins of Chich'en, mapping, photographing, making a rough sketch plan, and collecting pottery from the surface and from various pits. This was the first formal archaeological survey conducted at the site. Smith also published the first maps and two photographs of the west ballcourt. ${ }^{6}$ The pottery recovered from pits, dug in three mounds, from the trench across the center of the ballcourt alley, and from the surface, shows a long period of occupation, the earliest being Late Preclassic, and the latest the Late Postclassic (A. L. Smith I955:1; 6o-62; figs. 38, 39 and I34).

Table 1. Chronology and ceramic phases of Western Alta Verapaz.

\begin{tabular}{|c|c|c|}
\hline PERIOD & DATE & CERAMIC PHASE \\
\hline Late Postclassic & 1540 & Chicán \\
\hline Early Postclassic & 1250 & Samac \\
\hline Late Classic & 1000 & Cobán 2 \\
\hline Early Classic & 700 & Cobán 1 \\
\hline Late Preclassic & 500 AD & Carchá \\
\hline
\end{tabular}




\section{$1974-1976$}

Between 1974 and 1976, the French archeologist, M. Charlotte Arnauld (1986) carried out the second archaeological survey in Alta Verapaz (Mission Archéologique et Ethnologique Française au Mexique /Instituto de Antropología e Historia de Guatemala).

The purpose of her research was to reconstruct and analyze the regional settlement patterns, especially during the Late Classic period, when the contacts with the Lowlands seem to have been most intensive. The research also focused on the Preclassic settlement, although only at an exploratory level, and upon the local socio-political organization during the Late Postclassic. Arnauld (I978:4I-62) also studied the habitat and the society of Verapaz during the contact period and the arrival of Dominican friars in the area in $1535^{-} 1540$, based on the ethnohistorical sources available for Alta Verapaz.

The survey and the excavations were conducted in the south-western zone of Alta Verapaz $\left(665 \mathrm{~km}^{2}\right)$, which extends from the Valley of San Jerónimo to the south and Cobán and San Pedro Carchá to the north. This zone can be divided into two physiographic districts. The northern side of the limestone Sierra de Alta Verapaz is characterized by sinks, ravines, and underground streams that gradually slope down toward the Lowlands. The hills surround small, flatbottomed basins with fertile soil (average altitude of $1200 \mathrm{~m}$ ). To the south, the higher ranges of the Sierra ( $1500-2600 \mathrm{~m}$ ) are carved out by deep narrow valleys. On the slopes, the easily eroded soils are moderately fertile. Annual rainfall, which is abundant in the northern district, decreases slightly from north to south. To the extreme south of the zone, the Sierra borders on the metamorphic ranges of the Sierra de Chuacús in Baja Verapaz (Figure 6).

An intensive survey was conducted in the areas most favorable to human settlement and farming, such as the small basins and the valleys. 6I sites were surveyed, adding 6 sites formally reported in previous investigations. According to the functional typology based on morphological traits, these sites comprised small residential hamlets (28 sites), isolated ritual loci (8), secondary centers (26), each with one formal public plaza, and major centers (5) with multiple public plazas, among them Chich'en. Pottery samples collected by Smith (1955) and by Arnauld (1986) are kept at the National Museum of Archaeology and Ethnology of Guatemala.

The Xucaneb Massif, view from Tactíc.

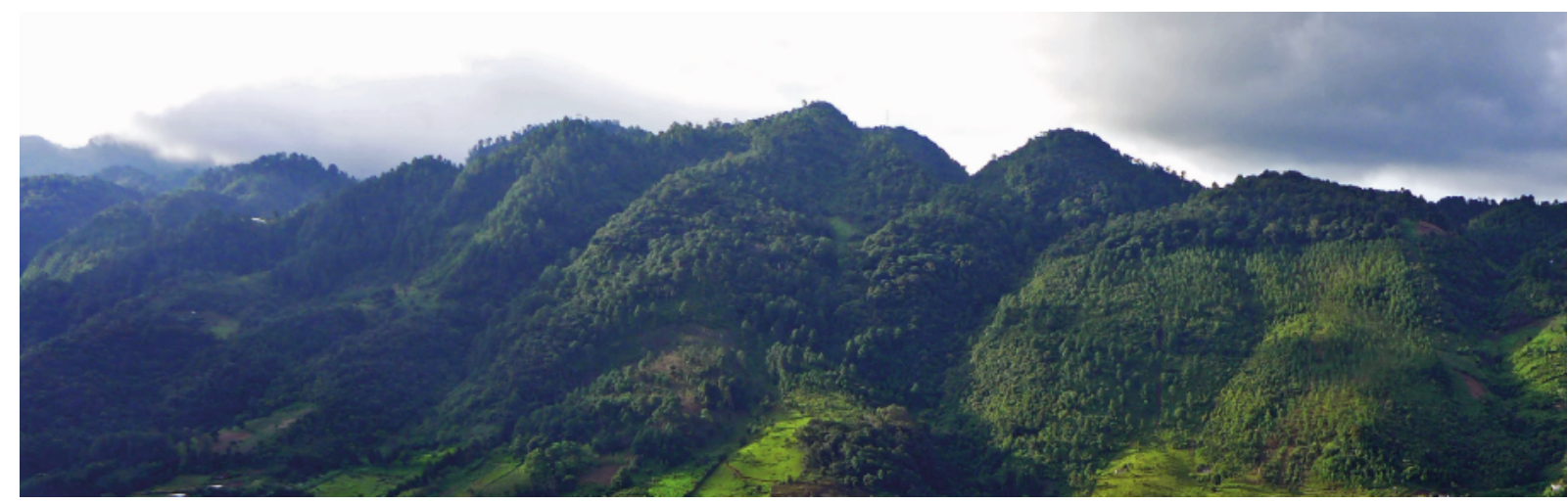




\section{GEOGRAPHICAL SETTING}

The archaeological site lies in the karstic area of Alta Verapaz, at an altitude of I $420 \mathrm{~m}$, on a plateau between the modern cities of Cobán to the north, Tactic to the south, San Juan Chamelco to the northeast, and Santa Cruz Verapaz to the west (Figure Io).

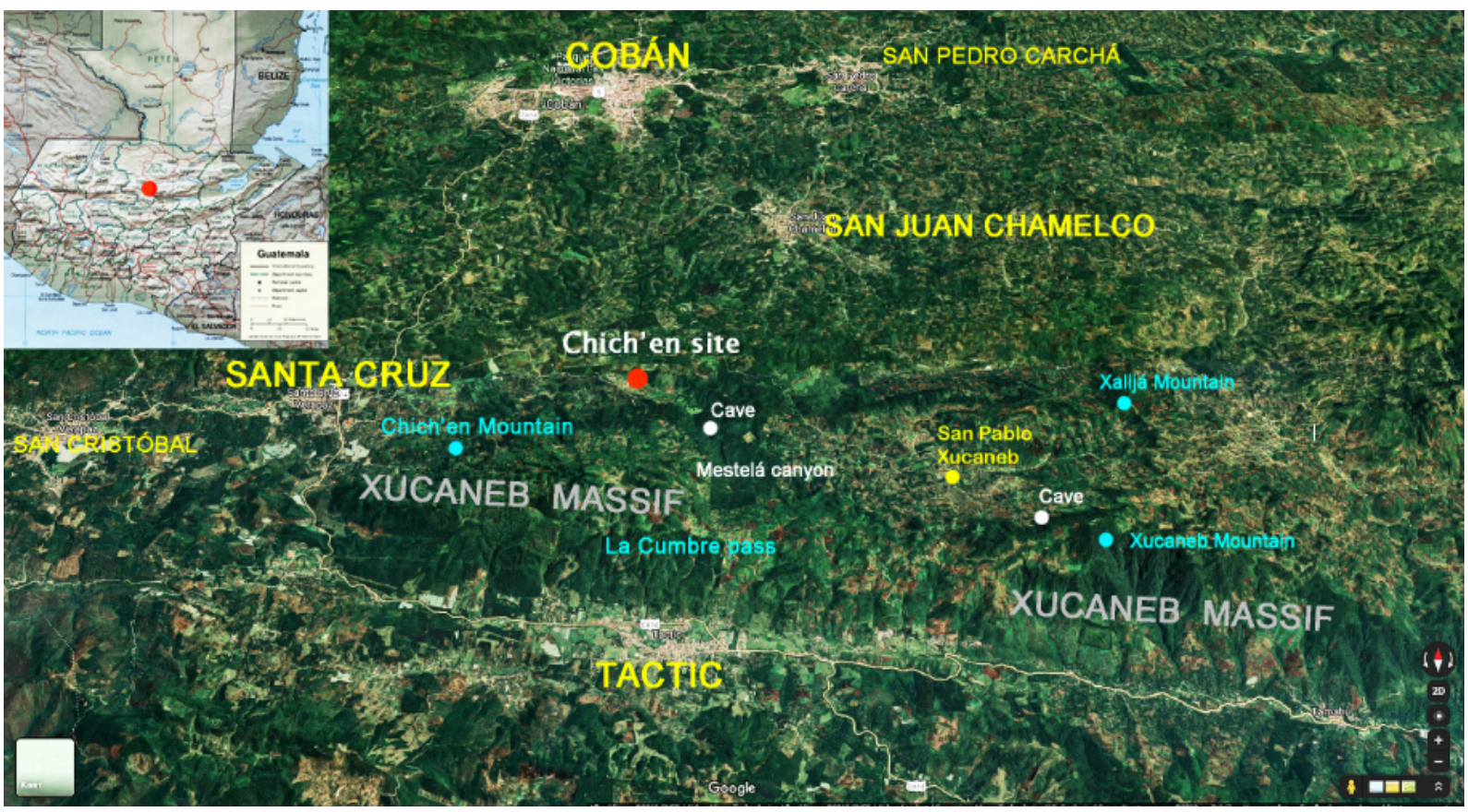

Figure 10. Location of the archaeological site Chich'en.

Chich'en, the most important site of the Cobán plateau is located in Finca Chichen, a large private coffee plantation named after Chichen Mountain (Smith 1955:6I). The site is settled on the slope of a hill in a small depression at the north base of Chichen Mountain, the second highest peak of the Xucaneb massif $(2223 \mathrm{~m})$, located at the western end of the massif. This mountain range extends to the southeast of the site and marks the southern limit of the Cobán plateau. It also defines the border between the Q'eqchi' speaking group to the north, and the Poqomchi' speaking group to the south.

The eastern end of the massif is marked by the grand Xucaneb Mountain, the highest elevation in Alta Verapaz $(2648 \mathrm{~m}$ ), and the most prominent landmark that can be seen from many vantage points, and it was undoubtedly used to mark the location of the plateau (Arnauld I986; Bassie-Sweet 20I9:I89). Río Chichen, ${ }^{7}$ currently named Río Mestelá, emerges in the Xucaneb massif, between Xalijá Mountain and Xucaneb Mountain, and flows west until it reaches the northeast slope of Chichen Mountain. At that point, the river turns north and enters a deep canyon, where it continues its journey underground. The river emerges again in a cave at the end of the canyon, close to the archaeological site and continues its journey to the north, bordering the hill where the site is settled (Figures II and I2).

The name Chich'en refers to this cave, and it is highly likely that the mountain and the archaeological site were named after the cave and this remarkable hydrographic phenomenon (Bassie-Sweet 2008:229). 


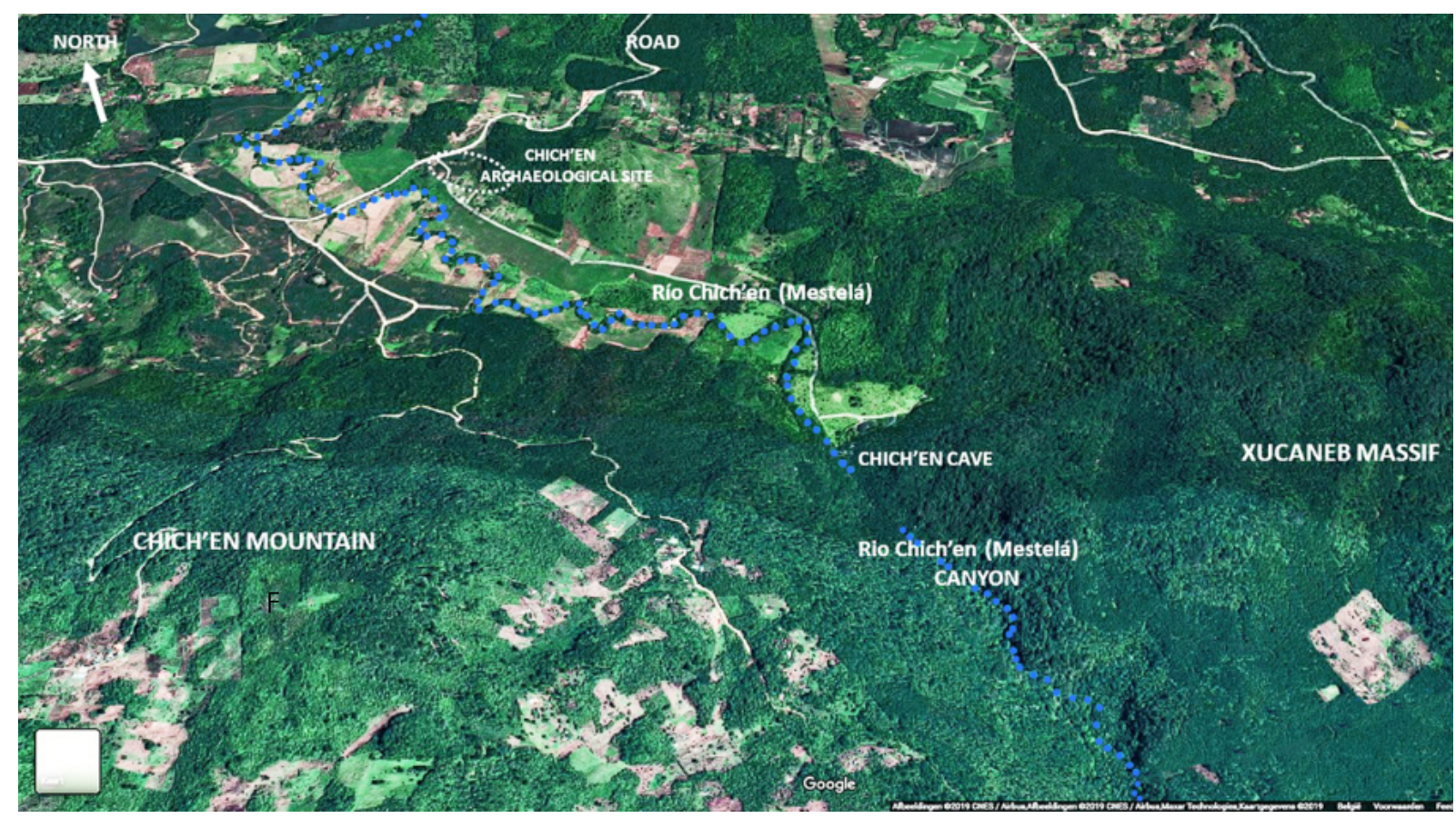

Figure 11. Chich'en valley and course of the Mestelá river from the Xucaneb Mountain to the north.

Figure 12. Aerial view of the site.

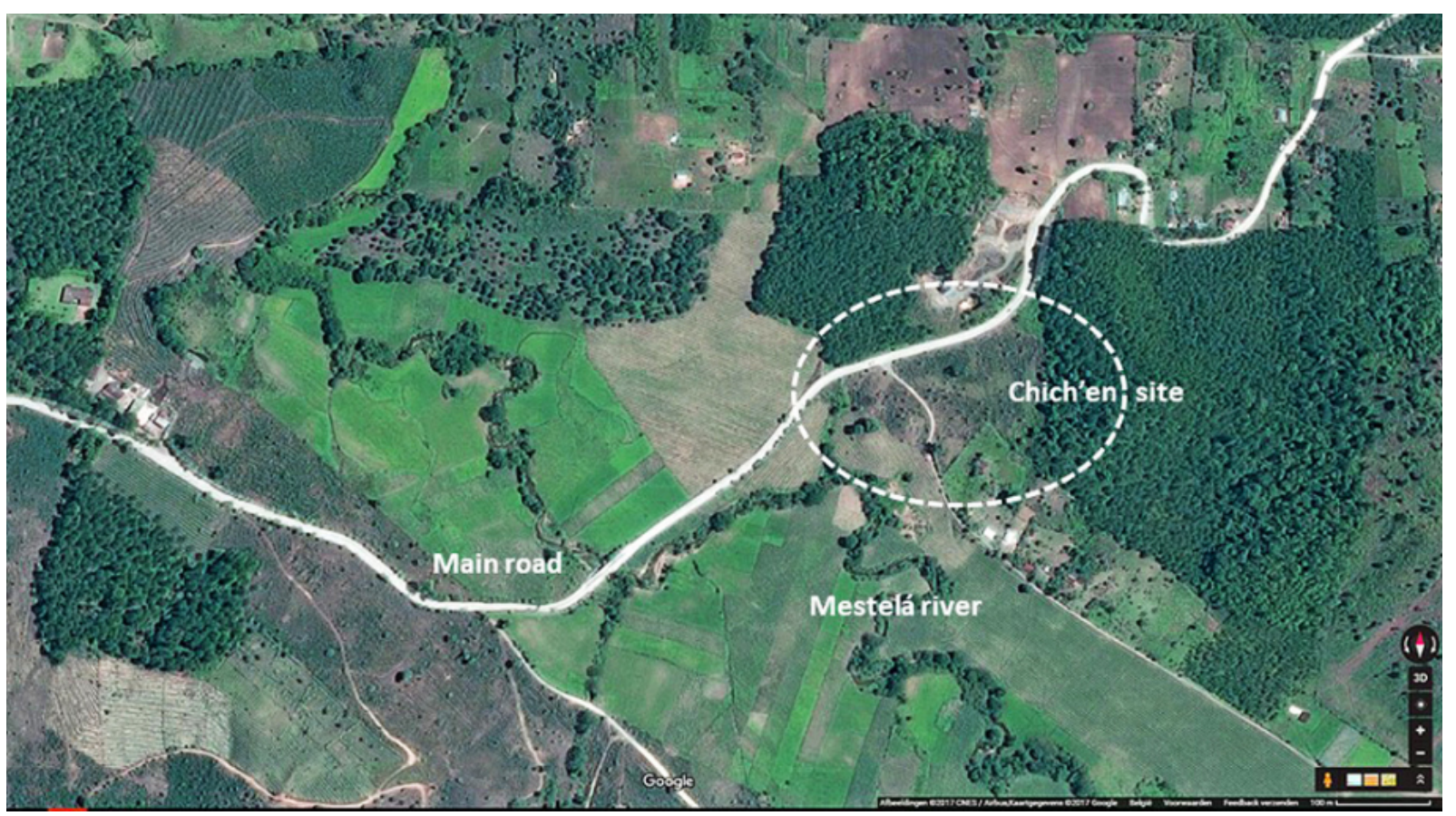




\section{SACRED LANDSCAPE}

Caves, hills, and mountains have undoubtedly been the most important geographic features of the landscape of the Maya region. This is especially the case in the karstic area of the southern Lowlands, with widespread caves formed by the erosive action of underground rivers. Their dramatic drip-water formations (stalactites and stalagmites), winding tunnels and huge caverns, stood as models for a set of ideas of great significance and played a major role in the ideology and world view of the Classic Maya. They have been the focus of ritual and community activities for centuries. Considered to be the home of ancestors and of deities associated with rain, wind, and maize, caves were a portal between the tangible human world and the invisible world of the gods. It was at this portal that the Maya performed their most sacred rituals (Bassie-Sweet I991:I25-I26; Vogt and Stuart 2005:155).

The sacred character of caves in Mesoamerica and the ceremonies performed inside, from the Preclassic through the Late Postclassic period, as well as the persistence of cave rituals until today, has been studied by many authors. ${ }^{8}$

Within the pattern of Maya and Mesoamerican beliefs, caves were perceived as places of political and community foundation. In Classic period inscriptions, the place-names and emblem glyphs of individual communities are identified with the names of nearby caves and their springs, as implied by the word ch'en or ch'en (Bassie-Sweet 1991:80; Vogt and Stuart 2005:I62-I63; Stuart 2015).

According to Tokovinine (2008:342-347), Maya place-names do not represent physical places directly, but point to associated features, like a mountain, a lake, a stream, or a kind of tree. Available Classic Maya narratives employ two spatial categories: - kab (literally "land" or "earth") and $c b^{\prime} e ' n$, literally "cave" or "canyon." Most Classic Maya place-names are associated with the $c b^{\prime} e$ 'n category, suggesting that these are the names of the places where gods and ancestors dwell, in "caves" and "canyons" - the holy grounds - or in temples. Together, "lands" and "caves" constitute the totality of spaces of one's political dominion. An emblem glyph or place-name is often related to the history of a royal family, which may or may not be associated with its current location. One's affiliation to a place or origin may pass through descent, but this does not imply that this place cannot be re-created in permanent architecture or in temporal installations, visited through pilgrimages, or evoked in any other way. In summary, Classic Maya written narratives place $c b^{\prime} e^{\prime} n$ at the heart of every community. Some Classic Maya royal families still lived by the $c b^{\prime} e$ ' $n$ where they thought their gods and ancestors lived thousands of years ago. Other dynasties traced their origins to faraway places or founded new royal courts at various locations but retained the association with the places where they came from.

Helmke and Kupprat (2017:95-98, 120) point out that some of the placenames incorporated in emblem glyphs refer to primordial locations and the settings of mythic events. Mythological places are often projected to the natural and artificial landscape, and in the same way, mythological narratives are created and modified to strengthen links with past events. The authors have shown that, 
at least in some cases, emblem glyphs are supernatural place-names. Some of them apparently refer to locations in the natural and physical world, while, in other cases, there is no record of events that have occurred in specific named places. Evidence from hieroglyphic texts on Late Classic ceramics suggests that the toponym Kanu'l, for example, names a cave with certain aquatic elements, where the defeat, death and resurrection of the Maize god took place. It is striking that, together with Kanu'l, other places are related to the resurrection of the Maize god, so the authors suspect that these place-names also have a mythological origin. According to them, it is important to underline that, when classifying a place-name as mythological, they do not exclude the possibility that it denominates one or several spaces in the physical landscape. ${ }^{9}$ It is clear that the proclamation and expression of a divine offspring, as well as the representation and personification of mythological and supernatural ancestors, were important strategies for the legitimation of socio-political power.

According to Brady and Ashmore (1999:132), Classic Maya oriented their architecture towards sacred places. This means that their civic centers were perceived and built within an orderly cosmic pattern. The appropriation of sacred features of the landscape in public architecture reflects a strategy to sanctify and legitimize the city and, by extension, its leaders. These acts 'humanize' the landscape, extracting its essential powers, transferring them to the field of human action and control. ${ }^{10}$

Most likely, the site of Chich'en owed its relevance, not only to the proximity of Xucaneb Mountain, but most importantly, to the proximity of Chichen Mountain, the Mestelá river canyon and the cave. This set of natural features forms a sacred landscape with great symbolic and religious value in which the founders of Chich'en settled, at the end of the Preclassic period (Figures II and $\mathrm{I}_{3}$ ).

Wilson (I993:I26-I28), suggests that, for contemporary Maya, especially in the case of the Q'eqchi'-Maya, the local community or municipality is the most noticeable basis for identity. The cornerstone of that identity is local geography. Community is imagined through its relationship with the sacred landscape embodied by the mountain spirits known as tzuultaq'a. They are the owners of the land and everything on its surface, including human sustenance. Each village is owned by an individual male or female mountain-spirit, residing in the nearest mountain with a cave, and tries to establish reciprocal relations with that particular tzuultaq'a.

Watanabe (I990:I3-150), notes that the landscapes of today's Maya communities are invariably structured through reciprocal relationships between community members and their categories of supernatural beings - ancestors, saints, and earth lords - associated with particular features of the natural and built environment. The symbolic domains of these entities frequently overlap. Ancestors and saints appear as protective guardians of social groups. Ancestors and earth lords often "own" the landscape and its produce. Saints and earth lords can be involved in witchcraft. However, the three categories also emphasize distinct aspects of social identity. Saints embody the ideas of proper society. 
Ancestors assure continuity in these ideas. Earth lords are characterized by moral intractability and represent social and physical boundaries of the community.

The deity known among the Q'eqchi' and Poqomchi' as "Señor Cerro-Valle", "Lord Mountain-Valley" or tzuultaq'a, tzuul meaning "hill or mountain" and taq'a "valley" is personified in each of the I3 sacred mountains of Verapaz, whose caves are considered the most appropriate place for the rites in honor of the tzuultaq'a that inhabits them. ${ }^{11}$ Xucaneb Mountain is the most sacred and revered of all. The term tzuultaq'a, in addition to referring to a geographical feature (the mountain), refers also to a deity with supernatural powers (Adams and Brady 2005:30I-327; Bassie-Sweet 2008:I8I; 2019:I-I2).

\section{NAME OF THE SITE}

Certainly, the place-name of the site derives from the Proto-Maya word for cave, ch'e'en or its cognates used in most Mayan languages (Bassie-Sweet 1991:80; Vogt and Stuart 2005:162-3; Stuart 2015). According to Van Akkeren (2012:71), the name to designate the archaeological site should be Chich'en, from the Ch'ol $c h i$ "in" and $c b^{\prime} e n$ or $c b^{\prime} e e n$, "cave", "In the Cave." In this report we will henceforward use the name proposed by Van Akkeren.

Figure 13. Chich'en Mountain-Valley.

View from the top of the burial mound (Structure 2), to the south.

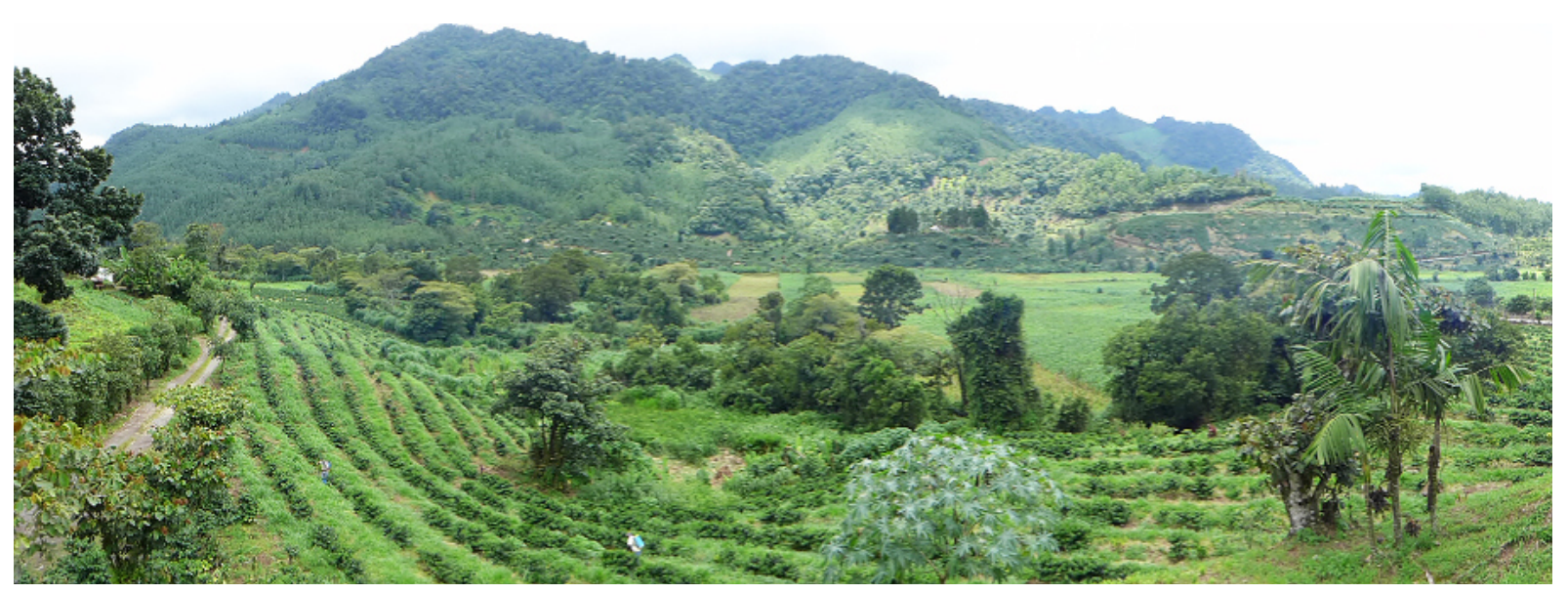




\section{ANCIENT TRADE ROUTES IN THE MAYA AREA}

During the Classic period, the dominant political entities in the Maya area and their respective representatives and allies competed for access to the sources and control of the markets for commodities of high demand among the Lowland elites: obsidian, jade, quetzal feathers and other products, among them cacao, cotton and spring salt (Figure I4). Obsidian came from El Chayal and Jilotepeque (Río Pixcayá) in the central Highlands, and Ixtepeque in the eastern Highlands; jade came from the Motagua River basin, the only known source to date; quetzal feathers came from the cloud forest areas of Verapaz and the Sierra de las Minas, north of the Motagua River. Spring salt came from Salinas de los Nueve Cerros, northwest of Alta Verapaz, near the Chixoy-Salinas River (Arnauld I986:29, I40, fig. 3; Van Akkeren 2012:38-4I, 75-76). ${ }^{12}$

Figure 14. Sources of high-demand commodities in the Maya area.

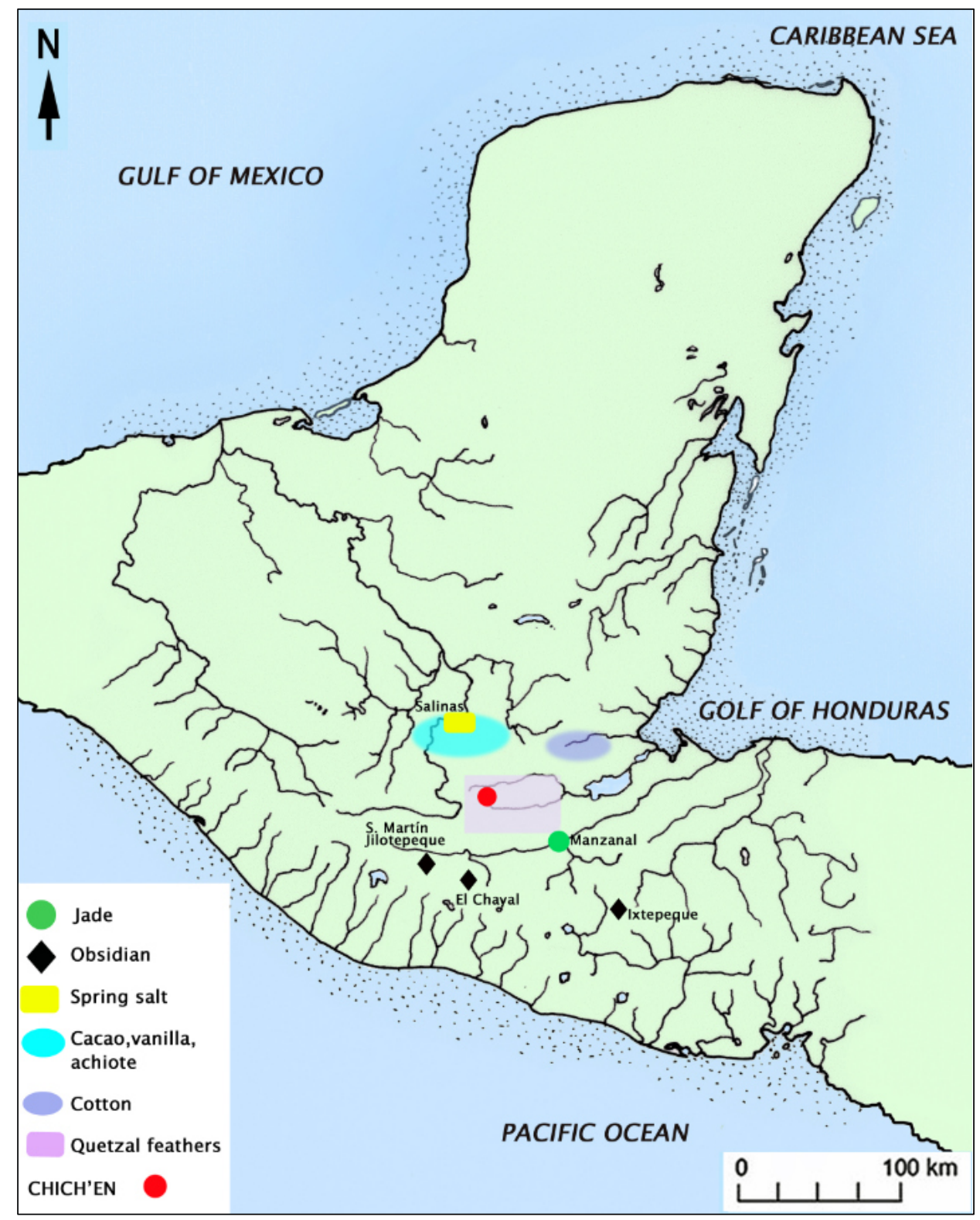


The two major trade routes between the Highlands of Guatemala, Petén and Yucatán, Mexico, were:

(a). The river-land route of Alta Verapaz, or "Alta Verapaz route" along the Chixoy, Pasión and Usumacinta rivers.

b). The river-land-sea route, or "Motagua-Caribe route" along the Motagua River valley to the Caribbean Sea, also connecting Lake Izabal and other routes leading to south Belize and central Petén. ${ }^{13}$

In principle, the two routes allowed equally efficient transport, the route of Alta Verapaz for being shorter, but that of the Motagua-Caribbean allowing, in large part, faster navigation. At first glance, the two routes complemented each other considering that the first linked the Highlands with the Gulf Coast, while the second gave access to the Caribbean coast (Figure 15). The two corresponding commercial systems were competitive, especially in the northeastern region of Petén, where centers like Tikal had access to both routes (Arnauld I990:350-35I).

Figure 15. Principal trade routes of the Classic Maya world.

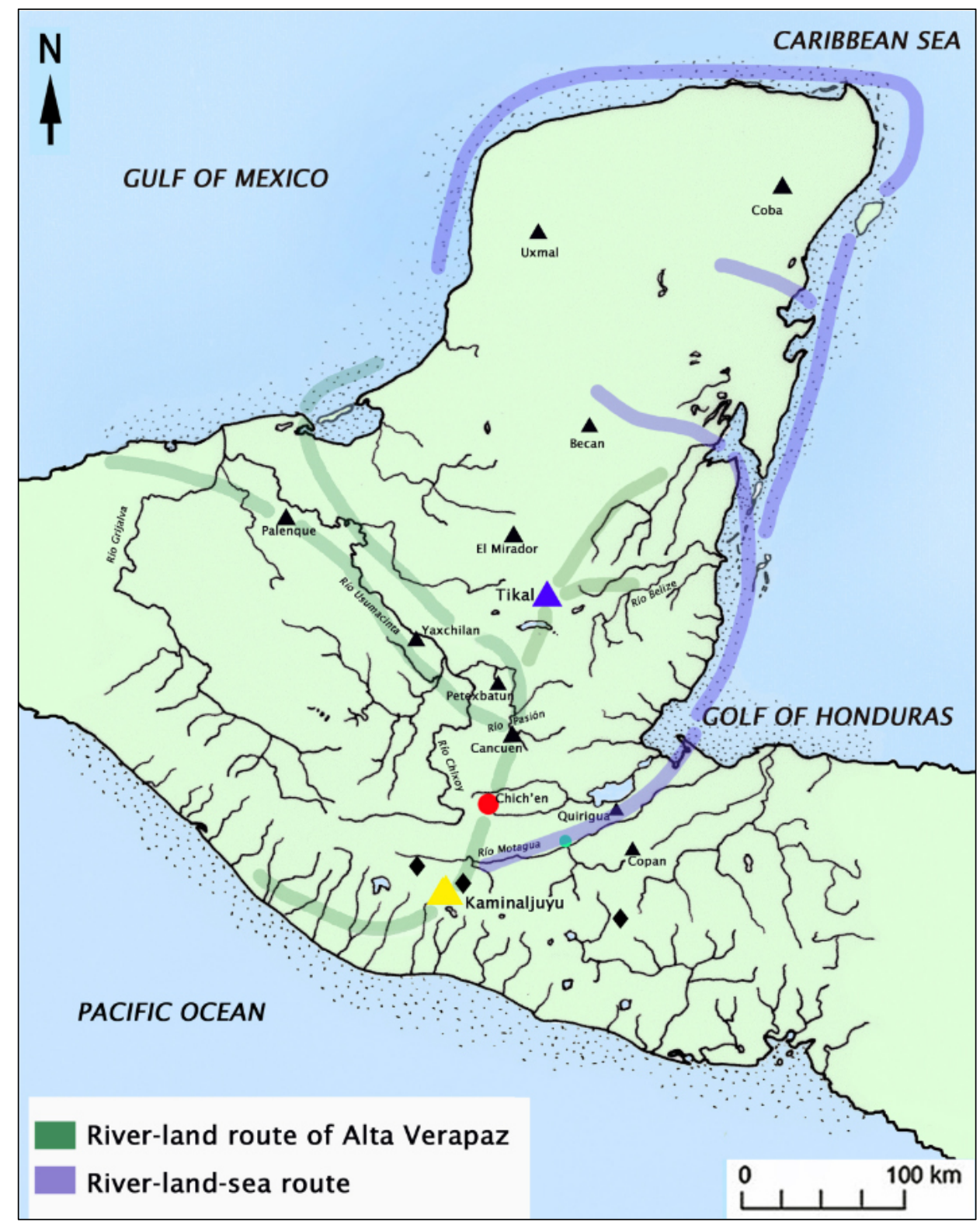


The Alta Verapaz route. The Cobán plateau was a significant station on the Classic period route between the highland sources of obsidian, jade and quetzal feathers and their lowland destinations. There were several primary and secondary sites that were occupied from the Preclassic period until the Spanish invasion. This attests to both its strategic significance and its long-term importance along the trade corridor between the Highlands and the Lowlands (Arnauld I986:Ir6-ı20, I990:347-367).

The main land route for transporting the aforementioned products, coming from the Pacific coast and the central Highlands, where the obsidian sources are located, followed the Salamá valley north to reach the valley of Tactic (see figure 6). From here on, there were two routes to reach the Cobán plateau. The first followed the course of the Cahabón River, bordering the Xucaneb Massif to the northwest. The second was shorter, though more arduous. It crossed the Xucaneb massif over the La Cumbre pass, between Xucaneb Mountain and Chichen Mountain before arriving at the major site of Chich'en on the other side (Figure I6). From Chich'en, the footpath continued north across the plateau to Cobán before descending the piedmont of Alta Verapaz into the Lowlands. Goods were then transported by water down the Chixoy-Usumacinta and Pasión river systems to the Gulf of Mexico. The Cobán plateau and the adjoining piedmont are at the interface of the Highlands and Lowlands. During the early colonial period, the lower piedmont area was an important region for the inhabitants of the plateau to obtain achiote (Bixa orellana), cacao, cotton, salt, and chili. In 1676 , the indigenous population of the plateau was under Spanish control, but the piedmont and Lowlands were not (Van Akkeren 20I2:38-43, 6o; BassieSweet 2013:I-8).

Figure 16. The Valley of Tactic. View from the hill shrine Cristo Chi-Ixim. In the background, the Xucaneb massif, and the La Cumbre pass. 2017.

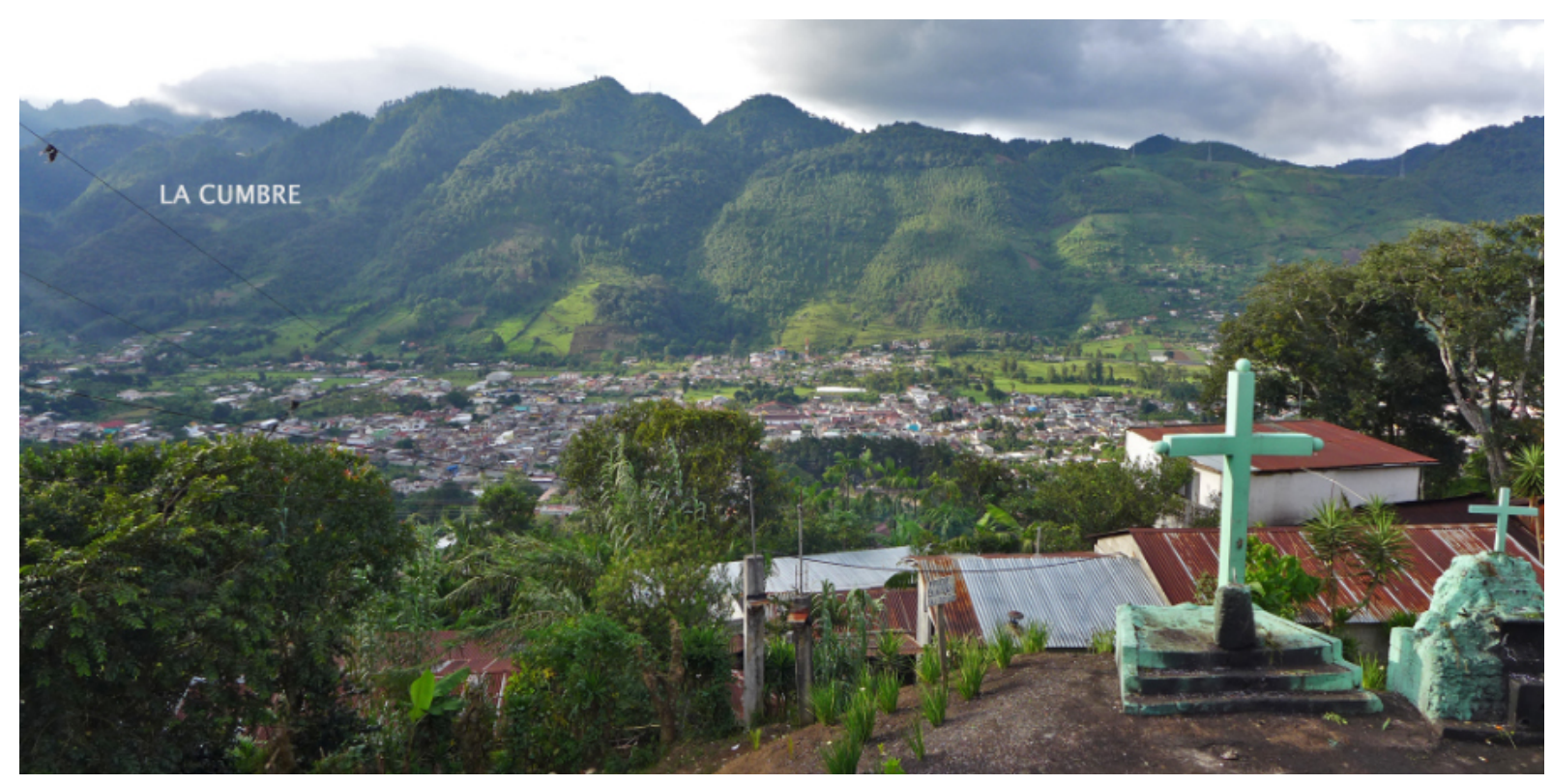


The Dominican priest Francisco Gallego noted that there was a town adjacent to the banks of the Chixoy that was the departure point for downstream canoe travel. Each year, Lacandón, Itzá and other Maya groups from the central Petén came by canoe up the Chixoy to trade their achiote at a fair conducted at this town. The achiote fair indicates that lowland agricultural products were one type of commodity that highland people desired. Regrettably, Gallego did not indicate what the lowland Maya received in exchange for their achiote but given that they still desired obsidian and quetzal feathers those items would likely have been part of the transaction (Van Akkeren 20I2:48, 75-76; Bassie-Sweet 2013:I-8).

It is possible that Chich'en's long occupation was due to its strategic location on the Alta Verapaz route. The valley where the site is settled facilitated the transport and control of the passage of commodities and luxury goods. Being a "rector-type" center, Chich'en could exercise some control over the small centers in the surroundings and thereby monopolize regional exchanges. ${ }^{14}$

Trade also involved cultural and economic exchange. In the sites of northern Verapaz, the cultural and artistic influence of the Petén centers is evident. This suggests direct contact with Tikal, who controlled the trade route between Petén and Kaminaljuyú in the south.

\section{PILGRIMAGE ROUTES}

Long distance merchants faced challenges and dangers during their travels. It should, therefore, not be surprising that they stopped at the altars of caves and mountains along the way, depositing offerings and begging for the protection of the deities. ${ }^{15}$ In fact, the pilgrimage routes ran parallel to the trade routes.

The Maya have a long tradition of making offerings to the mountain deity whenever they passed by his mountain or crossed over his pass. During the colonial period, the Dominican friars were dismayed to learn that their native carriers continued to perform such ceremonies even after their conversion to Catholicism (Feldman 2000:172-73). In the nineteenth century, Sapper (I895) noted that the Q'eqchi' burned copal incense and placed a stone, flowers and pine boughs at mountain passes as offerings. At particularly important mountain summits, they also performed ceremonial dances. In their $197 \mathrm{I}^{-} 73$ investigations of the Salamá valley, Sharer and Sedat noted that these customs were still practiced by indigenous traders transporting Salamá pottery by footpath to the market at Cobán. The trail used passes over three major ridges between Salamá and Cobán. In each case, every merchant in a trading party carried a stone from the base to the ridge top in addition to his heavy burden during the climb to the summit, as a demonstration of their humility and their respect for the mountain. The large accumulations of stone on each ridge top testify to the antiquity of both this custom and this traditional commerce (Sharer and Sedat 1987:450). It is expected that the landscape along the major land route, from the highland sources to the lowland markets, would feature in the core 
mythology of the Maya. The Xucaneb Mountain is visible from great distances and acts like a beacon marking the Cobán plateau as the gateway between the Highlands and Lowlands. The identification of deities with landscape features, specifically with mountains, is well documented in Mesoamerica. The long history of veneration of the Xucaneb mountain deity, and his role in contemporary stories supports the interpretation that the Classic period antecedent for Tzuultaq'a Xucaneb was God L-Gathered Blood. While God L has been associated with tobacco and cacao, the iconography of his owl regalia strongly indicates his primary role as the patron god for long distance obsidian merchants, who faced the dangerous challenge of traveling through foreign and often sparsely inhabited territory, where attack and robbery were likely common occurrences. The terrain and weather also presented enormous obstacles to overcome. It is not surprising that such individuals would seek powerful supernatural help and that the landscape of their travels would be incorporated into these beliefs. It is inconceivable that Classic period traders would not have left offerings to Xucaneb Mountain when they crossed the La Cumbre pass (Bassie Sweet 2019:194-198).

Travelers who used this route probably also visited the Mestelá cave before arriving at Chich'en.

The archaeological site of San Pablo Xucaneb I, located on one of the main paths from Tactic to Carchá, lies on a terrace at the base of the eastern slope of the Xucaneb valley, at an altitude of $1720 \mathrm{~m}, 500 \mathrm{~m}$ east from the 'chapel' (Christian church). It had an extension of approximately 0.56 ha. The site dates from the Late Classic or Early Postclassic period. It had a closed-type ballcourt, characteristic of a "Postclassic transition" (Arnauld I986:263-264; I58, fig. I8).

Figure 17. Church of San Pablo Xucaneb and outdoor altar. 2017.

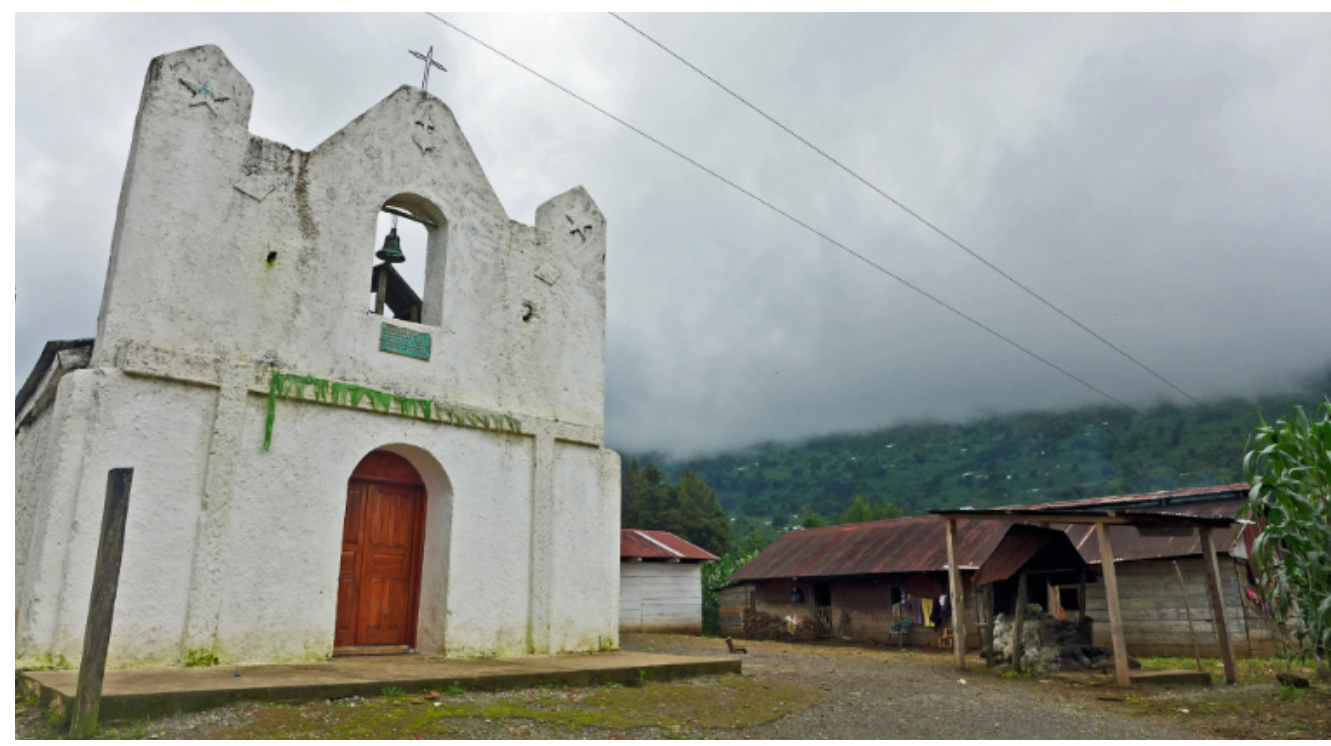


Near Chich'en, the small village San Pablo Xucaneb, located in the same place, faces the Mestelá river, the Xucaneb Mountain, and the entrance of its cave (Figure ${ }_{17}$ ). There is an outdoor altar on the left side of the church, where contemporary pilgrims deposit offerings and perform their petition ceremonies, mostly related to rain and the cultivation of maize, and to honor Tzuultaq'a Xucaneb (Figure I8). Next to the cross stand two stalagmites from the cave (personal communication of local people, 2017). This confirms the sacred character of speleothems, the structures formed by dripping water inside the cave.

The surveys led by Woodfill et al. (2006:1044-1057), Monterroso (2007:310330) and Demarest et al. (2008:265-279), in caves associated with archaeological sites, demonstrated the intense use of such caves for ritual purposes. The caves of Candelaria, north of Cobán, for example, had an influx from pilgrims from the Terminal Preclassic through the Late Classic. Large quantities of ceramics were recovered in these caves. They are iconographically associated with central Petén. These offerings could be part of the economic activity of many sites, possibly by receiving goods from merchants traveling through their property, or in exchange for the use of and access to nearby caves. Among the gifts or payments received are the ceramic vessels that have been found both in the sites and in the caves. Multiple examples of this pattern of activities have been observed in the Maya area, where the settlement of the centers is directly associated with sacred features of the landscape (Monterroso 2007:319).

Fig 18. Outdoor altar.

Two stalagmites from the Xucaneb cave stand next to the cross. 2017.
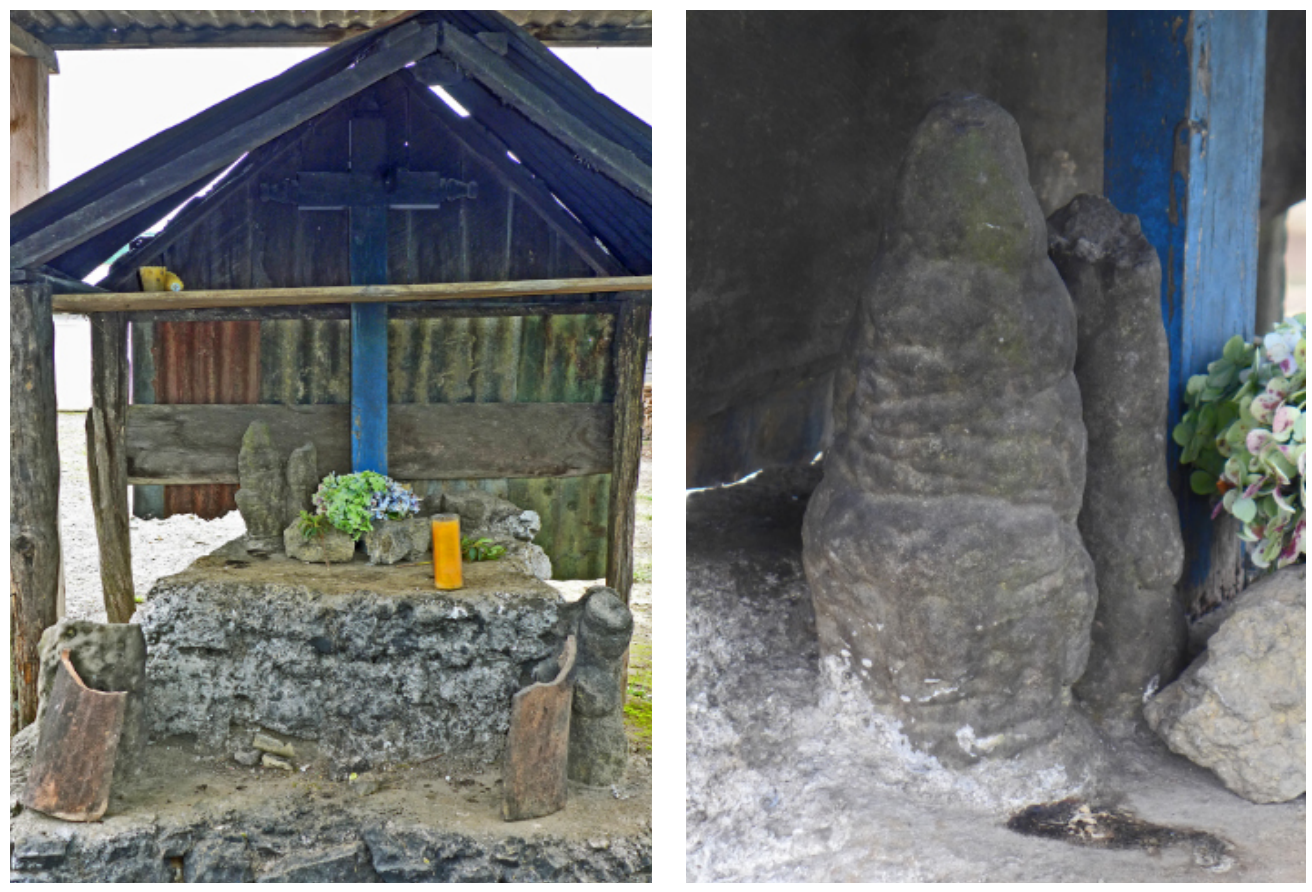


\section{BRIEF DESCRIPTION OF THE SITE}

According to the archaeological surveys of A. L. Smith (1955) and Arnauld (I986), Chich'en covered an area between 6 and 7 hectares. It is an unprotected valley-site lying to the north side of, and $30 \mathrm{~m}$ above the Chich'en (Mestelá) river. The site was built on the slope of a hill, whose natural platforms were transformed into terraces that support the 23 structures, grouped around three plazas, A, B, and C. ${ }^{16}$ Plaza A has a large pyramidal structure, I0.3 $\mathrm{m}$ high (Structure 2), that has been badly damaged by excavations on the top and on the north side (Figure 19). ${ }^{17}$ It had stairways on the east and west sides, possibly on all four sides, and could have been a burial mound (Smith I955:60-62). ${ }^{18}$

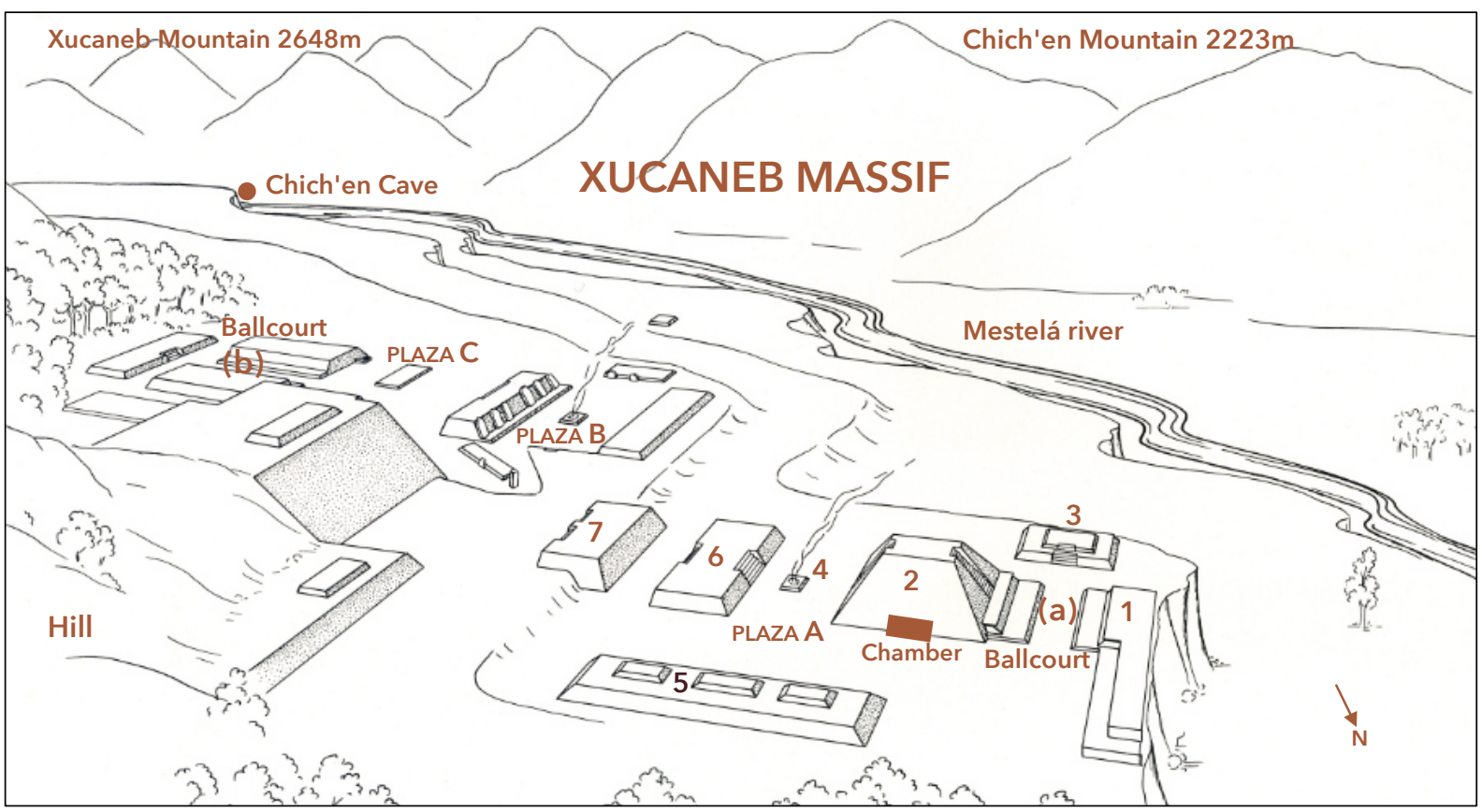

Figure 19. Map of the site Chich'en.

\section{Chich'en has two open-type ballcourts:}

Ballcourt (a), Plaza A, is located at the west end of the site, between structures I and 2, and has a north-south orientation. The west side of the pyramid rises from the east wall of the ballcourt to the top integrating the two structures. This indicates the ceremonial and religious function of the site. Both archaeologists observed, at the center of the playing wall of the west range (Figure 20), a slab with the profile of a [crested] bird carved on it still visible (A. L. Smith I955:fig. 38f; Arnauld 1986:252). ${ }^{19}$

Ballcourt (b), Plaza C, is located at the east end of the site and has an east-west orientation. The site has seven long structures, including Structure 5, probably the residence of the dominant lineage family or a ritual specialist, and several medium-sized structures, two altars and several flat monuments. The quality of the architecture and masonry of stones and slabs is remarkable (A. L. Smith I955:

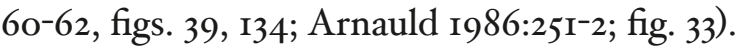


In 2017, we observed two plain stelae and several stone monuments near Structures 2 and 5, possibly moved from their original place. One standing plain stela has a hole drilled from side to side. Other lying stela and stone blocks are covered in moss (Figure 2I).
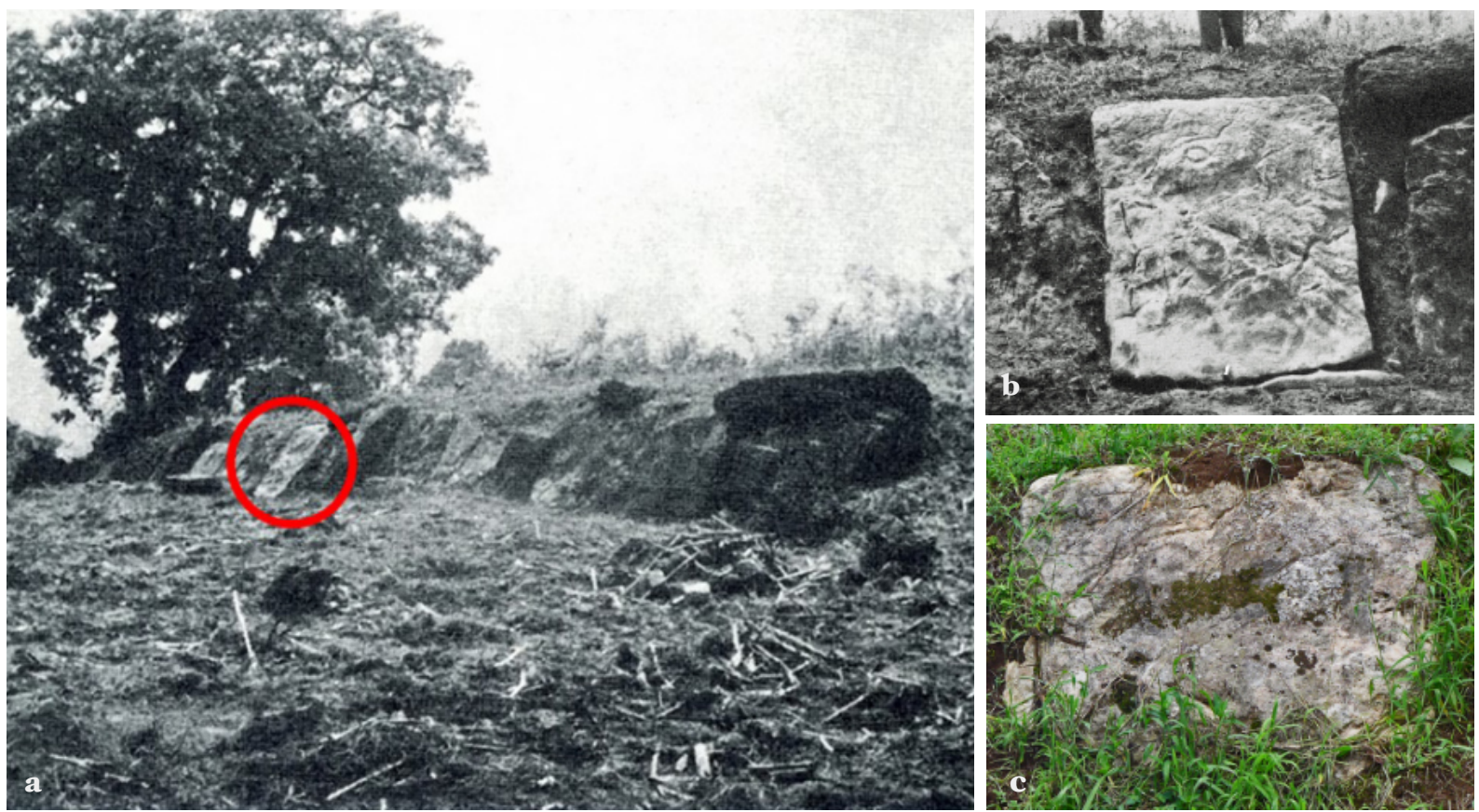

Figure 20. West ballcourt, Chich'en. (a) West range, 1949; (b) Carved slab with a crested bird profile,1949. (c) Carved slab. 2017.

Figure 21. Plain stela (a-c). Chich'en. 2017.
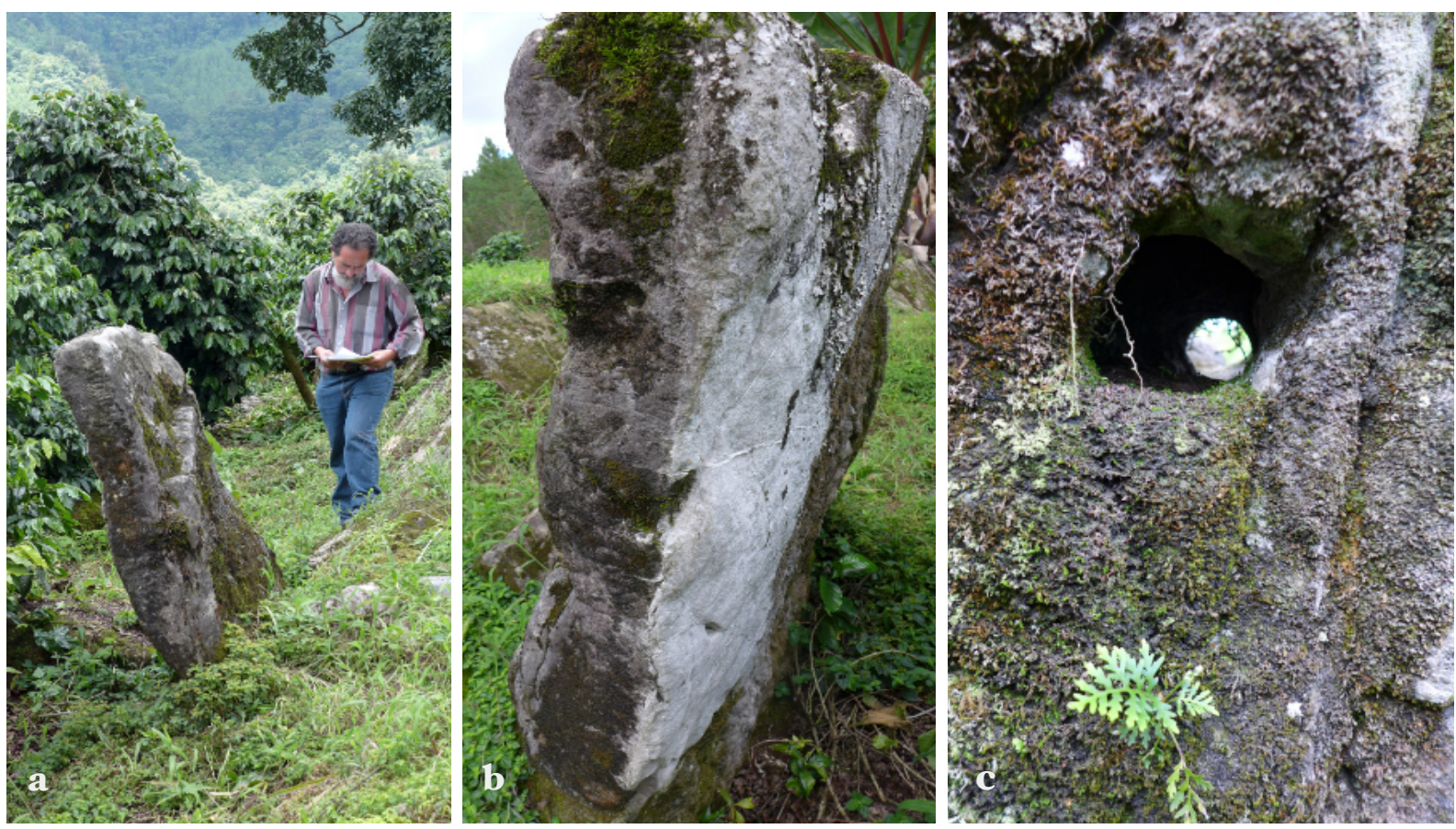

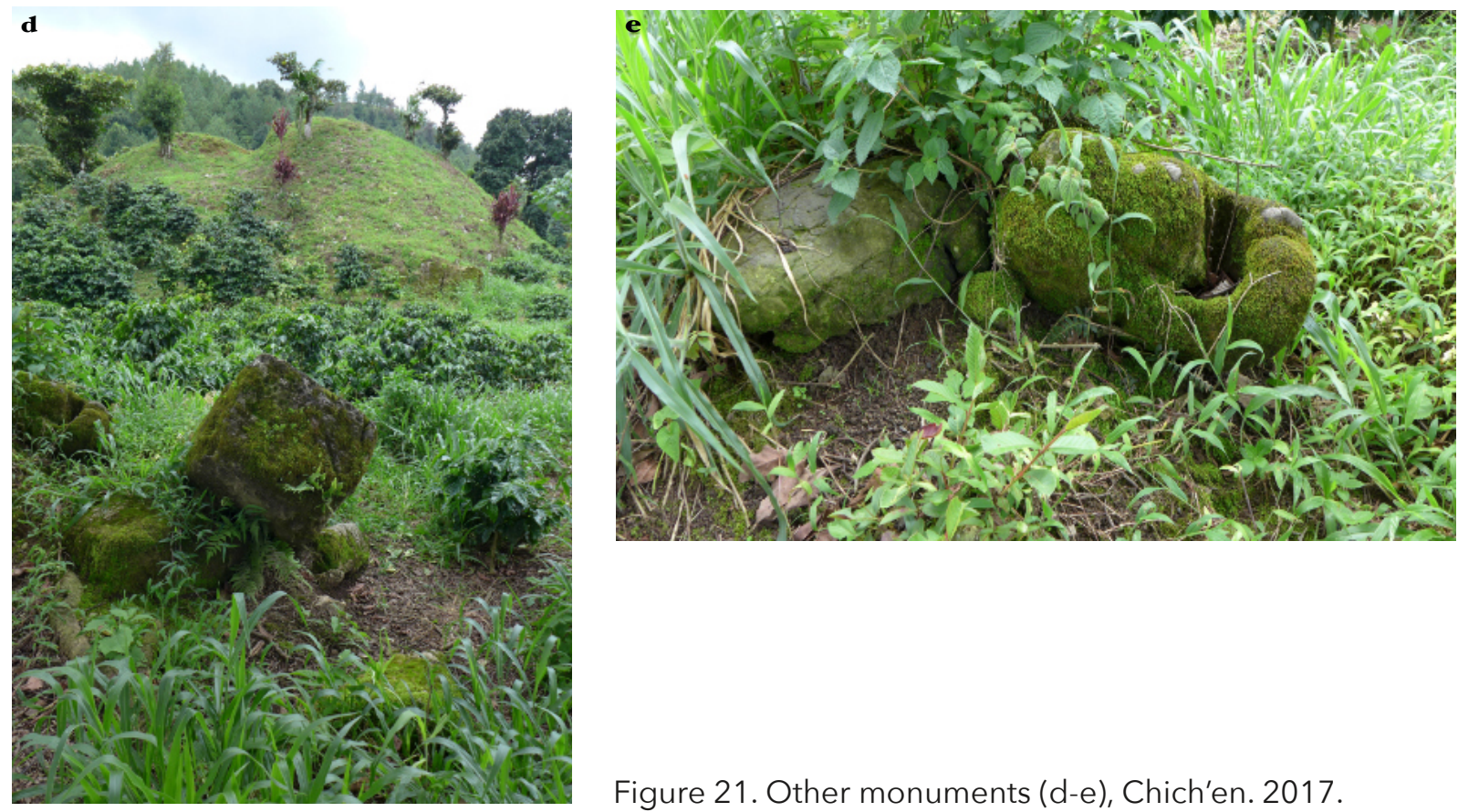

Figure 21. Other monuments (d-e), Chich'en. 2017.

David Stuart (2010:283) notes that stelae were complex symbols, far richer in their ritual cosmological significance than is implied by the simple term Maya scribes used to refer to them: lakam tuunoob, or "large stones." It is important to stress that such monuments were not always used as media for the presentation of royal images and iconographies of power and cosmology. Many examples from the Preclassic and Classic periods were intentionally "plain" tuuns (stones), either natural in form or somehow finished, that embodied multifaceted ideas about time and space, bridging the sky with the substance of the earth. By the Middle Preclassic, the appearance of images on stelae brought new layers of meaning to what was an already complex array of ideas, anchoring episodic representations of history, myth, and the substance of stone itself. ${ }^{20}$

Stone monuments were conceptually related to other more intimate types of precious stone objects, such as crystals used in divination, axes and celts made of jade and greenstone, and mirrors. All these shared an underlying significance that was based on their materiality as substances of the earth and on their visual characteristics as shiny and light-making substances. The careful and timeconsuming work involved in the shaping of large and small stones (not necessarily the sculpting of them) was at the center of craft production from the Early Preclassic onward, when highly skilled craftsmen transformed the rough material of raw stone into divine objects that encompassed important religious ideas, but they were uniquely able to carry their meanings into the public arena as integral parts of artificial and architectural landscapes. As important as large monuments were as media for political and ritual messages, they never lost their basic and essential meaning as stones (Stuart 2010:297). 


\section{CURRENT SITUATION OF THE SITE (2017)}

The long agricultural exploitation of the finca and the construction of a road more than 3 decades ago, for which the hill where the site is located was split in two, have caused irreparable damage, in addition to the loss of a large part of the site. The homes of the finca workers, as well as their corn fields and vegetable gardens, occupy what once were Plazas B and C (Figures 22 and 23).

After the formal archaeological surveys of A. L. Smith (1955) and Arnauld (I986), no other archaeologists explored the site. The site is unprotected and its location, a few meters from the road, increases the risk of predation.

Figure 22. View of the hill and the road to the northeast. 2017.

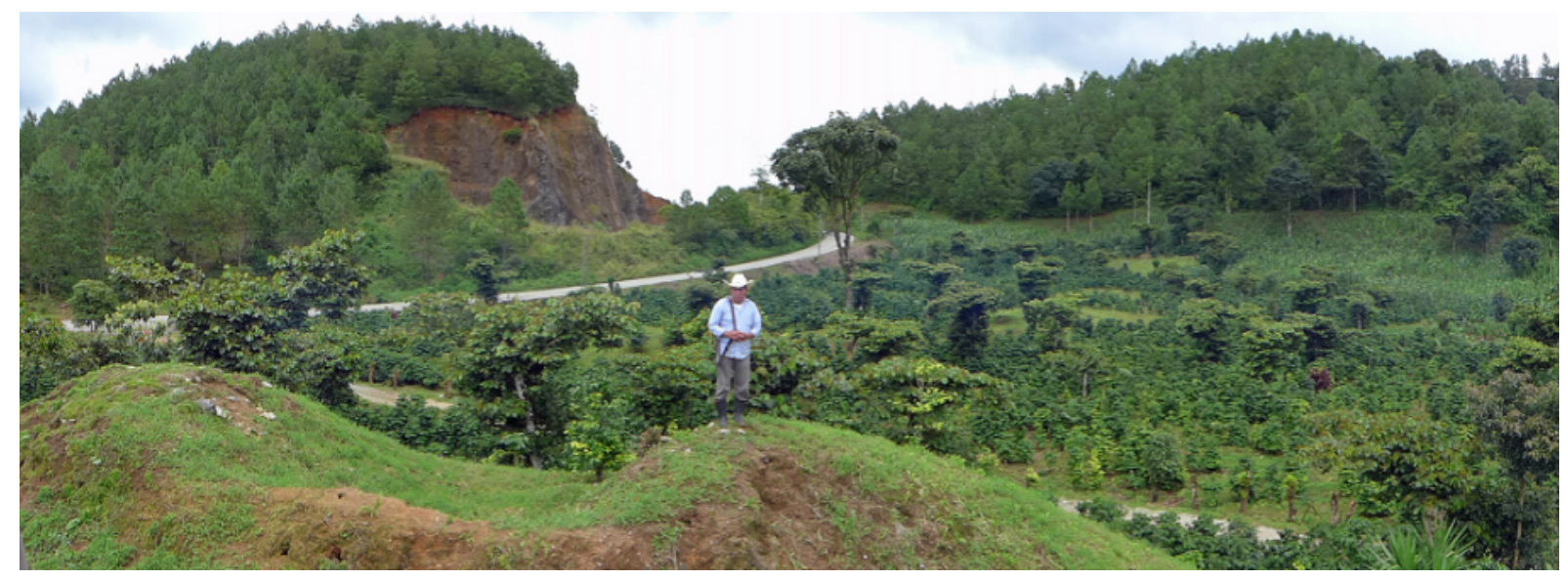

Figure 23. View of the valley to the north from the top of Structure 2. 2017.

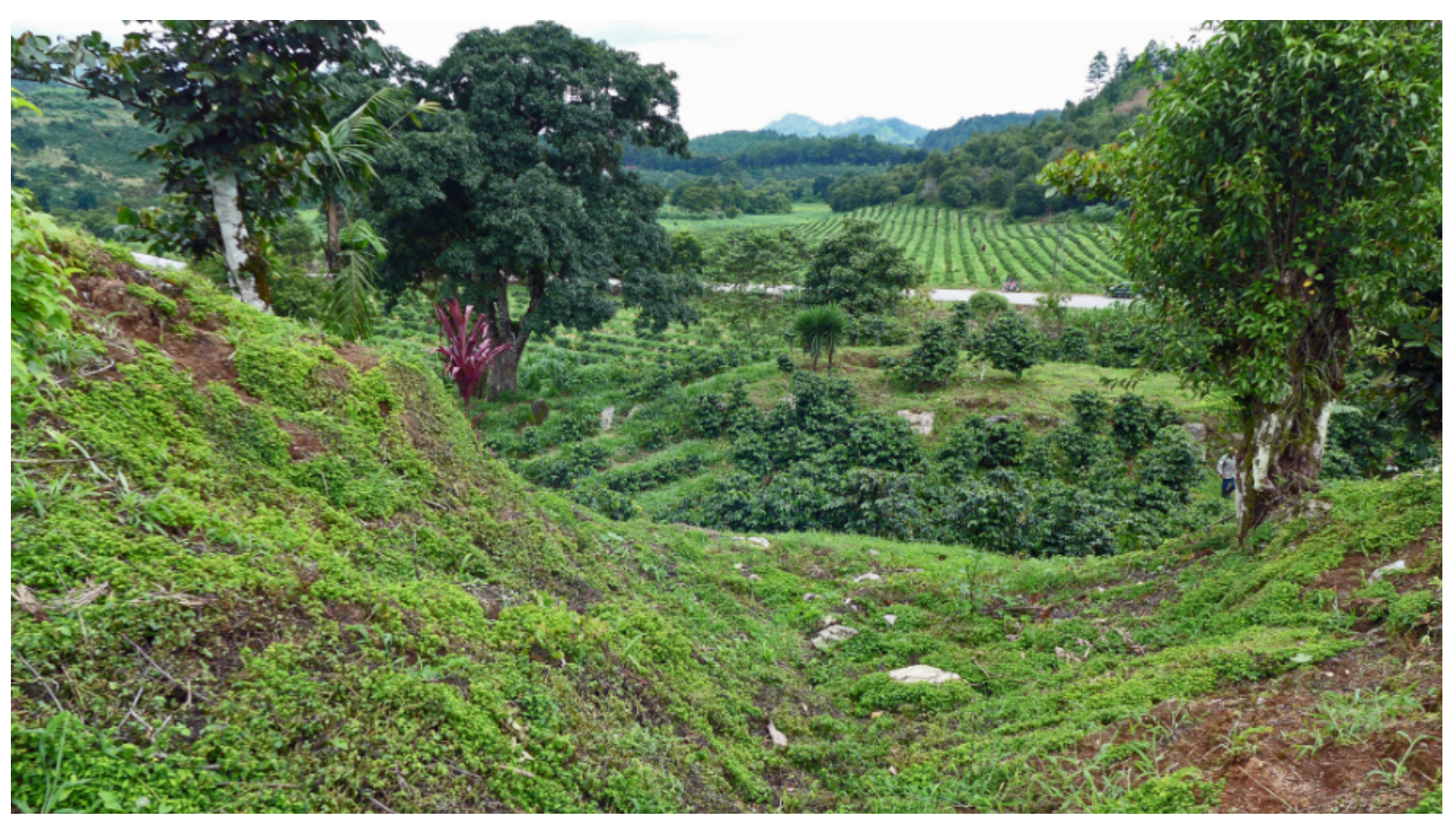




\section{HABITAT AND SOCIETY OF CHICH'EN FROM THE LATE CLASSIC TO THE POSTCLASSIC PERIOD}

According to Arnauld (1986:9), the settlement data indicate that, from the Middle to Late Preclassic period, the Verapaz area was settled by the Q'eqchi' and the Poqomchi'. The regional occupation seems to have developed continuously until the Postclassic period.

The Dominican Friars, who began reorganizing the Verapaz province between 1543 and 1544 , found the region divided into several entities of Q'eqchi' and Poqomchi' lineages, each one with a relatively centralized socio-political structure. The Q'eqchi' lived in the northern district, with Chich'en as the major center of their lineage. The conflicting Poqomchi' groups were divided into two entities in a west-east corridor, from the Chixoy river to the Middle Polochic river. In this area, the basic social unit was the small community of farmers connected to a secondary center, each of them relatively autonomous in their relations towards the major centers of Chich'en to the north and Salto to the south (see figure 6).

Chich'en's surrounding area included secondary centers with domestic habitat scattered in small depressions and hills. The society was probably hierarchical and dominated by the elite of Chich'en. However, the relationship between habitat and the surrounding environment tends to indicate that the communities could have been relatively autonomous, without being subject to a centralizing power emanating from Chich'en (Arnauld I986:II4).

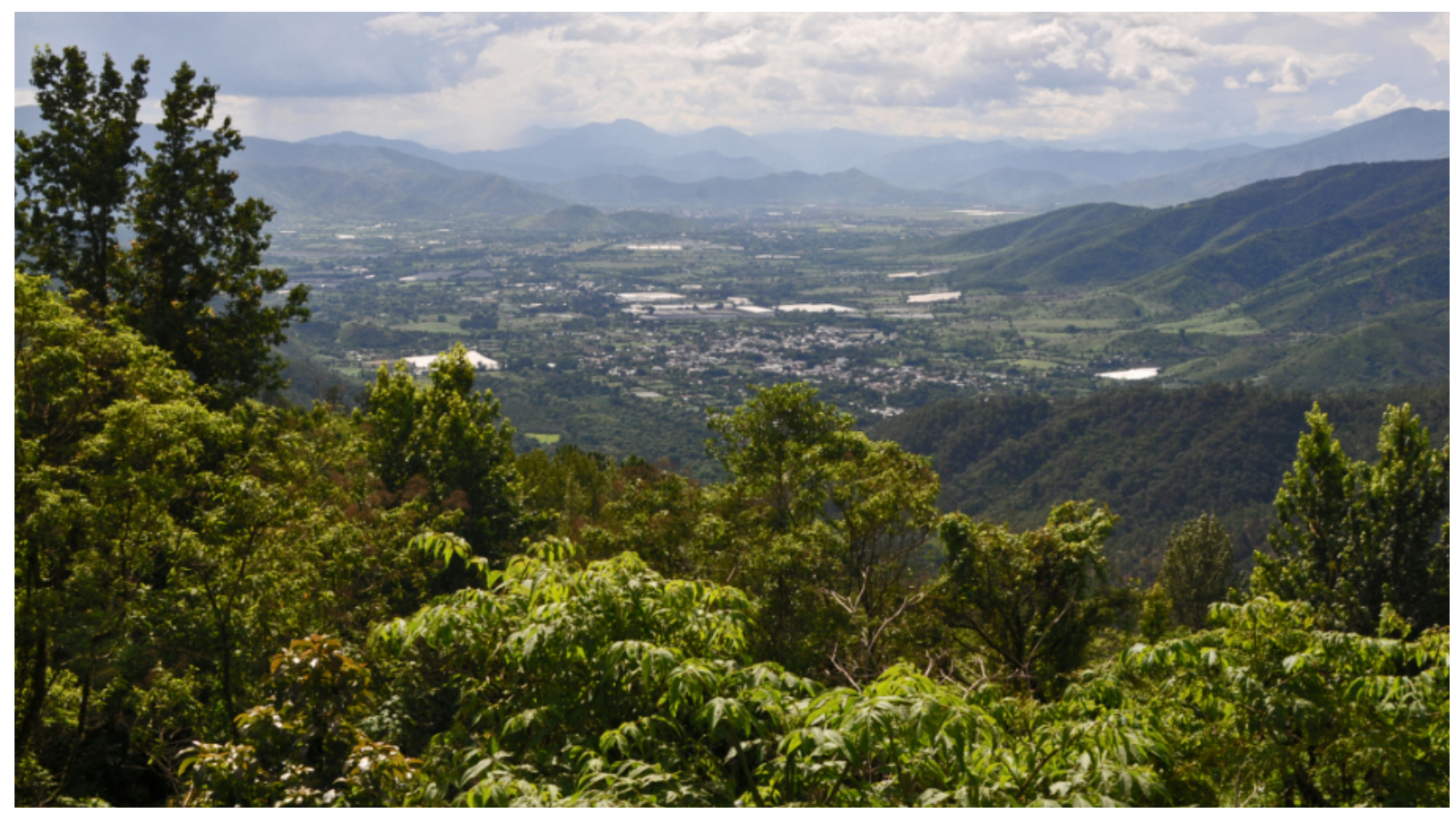


It is not clear if agricultural practices in the northern sector were superior to those of the communities governed by the secondary centers. Chich'en is located in a small depression, whose production was not in proportion to the size of the establishment. It is unlikely that Chich'en was the privileged place of a determining economic power. Its elaborate architecture, as well as its location in the proximity of a cave, suggest that the religious factor was preeminent in its foundation and development. The site would have been mainly a religious center promoting interactions between the communities. In contrast, the site at Salto, located in the extreme south, grouped large dense populations in a complex settlement, pointing to a more centralized socio-political structure. This fact, as well as the ecological setting of Salto, suggest that some degree of specialization in craft production of semi-hard stone artifacts took place, and that the center was involved in regional exchanges (Arnauld I986:II4).

As for the relationships between western Alta Verapaz and the Lowlands, numerous artifacts recovered in the surveyed area come from the northern district and from Petén. This fact clearly suggests that the local elites engaged in exchanges of luxury goods and cultural information with the Petén centers. It is hypothesized that these limited exchanges were instrumental in the formation of a south-north chain of relays for the export of valuable materials (quetzal feathers, serpentine, jade, etc.) from the Motagua valley to the Lowlands via Salto, Chich'en and Chamá (Arnauld 1986:ro).

San Juan Chamelco. 2017.

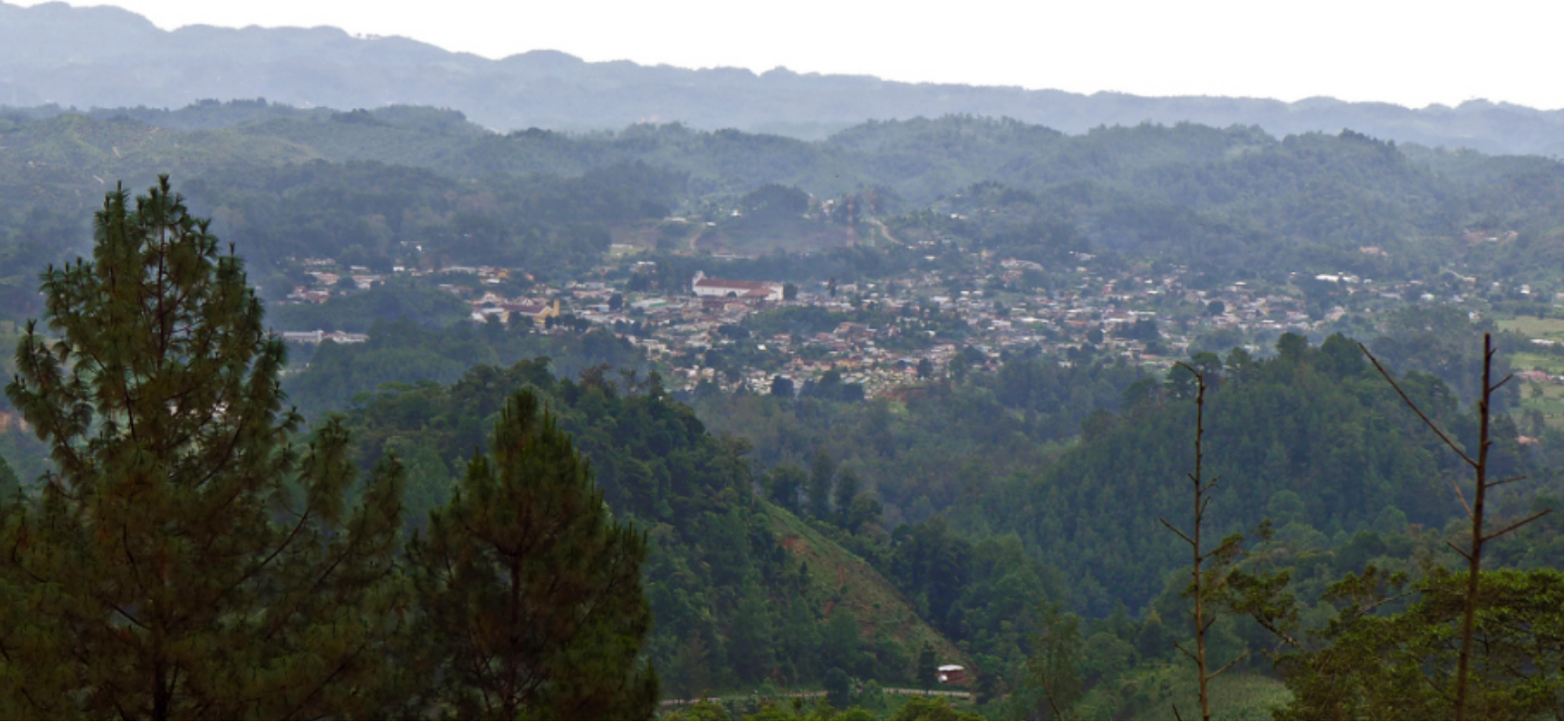




\section{EARLY COLONIAL PERIOD}

A

the end of the Postclassic period, around I50o, the indigenous populations of what is now Guatemala, lived in calpules or large agglomerations ruled by

caciques, who in turn depended on a great Lord chosen by all the principals (Estrada Monroy 1979:15-20).

Colonial documents suggest that Chich'en was still an important agglomeration at the time of the Spanish invasion and the arrival of the Dominicans in the area. There are indications that the social structure, based on a lineage system that formed political and territorial units, was still valid. In the tenamit (the largest type of settlement), each lineage occupied a district and its leaders lived around central squares. Outside the tenamit, their lands included a demarcated territory with scattered villages (Arnauld I978:53; 1986:38-39).

\section{SPANISH MILITARY CAMPAIGNS}

The word 'conquest' evokes images of war and destruction. For some Mesoamerican communities, though, conquest was also synonymous with opportunity; the opportunity to become conquistadors themselves. During the first half of the I6th century, Mesoamerica would be conquered in the name of the king of Spain. Historical records tell us that it was at the hands of a few bold and daring Spanish captains that this titanic clash between two worlds ended with the subjugation of the entire region. ${ }^{21}$ But another version exists. The Spaniards had powerful allies, in the form of indigenous warriors. Their story, despite having been recorded, was until recently, neither widely known nor understood. In I997, Florine Asselbergs ${ }^{22}$ discovered a pictographic document in Puebla, Mexico, the Lienzo de 2uaubquechollan, a Nahua painting that recounts the history of indigenous conquistadors from Quauhquechollan (Tlaxcala, Mexico), who accompanied the Spaniards and participated in the conquest of Guatemala (UFM 2007:26-32). ${ }^{23}$

The military campaigns in Guatemala under the command of Pedro de Alvarado and his brother Jorge are known from various sources, beginning with the letters of Pedro de Alvarado himself and the chronicles of the missionaries in charge of the Christianization of the natives. There is also the version of the defeated peoples in the various indigenous titles and documents, which describe in detail the battles with Alvarado's troops and their allied Tlaxcalan warriors. There are, however, few accounts of the 'conquest' of Verapaz, that was never militarily dominated by the Spaniards. In fact, the resistance of Verapaz to Spanish control motivated Bartolomé de Las Casas to select this region for his project of peaceful evangelization (Van Akkeren 2002:55). 
In 1528 , the allied forces of Spaniards and Tz'utujil warriors captured the Chief Cacique of the Q'eqchi's, who lived in the Sierra de Chamá, Verapaz, taking him as a prisoner to Santiago de Guatemala and put him and his warriors to work as slaves in the mines. Due to the rigors of the work and the bad treatment, the slaves rebelled and in this confrontation the Cacique died. The slaves escaped, and upon their return to Tezulutlán, they reported the death of their lord. As their ancestors in ancient times had done, the Q'eqchi' lords gathered in a Great Council in I529, to elect the Chief of Caciques who was to rule them for life. The council appointed Ajpo B'atz, a 29-year-old warrior as the Aj folomná, "Cacique de Caciques" of Tezulutlán. He became the most powerful lord in the region (Estrada Monroy 1979:15-20).

By that time, most of the territory of the current Republic of Guatemala was already in the hands of the Spanish. Only the extreme north (the Petén lowlands), and the southern part of the mountainous landscape between the Sierra de Chinajá and the Motagua valley (Tezulutlán) remained to be dominated (Figure 24). ${ }^{24}$ The Spanish failed to conquer these lands, notwithstanding several attempts, due to the fierce resistance of the indigenous people. That is why they called this territory Tierra de Guerra, Land of War (Sapper 1936:7).

A last attempt was made by Jorge de Alvarado, who launched a new 'entrance' in Tezulutlán around 1530. He was provided with men, weapons, and horses, as well as with the support of the great Tlaxcalan (Quauhquechollan) warriors. The aim was the founding of the first Spanish town in Tezulutlán, which

Figure 24. Verapaz in the $16^{\text {th }}$ and $17^{\text {th }}$ centuries.

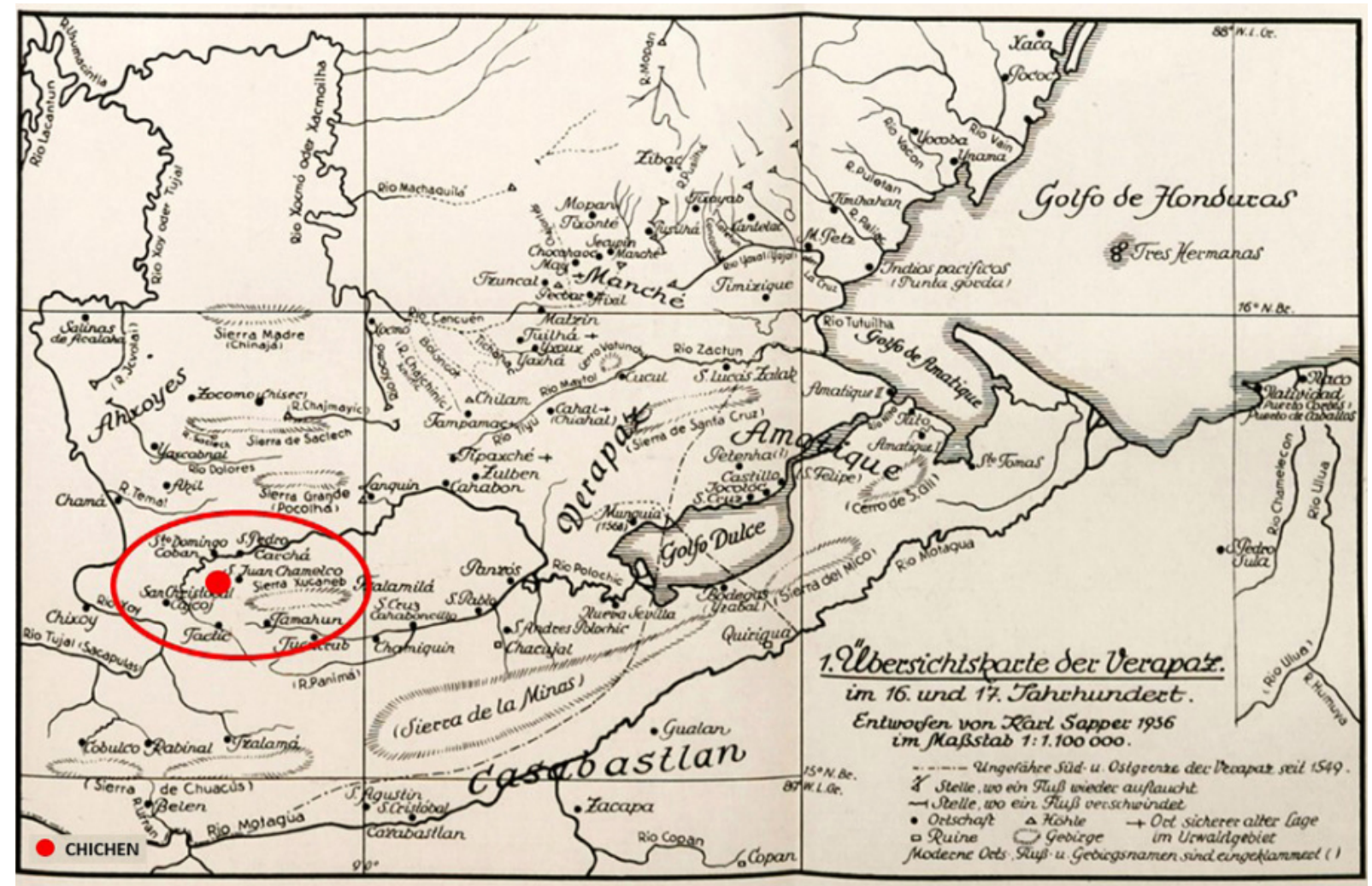


would be named San Jorge. His effort ended in a resounding failure, not only due to the strength and organization of the Q'eqchi', but also due to the support they received from Tz'utujil warriors, who knew the tactics of the Spanish cavalry. From this moment on, all the attempts of the Spaniards to subdue Tezulutlán were futile (Estrada Monroy 1979:20-2I).

There is no information on the outcome of the different military campaigns, but they must have been unfavorable for the Spanish, because no further conquest attempts were made (Sapper 1936:7).

\section{ARRIVAL OF THE DOMINICAN FRIARS IN TEZULUTLÁN}

The Dominican friars Bartolomé de las Casas, Rodrigo de Ladrada, and Pedro de Angulo arrived in Guatemala in $1535 .{ }^{25}$ During the following years they dedicated themselves to learning the K'iche' language. Once the friars had mastered it, they translated the story of biblical creation and the life of Jesus into verses ${ }^{26}$ which they used to predicate the Christian Faith. They also taught the verses to merchants, who had a great knowledge of the lands and the peoples they visited.

Bartolomé de las Casas intended to bring the natives of Tezulutlán under Spanish rule and convert them in a peaceful manner to Christianity. He and his friars began to inquire about the provinces and towns bordering the Tierra de Guerra. Las Casas made a special effort to delimit these lands and found that this extensive area included several mountain ranges, largely from the banks of the Chixoy and Polochic rivers, to the Caribbean Sea, including the mountains of the Sierra de Chamá, Xucaneb, the Sierra de Santa Cruz and the Maya Mountains (Estrada Monroy 1979:53). At that time, Las Casas redacted his De Unico Vocationes Modo, ${ }^{27}$ alleging that there is only one proper Christian way to conquer the indigenous peoples, which is using the word of God and not the sword. This manuscript was ridiculed by the Spanish inhabitants of the capital city of Santiago de Guatemala. They challenged Las Casas to put his speculative theories into practice, this being the real reason why the Tezulutlán project was started, in May 1537. Las Casas and Governor Alonso de Maldonado signed the first contract that granted the Dominicans freedom of action in the Tierra de Guerra (Van Akkeren 2002:70).

According to Fray Antonio de Remesal, ${ }^{28}$ the friars selected four converted Kaqchikel merchants who had learned the Christian verses, and sent them to Sacapulas, where a cacique named Don Juan lived. He was interested in their stories and wanted to meet the friars. By that time, the cacique's brother was going to marry the daughter of cacique Ajpo B'atz. This fortunate event motivated Bartolomé de las Casas and Pedro de Angulo to visit Sacapulas. After the wedding, the friars visited other areas to continue their labor with the collaboration of the cacique of Sacapulas. This led, not without difficulties, to the foundation of the town of Tequicistlán, in the Valley of Rabinal, Verapaz, in 1538. The peaceful governance of this town by the Dominicans seemed to have 
persuaded the indigenous population of Verapaz to accept the presence of the Dominicans. The opportunity to enter the Tierra de Guerra, brought the Dominicans to the place where the town of Cobán would be founded, near the

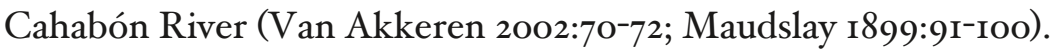

In February 1539, Las Casas received a letter from the emperor Carlos V, legitimating the contract he had agreed with Maldonado in 1537. In 1540, the emperor prohibited the Spaniards (with the exception of the friars and the governor) to enter Tezulutlán, a measure that Felipe II later ratified in a royal cédula dated August 6, 1555 . As a result, Verapaz was, for a long time, relatively free of military interventions, Spanish merchants, and settlers, largely preserving its Q'eqchi' traditions (Sapper 1936:8-9).

The Dominicans were aware of the existence of lineages, kinship ties and of the influence of their leaders. When they began the regrouping or 'reduction' of populations, the assignment of community tasks, and the appointment of authorities, they considered their social, as well as their territorial organization and the hierarchy of the groups (Arnauld I978:54-55).

Between 1542 and 1543 , the missionaries prepared for a large-scale operation. Accompanied by their Tlaxcalan (Quauhquechollan) musicians, they visited different agglomerations and were received, with courtesy, by the Principals. On February 13, I543, the Dominican friars, Angulo, Cáncer and Torres, arrived at the house of the cacique of Sakq'uim. ${ }^{29}$ They stayed in that place, teaching the natives the Christian faith with songs. On May 3, I543, they founded the town of Santa Cruz de Santa Elena (Santa Cruz Verapaz today) and baptized three local caciques. At the beginning of June 1543, the friars proposed to the great Cacique Ajpo B'atz from Chamil, ${ }^{30}$ to found the town of San Juan Chamelco in which he would reside in the center with the other lords in the neighborhoods (barrios) around him (Estrada Monroy I979:I59-I6I).

\section{FOUNDATION OF SAN JUAN CHAMELCO ${ }^{31}$}

On June 24, 1543, people from the different agglomerations were assembled at the location were the town would be founded. Cacique Ajpo B'atz, presided over the ceremony. The liturgical acts began with the public blessing of the surrounding fields, sprinkling holy water towards the four cardinal points. Following the Christian function, the parade of the insignias to pay homage to the chief began. Cacique Ajpo B'atz, accompanied by the friars, proclaimed that the Chamelco lands would come under his direct dominion. The cacique delimited the grounds that would form the central neighborhood of San Juan, those around the church where he would establish his residence, as well as a nearby site to build the chapel of San Juan Bautista. The processional tour then visited the grounds assigned to the other lords and their respective families in the new neighborhoods; for example, the district of San Luis to the northeast, with a chapel dedicated to Holy King Louis of France, ${ }^{32}$ and the districts of Santo Domingo and Santa Catalina with their respective chapels (Estrada Monroy I79:I70). 
Fray Pedro de Angulo called the great Cacique de Caciques Ajpo B'atz to take his place in front of a small carved stone fountain, to receive the sacrament that would make him a Christian. After being baptized with the name of Juan, Ajpo B'atz took his place on the platform of honor and sat on a mat that was covered with a large monkey skin. ${ }^{33}$ Two warriors covered his back with a feathered cape. At the end of the mass the assistants went to pay tribute to "Cacique de Caciques" Don Juan, who from then on, was called Don Juan Ma Tac B'atz. ${ }^{34} \mathrm{He}$ facilitated the evangelization and peaceful occupation of the lands of Tezulutlán (Estrada Monroy I979:I7I-I72; Van Akkeren 20I2:82-84).

On this occasion, the Dance of Hun Ahpú and Xbalanqué was performed. The lively and precise narration of the bonfire scene by Estrada Monroy, merits reading, especially when it comes to the stage setting and the dramatic fire and smoke effects, so ingeniously simulated. The dance commemorated the journey of two heroes to the underworld, where, after having jumped into the bonfire to die, they returned to life and defeated the demons (Estrada Monroy 1979:172-174). There is a remarkable similarity with a passage from the Popol Vuh, which relates how the heroes Hunahpú and Xbalanqué sacrifice themselves by launching into the fire pit in Xib'alb'a to become the sun and the moon. Considering that this dance took place in San Juan Chamelco in ${ }_{1543}$, it is necessary to look for an explanation, since Estrada Monroy does not specify his sources. ${ }^{35}$

The origin of the sun and the moon resulting from the immolation of two gods or heroes in a pyre or oven has been documented in Q'eqchi', K'iche', Tzotzil, Otomí, Totonac, Nahua, Cora, and Huichol communities, extending from Guatemala to West Mexico. ${ }^{36}$ Though in different variants, creation myths were part of the Mesoamerican tradition. They derived from ancient, common sources, which were gradually transmitted and transformed as Mesoamerican peoples interacted with each other through millennia (Chinchilla Mazariegos 20I0; López Austin 1993, 200I; Olivier and Martínez 2015, cited in Chinchilla Mazariegos 2018:35).

Dances were part of a long tradition in Mesoamerica that preserved its original aspects until the early Colonial period. Diego de Landa ( 1566$),{ }^{37}$ observed that, on the day called Kawak the Yucatecans performed the Xib'alb'a Ok'ot, a dance representing a large bonfire and also played the ballgame. Both performances were related to the creation of the world. The Relación de Dzonot (1579), ${ }^{38}$ describes a fire ceremony performed by a priest named Ajk'in, "He of the Sun", who blessed the fire and, like Hun Ajpu, jumps into the fire to become the Sun of the new era.

In the Mixtec codices, images of the performance of the New Fire ceremony correspond to transcendental political moments, such as foundations and investitures. The Aztecs celebrated the New Fire ceremony to mark the start of the 52-year calendar cycle, conceived as the beginning of a new era (Figure 25). These calendrical moments were used for political purposes: accession ceremonies, beginning of a dynasty, political foundations, dedication of buildings, war rituals, or mythological representations (Van Akkeren 2012:I82-I83;190). 
The Dance of Hun Ahpú and Xbalanqué performed during the foundation of San Juan Chamelco with the bonfire scene commemorated the rise of the sun and the moon and a new era. The baptism of Cacique Don Juan Matac B'atz also marked the beginning of a new era for Tezulutlán. It represented the beginning

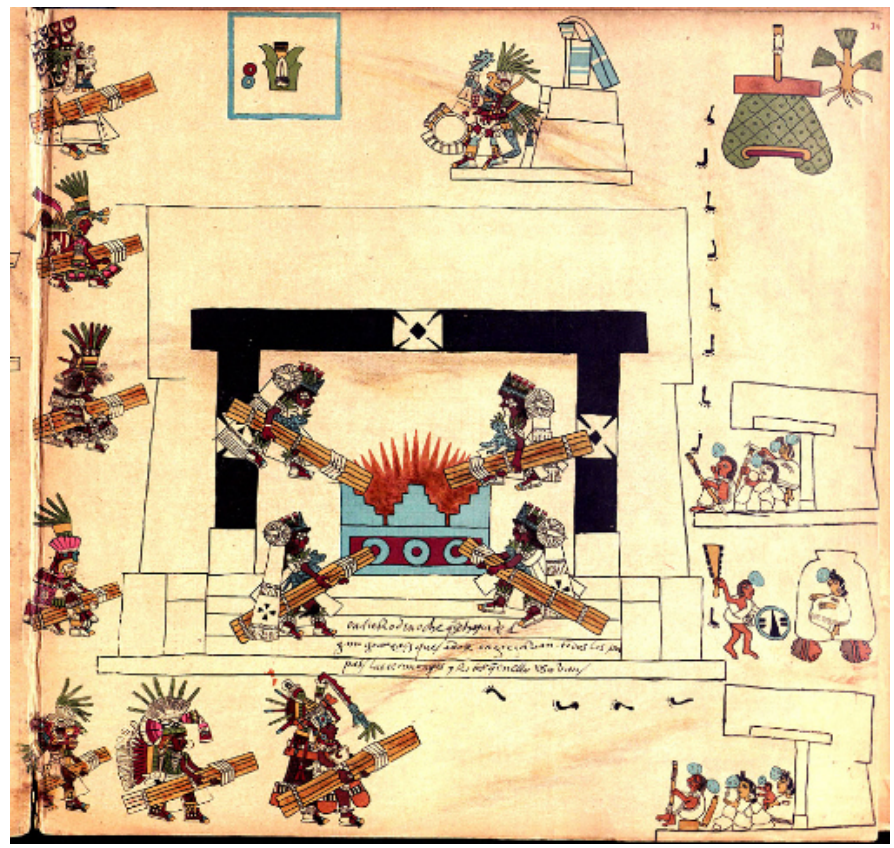

Figure 25. New Fire ceremony performed by the Aztecs at the beginning of a 52-year calendar cycle. Codex Borbonicus, page 34. of the Christian era in the region that had fiercely resisted Spanish rule. The founding of the town on the feast day of San Juan Bautista, who was assigned as the patron saint, was not coincidental. The Dominicans were familiar with the Saint John's Bonfire festival, starting at sunset on June 23, on the eve of the feast day of Saint John the Baptist, on June 24. This popular feast in Europe is itself the result of a syncretic process. The Feast of Saint John closely coincides with the June solstice, also referred to as Midsummer in the Northern Hemisphere.

Fray Luis Cáncer conceived the idea of adapting the Dance of Hun Ahpú and Xbalanqué to communicate to the indigenous people the idea of the resurrection of Christ. This is how, later, in the new dance called Baile de los Diablos or "Dance of the Devils", the heroes, dressed as devils, died in the bonfire and resurrected in the image of Jesus Christ and the Virgin Mary, symbolizing their triumph over the demons of hell. The personages changed, but the dance was preserved leaving the spectacular fire scene intact (Estrada Monroy 1979:173-174). These events led to the start of a syncretic process, triggered by the Dominicans and welcomed by the indigenous peoples, as a survival strategy.

The Spanish mendicant friars intentionally introduced the combination of Old-World dance and drama as a means of supplanting indigenous religious beliefs and practices. The initial relationship between the Aztecs and the Spaniards provided a blueprint for the conquest and conversion of other Indigenous American cultures, often through feast celebrations and theater. Franciscan friars studied the Aztec annual, sacred festival cycle in order to understand its elaboration through public ceremony, dance, and song. Fray Pedro de Gante, the Flemish Franciscan friar, arrived in Mexico in 1523. Many scholars credit him with giving rise to and authoring some of the earliest New World missionary dramas. De Gante recognized his lack of success in attracting natives into the church patios for mass. Once he finally discovered that they considered singing and dancing as forms of prayer, he incorporated them into the Christian liturgy. He recognized the modes of Aztec worship and was willing to meet the natives on their terms in order to get across his message. As a result, he incorporated melody and drama into the Christian display (Madsen 1961:377; Trexler 1984:193-194, cited in Taube, R. 2009:48;54;64-66). 
Such performances needed extensive preparation and were expensive. They must, therefore, have been part of a well-prepared strategy. Hill (200I:I-II) ${ }^{39}$ presents an extensive description of the Fiesta del Volcán held in the main square of the colonial capital Santiago de los Caballeros de Guatemala, in November I680, based on the accounts of the chroniclers Fuentes y Guzmán, who was himself responsible for organizing the event in I682, and Domingo Juarros, who mentioned that the festival had to be suspended due to the expenses incurred by indigenous participants. Hill pointed out that these performances also led to the general process of impoverishment of the Kaqchikel at the end of the colonial period.

\section{FOUNDATION OF SANTO DOMINGO DE COBÁN}

With the help of Don Juan Ma Tac B'atz, the Dominicans founded the town of Santo Domingo de Cobán, on August 4, I543, on the small esplanade of a hill, where a deity called Mon'a was venerated. This location was the pre-Hispanic religious center known as Chi Mon'a. Replacing the idol, they placed a large wooden cross on a masonry base in front of the grounds that the church and the buildings for civil justice would occupy (Figure 26). The local people gave the cross, secretly, the name of "Santa Mon'a." All the crosses that were placed in the courts of chapels and churches of the new towns received the same name. Chi Mon'a in the center, became the district, or barrio, of Santo Domingo de Cobán, that became important the following year when the Dominicans founded the Convent of the Dominican Order (Estrada Monroy 1979:175).

Figure 26. The plaza, Cobán,1898.

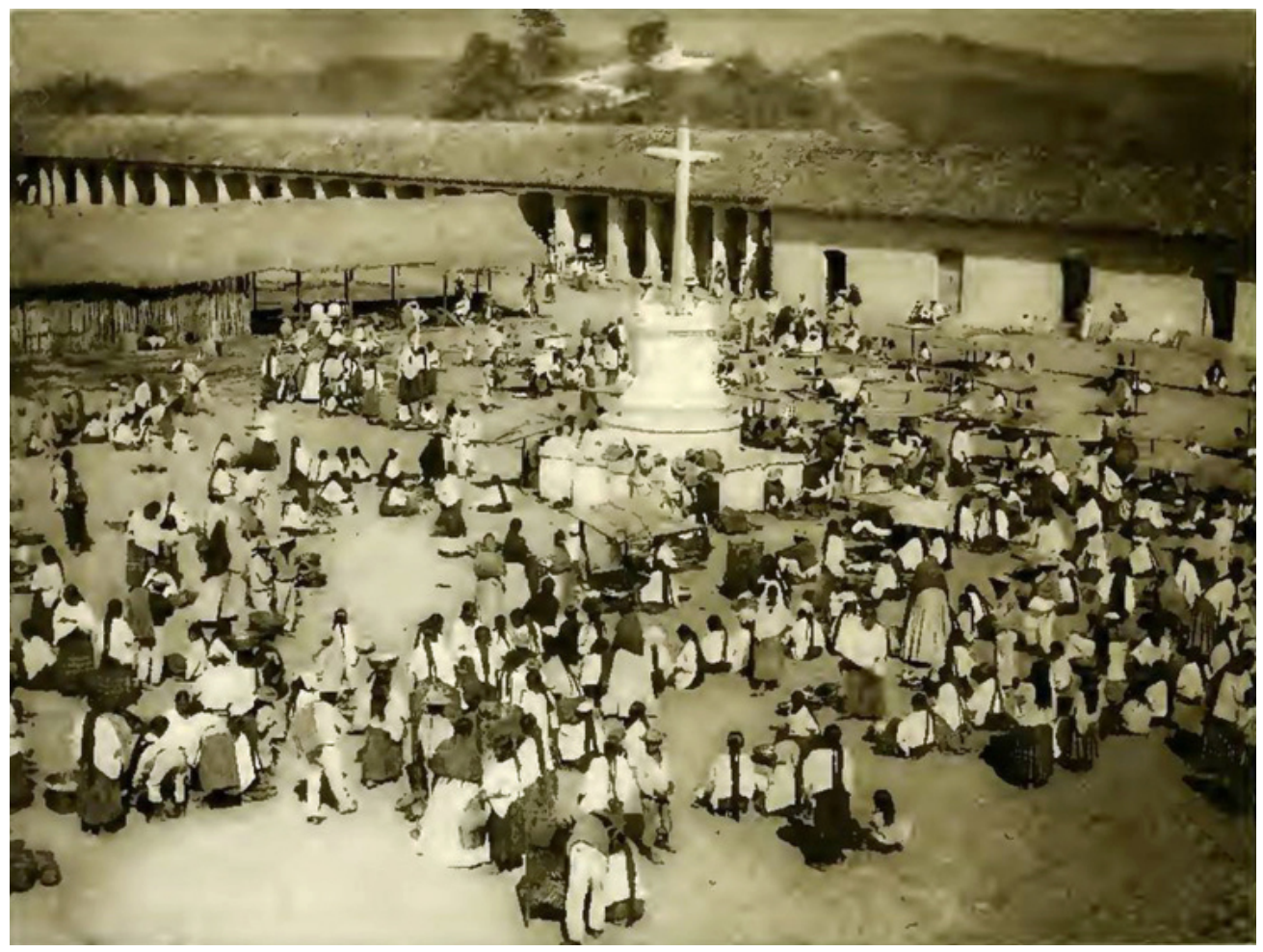


When the Dominicans established the first districts, they kept a detailed record of the origin of the inhabitants. The barrio of Santo Domingo de Cobán was formed with the people of Chi Mon'a and expanded with peoples from the neighboring agglomerations of ancient Cobán: Chich'en, Xucaneb and Al Tun Rax Aj (Estrada Monroy 1979:I75). The original inhabitants of Chi Mon'a must have lived on the banks of the Cahabón River, and in sites such as Chichún or Talpetate. Others, perhaps, dwelled on the banks of the Mestelá River, which was the trade route to Chich'en that continued into the Salamá Valley (Van Akkeren 2012:65-66). ${ }^{40}$

After a few days of having carried out the solemn festivities, the three Dominicans undertook long trips throughout the Q'eqchi' region, founding other towns. It can be concluded from a Q'eqchi' manuscript, known as the Manuscrito de Chamelco, ${ }^{41}$ that in less than two years, the Dominicans founded practically all the towns in Tezulutlán that are known today (Estrada Monroy 1979:I60-167; Van Akkeren 2002:79). The manuscript records the founding dates of 13 towns in Tezulutlán. It was signed by Don Juan Matac B'atz and three other lords of the Cobán districts, on May I, 1546 (Figure 27).

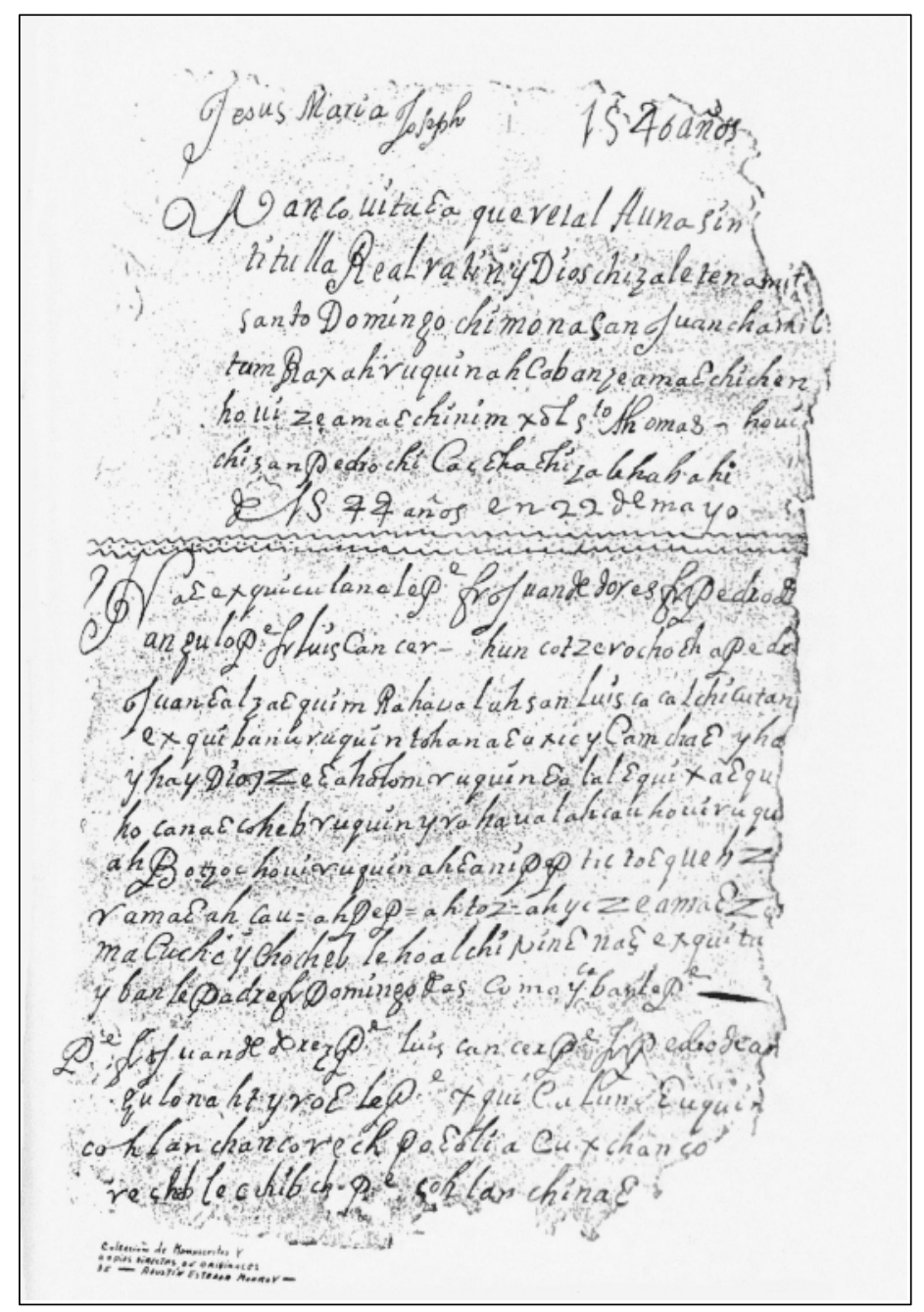

Figure 27. First page of the Manuscrito de Chamelco. 
After the successful campaign of the Dominicans, on January 15, I547, Prince Felipe II issued a royal cédula by which Tezulutlán, formerly called Tierra de Guerra by the Spaniards, would henceforth be called Verapaz, thanks to the work of the Dominicans who brought peace without war, that is, La Verdadera Paz or true peace (Estrada Monroy 1979:250).

The formation of the last neighborhoods of Cobán (Santo Tomás Nim Xol and San Marcos Acalá) could only be concluded after 1555, with the reduction of the Lacandón and Acalá peoples living north of Cobán, who strongly resisted attempts to reduce them. This turbulent period ended with their heavy punishment by the Spanish military forces and Q'eqchi' warriors under the command of Cacique Don Juan Matal B'atz, for having killed the missionaries Fray Domingo de Vico and Fray Andrés López. Don Juan Matal B'atz had just received a royal cédula, dated August 3, 1555, in which he was proclaimed Governor of Verapaz for life (see Arnauld 1978:54-55; Estrada Monroy 1979, and Van Akkeren 2000, 2002, 2012, for an extended review and analysis of these events).

\section{VISIT OF THE Q'EQCHI' LORDS TO THE SPANISH COURT ${ }^{42}$}

Fray Pedro de Angulo started arrangements for a long-awaited trip of the caciques of Verapaz to Spain.

Don Juan Ajpo B'atz, accompanied by three Q'eqchi' lords and their indigenous delegation, arrived at the Spanish Court wearing the best finery of Q'eqchi' lords. ${ }^{43}$ They were received by Prince Felipe, regent of Emperor Carlos V, on February 12, 1545 [?]. Fray Juan de Torres acted as interpreter and introduced the caciques of Tezulutlán and their gifts for the prince, the 2000 quetzal feathers being the most important. ${ }^{44}$ Among other gifts were singing birds, cacao, and wooden boxes containing fabrics woven with cotton thread.

When the prince asked how they obtained the quetzal feathers, they explained that natives who are trained in collecting them, trap the bird when it comes to perch at the nest. With great skill and smoothness, they pull out the long feathers of their tails and release the birds to ensure future harvesting. They also said that quetzals could never be killed or hunted. If a person dared to kill one, he would soon receive punishment, in the form of accidents, dying soon after (Juan López de Velasco, Descripción de la Verapaz, and Raciones de los indígenas k'ekchis, anonymous, in Estrada Monroy I979:I97-198). ${ }^{45}$ 


\section{LAST DAYS OF DON JUAN MATAC (MATAL) B'ATZ}

At the end of his life, Don Juan Matac B'atz lived in the Barrio de San Luis, away from the center of San Juan Chamelco. According to the oral tradition, when Don Juan felt sick, he left his home and confined himself to a cave named Sachamil and died there (Estrada Monroy 1979:336-340). For a long time, this cave was visited by the Q'eqchi', who made offerings to honor Don Juan. The cave collapsed after the 1976 earthquake, and according to informants, only a promontory of stones remains (Rodríguez Girón 2009:II9-120).

\section{CONTINUITY AND IDENTITY}

The social structures, as well as the practice of worshipping ancestors and earth deities, remained quite intact until the $18^{\text {th }}$ century (Arnauld $1978: 53$ ). Many aspects of the Classic Maya cosmovision have survived and have been extensively documented in numerous studies within various disciplines. Maya concepts and symbols survive in the myths, oral traditions, and textiles. ${ }^{46}$ Religious practices in caves and mountains persist until today. The site Chich'en is still considered sacred among the locals (Marta Macz - Huet, personal communication, 2018).

Kistler (2013:12-15), describes what Don Juan Ajpo B'atz means to the people of San Juan Chamelco today. This historic personage not only defines Q'eqchi' indigenous identity but is also considered as the ancestor from whom many Q'eqchi' families trace their offspring. Catholic, Evangelical, and Mayanista communities alike recognize Ajpo B'atz as the founder of Chamelco and refer to him as the grandfather of all. This sense of common descent unites families on the most basic level. Sharing his story at home or during family celebrations further creates the solidarity of Q'eqchi' people. They use historical memory and the politics of Maya resurgence to reinforce the established categories of Q'eqchi' life, and to define their indigenousness in the twenty-first century.

Figure 28. Polychrome three-legged plate.

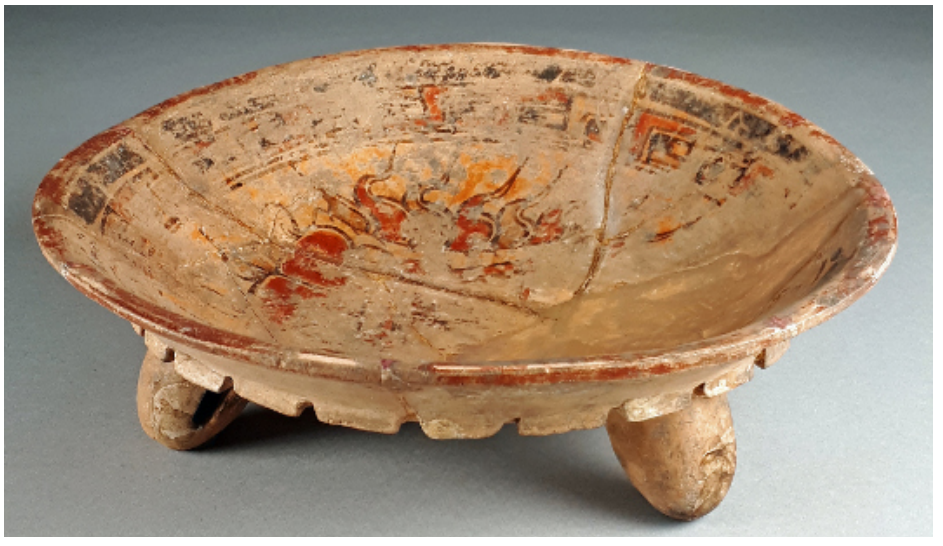




\section{EXCAVATION}

\section{OF GEORGES LÉGER IN 1894}

$\mathrm{B}$ ased on the field notes of G. Léger published by Maertens de Noordhout (1930) and on the site maps by A. L. Smith (1955), we were able to locate the archaeological site, as well as to identify the structures from which the objects were extracted. The field notes are transcribed below:

"About two hours on horseback in the southern direction of the town of Coban, in the department of Alta Vera-Paz, there is a cattle hacienda, owned by the Sierra family for many years. The Indian name for this hacienda is Chi-Chen, which should not be confused with Chichen-Itza. In the middle of a very wide valley, situated more than 4,0oo feet above sea level, surrounded by high conifers, and covered with wild grasses.

There are four mounds of different heights $[$ Plaza A]. Three of them $[$ Str. 2, 6, and 7$]$ have a conical form, one with a small base, the other two with elongated bases; the fourth has a very different shape, it has a length of about 25 meters and a maximum beight of 3 meters [Str. 5$]$.

The 3 conical-shaped mounds have a height that varies between 6 and 9 meters. Curiously enough, the largest of the three conical mounds [Str. 2] appears to be constructed on a base made of blocks of calcareous rock, carved with right angles; only two of these mounds, which I will call tumuli, have been explored, and this, still partially.

The tumulus where the pieces were found, which at first sight, seems to be the most interesting, is the smallest of the conical mounds; it was excavated first, because on one of its sides [north side] I had seen a doorway rather similar to the entrance of a cellar [chamber], with jambs and a threshold of calcareous rock, carved with a right angle.

Apparently, the age of these tumuli must go back to a very distant period, as the Indians living in the neighborhood had not the slightest idea of what these mounds could be, or what they could contain.

Moreover, during the digging, while demolishing the tumulus, I bad to carefully extract the trunk of a fruit tree called "sapote", whose roots penetrated its interior. This type of tree, which grows slowly, has an extremely hard wood, and consequently, it rots also very slowly. This trunk had a diameter of I meter, and it had rotted ...

The excavation of the cellar [chamber] resulted in the discovery of a terracotta plate, broken into several pieces, which fortunately could be reconstituted (Figure 28), some debris, small heads, and feet of terracotta plates (Figure 29). ${ }^{47}$ I then 
decided to excavate the mound at the summit, by digging first a longitudinal trench from the top to the base, and then, crossing it at the middle by a transversal trench, also digging from the top to the base. At a depth of one meter from the summit, I was lucky to discover a true sarcophagus, whose bottom, sides and lid were formed by flat stones of irregular sides, resembling none of the stones known at Chi-Chen, or in its wide surroundings. It is a kind of schist stone, breaking easily into layers. The bottom of the sarcophagus consisted of four stones of unequal size and irregular sides, placed on the soil; the two sides and the two ends were embedded in the soil; the lid was composed of flat stones, like those at the bottom, resting on the sides of the sarcophagus. ${ }^{48}$

It is beneath the lid of the sarcophagus, that two polychrome lidded pots with decorated heads and hieroglyphic characters were found (Figure 30). One of the two pots contained a grayish matter resembling soil; when I removed the content, I discovered a phalanx of human finger and two thin, sharp blades of black obsidian. Inside the sarcophagus, there were some bones and a skull, which, in contact with the air, fell into dust; it was in the sarcophagus that the necklace made of jade stones was found (Figure 3I). It was this discovery that was the most interesting.

The other vases, statuettes, large and small masks, and flint knives were found, scattered in this conical tumulus [Str. 2] and in that described as elongated [Str. 5]. In general, the pots contained obsidian, some of them, a finger phalanx, and all of them contained the same gray matter resembling soil, perhaps decomposed food. Indeed, all the pots were discovered placed straight in the earth of the tumuli and closed by their lid. It is to be noted that the photographed pots were placed in saucers that are not part of the findings.

The excavations had to be conducted with extreme caution. When the first potteries were discovered, I noticed that the extreme moisture in which they were kept had made them so fragile, that at the slightest touch, the drawings or the colors disappeared. Every time a piece was found, it was necessary to cut it with a knife from the earth of the tumulus, as a block. Once exposed to the air and the sun, after a few hours, the earth dried and fell off; the vase resumed its primitive firmness and could be handled without risk.

Note that the great terracotta mask and the stone idol were found in the tumulus with an elongated base [Str. 5]." (Figure 32 and Figure 33).

Here ends the description given by M. Léger (Maertens de Noordhout, 1930:5-9). Free translation by the author.

See Annex I (pages I24 and I25), for the original French text. 

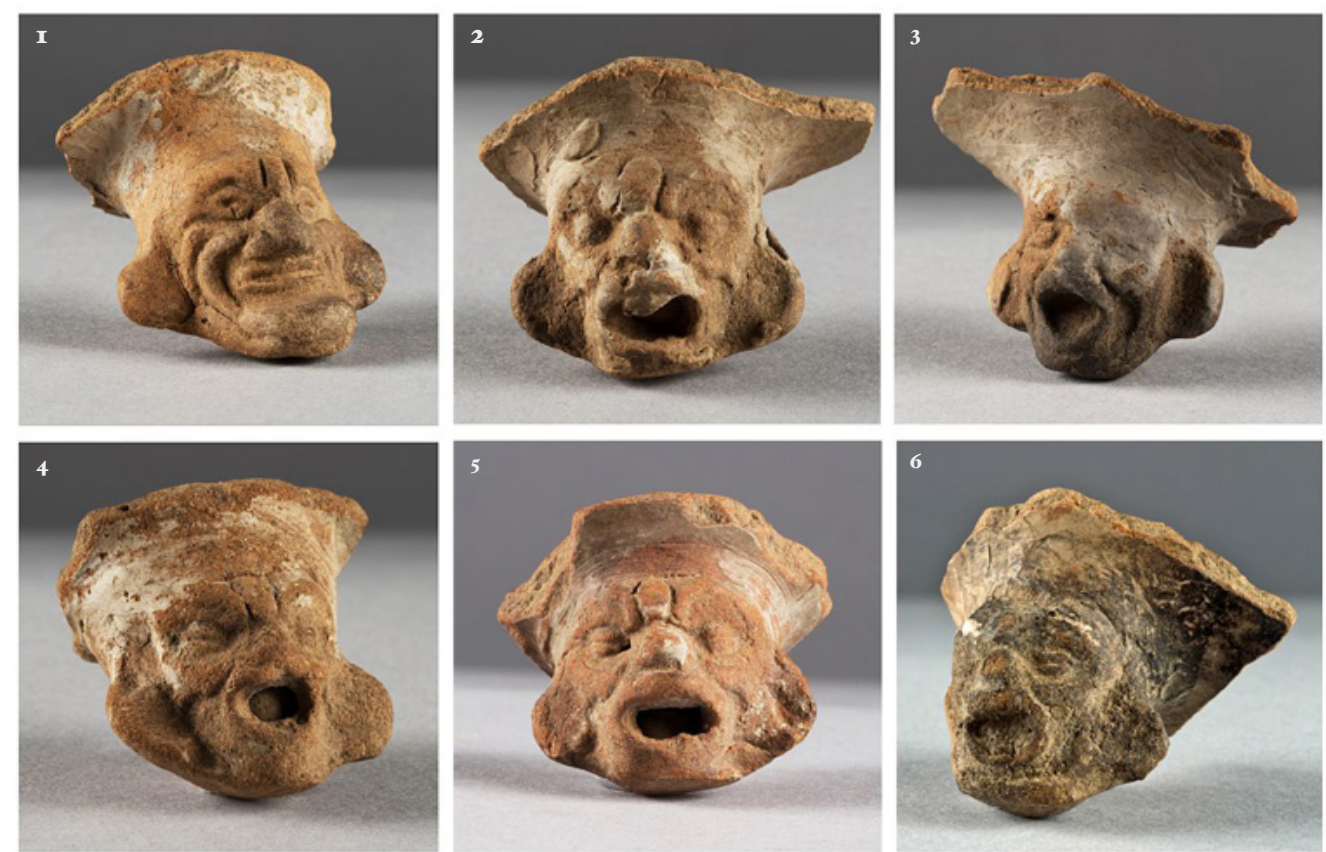

Figure 29. Anthropomorphic heads with clay pellets inside (rattle-type vessel feet).

Figure 30.

Polychrome lidded vessels with zoomorphic heads and hieroglyphic inscriptions.
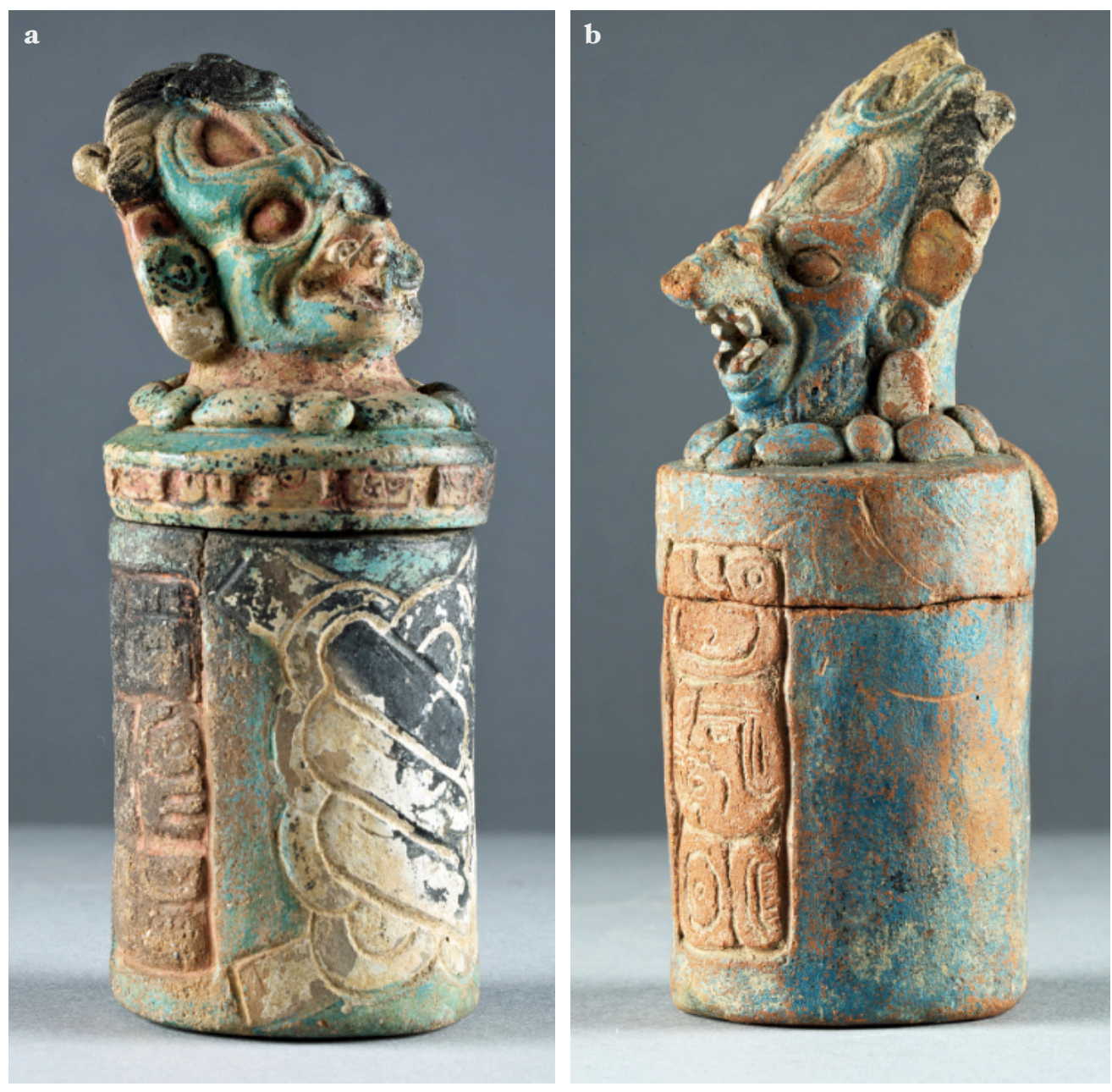


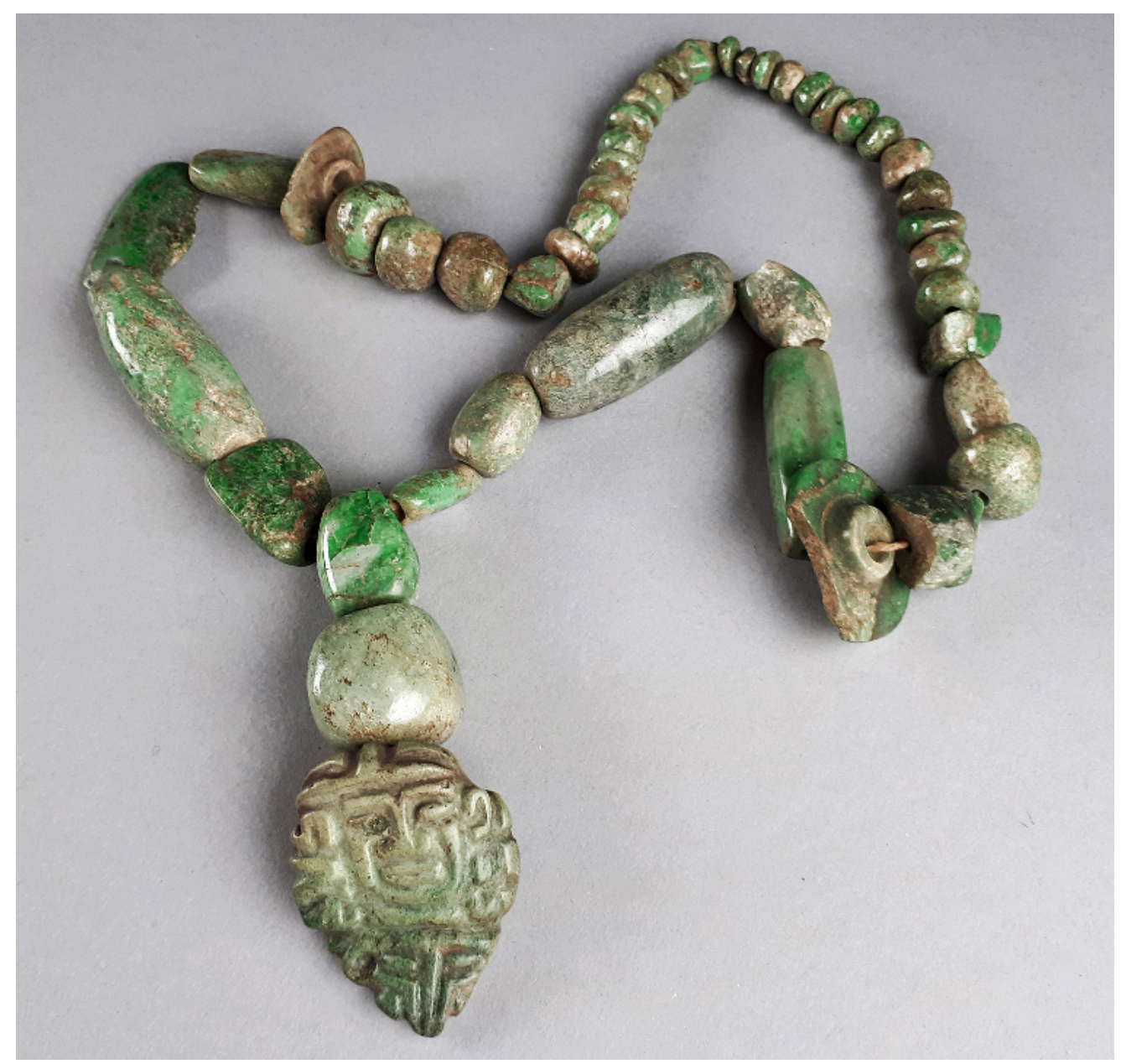

Figure 31. Jadeite necklace with pendant.

Figure 32. Ceramic mask.

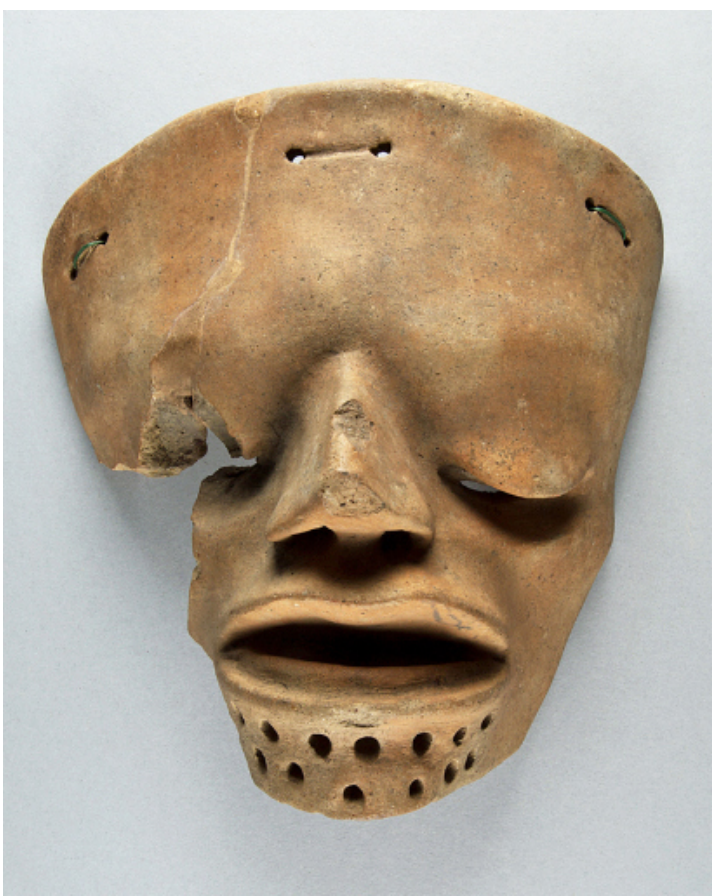

Figure 33. Sculpture (speleothem?).

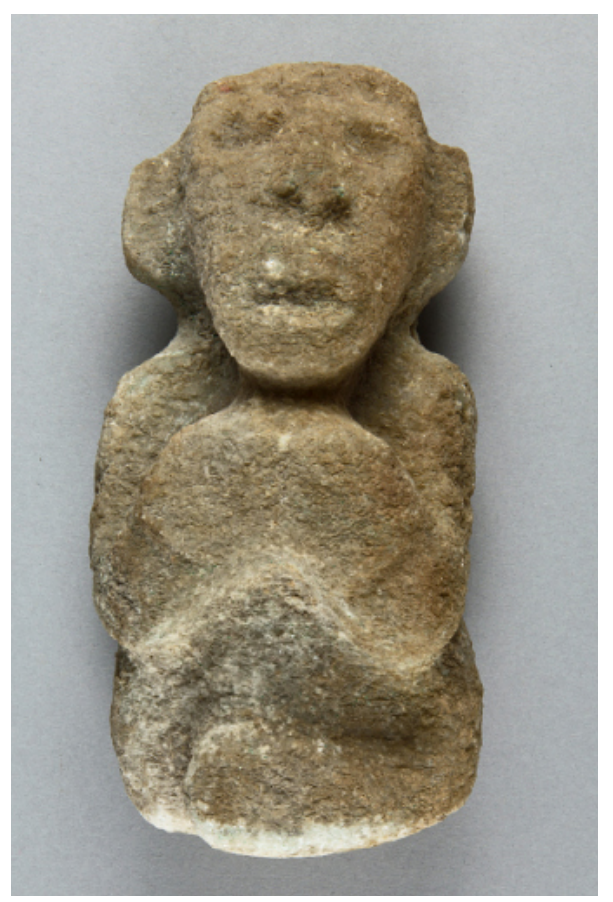




\section{GENERAL DESCRIPTION OF THE CHICH'EN COLLECTION}

$\mathrm{T}$ he study of the artifacts is in its initial phase. I will briefly comment on some pieces which deserve attention but are not included in the iconographic analysis that follows in the next chapter. The predominance of decorated ceramics and the few pieces of household pottery in the collection may be an indication of the religious function of Chich'en. Many pieces seem to have been left as ritual offerings. However, we do not know if Georges Léger selected only the decorated pieces, leaving household pottery fragments and other debris on the site.

\section{POLYCHROME TRIPOD PLATE AND "RATTLE-TYPE" VESSEL FEET}

The three-legged plate (see figure 28) shows stylistic features from central Petén. The image painted on the surface has largely disappeared. It could be the representation of a centipede, as indicated by its segmented body with multiple appendages, but unfortunately, the head is completely erased. The broken plate was recovered from the chamber on the north wall of Structure 2, together with the small anthropomorphic heads (see figure 29) and other non-defined debris.

\section{TERRACOTTA MASK AND STONE SCULPTURE}

The large terracotta mask (Figure 32) and the sculpture (Figure 33) were found in Structure 5. The mask differs from the funerary masks found in the Maya area. Its size $(23.4 \times 23 . \mathrm{I} \mathrm{cm})$ and strange facial features, as well as the holes in the forehead, eyes, nose, and chin, indicate that this piece could be a ceremonial dance mask. Considering its heavy weight, however, it was probably intended to be used as an offering.

The stone idol, which at first glance has a crystalline texture, seems to be made from a speleothem (see figure 18 , page 33). Given the sacred character of caves and their formations, it would not be surprising if this idol is manufactured from a chunk of a speleothem. A laboratory analysis would confirm its nature. According to Brady et al. (1997:732-746), speleothems are thought to have spiritual power or sacredness associated with concepts of rain, fertility, and healing, the most important concerns of agricultural people. Their general use on altars, and as idols, made by pecking of faces on the surface of the stone, have been recorded throughout the Maya area in caches and burials. The specimens recovered from residential contexts are also valuable for analyzing prehistoric social organization. It is known that kinship and residential groups have close ties to particular caves (see pages 25-26). Establishing the source of the speleothems recovered from residences may reveal the composition and boundaries of specific social groups within a given site (Villa Rojas 1946:I6, cited in Brady et al. 1997; see also BassieSweet I99I). 


\section{POLYCHROME LIDDED VESSELS}

In addition to the lidded vases found in the sarcophagus, the collection has five similar pieces that were recovered from the earth around the sarcophagus. The lid of the vessel shown in figure $34 \mathrm{a}$ is missing. The registration card (I96I) describes it as follows:

"It has 3 heads with prominent headdresses and ornaments. One of the heads has a long nose, and an axe on his forehead (Figure 34b). They have a necklace around the neck, and traces of black, blue, white and yellow paint."

Georges Léger did mention that one of the lidded vases found in the sarcophagus, as well as other polychrome lidded vessels (see figure $36 \mathrm{a}-\mathrm{b}$, and figure $37 \mathrm{c}^{-} \mathrm{e}$ ), and plain lidded vessels (see figure $40: 15^{-} \mathrm{I} 7$ ) contained gray matter, phalanges of fingers, and obsidian blades, without specifying which vessels. In Maya archaeology, such vessels are called "finger bowls." The only known example reported in Alta Verapaz is a small anthropomorphic vessel from the site La Cueva, in Santa Cruz, excavated in the r88o's by K. Sapper and E. P. Dieseldorff (Figure 35). In 1896 , E. Seler described it as follows:

"The figure vessel of a kneeling man contained an obsidian knife and the phalanges of the left little finger of a human hand. It is possible, even probable, or merely accidental, that the figure which forms the vessel has only four fingers on the left hand. In the same way, it seems, all the other vessels which were found covered with a bowl or a cover contained obsidian knives and finger joints. Some contained, in addition, pottery fragments, rattle pellets, and pieces (feet) of clay figures" (Seler 1904:105). ${ }^{49}$

Such containers have also been found in Caracol, Belize, in Bonampak, Mexico and in Tikal, Petén (Chase and Chase 1998:308-310; Becker 1993:45-74), suggesting that the practice of obtaining and preserving human bones as a relic was widespread. Relics were preserved and venerated because they held a vital force or soul component. Ancient Maya used to preserve human relics in vessels (caches) or wrapped in sacred bundles.
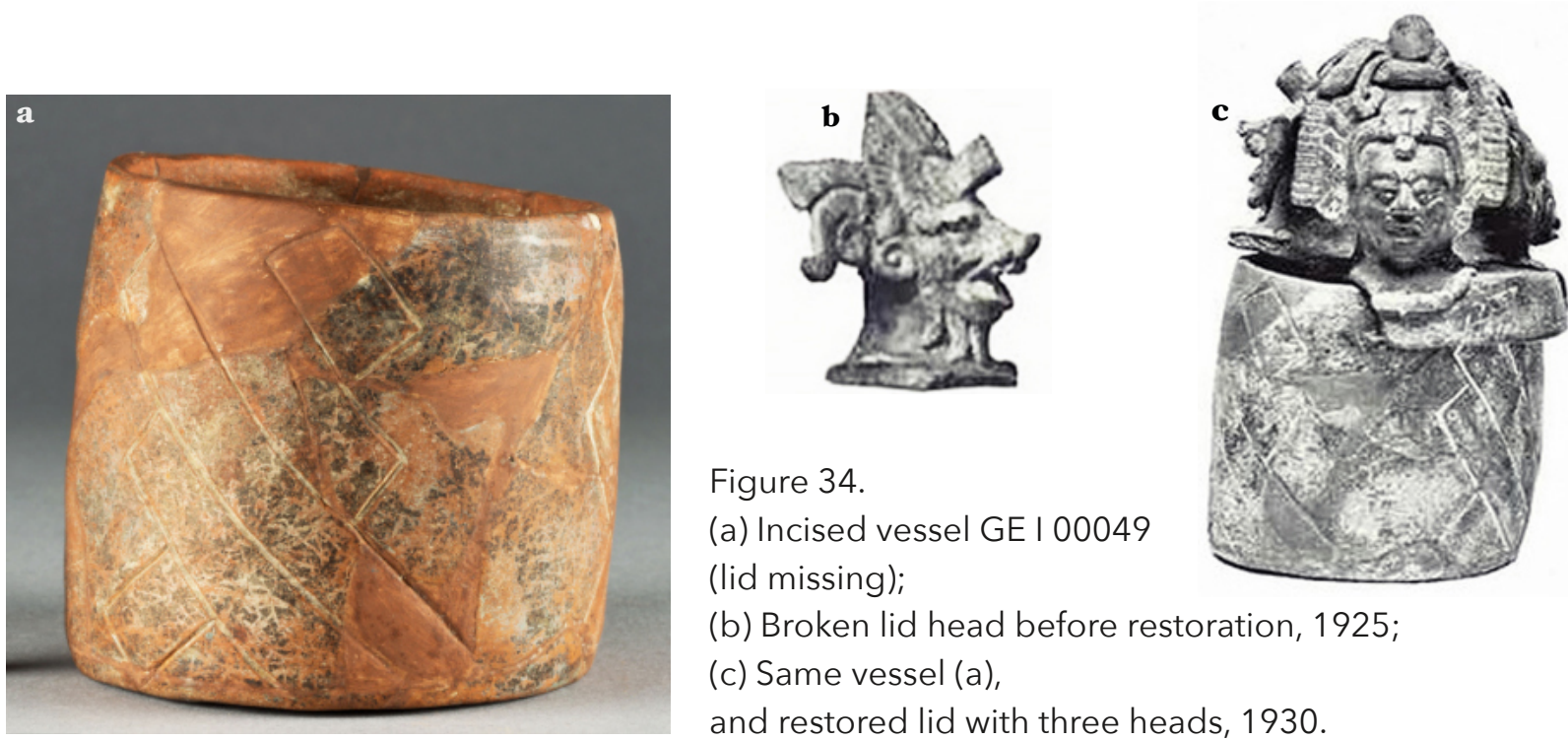

Figure 34.

(a) Incised vessel GE I 00049

(lid missing);

(b) Broken lid head before restoration, 1925;

(c) Same vessel (a),

and restored lid with three heads, 1930 . 

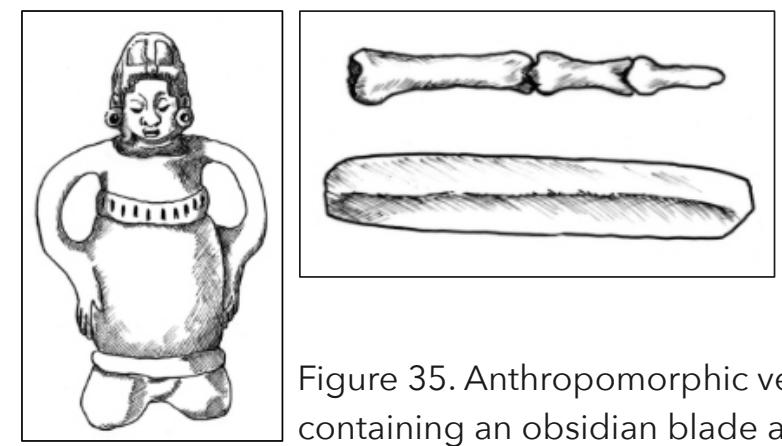

Figure 35. Anthropomorphic vessel with removable head (lid) containing an obsidian blade and human fingerbones.

Figures 36 (a-b) and 37 (c-d-e). Polychrome lidded vessels.
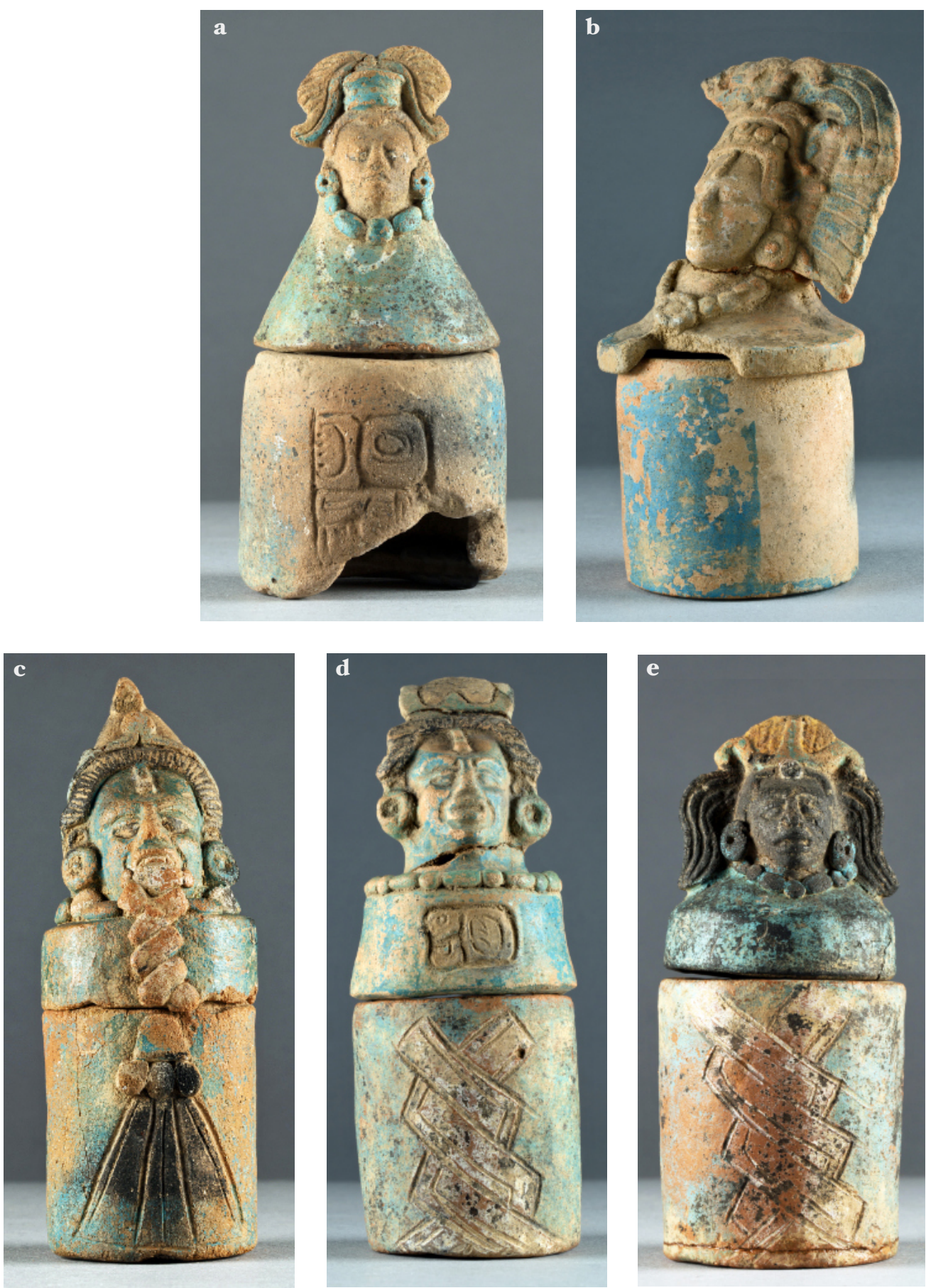
According to Maza García (2019:173-204), there are three types of relics: domestic relics related to a lineage, relics related to gods or founding ancestors, and relics from sacrificed captives associated with war trophies. By preserving the bones of their ancestors over time, the living family members maintained their rights to material property, especially the land owned by their ancestors. Their presence should be ritually kept within the houses or lands belonging to their living descendants (McAnany 1995:49-50, 65; Vogt 1970:I153; Welsh 1988:193-97, cited in Maza García 2019). ${ }^{50}$

Relics associated with war trophies were individually preserved by the warrior as evidence and memory of his feat achieved in battle; for example, stripping the warriors of their weapons and their badges "together with the little finger and the little toe" (Título de Totonicapán [1554]. Carmack and Mondloch I983:178).

According to Bassie-Sweet (personal communication, 2019), lidded vessels most often represent portraits of ancestors, and they often have a mat-sign on their base (Figure $37 \mathrm{C}^{-} \mathrm{e}$ ). ${ }^{51}$ The vessels are effigies of the ancestor, and whatever materials were placed inside were likely relics related to the ancestor. These are thematically parallel to the wood and jade mosaic vessels recovered from Tikal Burial II6 and Burial 196 (see Annex 4, page 14I). ${ }^{52}$

The Chich'en collection includes 2 vases decorated with incisions on both sides, one is shown in figure $38 \mathrm{a}-\mathrm{b}$. The other will be discussed on pages $65-66$. There are also 3 plain lidded vases, II vessels without decoration or paint, other fine decorated pottery with modeled effigies, and broken molded figurines (Figure 39).

The diversity of style and manufacturing quality of the artifacts may indicate that these were objects of exchange or ritual offerings that could have come from different places and periods. A selection is shown in figure 40.

Figure 38. Vase decorated with incisions on both sides.
(a) Portrait of God K'awiil;

(b) Portrait of a sitting lord.
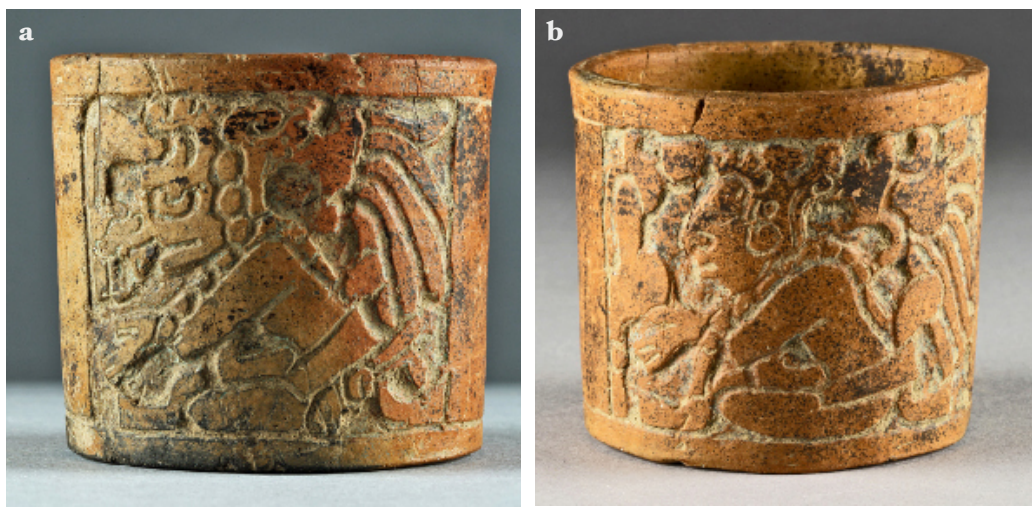

Figure 39. Ocarina (fragmented). It illustrates a personage (an old deity or a dwarf?), possibly carrying another personage on his back.

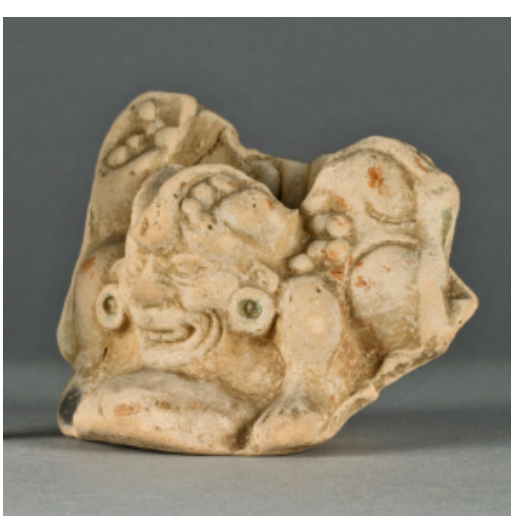


There, nevertheless, remain many open questions, one of which concerns the quality of the pottery. Certainly, the luxury appearance of these artifacts, their polychromic and iconographic elements, as well as the hieroglyphic inscriptions, reveal that the makers were using the techniques and knowhow of the Classic period, without reaching the level of excellence of the artisans from the large centers of the Lowlands. The polychrome lidded pots, for example, had a purpose and a deep symbolic meaning. Their manufacture was most likely intended for the burial mound. These artifacts could, thus, have not been the result of accidental trading with the Lowlands, but they may suggest the existence of a long ceramic tradition in Chich'en. In I949, A.L. Smith (1955:62) reported that Chich'en was still a ceramic producing center.

Figure 40. A selection of pottery from Chich'en.
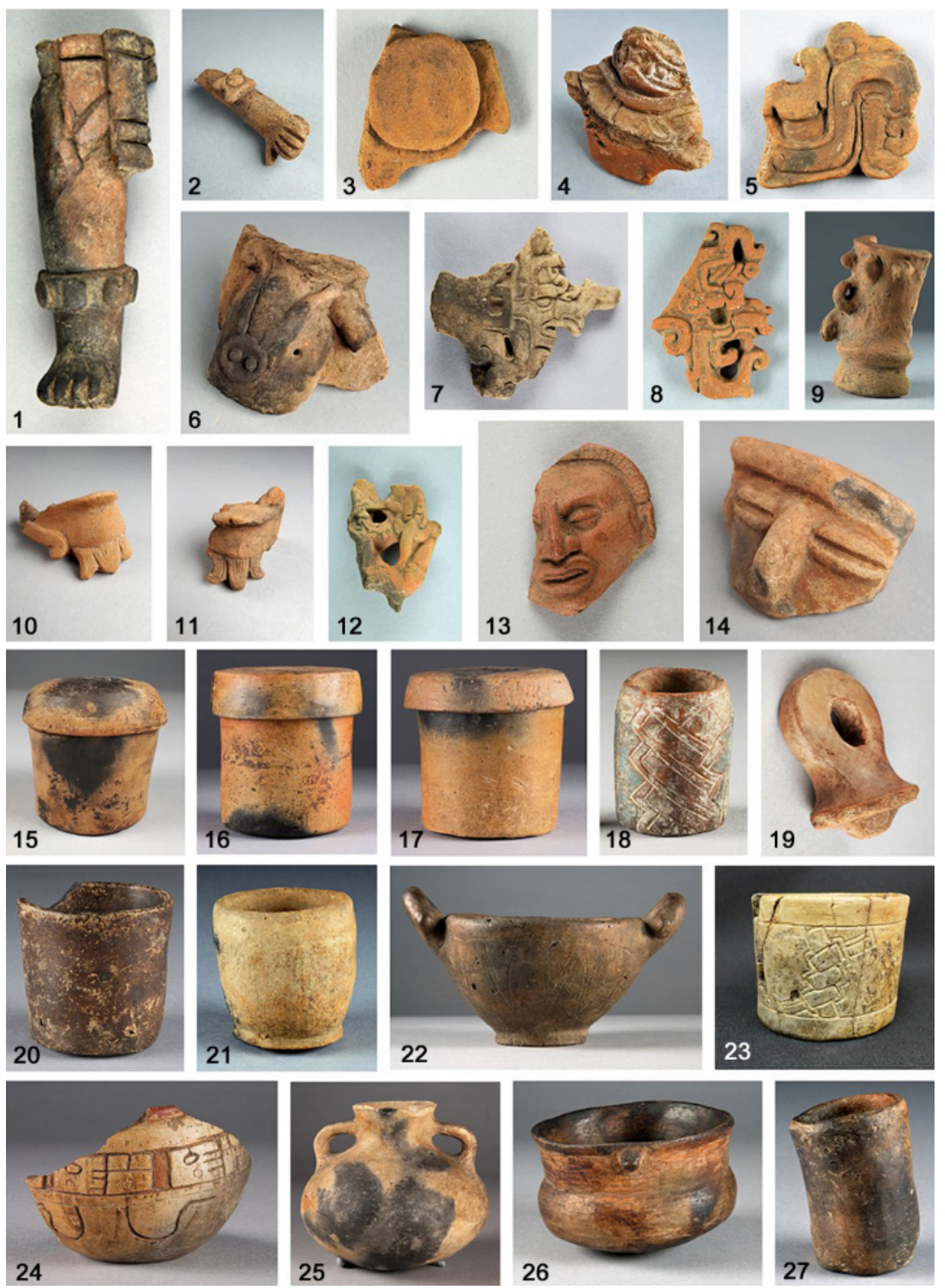


\section{REPRESENTATION OF ANIMALS}

Some pottery fragments and small vessels (censers?) represent animals (Figure 4I). Most of these are nocturnal animals or can be associated with the underworld or mythical tales: jaguar (d), puma (c), snake (a), centipede? (b), dog (f), fox or coyote (e), crocodile (g), tepezcuintle (Cuniculus paca) (h), armadillo (Dasypodidae) (i), monkeys ( $\mathrm{j}, \mathrm{k}$ ), and a vessel with bird's feet and wings (l), that possibly had a head as a lid. These animals were feared and respected and were also considered to be creatures of shamanic transformation. The small vessel (m) shows a throne, stairs and two birds (headless) posing at the sides, probably owls, which, according to the Popol Vuh, played an important role as messengers of the lords of the underworld.

According to contemporary Q'eqchi' beliefs, Tzuultaq'a is the owner of the land's wealth and water sources. He is potentially dangerous because he is also the master (owner) of wild animals.

Figure 41. Representation of animals.
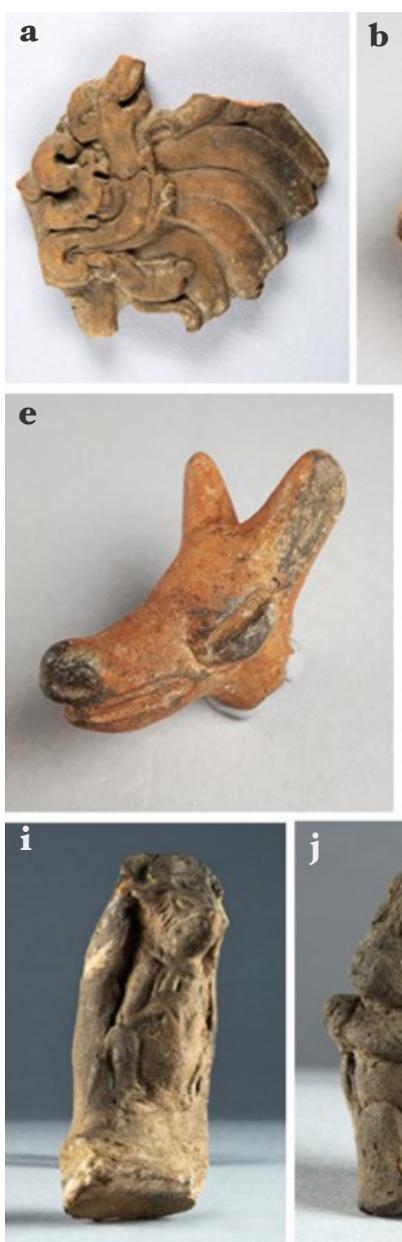

b
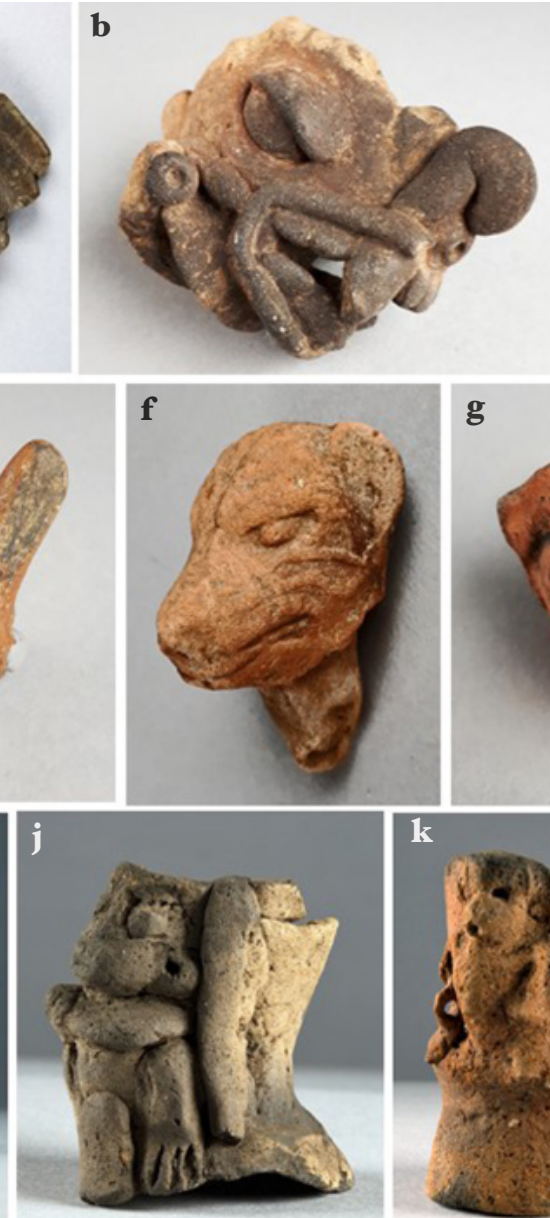

g
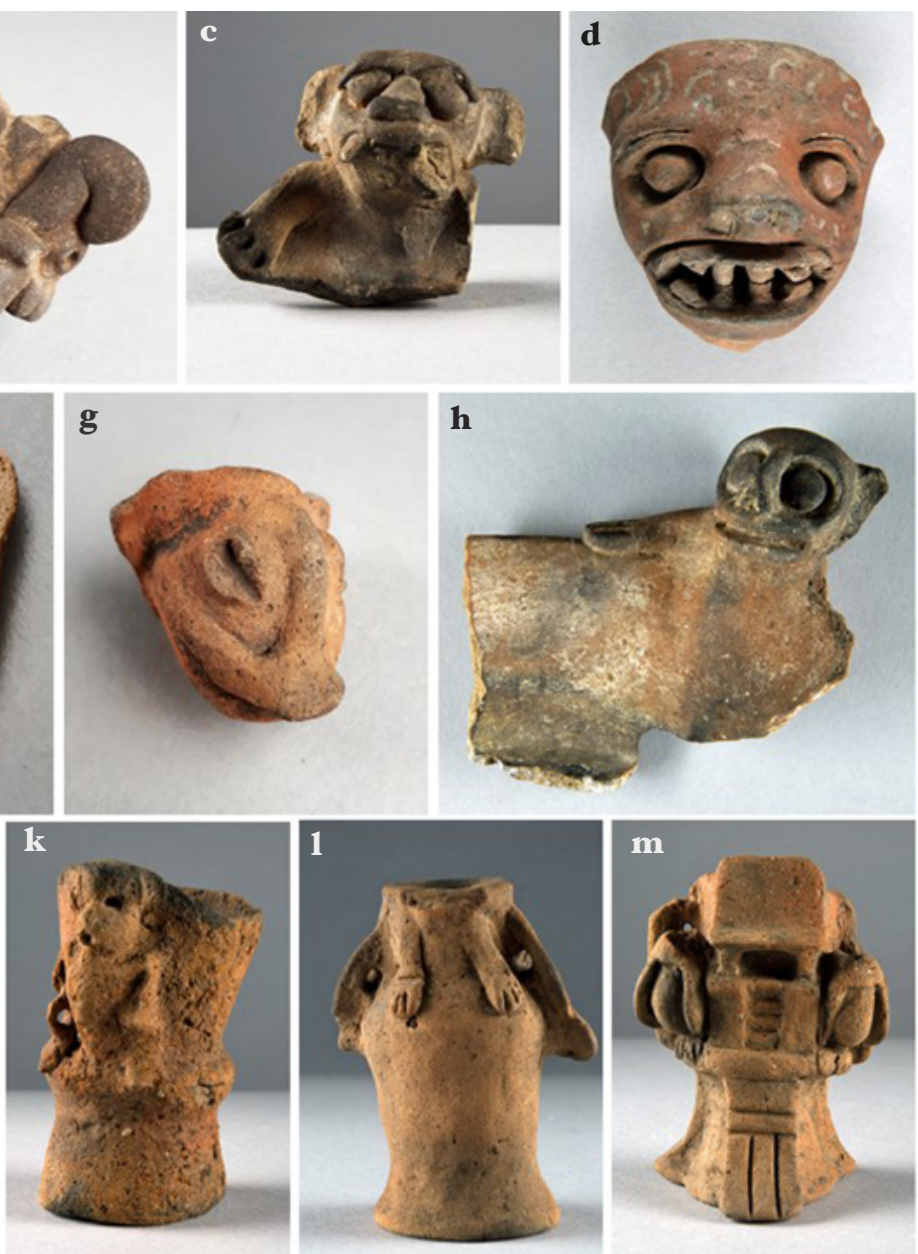

h
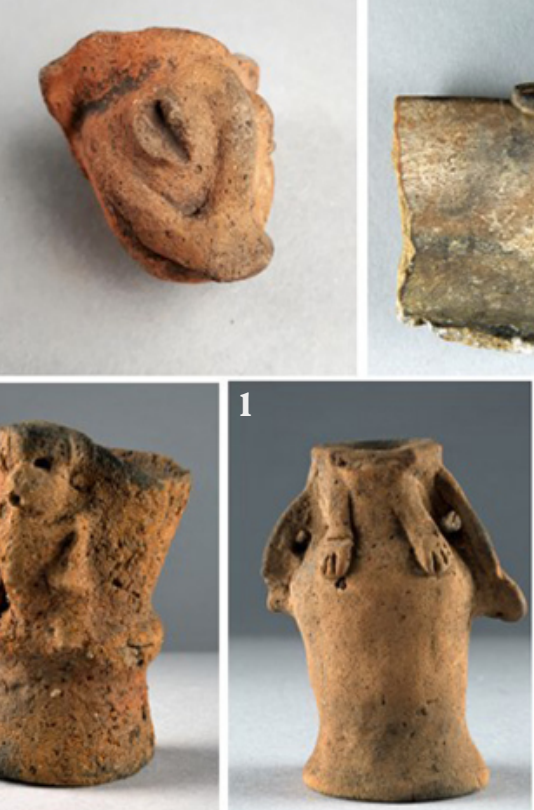


\section{LITHIC OBJECTS (SILEX, SERPENTINE, OTHER STONES) AND OBSIDIAN}

In addition to the jadeite necklace and the stone sculpture, the Chich'en collection also includes silex artifacts (knife, spear and arrowheads), obsidian objects (prismatic blades, knives, cores and a small arrowhead made of green obsidian) ${ }^{53}$ polished votive axes made of serpentine stone or another rock type, and a small figurine made of brown stone, polished and carved (Figures 42, 43, 44 and 45 ).

According to Stuart (2010:288-292), the ancient Maya saw an essential animate essence in precious rocks and large stones. Evidence of this concept comes from numerous ethnographic and iconographic sources. More practical axes used in everyday work are primarily made of chert, a more readily available stone material, at least in the Maya Lowlands. Lightning was widely seen as caused by the striking of the stone axe of Chaahk the thunderbolt god, causing the appearance of shining stones. The "strike of Chaahk"was seen as the creative force behind special stones holding sacred qualities. Even to this day, Maya and other Mesoamerican peoples believe that obsidian, jade, and other special rocks that shine and reflect light appear as a result of lightning striking the earth.

The yellow stones shown in figure 42 (GE 80.I4I; 80.I42 and 80.I45 2/2) are, probably, rock crystals (calcite carbonate). Calcite forms from precipitating calcium-rich water inside caverns or on limestone cliffs. They appear in different colors and have patterns within the crystal.

Modified and unmodified fragments of rock crystal have been recovered from a number of caves in the southern Maya Lowlands, suggesting that they were used in ancient ritual. Crystals were considered to be a precious stone and its utilization seems to be restricted to ritual specialists for use in curing and divining. The power of crystals was apparently believed to be derived from the power of the earth so that crystals found in caves, might be considered to be especially powerful (Brady and Prufer I999:I29-144).
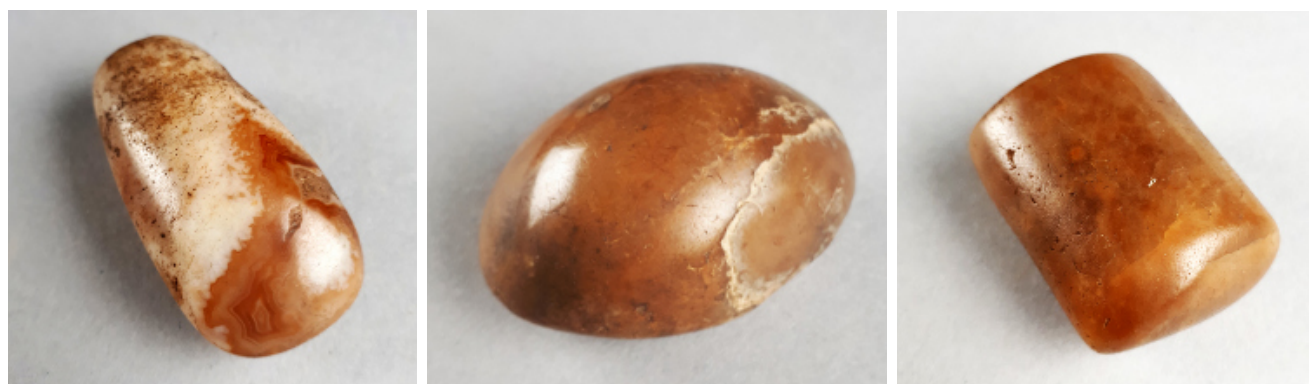
Figure 42.

Silex artifacts (flint, chert or pedernal): spear and arrowheads, knife, and other stones (calcite?).

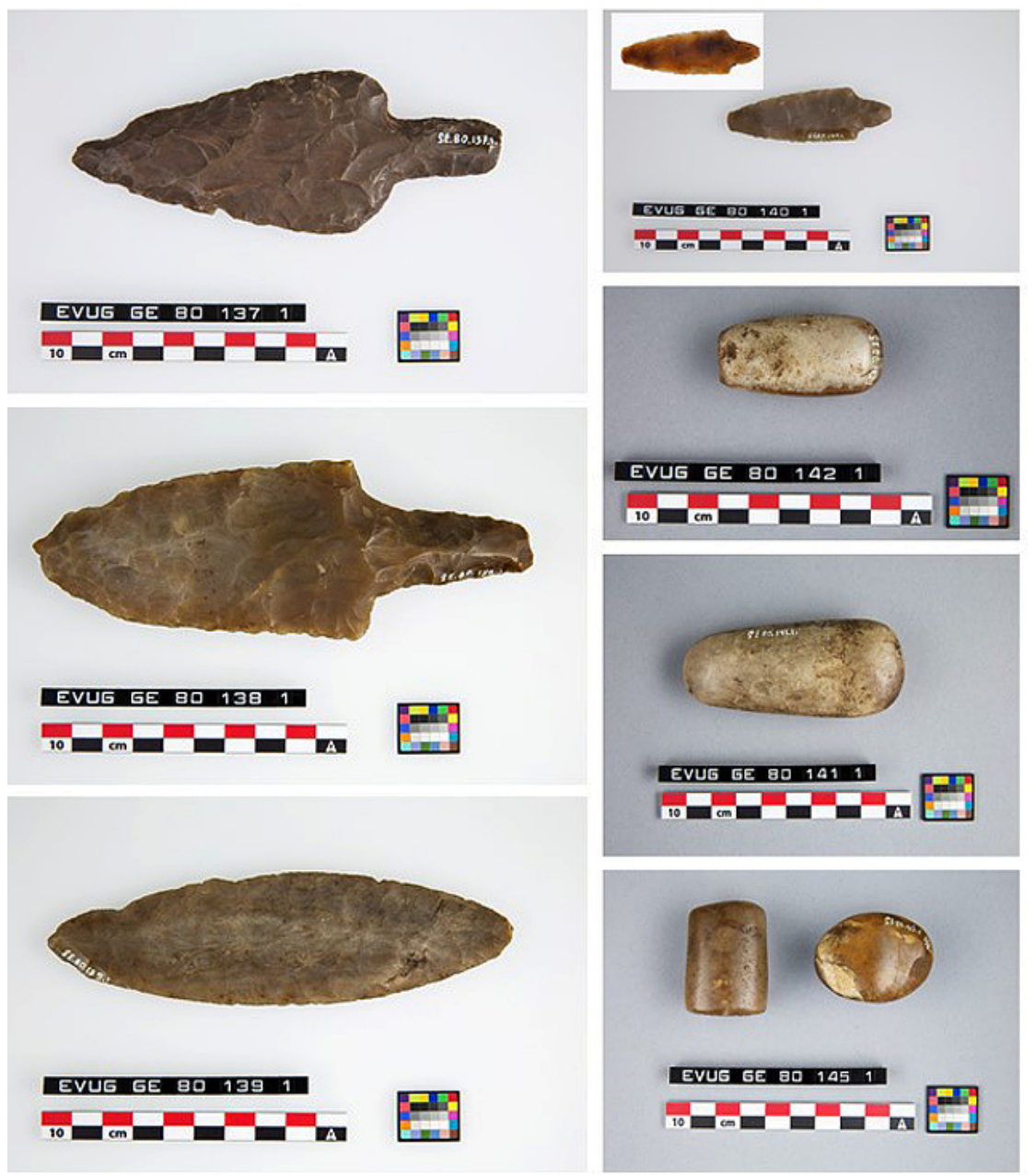

Figure 43. Carved stone figurine.
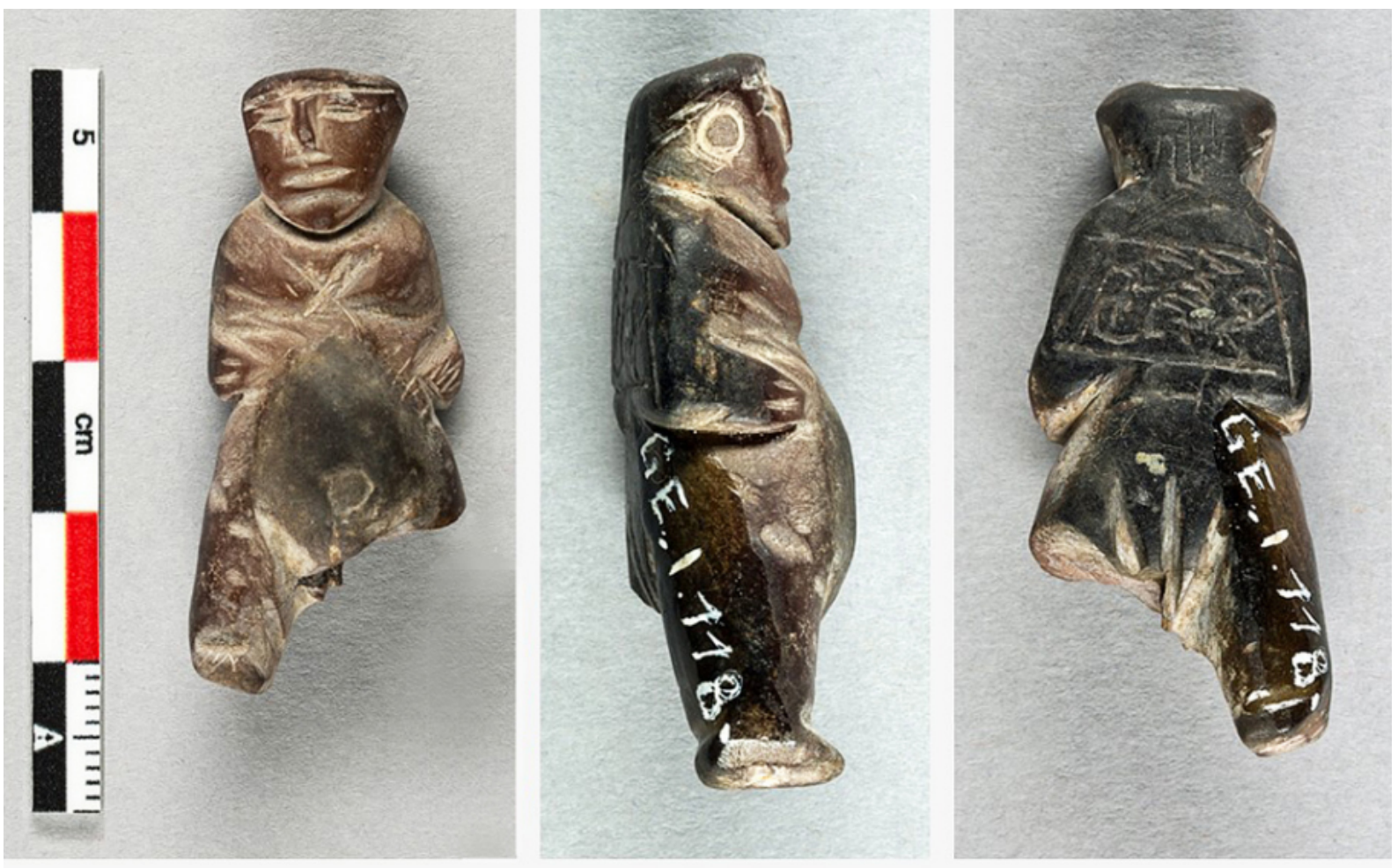


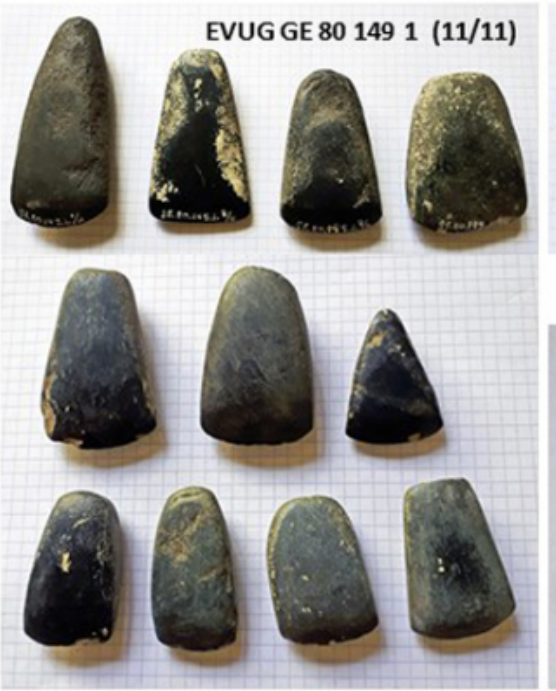

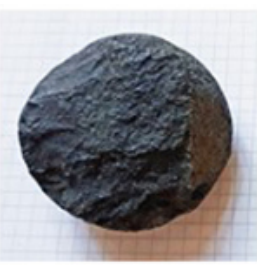

EVUG GE 803551

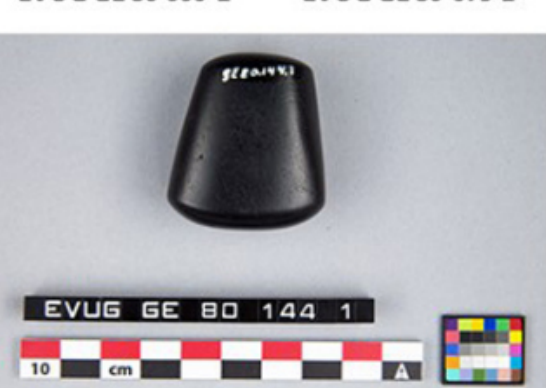

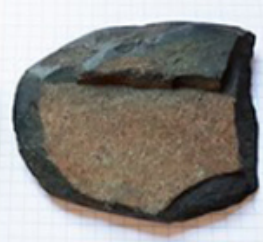

EVUG GE 803791

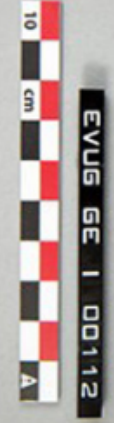

Figure 44. Votive axe heads made of serpentine stone (?), (11/11); 2 round objects, and 2 axe heads made of basalt and other rock-type.

Figure 45. Obsidian objects (prismatic blades, cores, and knives).
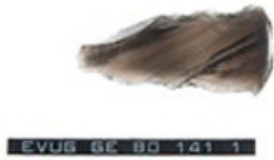

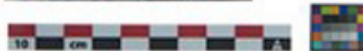
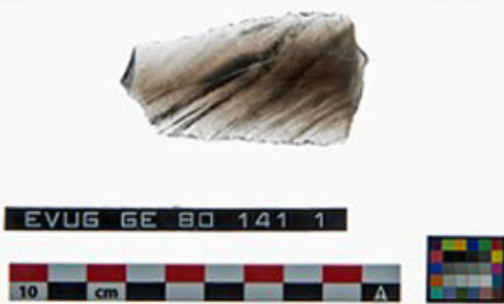

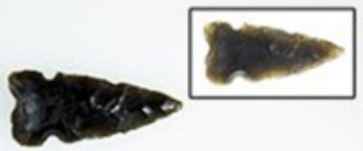

EVUG GE BO 103 I 들
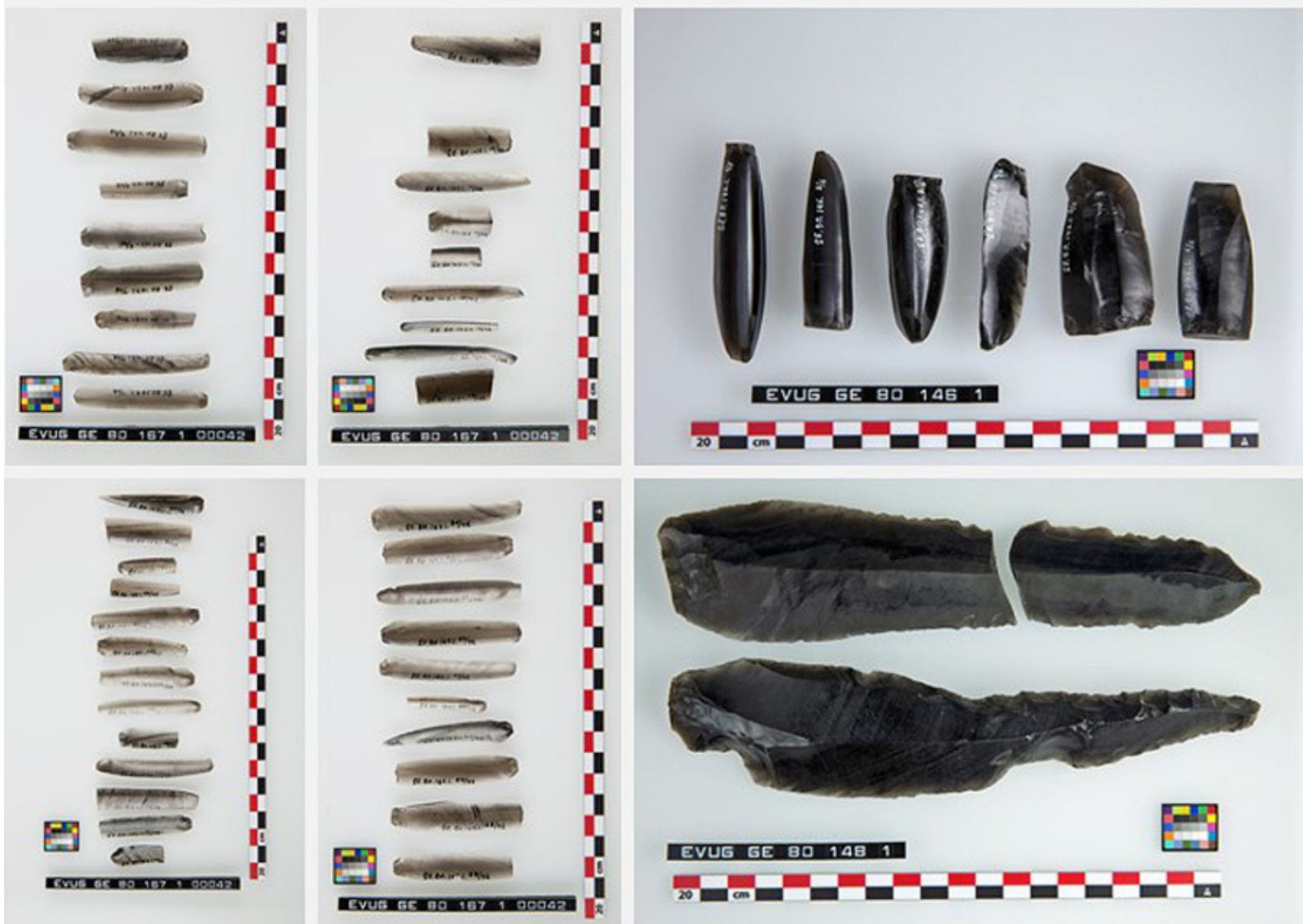


\section{ICONOGRAPHIC \\ ANALYSIS}

\section{REPRESENTATION OF DEITIES ON CERAMICS FROM CHICH'EN}

\subsection{K'awiil}

The incised vessel (Figure 46), and the small head shown in figure $34 \mathrm{~b}$ represent God K'awiil, omnipresent in Classic Maya art. He is an enigmatic and multifaceted deity and one of the principal actors in Maya mythology.

The first identification of K'awiil as God K by Schellhas, in I894, was based primarily on the effigy's protruding snout. His exact nature has puzzled Maya specialists for decades.

The role of God $\mathrm{K}$ as patron of noble ancestry became evident at Palenque, where rulers apparently regarded themselves as being of the lineage of God $\mathrm{K}$, the "snake-footed" deity with the smoking cigar emerging from his forehead (Robicsek 1978:59-113). Representations of K'awiil in Maya art show him in different forms and in different contexts, which makes the understanding of his nature or personality difficult to grasp.

The most characteristic feature of K'awiil is his forehead penetrated by a stone axe head, sometimes taking the form of a burning torch with fire scrolls or a cigar with columns of smoke, the 'smoking forehead.' The substitution between torches and stone axes indicates that the Maya believed thunderbolts could take both forms. The use of a torch in this context emphasizes his association with the fire of the thunderbolt (Bassie-Sweet 2019:49-50).

\section{God K'awiil and sustenance}

K'awiil, has been characterized as an emanation of God Chaahk, the god of rain and storms. He is the personified form of Chaahk's lightning axe, an idea that Miller and Martin (2004:I59) expressed as follows: "for the Maya, this axe was the instrument of the storm-god Chaahk and symbolized his lightning bolt, a combination of stony core, fire, and serpent qualities that finds its fullest personification in the snake-footed character of K'awiil."

Chaahk's axe is generally represented in art and writing with the T24-sign, which in profile, appears as a blade or celt penetrating the forehead of God K'awiil. He embodied Classic Maya notions of agricultural abundance and dynastic procreation. He is related to sustenance and to seeds, particularly maize and cacao seeds (Valencia 2013:227). 


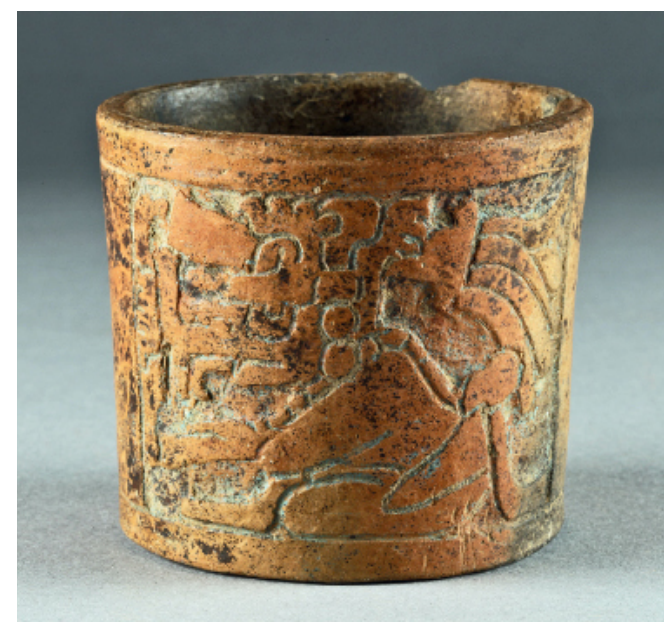

Figure 46. Representations of God K'awiil. (a) Incised vessel GE I 00022;

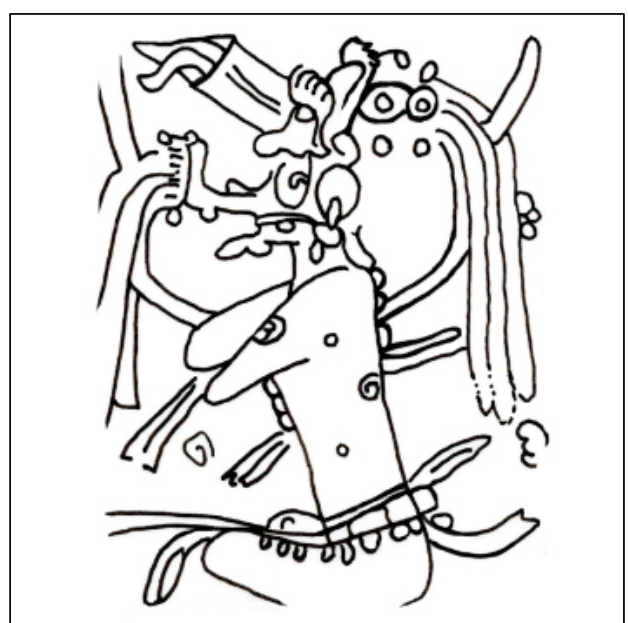

(b) Vessel from Zacualpa.

Stuart (2010:29I-293; fig.I2.5) proposed the reading of the T24-sign as lem, 'bright', 'shiny', or 'flashing' in Cholan languages. This word-sign also means 'light of lightning', 'lightning bolt', resplandor del rayo, relámpago, or literally "Chaahk's flash." Objects marked with this sign are infused with the power of lightning (Figure 47).

"Chaahk's lightning axe strikes the earth at the end of the dry season and supplies the rains that bring forth the green shoots of the sown land. Therefore, axe blades, or celts, seem to have links to maize and fertility and are usually worked in greenstone, such as jadeite" (Miller and Martin 2004:I59).

Figure 47. (a) T24-sign, lem; (b) God Chaahk wielding an axe;

(c) Scepter of God K'awiil with an axe head penetrating his forehead.
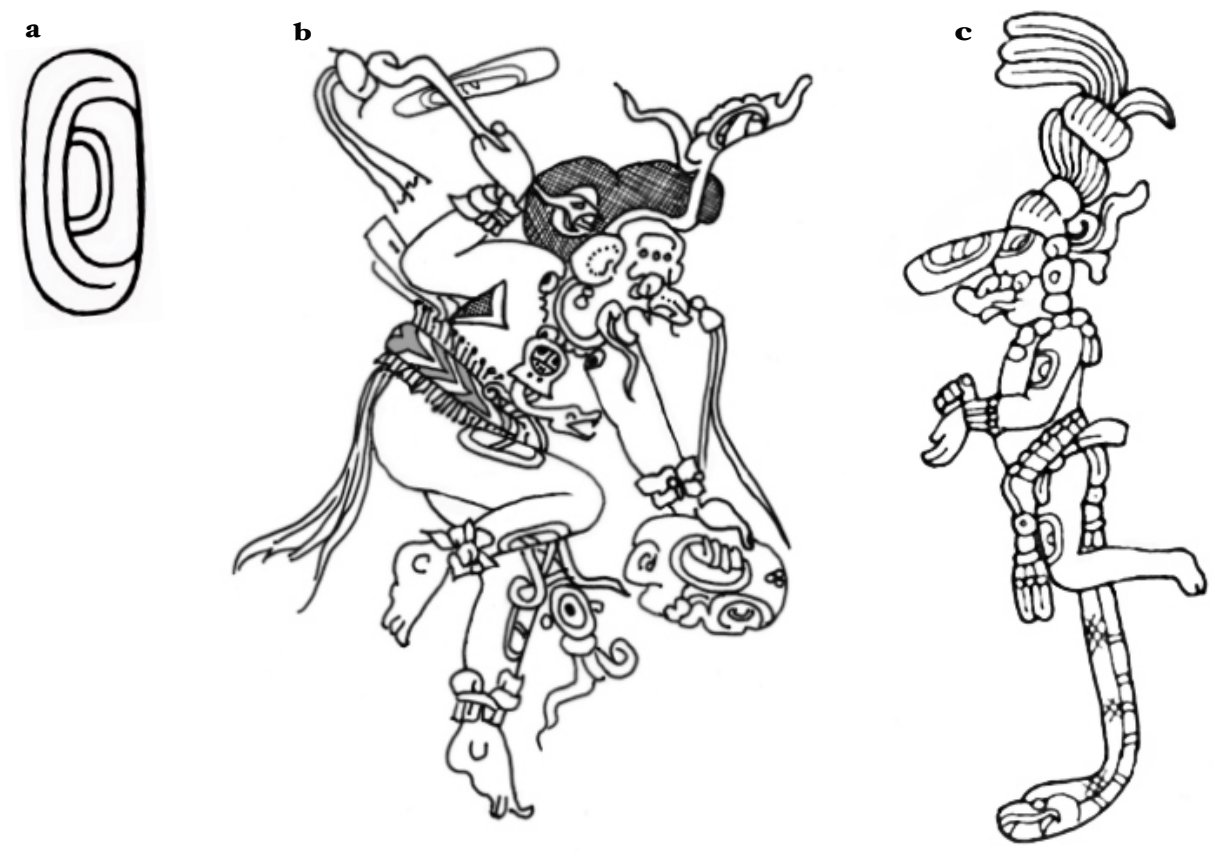
The generative power of lightning is reflected in the Tz'utujil-Maya belief that, when thunderbolts strike the earth, they "charge the earth with lifegiving powers so that whatever is buried within it can rise from the dead" (Christenson 2001:73-74).

In the Popol Vuh, the creation of the earth and the germination of all life is described as a unified effort by a number of gods, all acting in concert after careful deliberation and planning. Among them, there was a triad of lightning bolt deities, known as Huracan or Juraqan, meaning 'one leg,' also called Heart of Sky. Belief in a one-legged god was widespread throughout pre-Columbian Mesoamerica.

While studying the textile designs of huipiles from Totonicapán (K'iche') and San Antonio Aguas Calientes (Kaqchikel), Neutze de Rugg (I976:88; 99) recorded from weavers their understanding of the meaning of a design composed of vertical zig-zag bands: "it is the symbol of Huracan, 'the one-footed one'. He jumps zigzagging in the sky with his foot, drawing the lightning line." 54

\section{K'awiil and kingship}

Appearing on countless relief sculptures, Classic period rulers were portrayed wielding a scepter with the effigy of K'awiil, whose serpent leg served as axe-handle. The serpent was associated with the sky. The scepter was probably made from wood or carved stone. Several examples of chipped flint portraits of K'awiil have survived (Stone and Zender 20Ir:49). Many rulers linked the name K'awiil to their own. The god's name referred to his unique nature as the essential power of the sky, and by using the T24-sign in different elements of their outfit, especially on loin cloths and headdresses, the ruler is portrayed as the embodiment of the lightning bolt. When he accesses the throne and holds the K'awiil scepter, he is literally commanding the power of the thunderbolt (BassieSweet personal communication, 2019). The scepter is a symbol of his legitimacy and his power to control natural phenomena for the sake of his community (Figure $47 \mathrm{c}$ ).

Numerous sources indicate that there was an ancient pan-Mesoamerican belief that humans possessed co-essences, often referred to as companion spirits (Foster 1944; López Austin 1988; Houston and Stuart 1989; Grube and Nahm 1994; Furst 1995, cited in Bassie-Sweet 2019). These co-essences could take the form of animals or natural phenomena like thunderbolts, whirlwinds, and meteors. The alleged power of leaders to mobilize such natural forces was especially valued during periods of war. Classic period rulers and other elite members were thought to have thunderbolt co-essences (Bassie-Sweet 2019:38-39).

The identification of leaders with lightning was also recorded at the time of the Spanish invasion in the Postclassic Lacandón Ch'ol community of Sac Bahlán. The community leaders were said to transform into lightning during the wayeb rituals (Tozzer 1912:504, cited in Bassie-Sweet 2019). 

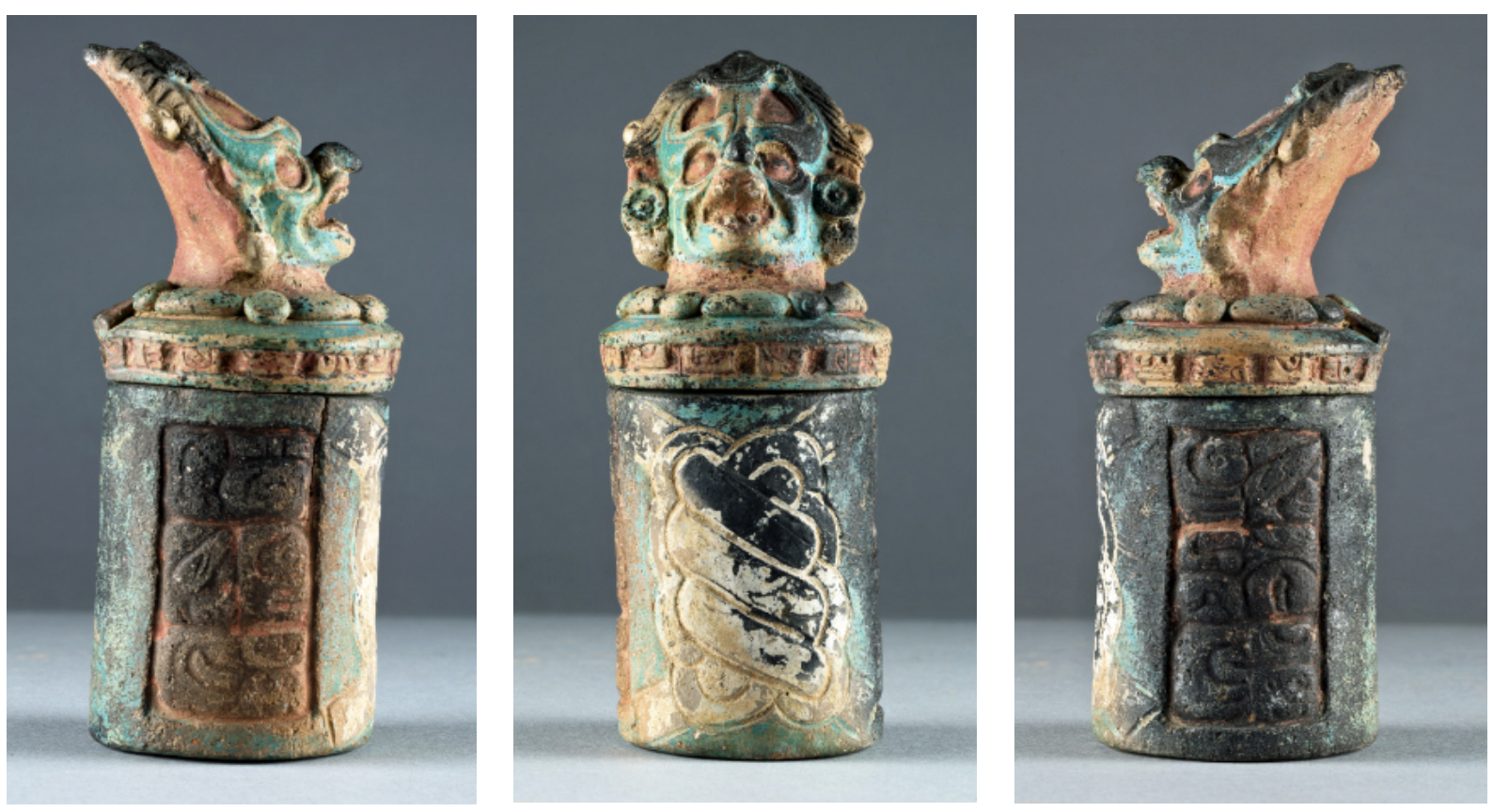

Figure. 48. Lidded vessel GE I 00044 with a representation of God K'awiil with avian features.

\subsection{K'awiil / Itzamnaaj?}

Vessels GE I ooo44 and ooo45 (Figure 48 and Figure 5I) were found inside the sarcophagus and possibly date from the time when the funerary pyramid was built, or when the burial took place. They may, thus, be dated from the Middle Classic period.

According to Valencia (personal communication, 2016), there are reasons to identify the supernatural beings on both vessels as representations of God K'awiil in two different versions. The author focuses on the 'mirror'- symbol on their foreheads (axe head T24-sign or lem?). This symbol can also be seen on the artifacts shown in Annex 4 (photos I, 7, 9, I0, I4, and I7).

The absence of the axe head or torch penetrating their foreheads, the main feature of K'awiil, could be an evolution in the ceramic style, or a specific trait of the ceramic tradition of Chich'en. According to Stone and Zender (2011:49), K'awiil's attributes became simplified in Postclassic art. Rarely seen are his forehead torch and serpent leg, while dramatic emphasis was placed on an upturned, ornate snout. Less a patron of dynastic rituals, K'awiil's role in agricultural fertility came to dominate his Postclassic persona.

The head on vessel GE I ooo44 shows the 'mirror-sign' on his forehead and a round object on top of it, like a jewel. He has a black bird's beak replacing the common protruding snout of K'awiil and has short feathers around his head. These bird features point to the avian nature of the portrayed deity. Curiously, he also shows a lower jaw, and teeth, characteristic of mammals, not birds. In addition, the vessel has hieroglyphic inscriptions on both sides and around the lid, and in the front, it has a prominent jal-sign or mat-symbol, which will be analyzed later. 
The vessel's strange features may be explained by the merging capacities of God K'awiil with other gods such as God Itzamnaaj. The name Itzamnaaj-K'awiil, for example, appears not only during the Classic, but also in colonial sources; their interaction leads to the creation of the corn seed (Valencia 2013:227). Itzamnaaj is one of the most frequently depicted gods in the Maya pantheon and is, without doubt, the most important. His dual role as creator god and overlord is amply attested in art (Stone and Zender 20II:47). One of the essential duties of Itzamnaaj, as priest/diviner, was to perform ceremonies to ensure adequate rainfall. The most interesting aspect of the creator grandfather was his bird manifestation based on a laughing falcon (Herpetotheres cachimnans), known as guaco. Contemporary beliefs about this bird's rainmaking abilities are widespread and consistent in the region because of the dominant role played by the creator God Itzamnaaj, paternal grandfather of One Ixim/One Ajan, the Maize God (Bassie-Sweet 2008:I33).

Itzamnaaj's manifestation as a supernatural bird, known as Principal Bird Deity (Figure $49 \mathrm{a}-\mathrm{b}$ ), is illustrated in Maya art wearing the blue-green diadem jewel, the ak'bal-sign for "night" and "darkness" (a), also infixed in his flower headdress (b). $\mathrm{He}$ also wears a jade celt pectoral represented by a T24-sign (Bardawil 1976; Hellmuth 1987; Taube 1992; Stone and Zender 2011:47; Bassie-Sweet 2015:Ir6).

Initially, we interpreted the 'mirror'-symbols on the foreheads of the deities represented on vessels GE I ooo44 and ooo45 to be the $a k^{\prime} b a l$-sign, a feature of Itzamnaaj's flower headdress or diadem. ${ }^{55}$ This symbol may, however, be identified as the T-24-sign, which represents K'awiil's axe, that contrary to the ak'bal-sign, means "brightness".

In both vessels, two T24-signs are placed as mirrored images, like the 'unfolded' image of an axe head, reinforcing the identity of these deities as God K'awiil. The avian features of the head on vessel GE I ooo44 make him, nevertheless, strikingly similar to the bird manifestation of Itzamnaaj shown in figure $49 \mathrm{~b}$. In this respect, Valencia (2010: 76) points out that at the end of the Classic period, God K'awiil was also illustrated with wings, possibly representing his conjunction with God Itzamnaaj, which can explain the ambivalence in the persona of the deity represented on this vessel. In addition to his avian form, God Itzamnaaj had other animal manifestations, such as peccary, opossum, and turtle (Taube 1992:92-99; Bassie-Sweet 2008:127-47).

Figure 49. Representations of God Itzamnaaj in his bird manifestation. (a) Monument from Toniná; (b) Incised tripod, Early Classic.
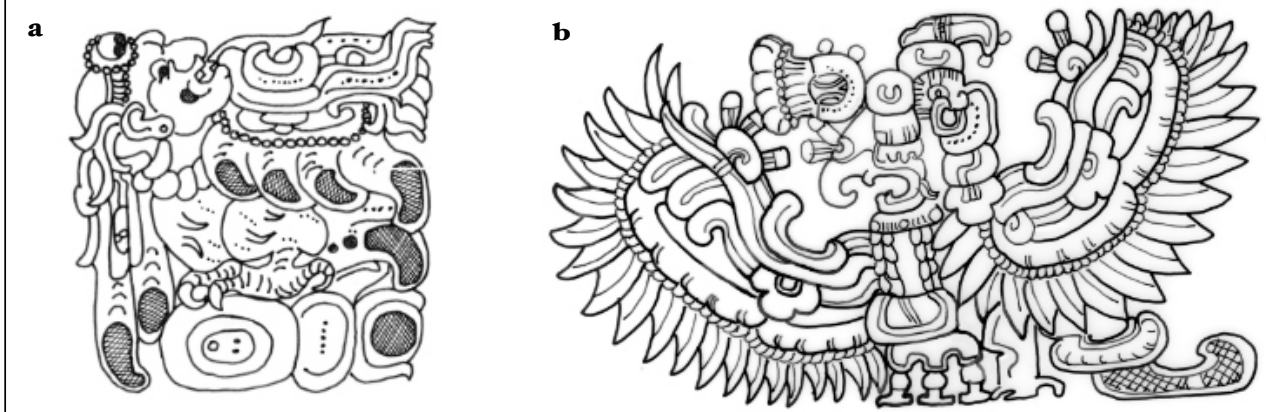

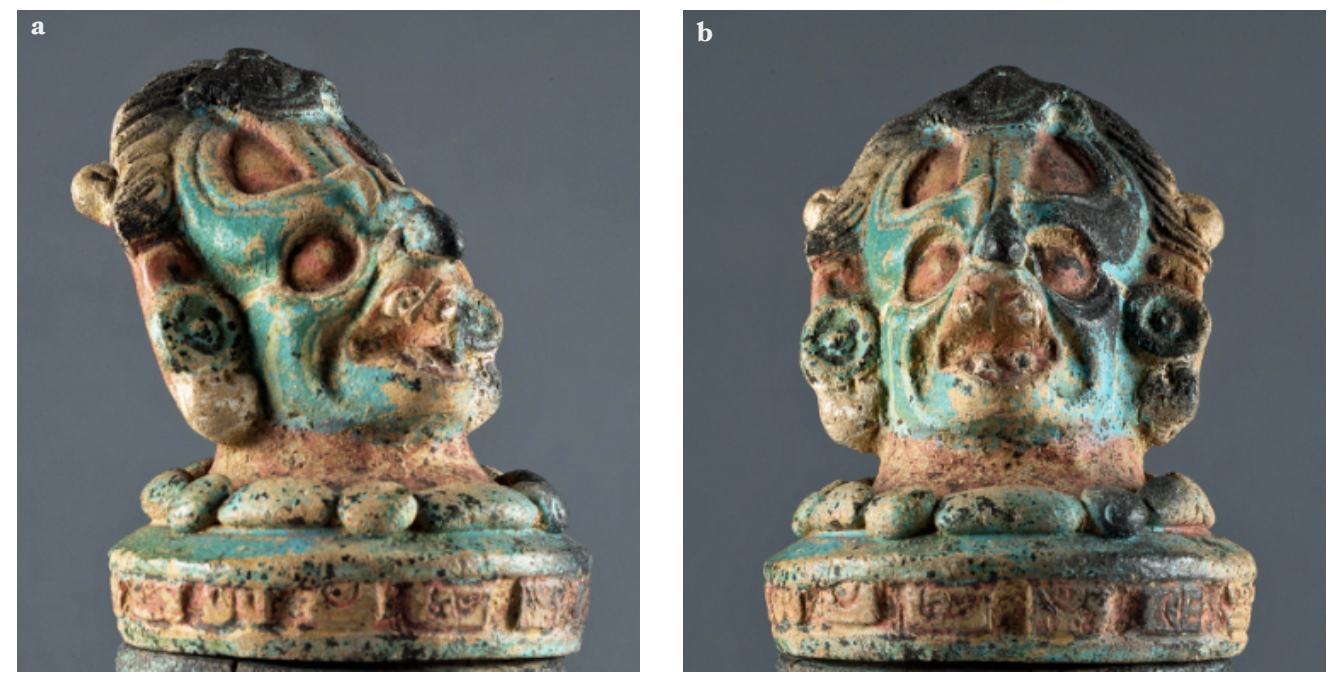

Figure 50 (a - b). Lidded vessel GE I 00044, and head detail.

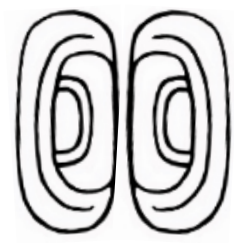

The head on vessel GE I ooo45 (Figure 5I), shows a characteristic peccary snout, hair, beard, as well as the mirrored image of the T24-sign on his forehead crowned by a maize ear. His long protruding snout seems to be in accordance with a description of God K'awiil (Figures $46 \mathrm{~b}$ and $47 \mathrm{~b}-\mathrm{c}$ ), but his peccary appearance could also point to a conjunction with God Itzamnaaj. Furthermore, the reference to maize on this vessel is reinforced by similar maize traits in the other lidded vessels and in several broken lid-heads found in Chich'en. The front of the vessel has hieroglyphic inscriptions.

Figure 51(a-c). Lidded vessel GE I 00045.
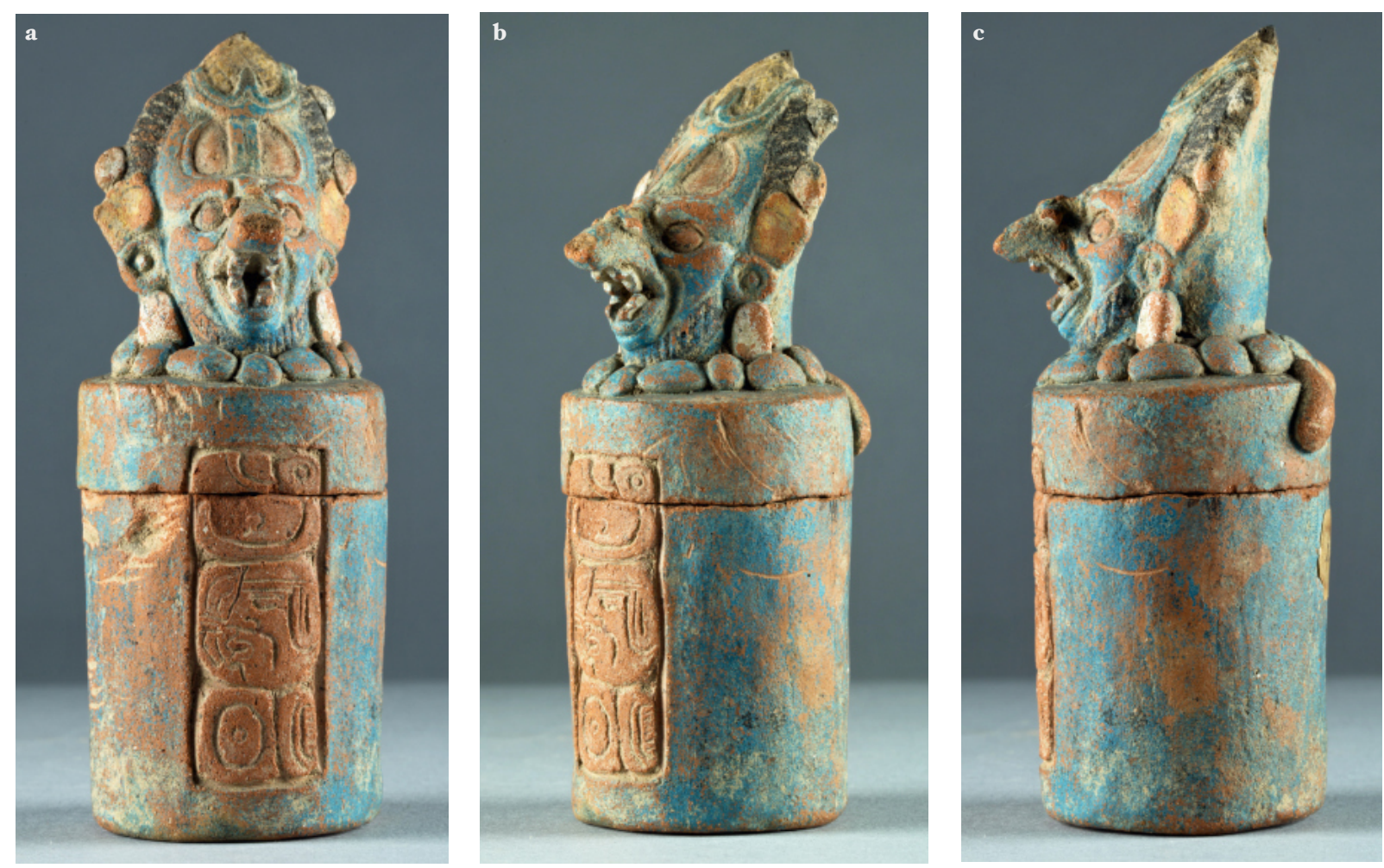

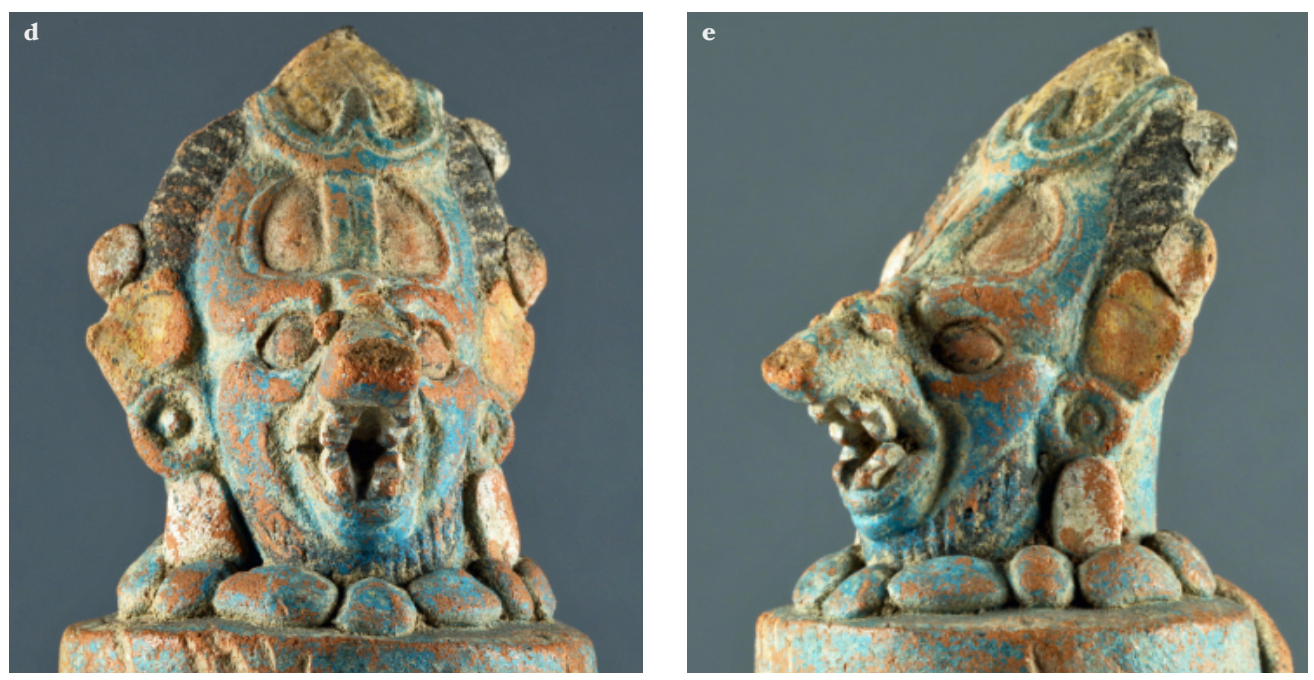

Figure 51(d-e). Lidded vessel GE I 00045, head detail.

\section{Hieroglyphic inscriptions}

For the interpretation of the inscriptions on the vessels shown in figures 48 and 51, we requested the opinion of Rogelio Valencia Rivera, epigraphist, who generously proposed a first interpretation (see Annex 2). In his opinion, the three sentences are strange and seem not very well-made copies of "real" texts, and are not entirely comprehensible. Some hieroglyphs are legible, while others are not. The glyphs on the edge of the vessel lid, figure 5o, are illegible (Valencia, personal communication, 2019). The band seems to be made by means of mold printing or carving.

By the Middle Classic period, ceramics gained popularity and achieved greater elegance. Pottery manufacture remained a regional tradition, clearly framed within the guidelines of the Lowlands. A new decorative element was the inclusion of hieroglyphic bands in which reference is made to the names of the characters present in the scenes they illustrate. In some cases, the cities where they came from are also mentioned. The Mayan region of the southeast and the Motagua valley had a ceramic tradition with its own variants, such as false glyphs or 'pseudo-glyphs', similar to those of the upper bands carved or painted on vessels from the Lowlands (Valdés 1996:I28; 131). Reents-Budet (I994:139) proposed that the function of these bands may be purely decorative and imitative of writing, and that they could serve to "create an effect of high status" in a vessel.

Similar glyphlike bands have been observed on ceramics from Chipoc, a valley site located about a kilometer west of Cobán. They are generally composed of four repeated glyphic signs. The glyphs are incised but the cartouches are left in relief by gouging out the space between the glyphs. This was one of the most used techniques of decoration on Chipoc vessels (R. E. Smith 1952:225). The glyphlike bands are also seen on several cylindrical vessels found at Burial i 96 from Tikal, Petén (Hellmuth 1967:138-I44). The mold GE I ooroo (Figure 5d), in the Chich'en collection confirms this decoration practice. 


\subsection{Jaguar God of the Underworld}

The personage represented on two potsherds from Chich'en (GE I ooo78 and GE I 00107), shown in figure 52, is a deity known as the Jaguar God of the Underworld (JGU). These are probably fragments of tripod bowls that were used as censers, and were found, as offerings, together with many other potsherds, flint, and obsidian objects at Structure 2 of Chich'en. Figure 53 shows two similar exemplars and a censer from this area (Ruta Maya Foundation collection).

The image of the Jaguar God of the Underworld is seen in numerous funerary urns, censers incensarios from excavations in Alta Verapaz and surroundings. This is evidence that this deity, omnipresent in the pantheon of gods and the ideology of the Q'eqchi', was widely spread, not only in the Northern Highlands of Guatemala, but throughout the Mayan area and in other parts of Mesoamerica.

\section{Main features of JGU}

The deity is illustrated in hieroglyphic texts and on war shields with a looped fire cord over his nose as his primary diagnostic trait. In addition to the twisted cord, he shows other distinctive features, such as 'spiral' eyes, feline ears, a highlighted shark-tooth, and a beard-like form hanging from his cheek (Figure 54). His face or, sometimes, only an abstraction of his diagnostic traits, was mostly used as shield decoration or represented on Early Classic effigycensers (Hellmuth i987:367).

Figure 52. Vessel feet with representations of the Jaguar God of the Underworld. a) Rattle-type vessel foot GE I 00078; b) Vessel foot GE I 00107.
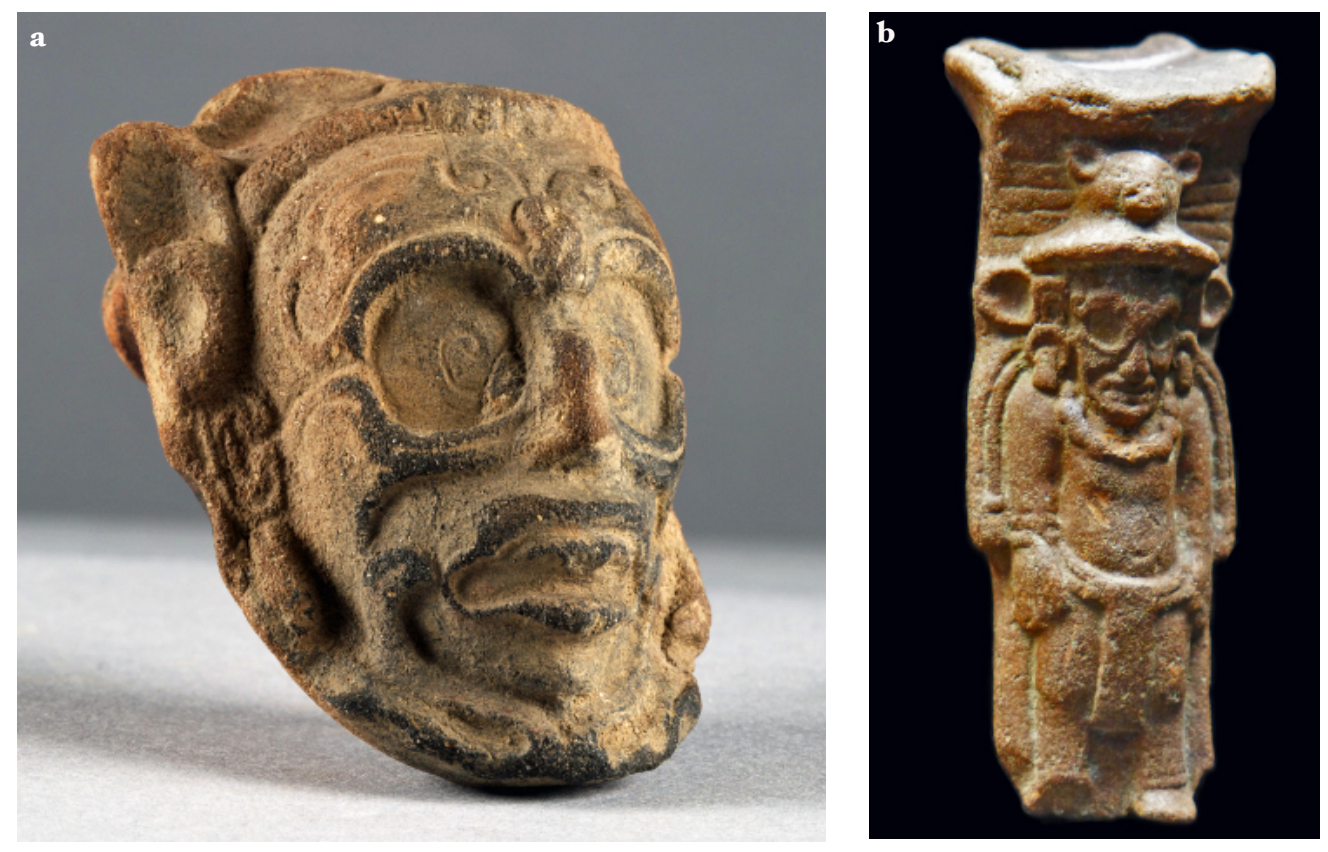

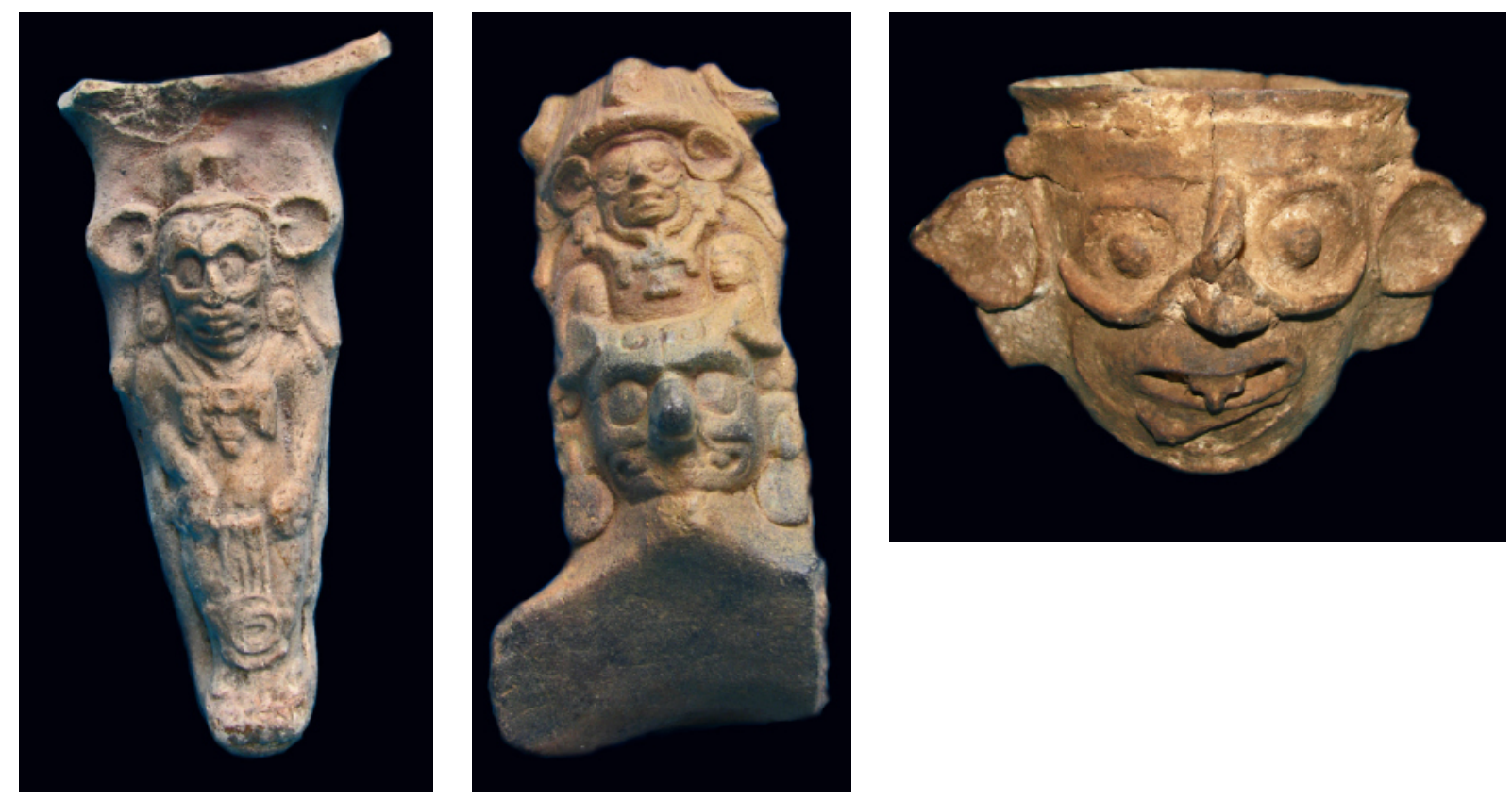

Figure 53. Representations of the Jaguar God of the Underworld. Vessel feet (FRM16.2.5.833 and FRM16.2.5.762), and censer (FRM16.2.5.1116) from unknown sites in Alta Verapaz. Fundación La Ruta Maya Collection.

Figure 54. Diagnostic traits of the Jaguar God of the Underworld: (a) Shield from the Tablet of the Sun, Palenque (detail); (b) Stela 31, Tikal (detail); (c) Yaxchilán Lintel 48 (detail); (d-e) Censers from Chamá, Alta Verapaz; (f) Censer from Panzamalá, Alta Verapaz (fragment).

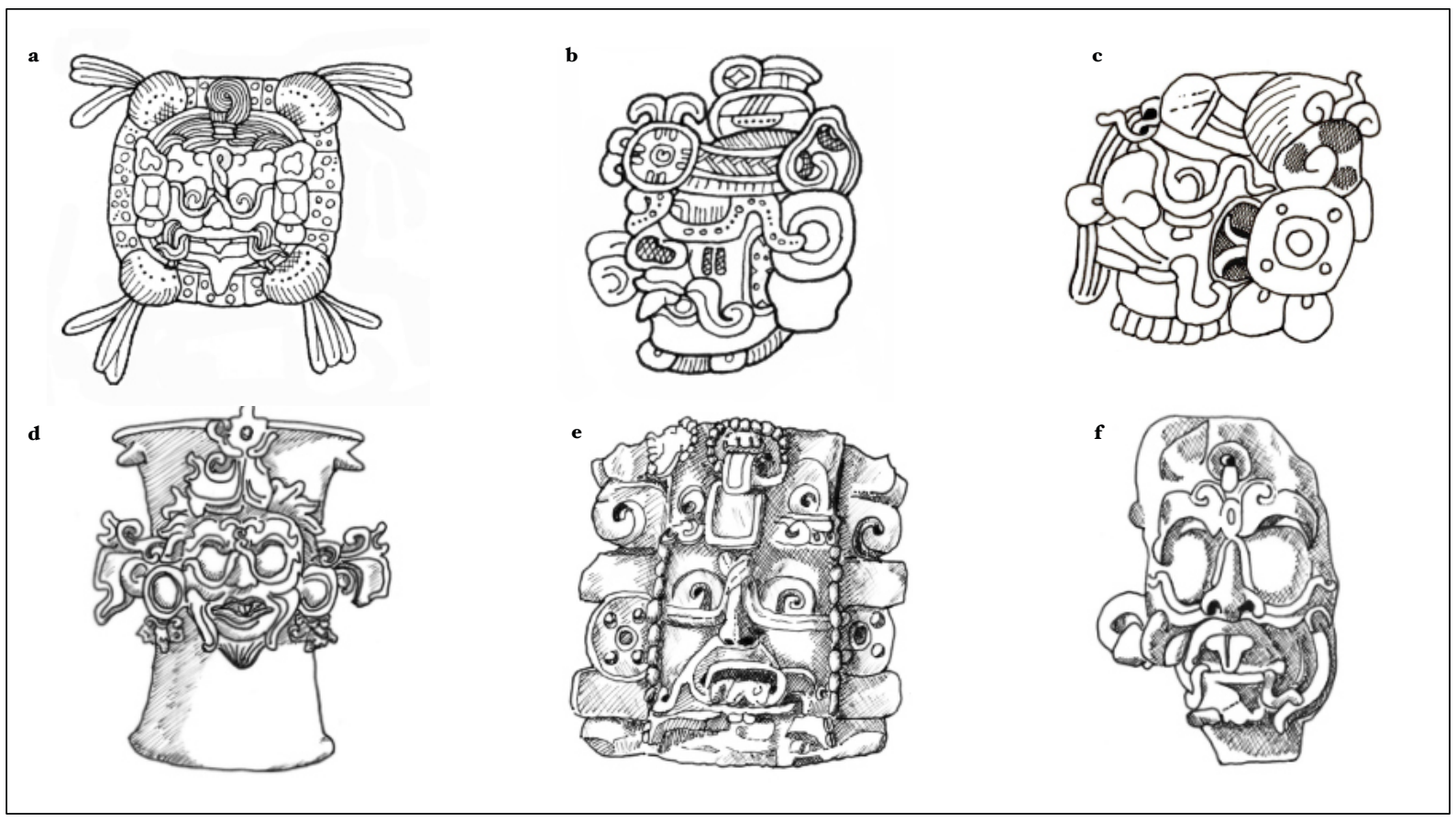




\section{Ceremonial fire}

Evidence of the occurrence of this deity in the Classic period comes from many of the hieroglyphic inscriptions on monuments and architecture that deal with acts of ceremonial burning or censing. These ceremonies were of great importance and remain so today among numerous indigenous communities. In addition, the archaeological evidence of burning rites is the most visible indication of the ubiquity of these ceremonies throughout Mesoamerica (Figure 55). JGU imagery is associated with the fire-drilling ritual, specifically as part of the costume of the rulers who performed these nocturnal rites (Stuart 1998:402-403; fig 26).

Ethnohistorical accounts are fundamental sources for understanding the fire rituals. Perhaps the most detailed of these are Bernardino de Sahagun's records of "New Fire" ceremonies among the Aztec of Tenochtitlan (see page 45). The inscriptions of the Classic period are replete with records of ceremonial burning, which are intimately tied to sacrificial rites and other ceremonies associated with the dedication of buildings and important stations in the Maya calendar. Thus, burning and bloodletting were modes of spiritual and ritual expression, and placing a fire within a new building made it a home by creating a "hearth", thereby investing the space with heat and strength, and with its own soul. The existence of this same ritual in tomb-renewal ceremonies may represent the occasional desire to revivify the muknal, the dwelling of the deceased ancestor. The tomb ceremonies involved more complex actions as well, such as the inexplicable removal and redeposition of bones. Among many modern Maya and other Mesoamerican groups, heat is widely held to reflect the strength or vitality of one's soul (Gossen 1974; Villa Rojas I980; López Austin 1988, cited in Stuart I998:417-4I8).

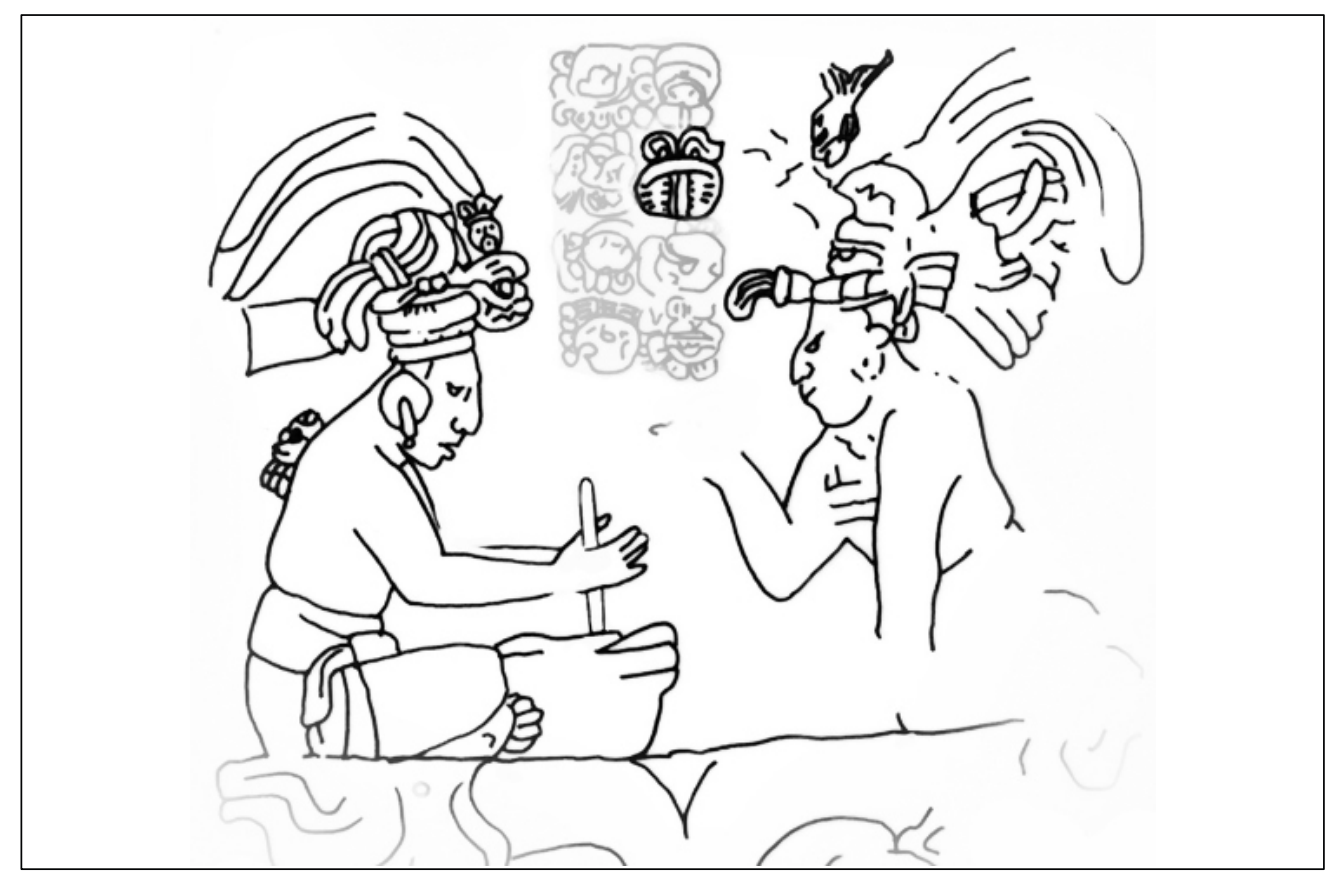

Figure 55. Fire-drilling scene and fire-glyph k'ahk'. Unprovenanced panel (detail). Late Classic. 


\section{War and Sacrifice}

The best known representation of the Jaguar God of the Underworld is the shield in the center of the main tablet of the Temple of the Sun in Palenque, literally supported on the backs of two underworld deities, one of which is God L, the god of tribute and trade. ${ }^{56}$ Named God GIII, he was an aspect of the solar deity, and probably corresponded to the nocturnal sun. His temple was a symbolic cave, a reflection of his vertical placement as the "lowest" of the three temples of the Cross Group (Stuart 2006:88). The temple's hieroglyphic name shows subtle details of a witz "mountain" sign, explicitly indicating the temple as a mountain. The shield is obviously a symbol of war. The theme is quite different from the other two temples of the Cross Group, with their respective emphases on ancestral regeneration and agricultural fertility. Warfare adds a basic element to the tripartite categorization of royal authority. Power derives from ancestry, from the forces of the fertile earth, and also from the duty to conduct war.

Ornate shields also appear on scenes of warrior kings during cave rituals, as we see on Naranjo Stela 2I (Figure 56). The commemorated event at Naranjo is och-ch'e'n, "cave entering". As mentioned above, the temple's sanctuary is a representation of a ch'en, a space that is inside a sacred mountain. "One gets the sense that the Maya associated the power of war with nocturnal and underworld forces" (Stuart 2006:I6I).

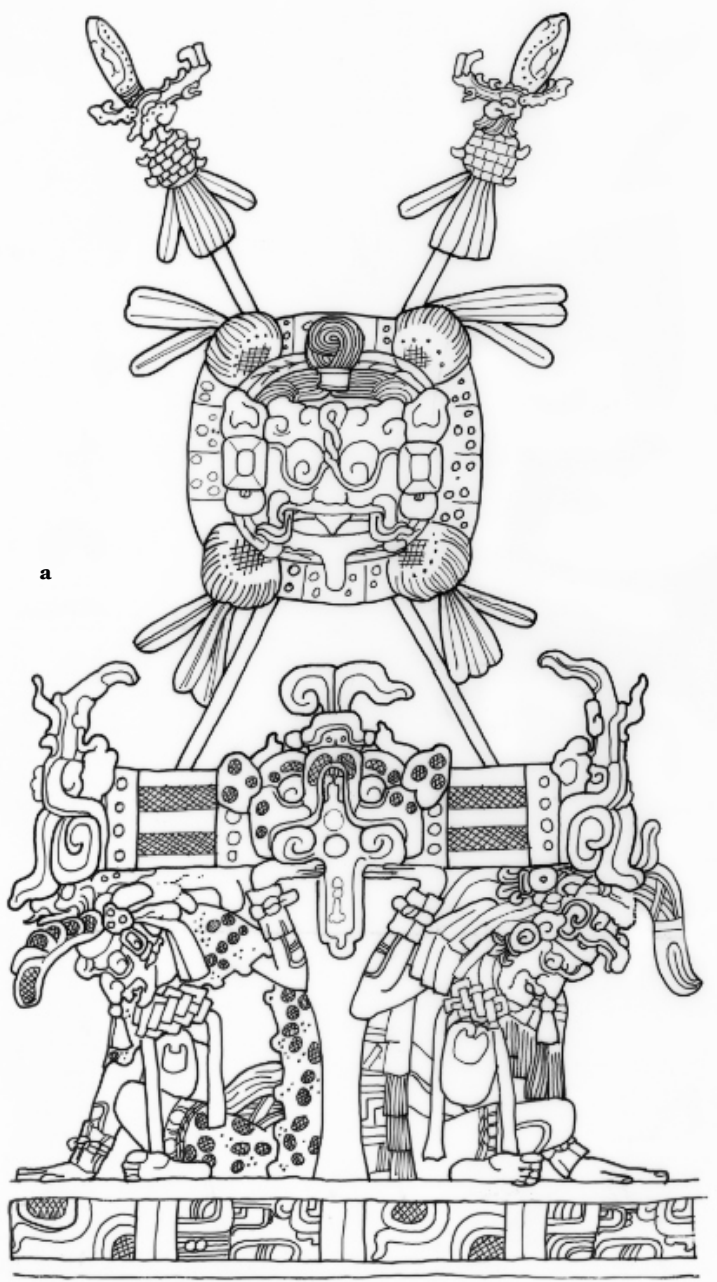

The presence of the Jaguar God in ceramics leads to the myth of the Popol Vuh, which is explicitly related to the origin of the sun, the moon, and the stars. After defeating the lords of Xibalba, the heroes Hunahpú and Xbalanqué ascended into heaven as the sun and the moon. Essentially, war was a divine mandate, necessary to feed the sun and the earth.

Figure 56.

(a) Detail from the

Temple of the Sun Panel, Palenque. Atop the bench are two crossed stone lances and a shield decorated with the face of God GIII (JGU).

(b) Portrait of a ruler in war attire showing attributes of God GIII/ JGU: looped fire cord over his nose and ornate shield.

Naranjo Stela 21 (detail).

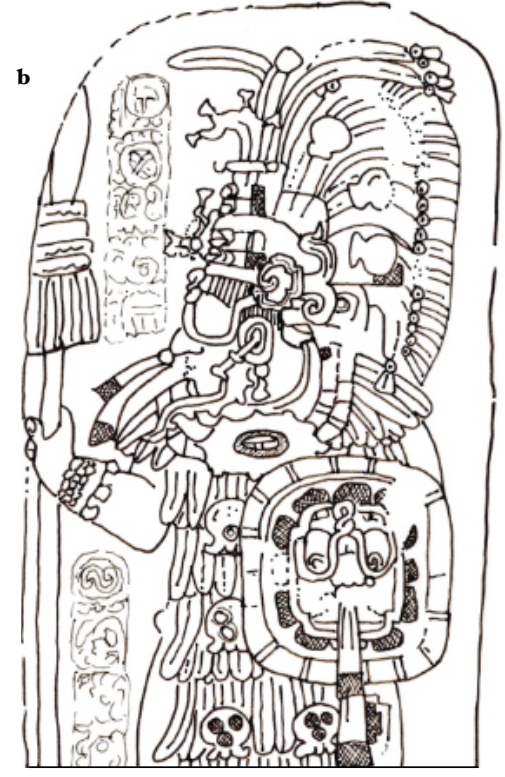


The primal warriors were considered personifications of stars and, at the same time, equated to the spirits of warriors killed in combat or who died on the sacrificial stone, who according to Aztec mythology, were the companions of the sun in his daily transit. Like other ancient peoples, the Maya populated the firmament with a variety of mythological characters, which personified planets, stars, or constellations. They are recognized because they are usually marked with the sign $e k$ ', which means "star" (Chinchilla 20II:I88-2I2; figs; 80-8I).

Undoubtedly the most impressive portrait of the God Jaguar is found on top of the Staircase of the Jaguars in Copán, where his face is flanked by two large $e k^{\prime}$-signs (Figure 57). ${ }^{57}$ This staircase served as the stage for the presentation and slaughter of war captives. The Jaguar God - the quintessential warrior star presided over the presentation and sacrifice of captives on the staircase (see also Chamber 2 of Bonampak, in Chinchilla 20II:194; fig. 84; Hellmuth 1987:367).
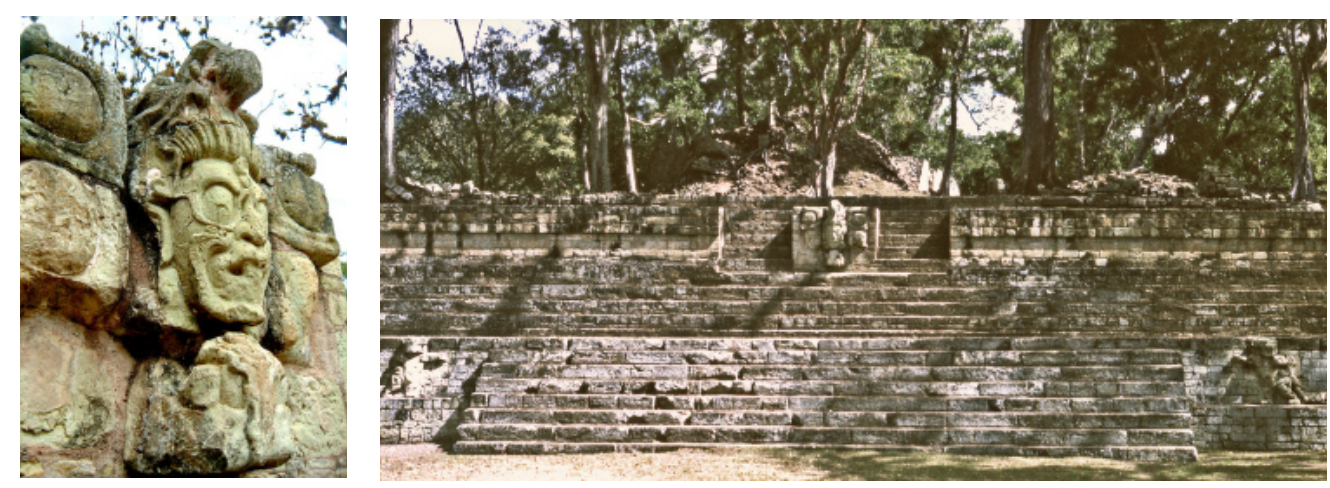

Figure 57. Jaguar God of the Underworld framed by ek'-signs. Copán East Court, Staircase of the Jaguars.

\section{The Jaguar God of the Underworld in Verapaz}

The myth of Sun and Moon, the Story of B'alam 2'e and Qana Po, is central in the Q'eqchi' cosmovision. It appears to be of native Verapaz origin and goes back to Classic times. It is essentially a creation story. It relates the abduction of the Old Earth god's daughter, the creation of the sun and the moon, and explains how the present era came to be. It also deals with the creation of maize. The myth was told by Juan Ka'al, a Q'eqchi' flute-player and drummer, to Pablo Wirsing in 1909 at Yalpemech, near Cancuén. The story is predominantly preserved in Q'eqchi'. Wirsing translates the name B'alam Q'e as Sol Escondido, Sol de la Noche or Faguar Sol (Van Akkeren 2000:232-233). ${ }^{58}$

The name Xb'alam Q'e from the Q'eqchi' myth is the counterpart of Xbalanqué, the second Hero Twin of the Popol Vuh, always mentioned after his brother Hunahpú. Bartolomé de las Casas ${ }^{59}$ describes him as a god specifically linked to Verapaz:

"Over this god called Exbalanquen, they tell that he went to the hell to make war, and he fought with all the people there and defeated them. He captured the king of hell and many of his army. It is said that with the victor of hell the sacrifice of men began." 60 
Xb'alam Q'e, personified by a jaguar, is the Sun of the Underworld, the 'hidden sun'. His identification is complicated by the transformation of the sun of the night into the sun of the day in a single character. It is noteworthy that, unlike the narrative of the Popol Vuh where Hunahpú became the sun, and Xbalanqué the moon, in the Q'eqchi' myth it is Xb'alam Q'e who fulfills the role of the Night Sun, who, at the end of the myth, becomes the Day Sun, and his beloved Qana Po, the moon. In the Xib'alb'a myth of the Popol Vuh, Xbalanqué is the executioner, the fire maker, and the magician. For his twin brother Hunahpú, as Day Sun, the underworld is the place where he succumbs and dies; while for Xbalanqué, the underworld is his natural world, where he reigns and shines like the full moon as the Night Sun (Van Akkeren 2012:126-128). ${ }^{61}$

\subsection{One Ixim / One Ajan, the Maize God}

Ancient Mesoamericans were aware that a flourishing community hinged, as it did for their ancestors, on an abundant maize crop. That maize made their civilization possible is acknowledged in creation myths featuring the birth of One Ixim, the Maize God. Of all plants, maize was one with which the Maya personally identified. Since the Creator Grandmother fashioned the first humans from maize dough, they believed their own bodies were made of maize. ${ }^{62}$ Maize generally came to symbolize all things good and beautiful. Quite literally, the Maya, among other Mesoamericans, worshipped the food that sustained and ordered existence (Stone and Zender 20II:225). One Ixim's name literally means "one corn seed". Each day in the thirteen-day cycle of the tzolk'in calendar was ruled by a different god, and One Ixim was the god of the number one (BassieSweet 2019:278).

One of the diagnostic traits of One Ixim is a jade flower on his forehead, a metaphorical representation of the tassel of the corn plant. He is frequently illustrated wearing a jade-decorated net-like skirt. One Ixim represented not just a mature corn plant, but the quintessential plant that produced the seed corn for future plantings (Bassie-Sweet 2019:278). When the ear reaches its first edible stage, it is called ajan. This green corn is considered a delicacy, and the Maya harvest a small amount of ajan ears for immediate consumption. During the next stage of growth, the ear of corn undergoes internal ripening and hardening. This mature corn is called ixim. During its harvesting, the farmer selects and safely stores a number of large ears so that the seeds can be used for planting the next year's crop. These seeds, ixim, are chosen from plants that have produced only one ear of corn, because such plants produce better quality seed (Kaufman 2003:I034, cited in Bassie-Sweet 2019:50-54).

The likening of maize to the human body explains the persona of One Ixim (Figure 58). On images from the Classic period he appears sometimes as a fully human male figure with plant symbolism restricted to his head, which is elongated and often blossoms into what is essentially the nal-sign. ${ }^{63}$ On stone monuments and sculptures, Stela $\mathrm{H}$ from Quiriguá, for example, (a), the nal-sign rises from 
the crown of One Ixim, merging with his long flowing hair, an allusion to the maize tassel. On reliefs from the Temple of the Foliated Cross at Palenque, he appears as an anthropomorphic maize ear hanging on the plant's stalk (b). This look had such appeal that it was imitated in hairstyles of the nobility, whose upswept coiffure resembles the curled foliage of maize (c). In the Late Classic period, the ancient Maya also used a more rigid, symmetrical stylization of the nalsign, a seed-filled cartouche flanked by leaves (d), that better served frontal representations of maize and was placed on headdresses and necklaces (Stone and Zender 20II:225).

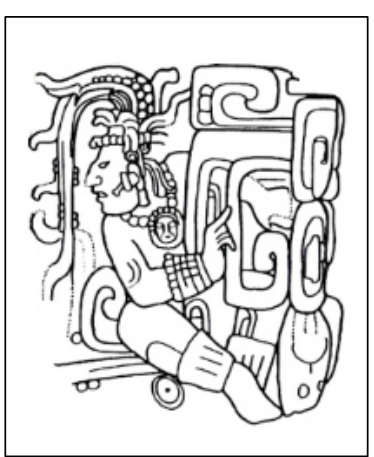

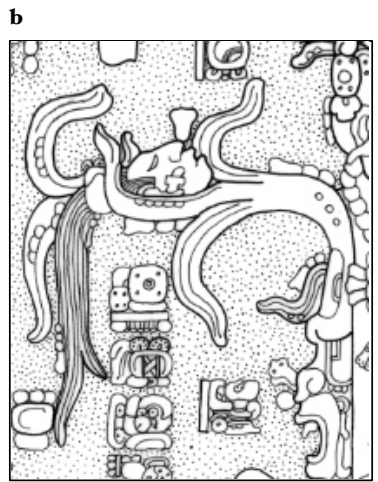

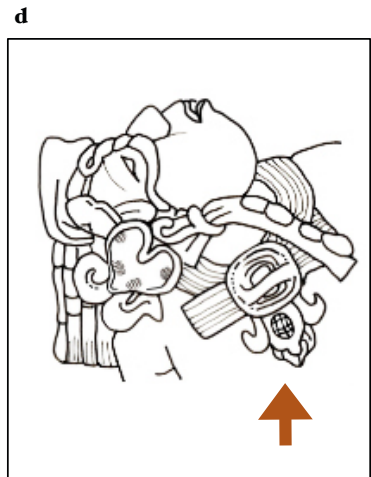

Figure 58 (a) Tonsured Maize God, Stela H Quiriguá (detail); (b) Foliated Maize God, Temple of the Foliated Cross, Palenque (detail); (c) Portrait of K'inich Janaab Pakal of Palenque, with upswept coiffure, elaborate counterweight earflare, and headband like that worn by Itzamnaaj or God D. The associated glyphs spell his name; (d) Collar of a captive with a stylized maize motif. He also shows features of the Jaguar God of the Underworld. Sculpture relief from Toniná (detail), Late Classic period.

During the Late Classic period, two distinct but overlapping representations of this deity emerged. Taube (1985) classified them into two categories: the "Foliated Maize God" and the "Tonsured Maize God". He interpreted these categories as aspects of the same deity, the first representing young, green corn and the second representing the mature corn ear. One Ixim, the "Tonsured Maize God", is presented with a markedly elongated head, often shaved in zones across the flattened brow (Figure 59). He often has an ear of corn sprouting out of his head ( $\mathrm{a}$ and $\mathrm{b}$ ), but he is also shown with a stylized flower on his head representing the tassel of the plant. One Ixim personifies mature and fertile maize (Taube [1985] 2018:76-93; Bassie-Sweet 2000:3-4; 2019:5I).

Figure 59.

(a) Bust of Young Maize God from Structure 10L22, Copán;

(b) Late Classic "Foliated Maize God" holding a bloodletter, Copán Stela H; (c) Maize God (fragment), GE I 000102.
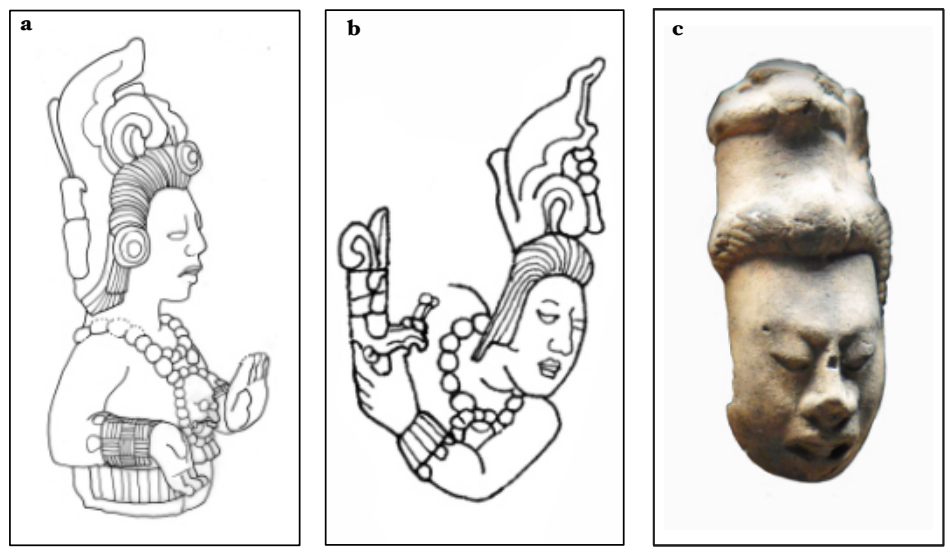
In addition, cranial deformation was practiced during early childhood to lengthen the head, in the style of the deity's head.

The "Foliated Maize God" is portrayed wearing a headdress with corn leaves and represents tender, growing maize (Figure 60). The ceramic heads shown in figure 6I represent One Ixim, with a yellow maize ear and green husks as headdress (see also figure $58 \mathrm{~d}$ ).
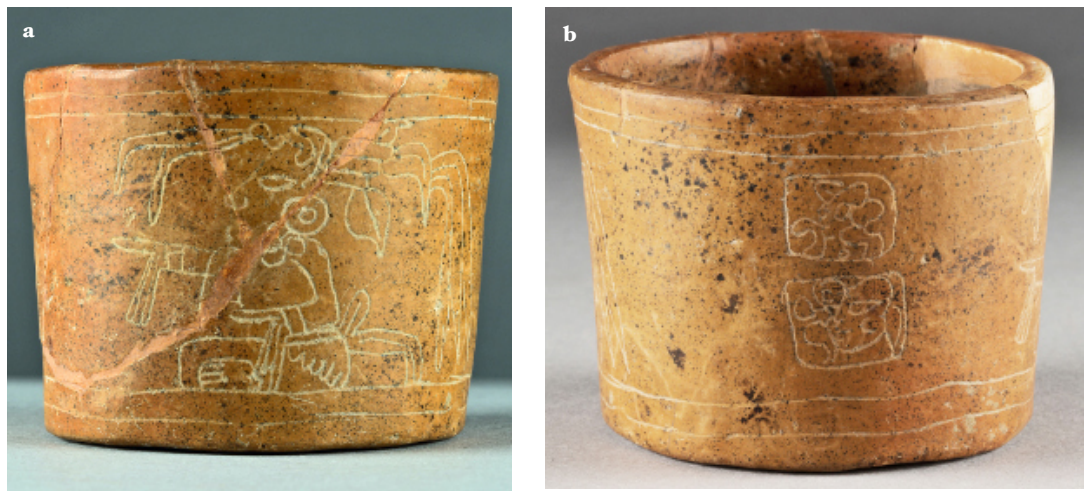

Figure 60.

Incised vase GE I 00018 with the image of the "Foliated Maize God" (face a), and inscriptions (face b).
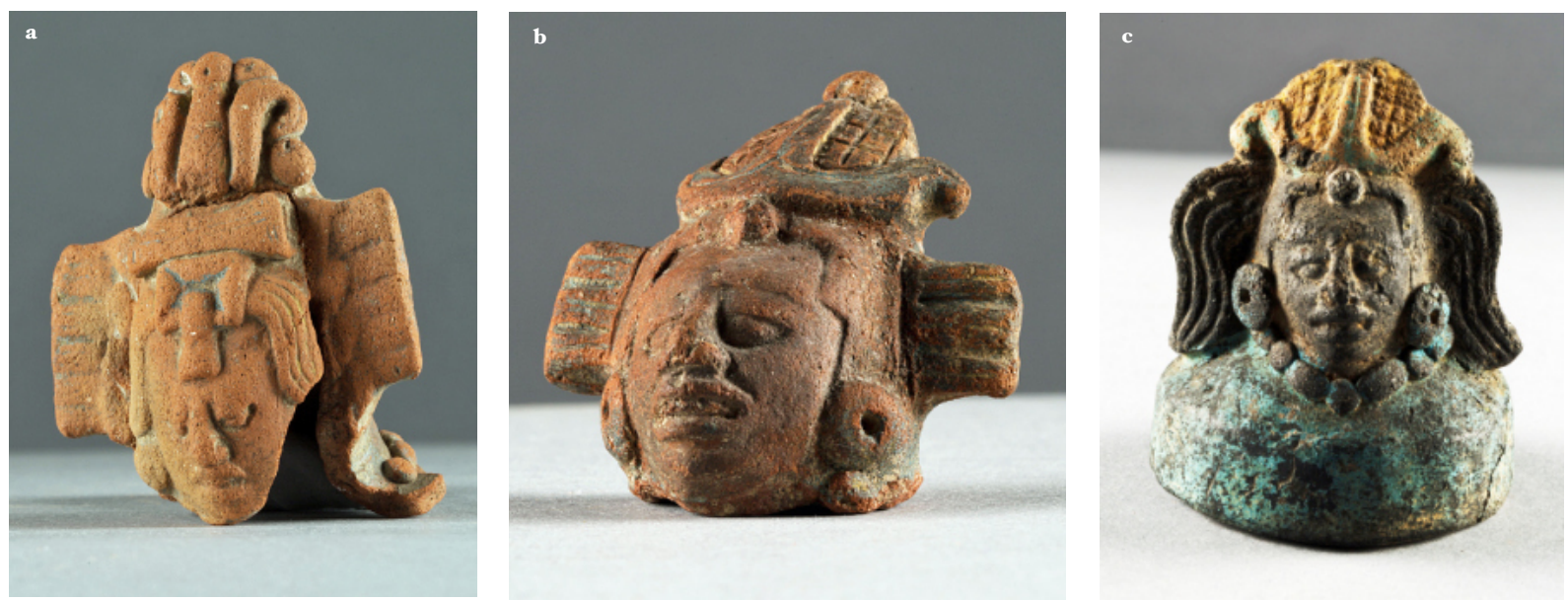

Figure 61. Representations of the Maize God.

(a-b) Broken heads from vessel lids GE I 00063 and GE I 00064; (c) Vessel's lid GE I 00042.

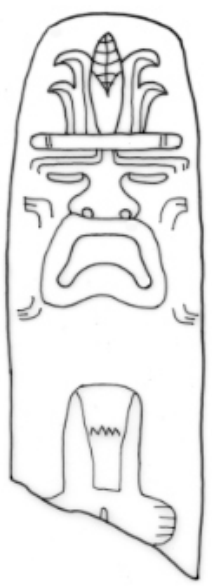

This maize-ear-motif derives from the earliest images of the maize plant. During the Middle Preclassic period, images from Olmec iconography show the plant in a naturalistic, schematized, or idealized manner. These representations are also linked to an anthropomorphic being that has been identified as an Olmec maize deity and, for the most part, were engraved on polished axes, preferably jadeite or serpentine stone axes (Figure 62). The images display maize plants sprouting from the cleft in the head of a monster-like personage that probably represents the earth or the mountain cleft from which maize originates (Pérez Suárez 2013:40; Miller and Taube I993:I08).

Figure 62. Incised jadeite celt with a representation of the "Earth Monster" with a sprouting maize plant from the head. El Sitio, Guatemala. Preclassic period. 

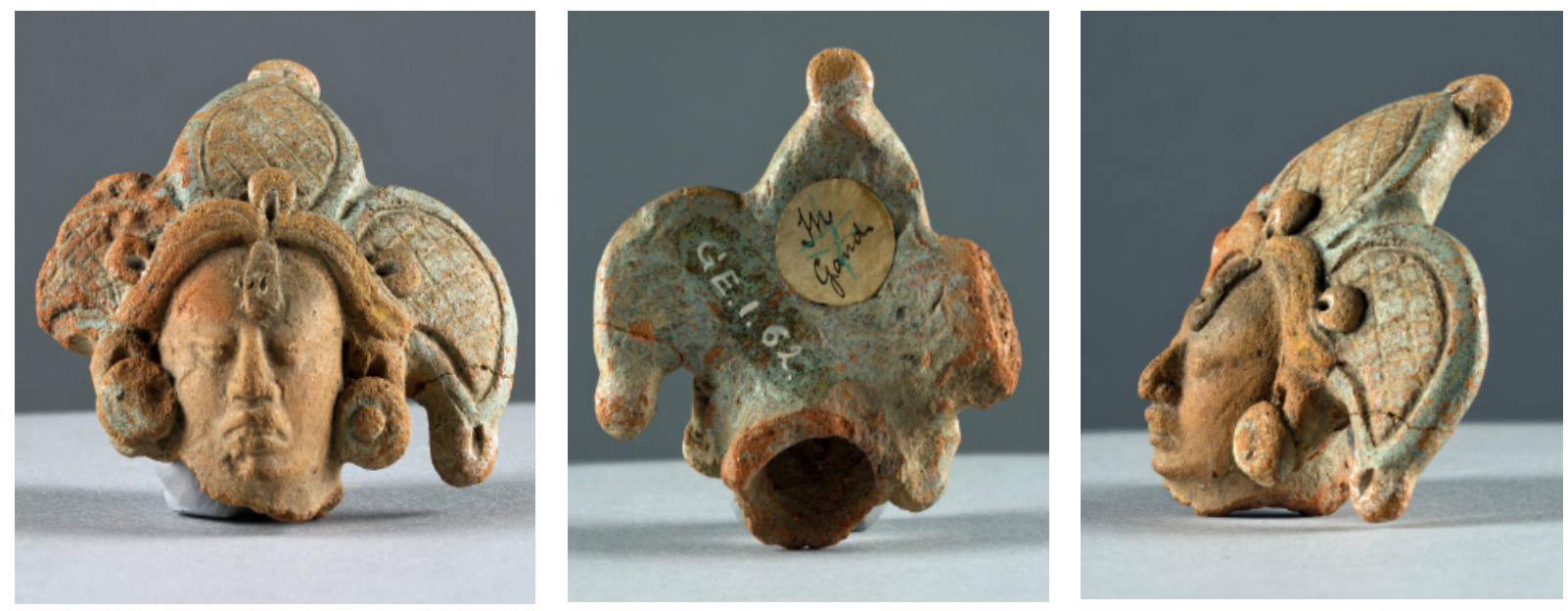

Figure 63. Broken head from a vessel lid GE I 00062, illustrating One Ixim, the Maize God, or his son One Ajaw (?), with a tri-pointed cap.

The head shown in figure 63 represents the Maize God as a handsome young man with an elongated head, wearing a jewel on his flattened forehead, large earflares and a tri-pointed-cap with hanging spheres at the points, possibly referring to jade or nacre beads.

In Classic Maya art, representations of One Ixim's son, One Ajaw, appear in which he is wearing a paper headband called sak buun that was made from the bark of the ficus tree ('amate' paper). The sak buun is frequently decorated with the head of a deity that Stuart (2013:I23-136;139-I4I) identified as the personification of buun "paper", (one of the so-called 'jester gods', identified as such by Linda Schele in 1976 , because of the resemblance to medieval court jesters). This deity appears with a stylized form of a flower that refers to the ficus flower (Figure 64).
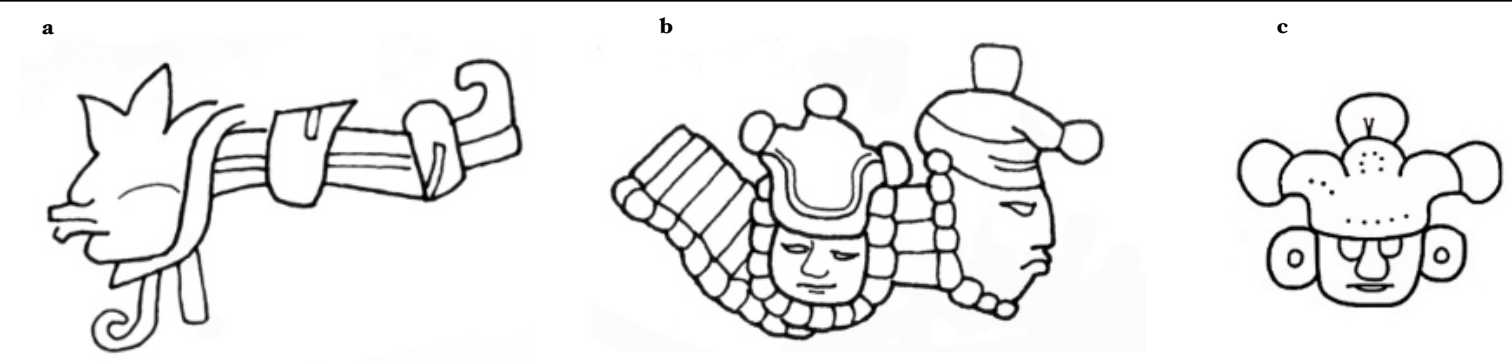

Figure $64(\mathrm{a}-\mathrm{c})$. The sak huun paper headband with a head (s) representing the huun deity.

One Ajaw was the grandson of the creator deity, Itzamnaaj, and he inherited the knowledge and wisdom of his father and his grandfather. Paper was used to record the knowledge of the creator deities, and the buun deity was both the personification of paper and the personification of their knowledge. The sak buun headband represents that knowledge. When the ruler became king, he donned the paper headband of One Ajaw and acquired that supreme knowledge (see figure 58c). (Bassie-Sweet personal communication, 2019). 


\section{ROYALTY ATTRIBUTES}

The polychrome lidded vessels shown in figures 36 and 37, page 57, could represent the royal person, ancestors, people of the nobility or deities, as emphasized by the hairstyles, the use of necklaces, ear ornaments and feathered headdresses. Three elements present in these vessels are of special interest: the mat-sign, or jal-glyph, the use of jadeite ornaments and feathers, and the use of blue color in the manufacture of the vessels.

\subsection{The mat or jal-sign}

During the Postclassic period, the Maya called their rulers ah pop, or "He of the Mat", and the term was synonymous with ajare, or lord, itself. The mat-sign represented the reed mats used by the nobility (Figure 65). The pohpol naab or "mat house" of the type referenced in Colonial dictionaries, was the community house for dance and performance, banquets, divination, or tribute payment, as well as a place where the community council met. The root pohp means mat, linking the community council and the mats on which its members would sit (Miller and Taube I993:IIO-III). However, Classic Period rulers did not sit on mat thrones, they sat on jaguar-pelt cushions (Basie-Sweet, personal communication, 2019).

Figure 65.

The mat or jal-sign.

(a) Textile technique

(twill 2/2);

(b) "Foliated Maize God"

in dancing pose.

Relief from Uaxactun.
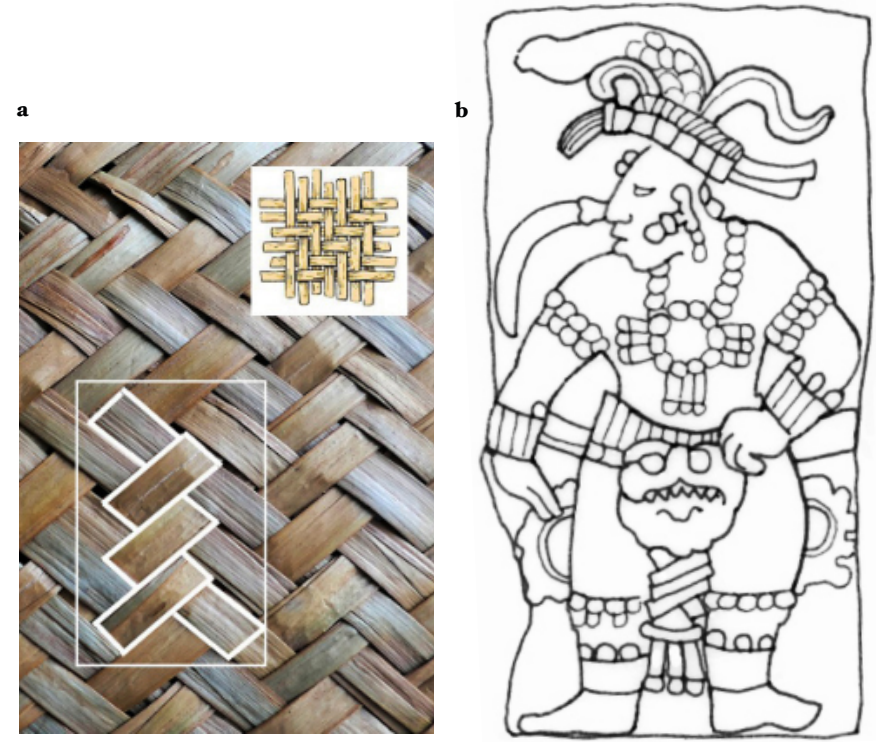

Although often referred to as the mat-sign ( $p o h p$ ), hieroglyphic inscriptions from the Classic period and associated art suggest that the jal-sign never had this pronunciation or restricted significance. The sign was far more general in application than has previously been suggested, apparently referring to all sorts of woven materials. Although woven, braided, or twisted textiles were one key referent, the glyph seems occasionally to refer to plaited hair or twists of rope in addition to reed mats, which was a key symbol of royalty. There is no doubt, however, that jal primarely referred to woven cloth or mats (Stone and Zender 20II:8I). The glyph's graphic representation is derived from the textile technique, twill (2/2), used in their manufacture (Figure 65a). 
The jal-sign is omnipresent in art images from the Classic period, especially on garments, belts and headdresses worn by rulers during ceremonies. An example is the belt used by the Maize God (Figure 65b), made of two twisted fabric strips. The sign is also a metaphorical reference for the descent line, where kings are like strands replacing each other over and over (Bassie-Sweet, personal communication, 2019).

\section{The "belt head assemblage"}

The jal-sign appears in the so-called "belt head assemblage" which is frequently attached to the belt of a ruler. In its fullest form, the assemblage is composed of an ancestor image set upon a jal-sign with three axes or celts ( $\mathrm{T}_{24}$ ) hanging from it (Figure 66).

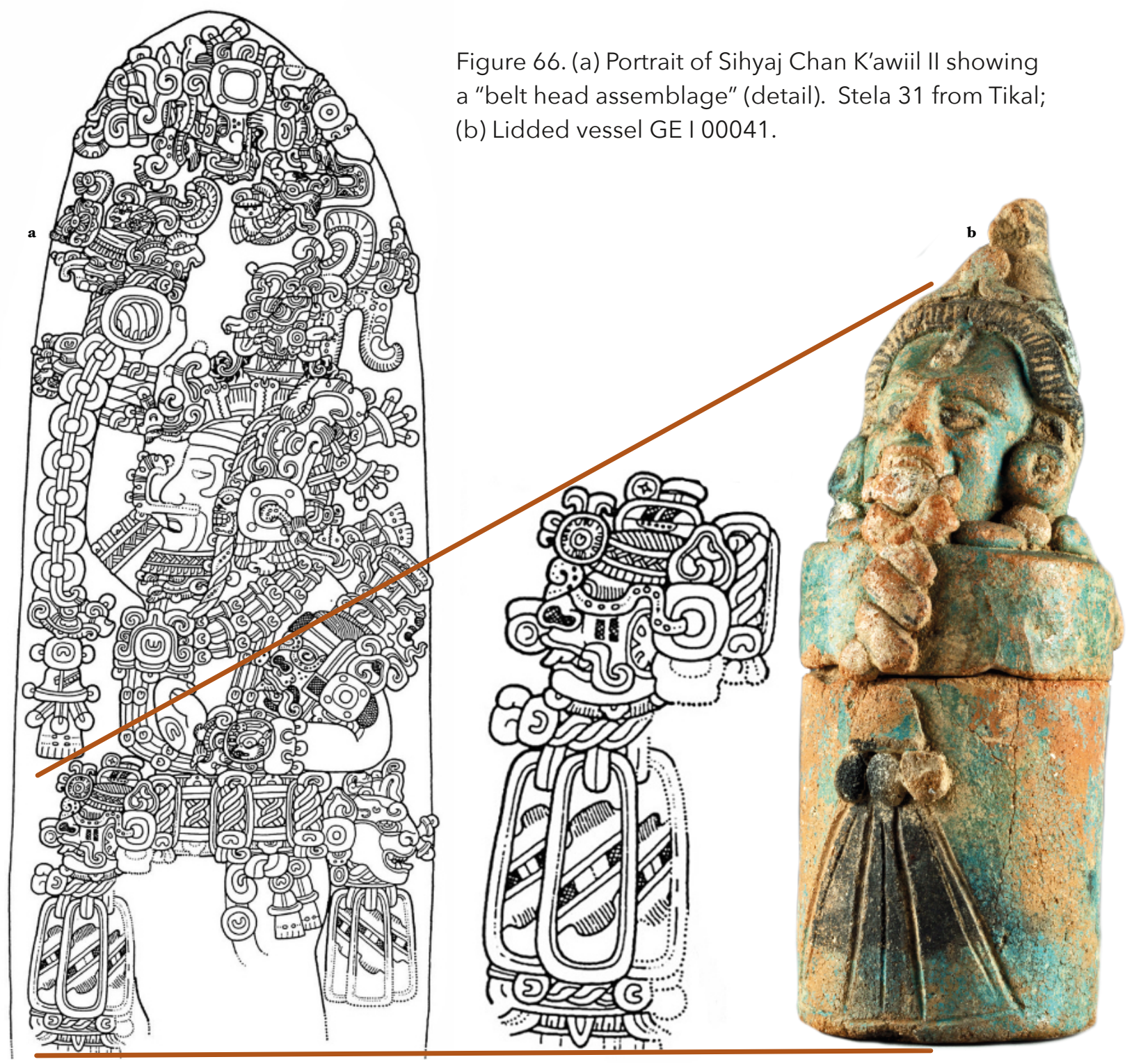


The ancestor can be represented by a portrait glyph or glyphs representing his/her name, or by his/her effigy. In this example from Tikal Stela 3I, the head spells out the name of the ruler, Sihyaj Chan K'awiil II's mother, queen Lady Une' B'alam (a). The belts from which ancestral effigy assemblages hang are frequently composed of sky signs. Given this context, Stuart (2010:29I-293; fig.I2.5) suggested that the axes (T24-sign) on ancestral effigy assemblages "may have been likened in some way to lightning flashes descending from the heavens." In other words, these effigy axes represent thunderbolts. Bassie-Sweet, suggests that the axes may specifically represent the primary triad of thunderbolt gods (personal communication 20I9). Vessel GE I 0004I(b), in its entirety, illustrates this assemblage.

\subsection{Jade ornaments}

Jade is the general term used for jadeite. It was an elite commodity, a royalty attribute, and an important commercial item. Jadeite was considered among the most precious of materials and was fashioned by Maya lapidary artists into a wide range of sacred and valuable objects. Artifacts made of greenstone are usually discovered in places linked with cults or ritual activity, such as burials, caches, or underground water storage chambers, known as chultuns (Rusek 2OI4:I39-I40)

The exploitation and application of jade by the Maya reached its apogee in the Classic period when the social hierarchy had already fully developed. Only in the Classic Maya culture did the mineral recover the value and respect it had enjoyed among the Olmecs. The only noticeable difference between these two cultures was the kind of raw material used: if the Olmecs relished bluish jade, then the Maya (most likely due to changing aesthetic preferences and fashion) preferred jade of an emerald green color (Sharer and Traxler 2006; Coe 2005, cited in Rusek 2014). The tradition of making ornaments from this material gradually disappeared in the Postclassic period, to sink into oblivion shortly after the Spanish invasion. Jade played the role of one of the most prominent symbols and markers of social status, its rarity also contributing to its value. Even small lumps were providently polished and exploited in a manner to make the best use of every possible fragment. Jade, as has already been emphasized, was first and foremost a symbol of power, as only certain people could afford to wear jewelry made of this material (Rusek 20I4:I39-I40).

The Maya appreciated jadeite for its beauty and color, for its value as a precious substance, and, above all, for its symbolic nature. The green-blue color was associated with maize, water, the sky, vegetation, and life. It also refers to the centrality of the cosmos and was considered as the personification of sacred breath. For these reasons, it was used in funerary practices. Masks, body ornaments such as large necklaces, pendants, bracelets, anklets, and dress elements made of jade beads, as well as small jadeite amulets deposited in the mouth and other vital points of the deceased symbolized the renewal of life. In addition, when rulers showed themselves with an impressive outfit in which 
jadeite beads were integrated, they personified the centrality of the cosmos in the image of the Maize God, and legitimized symbolically and ideologically their ancestry and their authority (Taube 2005:47; Stone and Zender 20II:7).

The necklace with an effigy pendant from the Chich'en collection, as well as the other beads (Figure ${ }_{77}$ ), are made with the preferred variety of jadeite among the Maya, now called "imperial jadeite" (Chloe Andrieu, personal communication, 2019).
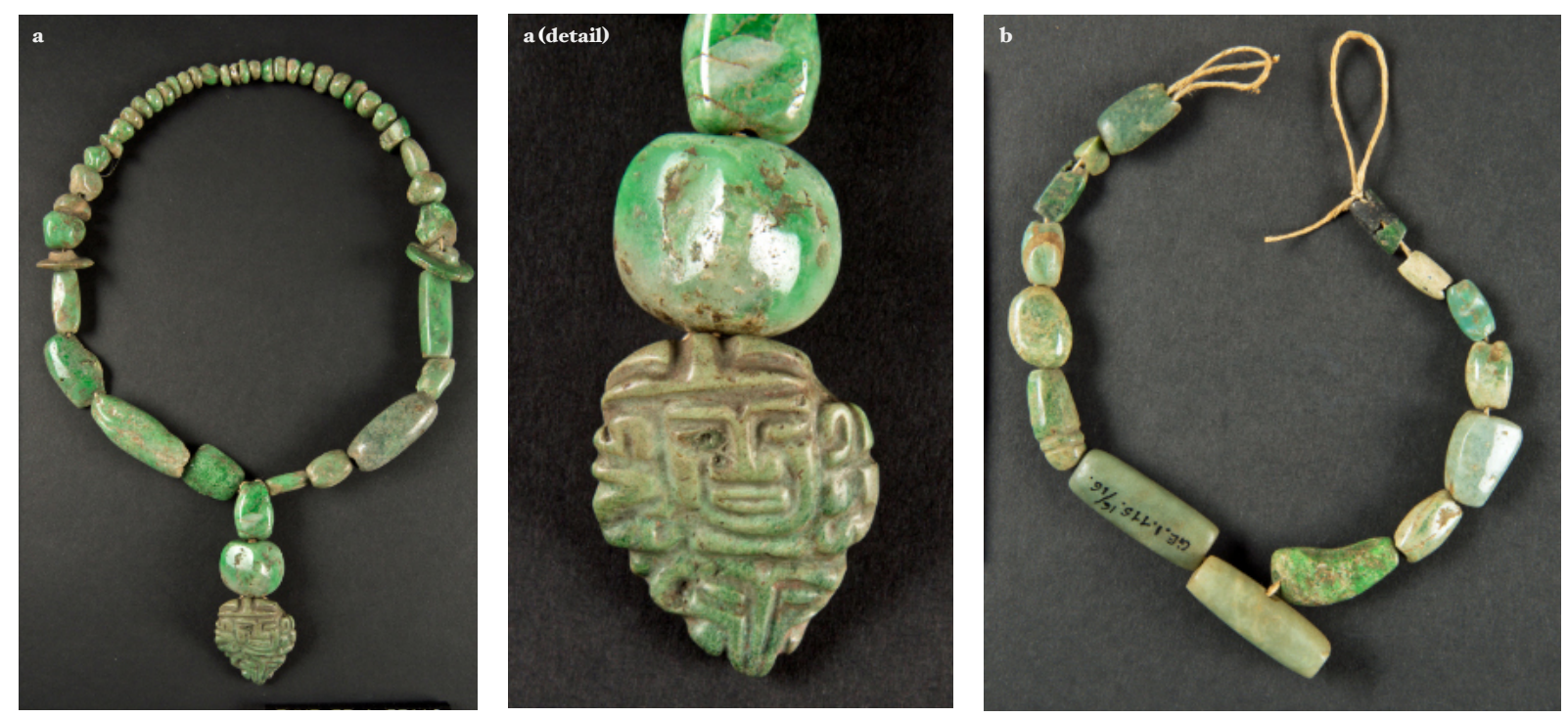

Figure 67. Jadeite objects. (a) GE I 00114; (b) GE I 00115.

Similar pendants or amulets from Zacualpa, Quiché (Figure 68), are described by S. Lothrop (1936:53-60). Another example is a jadeite pendant recovered from Tikal Burial I96, described by Hellmuth (1967:I87, fig. 95). These effigy pendants could possibly be representations of the maize deity.

Figure 68. Jadeite amulets from Zacualpa, El Quiché.

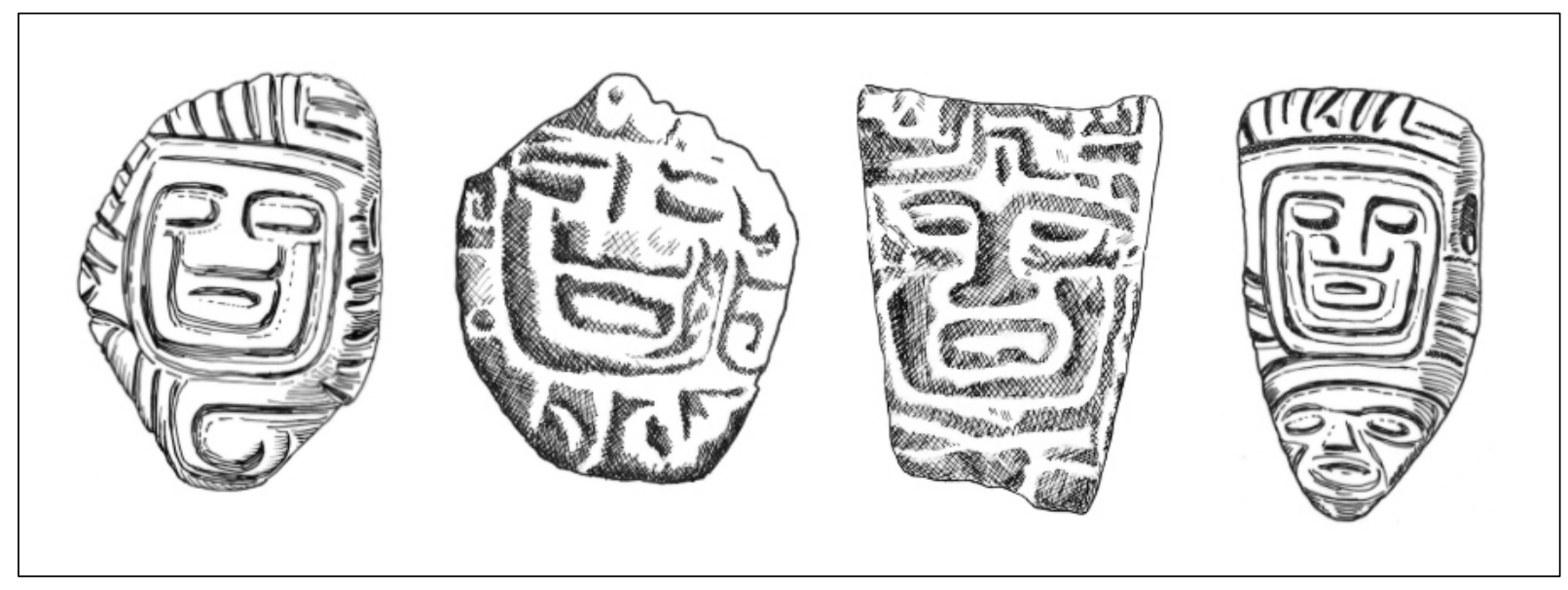




\subsection{Feathers}

The ancient Maya trapped and bred birds for feathers, which they used to make headdresses, crests, shields, and to decorate canopies, fans, spears, scepters, and other personal ornaments. Feathers were also used to decorate cotton garments exclusive to the nobility, integrating them into the fabric during the weaving process. Feather work was highly developed in pre-Columbian America. Early Spanish writers relate the importance of this craft among Highland Maya, who had aviaries where birds were bred for their plumage. The most highly prized feathers were the brilliant iridescent-green tail plumes of the quetzal, reserved for royal use.

Most of our knowledge of ancient Maya feather work comes from its depiction in other media, such as polychrome pottery, murals, sculpture, and monuments. Royal portraits show how elaborate and highly developed this craft must have been. The lavish use of quetzal feathers and the best examples of the panache of headdresses worn by the Maya rulers are well documented in the San Bartolo Murals in Petén, Guatemala, and the Bonampak murals, in Chiapas, Mexico. Such long plumes must have been the tail feathers of the quetzal, which reach up to a meter in length (Sharer and Traxler 2006:4I). The procurement and display of vibrant feathers allowed Maya lords to signal status, rank, and identity. Only those with ajaw, or "lordly", status used an abundance of feathers, others being restricted to a single plume or two in a feather panache (Houston et al. 2009:44-45). A few examples of feather-works from Central Mexico, dating from the $16^{\text {th }}$ century, have been preserved. ${ }^{64}$

The lid of a polychrome vessel from Chich'en illustrates a lord wearing a feather headdress, a large necklace and ornaments presumably made of jadeite. This piece shows traces of blue paint (Figure 69b).

Figure 69. (a) Feather headdress known as "Penacho de Moctezuma." Weltmuseum Wien. (b) Vessel lid GE I 00043
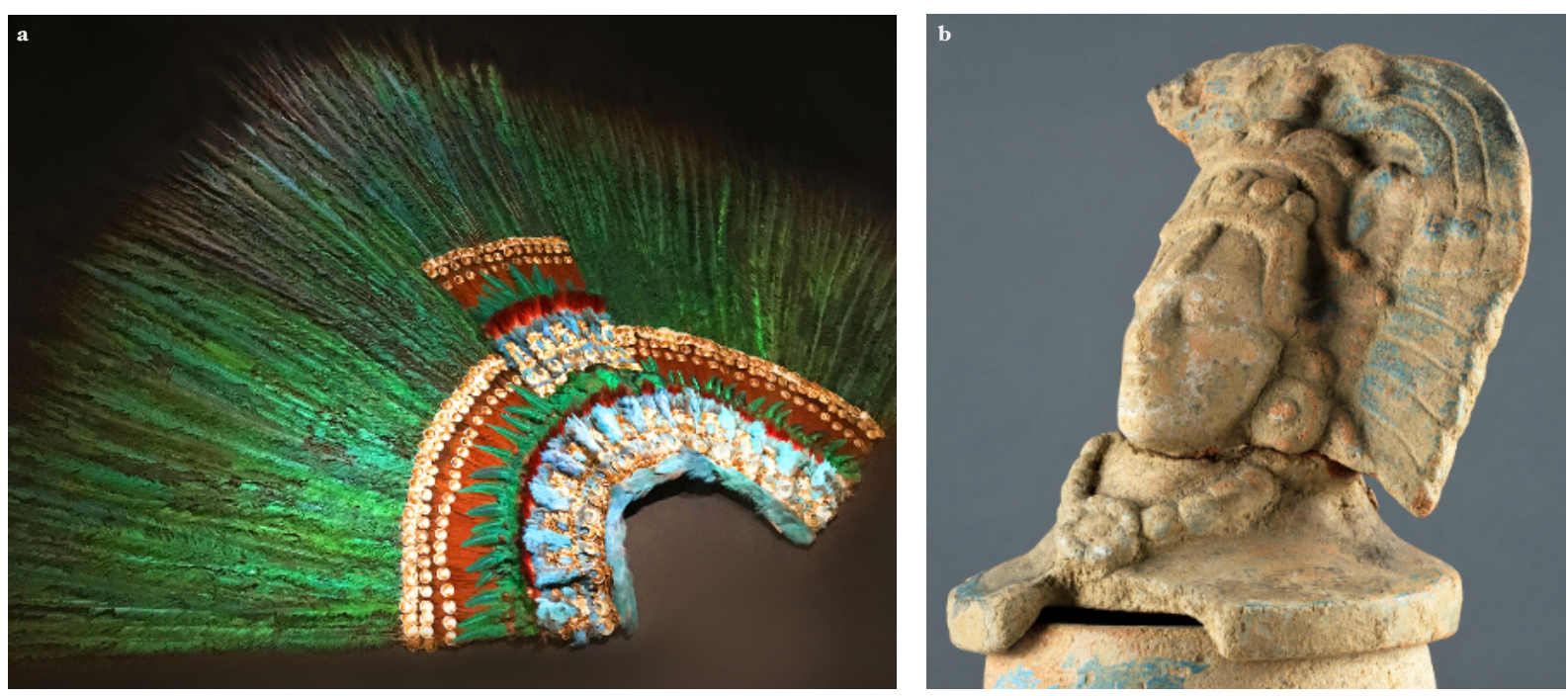


\section{4. "Maya blue"}

The polychrome lidded vessels from Chich'en are painted with a brilliant blue-green pigment. It is known as "Maya blue", since the Maya were the first to develop this color, whose use spread throughout Mesoamerica. Unlike the colored clays and minerals most used as pigments, Maya blue is an ingenious combination of inorganic and organic matter: a white clay (palygorskite) dyed with indigo (Indigofera suffruticosa). It is likely that Maya blue developed out of contacts with weavers, who were familiar with dye plants and techniques for dyeing or printing cotton cloth. This brilliant and stable blue pigment came to dominate the Maya color systems by the end of the fifth century AD, attaining a centrality that was maintained for nearly a millennium. Maya blue was used until Colonial times, for example, in the manufacture of manuscripts by the Spaniards. (Houston et al. 2009:78).

The scientific analysis of the materials and dyes used in the manufacture of the Florentine Codex, revealed that the colors turquoise blue and brilliant green, called quiltic, used to illustrate the quetzal feathers, contain palygorskite clay and the organic dye indigo blue. ${ }^{65}$ In the $16^{\text {th }}$ century, dyes had to be imported from the southern Maya region to Mexico City. Maya blue, texotli in Nahuatl, was highly appreciated for its distant origin, as well as for its composition. This pigment, made with a mineral that comes from the interior of the earth and an organic dye that comes from a plant that grows with the energy of the sun, gathers both substances of the cosmos: from the sun and from the earth. Maya blue is used extensively in the Florentine Codex to represent everything that is precious. For example, the backgrounds that represent the sky in all the images of the sun, the moon and the stars; the capes, diadems and royal jewels of the Tlatoanis of Mexico-Tenochtitlan and other cities; the distant mountains of the landscape of New Spain, using aerial perspective, as well as the crystalline waters in which supernatural fish are seen. They were painted with this precious color. The contrasts obtained through the use of color luminosity and hue, to produce figures that have different symbolic status, is relevant (Magaloni Kerpel 2020:60-63).

The use of this blue lake appears in a wide variety of contexts, including sculpture, murals, textiles, body paint, and architecture. Maya blue is one of the most stable indigenous paints. It is unaffected by acids, alkalis, solvents, oxidants, reduction agents, biocorrosion, or moderate heat. It remains sensitive, however, to extreme high temperatures and blackens upon firing in a kiln. For this reason, Maya blue appears only as a postfire paint on ceramics. Palygorskite deposits have been uncovered in Izabal Lake in Guatemala and in the Yucatán Peninsula (Houston et al. 2009:65-66, 78).

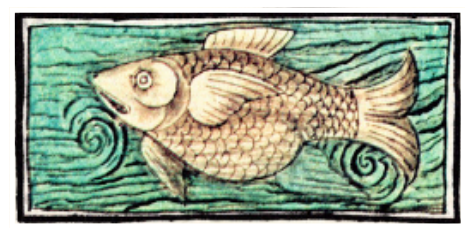

Florentine Codex, Book XI, page 214, folio 62. 


\section{SYMBOLISM OF THE BALLCOURT}

The square jadeite tablet (Figure 70) has two perforations on both sides allowing it to be fixed to belts, necklaces, or headdresses. Georges Léger did not mention the exact place where he recovered this piece. It is possible that this finely polished tablet was found together with the jadeite beads of the 'necklace' found by Léger in the sarcophagus. However, the tablet shows a horizontal I-shaped diagram with a circle in the center, similar to the images of Postclassic closed-type ballcourts illustrated in Colonial Mexican codices, such as the Codex Magliabechiano. ${ }^{66}$ Therefore, it is possible that this tablet was manufactured in the Postclassic period and was left, as an offering, at the funerary structure after the burial, presumably, in the chamber on the north wall of Structure 2, together with other stone offerings. Considering the high value of jadeite as a precious matter, its deep symbolism and its use in funeral practices, a logical conclusion could be that this tablet belonged to the grave goods of the deceased, but this remains hypothetical.

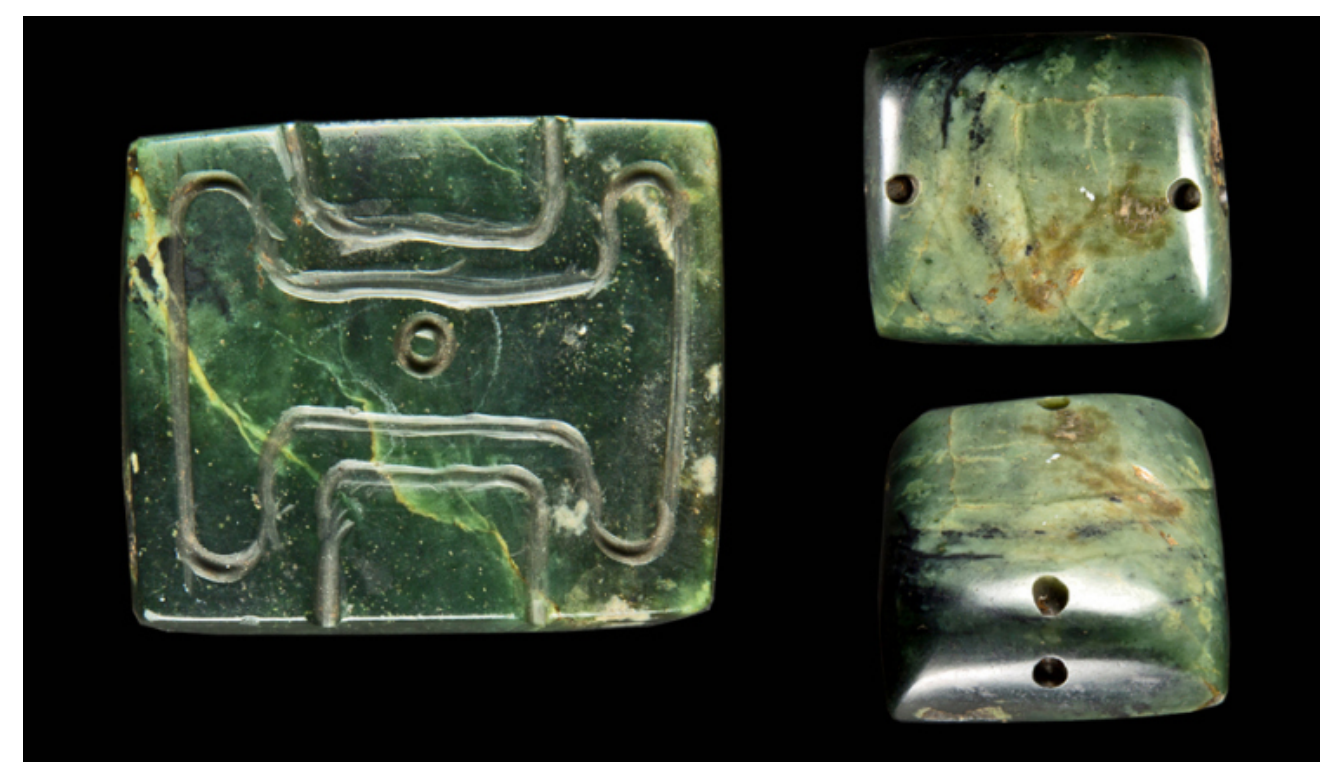

Figure 70. Square jadeite plate GE I 00116.

The diagram on this plate is a reference to the ballgame and its religious symbolism and could also point to the adjacent west ballcourt of Plaza A of Chich'en. In some Classic cities, such as Ceibal, Copán, Chichen Itza, Dos Pilas, Tikal and possibly Piedras Negras, the Maya configured two architectural structures in unison: the ballcourt and a tomb associated with the founder of their lineages, whose grave was located inside or under a pyramid (Houston 20I4; Velásquez 2015:263). At Chich'en we observe a similar configuration (Figure 7I).

The relationship between the ballcourt and a burial has been represented in Maya art by means of very simplified graphemes, which do not fully express the rich symbolism that we know from the mythical events narrated in the Popol Vuh, and from the images of the ballgame, which generally relate to death, sacrifice, rebirth or regeneration (Figure 72). 


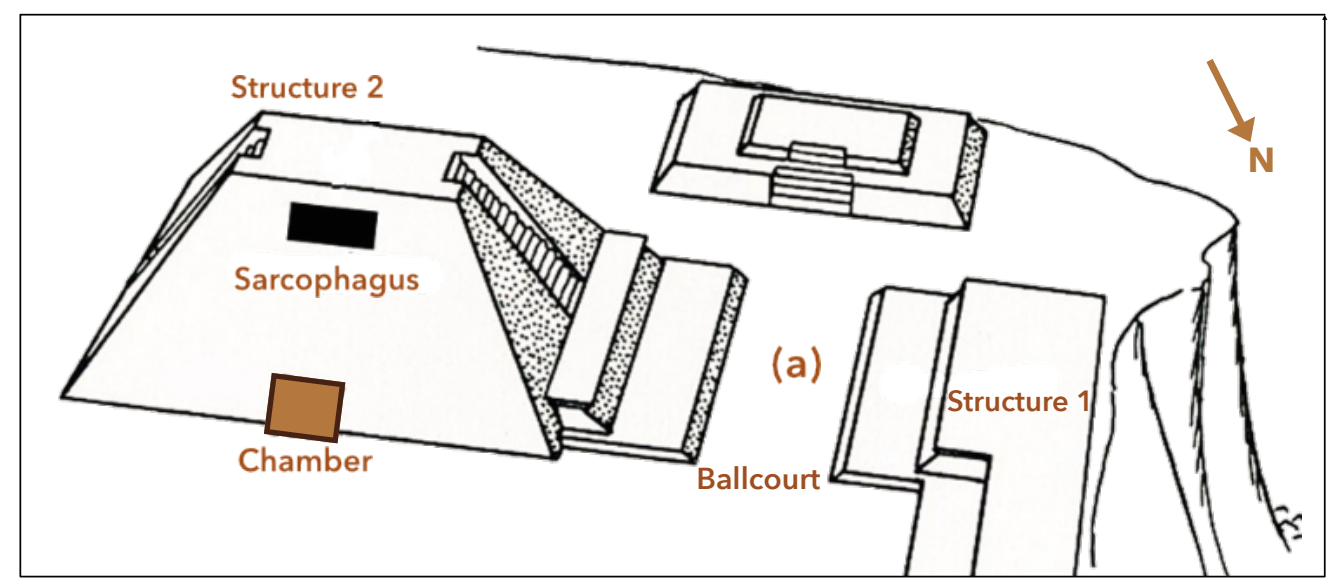

Figure 71. Pyramid/ballcourt complex, Plaza A, Chich'en (detail).

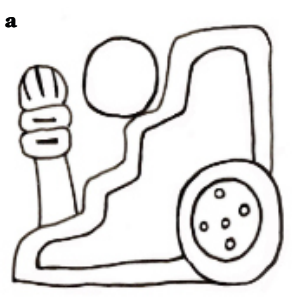

b

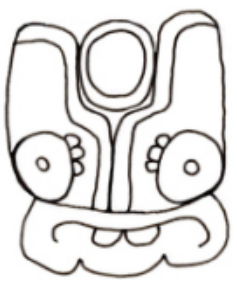

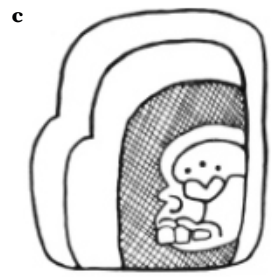

Figure 72 (a-b) Graphemes related to the ballcourt; (c) Muhk-sign related to burials.

Grapheme (a) represents the stepped profile of the ballcourt, and grapheme (b) illustrates the ballcourt as a cleft in a mountain or canyon with a ball inside, a direct reference to Yax Hal Witz, "First True Mountain", place of rebirth of the Maize God after having been beheaded in the $I k^{\prime}$ Waynal, or "Place of the Black Underground Abyss". The allusion to I $k^{\prime}$ Waynal could be causally related to the canyons and gorges of the natural landscape (Velásquez 2015:262; fig.I8).

Grapheme (c) mubk, is the Mayan word for "tomb" and "burial". This sign maintains the basic shape of the grapheme for "stepped ballcourt", but includes a skull buried in a vault under a staircase. The dark background is indicated by cross-hatching. The mubk-sign is rich in symbolism and bears a semantic relationship with the hieroglyphs for "staircase", "cave", and "death." Like caves, staircases were secluded locales, reminiscent of death and transformation (Stone and Zender 20II:I09).

In addition to conveying mortuary symbolism, skulls were natural symbols of sacrifice by decapitation. Ritual decapitations reenacted the mythological narrative of the Popol Vuh, in which the Hero Twins played ball with the Death Lords in the underworld in order to recover and restore the decapitated body of their father, the Maize God (Stone and Zender 20II:65).

According to Gutierrez (1993:-1-3), the Maya considered the ballgame as a reconstruction of cosmic Creation, and the ballcourt as the place of Creation, the place of the first maize and the first humans. The author proposed that, in some 
ancient Maya cities, ballcourts were aligned towards mountains with a cleft at the top, mountain ranges with deep gorges or towards artificial mountains. BassieSweet (2008:229) noted that ballcourts were a replica of a canyon or slit.

According to Van Akkeren (personal communication, 20I8), the ballcourt is also a metaphor for the cornfield's furrow.

In Chich'en, the ballcourt-pyramid complex is aligned with the Mestela canyon to the south (see figures IO, II and I3). The merging of the burial pyramid and the ballcourt reaffirms the concept of the revival of life in the center of the cosmos (Figures 73 and 74 ).

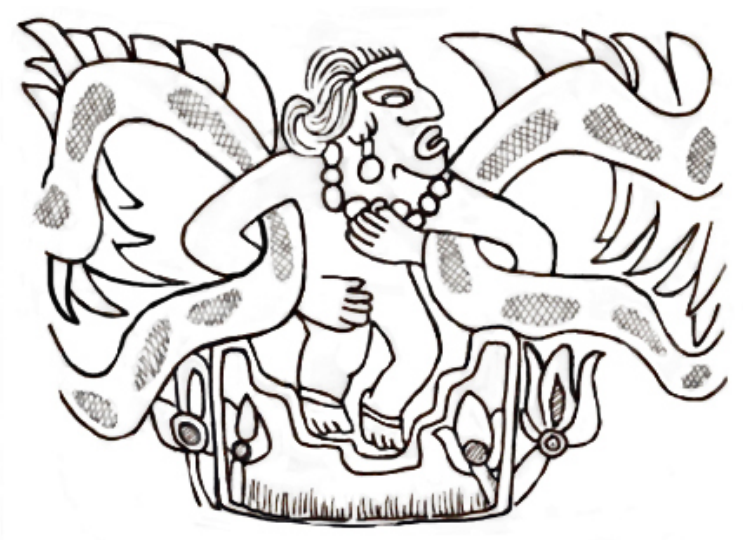

Figure 73. Maize God's birth from ballcourt (Vessel K5226, detail).

Figure 74. The Maize God emerges from the Yax Hal Witz or "First True Mountain".

(a) Ballcourt complex, Plaza A, Chich'en (detail) and cross section view;

(b) Bonampak, stela 1.
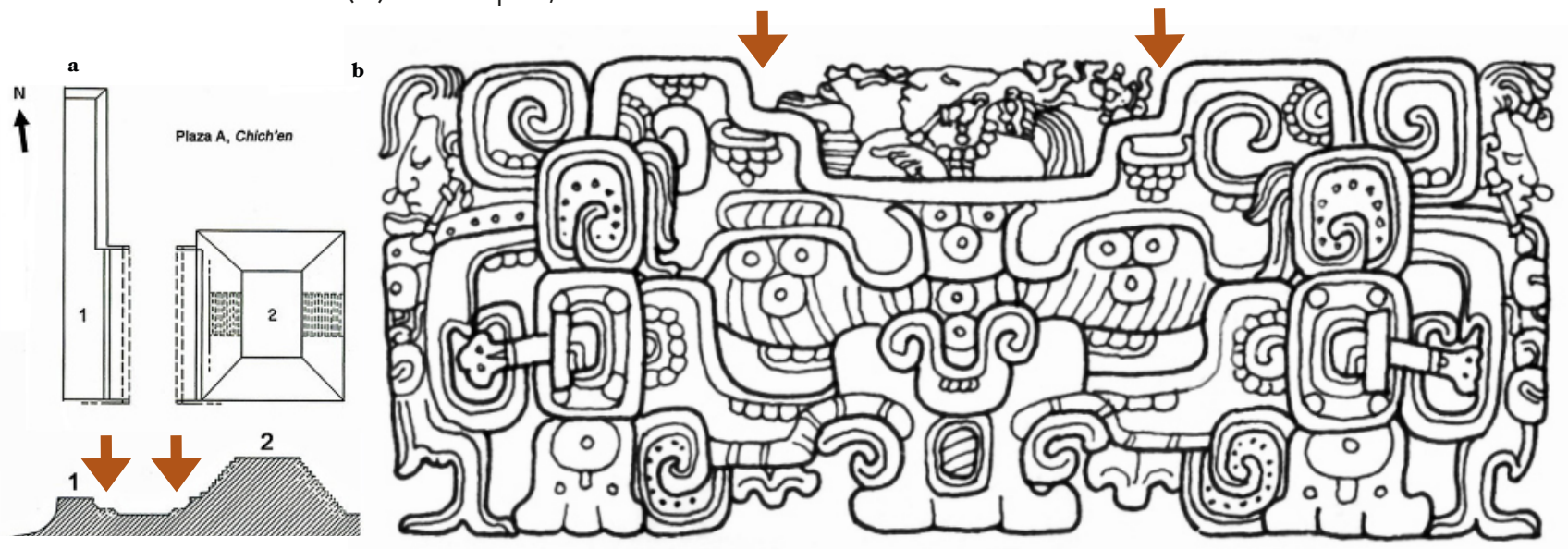


\section{PRELIMINARY \\ CONCLUSIONS}

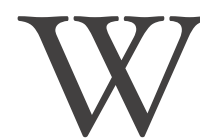

hen Georges Léger excavated two tumuli in Finca Chichen, in 1894, he already realized the significance of his findings. Contacts with the British explorer Sir Alfred Percival Maudslay, confirmed the exceptional character of the site and his findings. ${ }^{67}$ Consequently, he took steps to protect the artifacts. In his letter to the University of Ghent (I895), he made it clear that he offered the collection to the university of his hometown, being convinced that it would deal with the collection in a careful manner. At the time of his excavation, the knowledge of Maya history was still in an embryonic phase, and Maya artifacts were considered exotic objects with a high monetary value. It is, therefore, remarkable that Léger decided to keep the objects together. As a result, we have access to archaeological artifacts whose origin is well established and whose meaning can be interpreted using the results of more than Ioo years of research. The objects have a meaning in themselves but, being part of a complex setting in which individual pieces contribute to sketching a holistic template, makes them exceptionally interesting.

Chich'en was populated from the Late Preclassic period (Ioo BC) but reached its maximum development at the end of the Classic period (70o AD). The site continued to be occupied throughout the Postclassic period until the early colonial period in the mid- $-6^{\text {th }}$ century, when the Dominican friars established the first towns under Spanish rule (1540) and resettled the indigenous population of Verapaz. The artifacts from Chich'en show characteristics and iconography that places them in different spaces and time periods, which suggests that the site's strategic location within the ancient trade and pilgrimage routes was the determining factor during the long occupation of the site. Chich'en was a major center, continuously visited for ritual purposes.

The Maya collection of the Ghent University Museum, GUM, represents the funerary context of a person with ajaw or lordly status, possibly the founder of a lineage established in Chich'en. The multiple offerings of fine, decorated pottery, some containing human relics and obsidian blades, as well as the flint, rock crystal and other stone objects deposited in the funerary mound, confirm that Chich'en was a center of ancestor worship, with a privileged place within a sacred geographical setting. Likewise, the architectural complex resulting from the unification of the funerary pyramid and the west ballcourt, as well as the alignment of these structures towards sacred features of the landscape - Chich'en Mountain, the Mestelá river canyon and cave - gave the site a great symbolic value associated with death, rebirth and agricultural fertility. The iconography of many artifacts is related to main deities, like God K'awiil, God Itzamnaaj, the Maize God, and the Jaguar God of the Underworld. Furthermore, the presence of 
royalty attributes, such as jadeite ornaments, the use of Maya blue paint, and the mat-signs on pottery found in and around the sarcophagus, support this interpretation.

There, nevertheless, remain many open questions, one of which concerns the quality of the pottery. Certainly, the luxury appearance of these artifacts, their polychromic and iconographic aspects, as well as the hieroglyphic inscriptions, reveal that the makers were using the techniques and the knowhow of the Classic period, even when they didn't reach the level of excellence of the artisans from the large centers of the Lowlands. The polychrome lidded pots, for example, had a purpose and a deep symbolic meaning, and their manufacture was most likely intended for the burial mound. The presence of the artifacts in Chich'en was probably not the result of accidental trading with the Lowlands but could indicate the existence of a long ceramic tradition in the Chich'en area. In I949, A. L. Smith (I955:62) reported that Chich'en was still a ceramic producing center.

A thorough study of the artifacts by experts from different disciplines will be necessary to identify materials and techniques used in the manufacture of the artifacts, hopefully enabling us to trace their place of origin and the way they travelled before ending up in the site of Chich'en. Such analysis, as well as the study of the iconography, could help to refine the long timeline of Chich'en and its place in the wider Maya history. A scientific excavation and, if possible, a reconnaissance of the Mestela cave, could confirm the results. In addition, the study of the artifacts recovered by A. Ledyard Smith and Charlotte Arnauld during their archaeological surveys, now kept at the Museo Nacional de Arqueología y Etnología (MUNAE), will give us the opportunity to reunite, if only virtually, the materials found at Chich'en.

An extended study of artifacts from Verapaz in the collections at the MUNAE, the Los Angeles County Museum of Art (LACMA), the Popol Vuh Museum, the Fundación La Ruta Maya, and the Fundación Nacional para las Bellas Artes y la Cultura, in Guatemala, see Annex 4, could also shed light on the history of Verapaz and the relationships with their neighbors from the Highlands and the Lowlands of the Maya area. Most important, as mentioned by Charlotte Arnauld in her final comment to this report, a multidisciplinary study could also cover the archaeological findings at Raxrujá, Cancuén, Salinas de los Nueve Cerros, Quiriguá, and other places in the proximate Lowlands. Certainly, the recently discovered artifacts at El Aragón site in the city of Cobán, close to Chich'en, will represent a major contribution to a better understanding of the role of these sites in this transitional zone between the northern Highlands and the Lowlands of Guatemala.

Despite the damage to the site, the structures and the monuments, the place is still considered sacred among the Q'eqchi'. Perhaps this is the reason for its survival. 


\section{(0) FINAL COMMENT}

$\mathrm{T}_{0}$

o conclude I would like to give the opportunity for a final comment to Charlotte Arnauld, who graciously offered us valuable remarks and suggestions. Her letter sent on February 23, 2020 is copied below:

\section{THE IMPORTANCE OF THE CHICHEN SITE,}

s indicated by Julia Montoya in her report, Chichen is a site strategically A located on trade routes linking the Maya Lowlands to the Maya - Highlands. But even more relevantly, it is located in a central valley in the (Maya) Q'eqchi' territory which extends on the transitional region between both areas, close to the frontier with the Poqomchi' territory to the south (Tactic Valley, north slopes). Chichen was the Postclassic capital of the Q'eqchi', close to Xucaneb Mountain, the all-important Tzuul Taq'a of the Q'eqchi' people.

The Dominicans, who entered the Tezulutlán (or "Land of War") by the year 1542 or 1544 in name of Bartolomé de Las Casas, soon succeeded in "reducing" the Indians in several new villages, which were all in the Q'eqchi' territory - particularly Cobán, their capital (for whatever reason, this remains unclear). This was done in only one year, if we are to believe their reports ( $1544^{-}$ 1545). This means that they had established good relations with a Q'eqchi' cacique, not a Poqomchi' one (the Poqomchi' reductions of Santa Cruz Menchú and San Cristóbal Cagcoh were formed much later). This cacique was probably Juan Matac B'atz of Ajpo B'atz of Chamelco, or someone in his line or house. The main "barrio" of Cobán (Santo Domingo) was settled by people "from Chichen and Xucaneb" (Escobar I84I, see my publication p. I28). I don't think Xucaneb refers to Chicán, which was a Poqomchi' fortress in the Valley of Tactic, but this postulate remains to be proved. The settlement of "Xucaneb" was certainly Q'eqchi' and may have been dispersed all over the Chichen Valley and the Xucaneb slopes on the Q'eqchi' side.

Matac B'atz soon became a gobernador, entirely acknowledged by the Spanish authorities (including the Madrid authorities which Matac B'atz visited in $155^{2}$, in the absence of Charles the Fifth who had already resigned). This reconnaissance did not last long, but at least during some moment he embodied the perspective of a Maya-Spanish governance contract quite different from what was to be finally implemented a few years later. This cannot be underestimated. 
I don't know of any other circumstance in the Guatemalan (Maya) Highlands in which we can explore such a remarkable coincidence of: a preHispanic capital (Chichen) linked to a religious place (Xucaneb), an historically important Maya leader, Matac B'atz, and an entirely new settlement system headed by the city of Cobán, in which the main barrio was dedicated to this same cacique's people.

It is a paradox that the site of Chichen is morphologically a Classic site; however, it was still occupied during the Postclassic, as seen by Smith and me. This means that the politico-religious importance of Postclassic Chichen was at least partly based on the Classic place of Chichen. This is not entirely exceptional in the Highlands (see Zaculeu, or Zacualpa, and other places). What is interesting is that we have more evidence of Classic-to-Terminal Classic relationships between Chichen and the Lowlands than in other Highland places also located close to the Lowlands. It may be that this particular situation was repeated along the transitional zone between both areas (as in the Ixil region), but the case of Chichen could be better documented archaeologically and ethno-historically, due to the recent research done at Raxrujá, Cancuén, Salinas de los Nueve Cerros and other places in the most proximate Lowlands.

The heritage of a Classic Lowland-related culture at Chichen to support the much later claim of sovereignty (in Postclassic and Colonial times) is something which deserves scrutiny. This would, perhaps, change the vision we have of the Highland Maya and their reaction to the Spanish entrada. But primarily this would help clarifying the transmission modes of this Classic Lowland culture into the Postclassic Highlands through places other than the trade port of Kawinal in the Chixoy Valley - a recent foundation compared to Old Chichen. We do not know who - in relation with the Lowlands - was living and governing in Terminal Classic-Early Postclassic times. We do not know what those Chichen people did take from the Lowland civilization, and what they maintained and transformed within Chichen and surrounding places. This would be a fascinating case of cultural transmission through a long crisis, which saw the collapse of political regimes and urban settlements in the southern Lowlands from 800 to $950 \mathrm{AD}$. Chichen seems to have survived those troubled times, being located far away from the epicenter of the events (although this is speculative, and may remain so), Chichen could have participated in some events, like the final destruction of Cancuén in $800 \mathrm{AD}$; Q'eqchi' materials have been found in Lowland places by Terminal Classic times). 
The other side of this fascinating issue is the elite material culture present at Chichen during, and at the end of the Classic period. This is where the Léger collection of Ghent University is of great pertinency. Although this is a spontaneous impression which would deserve illustration and pondering arguments, I am struck by the contrast between the perfectly Classic Lowland iconography of many pieces of the collection, the delicate execution and balanced aestheticism, and the rough, even sometimes rustic, elaboration of other pieces that are obviously to be considered part of the same elite culture so marked by the Classic Lowlands. At the least, my first feeling is that this contrast should be deeply investigated through an attention given to the molding technique contrasted with other techniques. In short, my feeling is that the Late-Terminal Classic Chichen people, whoever they were, did not have the art and craft competéncy of the Lowland Maya, but did have the molds.

This would be a remarkable case of transmission through specific techniques that we would be able to describe. Similar cases are now explored in Belizean sites (see Carmen Tsing, or Chris Helmke). This is why the Léger collection should be carefully curated and kept open to research, following the well justified efforts of Julia Montoya.

\section{Charlotte Arnauld}

Directrice de recherche émérite

CNRS, ArchAm UMR8o96

Université de Paris Panthéon-Sorbonne

Paris, February $23^{\text {rd }}, 2020$
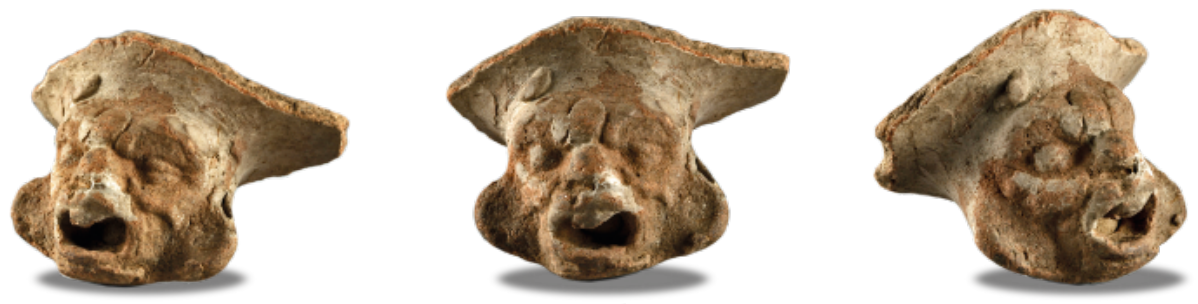

Anthropomorphic vessel foot (rattle-type), GE I 00069. 


\section{NOTES}

1. Gents Universiteitsmuseum (GUM), Ledeganckstraat 35, 9000 Ghent, Belgium. https://www.gum.gent/en/the-special-collections-of-the-gum-and-ghent-university

2. The new laws of the liberal government of Justo Rufino Barrios (1873 to 1885), allowed the coffee entrepreneurs to acquire large estates or "finca's." The land belonging to the indigenous people and to their communities came into their hands. The coffee producers imposed a neo-colonial regime and forced labor on the people living on their properties.

3. See on FAMSI website: www.famsi.org/reports-03029/03029Danienlmages.pdf. Images Q-1, Q-2, and Q-3).

4. Frans Olbrechts (1899-1958), was a renowned ethnologist-anthropologist and professor of ethnology at the University of Ghent. He was also director of the former Belgian Congo Museum in Tervuren, Brussels.

5. Stephan F. De Borhegyi, Hungarian archaeologist (1921-1969). Mr. Borhegyi was a member of the team of A. L. Smith during the Chich'en excavation in 1949. In the next two years he also organized the anthropology collection of the National Museum of Archeology and Ethnography of Guatemala (MUNAE).

6. The map shown in Fig. 19 was rendered by Kisa Noguchi Sasaki, based on the restoration sketch by Stephan De Borhegyi.

7. In the site maps from Smith (1955:fig. 39 and fig. 134), the river is mentioned as Río Chichen.

8. See Bassie-Sweet (1991) and Brady and Ashmore (1999) for an extensive review on caves in Mesoamerica.

9. The place-names associated with the location of the mythical ballcourt and the entrance to the underworld, Nim Xor and Carchah, as mentioned in the narrative of the Popol Vuh (also Popol Wuj), are likely a reference to San Pedro Carchá, located near Cobán. Some of these places still retain their ancient names today and may easily be identified in the Verapaz region (Recinos 1950:112-113; Tedlock 1996:255-256, 342, 355; Christenson 2003:120; Colop 2008:66; Van Akkeren 2012). This is an indication of the centrality of the Cobán plateau 's landscape in Maya cosmogony (Bassie-Sweet 2019:193; Van Akkeren 2012).

10. In Dos Pilas, for example, the pyramid called El Duende was built above the cave, also named El Duende, where the river flows. At the beginning of the rainy season, the water flows from the cave with such force and rumble that it is heard from afar. This seasonal phenomenon was intentionally used as a political strategy, which reaffirmed the sovereign's control over the elements of nature (Brady and Ashmore 1999:124-145). 
11. The legend "The Hills and the Corn", transcribed by Burkitt (1920:196), mentions 6 of the 13 sacred mountains of Verapaz that belong to the Xucaneb massif. Xucaneb Mountain plays the main role in the plot. Chichen Mountain is mentioned as Tsuul Txitxén, or Tzuultaq'a Chichen. Aj Akix més or Thorn Broom, is the name of another hill who also plays a role in the legend. Més is a tough weed used to make brooms (Burkitt 1920:200). The Proto-Mayan term for sweeping is mes and the mes-te in Mestelá refers to the més shrub (Bassie-Sweet, personal communication, 2018).

12. See also Arnauld (1986:40-41) for a summary of the economy of Verapaz during the Late Postclassic period.

13. See Arnauld (1990:347-367, figs. 1 and 2), Demarest et al. (2007:19-47, fig. 1), Demarest et al. (2008:265-279), and Demarest et al. (2014:187-219, fig.1).

14. Rector-type center: that rules or governs. Classification proposed by Arnauld (1986: 43-51).

15. See Feldman (2000:172-73); Brady and Ashmore (1999).

16. This is an example of appropriation of sacred features of the landscape (the hill) in the architecture of Chich'en.

17. The damage was caused by the excavation of G. Léger. However, A. L. Smith did not report seeing the niche or the frame stones on the north side, mentioned in Léger's notes (Figure 19, Structure 2). Smith also reported damage to the top of Structure 6 (which Léger did not dig). Probably, the site was repeatedly looted.

18. With the publication of the field notes of G. Léger by Maertens de Noordhout (1930: 8), the funerary character of the pyramidal structure was confirmed.

19. During the visit to Chich'en in 2017, we observed that the slab is no longer on ballcourt (a). It stands against the south side of Structure 5 and is damaged at the top. The lower third of the slab is embedded in the ground, the relief is more eroded, and only the bird's crested head can be distinguished (Figure $20 \mathrm{c}$ ). Flat monuments were possibly removed from their original place and dropped nearby Structure 5, a few meters from the road. In 2010, a carved panel was discovered in Quiriguá alongside the Acropolis of the East Group. It shows a ballgame scene with four personages. One of the players wears a headdress with the head of a crested bird - maybe a cojolita, Penelope purpurascens or a pajuil, Crax rubra - that is also seen on vases K5913 and K1209 from the Justin Kerr Maya Vase Collection (Crasborn et al. 2011:6-7; fig.4).

20. In 2013, at the archaeological site of Chactún, in the eastern part of the Mexican state of Campeche, stone monuments with reliefs modeled in stucco, still with traces of red paint, were discovered. These 'plain stelae' had glyphs and other stucco designs, which were modeled and placed on the surface of the stone.

Some glyphs were engraved in stone, but later covered with those made in stucco, while other designs seem to have been modeled only in stucco (Esparza Olguín 2015:41-84). 
21. When Hernán Cortés and his 500 soldiers reached the coast of the Gulf of Mexico and advanced into the Mexican country, a smallpox epidemic gradually spread inland and decimated the densely populated city of Tenochtitlan in 1520, reducing its population by 40 percent in a single year. The Aztec capital surrendered in August 1521. This clash with the Aztec empire had less to do with weaponry, tactics, and strategy than with the ravages of disease.

22. Florine Asselbergs, Conquered Conquistadors: The Lienzo de Quauhquechollan, A Nahua Vision of the Conquest of Guatemala. Leiden University, The Netherlands, 2004.

23. The Quauhquechollans settled in the city of Santiago de Guatemala in the Valley of Almolonga. Their identity had been transformed through their alliance with the Spaniards and by the glory of their 'conquest of Guatemala' at the side of Jorge Alvarado. This gave them a privileged position in their new land.

24. Today, the Departments of Alta Verapaz, Baja Verapaz, and Izabal.

25. Fray Antonio de Remesal, Historia de la Provincia de San Vicente de Chiapas y Guatemala (1619, vol. I:169), cited in Van Akkeren (2002:69).

26. Op. cit., vol. I:191, cited in Van Akkeren (2002:70).

27. Fray Bartolomé de Las Casas, Del único modo de atraer a todos los pueblos a la verdadera religión. México: Fondo de Cultura Económica, Colección Popular [Segunda Edición], 1975:22, cited in Van Akkeren (2002:70).

28. Fray Antonio de Remesal, op. cit., in Van Akkeren (2002:70-72).

29. According to Estrada Monroy (1979:160, footnote 173), Sakq'uim is a place that is relatively close to the neighborhood (barrio) of San Luis, in San Juan Chamelco.

30. The village of Chamil is located $18 \mathrm{~km}$ east of San Juan Chamelco (Van Akkeren 2012:83).

31. This is a summary of Estrada Monroy's account of the foundation of San Juan Chamelco (1979:168-174). Unfortunately, the author does not always mention or specify his sources. Contextual information possibly came from other colonial documents available to the author, or from the oral tradition.

32. There is a chapel known as Ermita del Soldado, situated in Barrio San Luis, to the northeast of San Juan Chamelco. According to the oral tradition, this chapel is more than 500 years old. It has wall paintings which were repainted several times. See Rodríguez Girón (2009:117-132) for the full report, available at www.asociaciontikal.com/simposio-22-ano-2008/009-zoila-08-doc/

33. The Postclassic title Ah pop or Aj pop, "He of the Mat", is synonymous with ahaw or lord. Don Juan Matac B'atz, or Ajpo B'atz, belonged to the B'atz lineage, a lineage with a long history that ruled Tezulutlán (Van Akkeren 2012:146). B'atz means howler monkey. 
34. Because of language corruption, he is currently known as Don Juan Ma Tal B'atz or Matal B'atz (Estrada Monroy 1979:172).

35. The original copy of the Popol Vuh, was written in K'iche' with the Latin alphabet between 1555 and 1558. That document has been lost. The only known copy available is the transcription made at the beginning of the 18th century by the Dominican friar Francisco Ximénez (Christenson 2003:39-42; Van Akkeren 2003:254).

36. See Barlow and Ramírez (1962); Cruz Torres (1978:63-64); Díaz de Salas (1963:260); Galinier (1990:693-699); Guzmán (2002:143); Ichon (1973:66); Lupo (1991); Münch Galindo (1992); Oropeza Escobar (2007:183-185, 202-208, 214223); Petrich and Ochoa García (2001:32), cited in Chinchilla Mazariegos (2018:29-53).

37. In Boot, Erik. 2011. Fray Diego de Landa y la cosmovisión maya-yucateca a inicios del período colonial, pp. 76. Available at www.academia.edu/1601864/ Fray_Diego_de_Landa_y_la_cosmovisi\%C3\%B3n_mayayucateca_a_inicios_del_ per\%C3\%ADodo_colonial_2011_

38. Op.cit., pp. 61.

39. Robert M. Hill, II, 2001. Los Kaqchikeles de la época colonial. Adaptaciones de los Mayas del altiplano al gobierno español, 1600-1700.

40. The agglomeration of Chich'en was settled south of Chi Mon'a (Cobán today), and the agglomeration of Xucaneb on the northern slopes of the Xucaneb massif, south of San Juan Chamelco.

41. This colonial Q'eqchi' manuscript, contains several documents. It was discovered by the Belgian Father Esteban Haeserijn, in 1973, and has details of the Dominican missionary journey in the lands of Tezulutlán. The manuscript was translated by Haeserijn with the help of Don Tomás Cuc. Agustín Estrada Monroy (1979) made a paleographic transcription of the Q'eqchi' texts.

42. This is a summary of Estrada Monroy's description of the visit to the Spanish Court (1979:194-198). See also footnote 31, page 38.

43. See Miralbés de Polanco and Knoke de Arathoon 2003:46-71; fig. 2.3, 2.4), for a review of pre-Columbian and colonial Maya dress.

44. Note that the Verapaz region is the natural habitat of the quetzal bird. In preColumbian times, Verapaz was an important source of quetzal feathers in Mesoamerica.

45. Q'eqchi' people believe that all things and living beings must be treated according to their nature. Every person recognizes that evil deeds towards animals, for example, are known to Tzuul-Taq'a, Señor Cerro-Valle, who may send a punishment to remind those who have committed a fault, that they must immediately repair the damage (Estrada Monroy 1979:197). 
46. Especially on ceremonial garments used in the cofradía during the 20th century (Montoya 2003, 2011 a, and 2011 b).

47. This 'cellar' (cavity, vault, or chamber) was possibly a receptacle for offerings. Similar structures are seen in other sites, for example in Caracol (Chase and Chase 1998: 306-307; fig. 3).

48. This type of sarcophagus has been found in Baja Verapaz, see Sharer and Sedat (1987:pl. 8.2; pl. 4.3). Flat stones of the type described here were also seen by the author at a burial in the site Las Pacayas, San Cristóbal Verapaz, in 2017.

49. Rattle-type vessel feet (supports) see figure 29.

50. See also Gillespie (2002).

51. Stone and Zender (2011:81). See pages 81-83 of this report.

52. The Tikal Burial 116 vessel is inscribed with the ruler's name Jasaw Chan K'awiil. The inscriptions of the Chich'en polychrome lidded vessels are likely also name tags of a lord (Bassie-Sweet, personal communication, 2019). See also Hellmuth (1967:177-180).

53. See Figure 45, object number EVUG GE 80.143.1. Green obsidian sources are located in Mexico.

54. These observations about Huracan, the 'one-footed god,' attest the continuity of these ancient concepts and, as oral tradition does, Maya textile designs may be representations of cosmogonical ideas.

55. See Montoya (2020:81-82). Available at https://digitalcommons.unl.edu/actas2019/1

56. The Palenque Cross Group is composed of three temples/pyramids that flank a small plaza. A small, radial pyramid platform marks the center of the plaza as the center of the world (Taube 1998:441). Each of the three Cross Group temples/ pyramids focuses on one member of the Palenque triad-gods. God Gl is featured in the Temple of the Cross, god GII in the Temple of the Foliated Cross, and GIII in the Temple of the Sun. Inside each temple there is a small sanctuary, and on the back wall of each sanctuary is a tablet that describes the birth and activities of its respective god (Bassie-Sweet 2008:108). Stuart (2006) notes that the Cross Group pyramids are symbolic mountains, and he equates the sanctuaries with mountain caves that are also viewed by the Maya as houses of deities.

57. The representation on the potsherd EVUG GE I 00078 from Chich'en (Figure 52 a), is similar to that of the staircase of Copán. In both cases, their feline ears are broken. However, the skin spots are partially visible in the second case. 
58. The Mayan oral tradition played a determining role in textile iconography during the first half of the 20th century. In a study of textile motifs on huipiles (blouses) from places where the myth of the Sun and the Moon, or its variants, was known (areas Q'eqchi', Poqomchi', Ixil, K'iche', Kaqchikel and Tz'utujil), a relationship between the textile motifs and the symbols of this myth was found. The huipiles from Q'eqchi', Poqomchi', and Ixil communities, dating between 1930 and 1960, are the ones with the highest number of motifs directly related to the symbols of this myth (Montoya 2010:93-108).

59. Bartolomé de Las Casas, Apologética Historia Sumaria. Edmundo O'Gorman (ed.). 1967, vol. I:650. Instituto de Investigaciones Históricas, UNAM, México.

60. See performance of the Dance of Hunahpú and Xbalanqué at the founding of San Juan Chamelco, on page 45 of this report.

61. See Van Akkeren 2000 and 2012 for an extended analysis of the ethno-history, myths, and cultural traditions of Early Postclassic lineages that ruled Verapaz and the Northern Highlands of Guatemala.

62. See Popol Vuh, The Sacred Book of the Maya, by Allen J. Christenson, 2003.

63. The nal-sign, as well as the ek'-, lem-, ak'bal-, and jal-signs are 'word signs' or logographs, which represent an entire word in Maya writing (Stone and Zender 2011:11).

64. One of them is the magnificent headdress, known as "Penacho de Moctezuma" kept at the Weltmuseum, in Vienna.

65. Florentine Codex or "Historia general de las cosas de la Nueva España" by Bernardino de Sahagún and a group of Nahua co-authors (sages and painters), in the city of Tlatelolco, Mexico, between 1575 and 1577.

\section{Codex Magliabechiano, CL. XIII.3. FAMSI-Codices.}

67. Alfred Maudslay (1850-1931), was diplomat, explorer, archaeologist, and one of the first Europeans to study Maya culture. After 13 years of preparation, he published his findings in 1902 as a 5-volume compendium entitled Biologia Centrali-Americana, which had numerous drawings and photographs of Maya ruins. The photograph shown in Figure 26, page 47 of this report, comes from the publication A Glimpse at Guatemala, and Some Notes on the Ancient Monuments of Central America, 1899, by Anne Cary Maudslay and Alfred Percival Maudslay. 


\section{REFERENCES}

ADAMS, Abigail, and James E. BRADY, 2005.

Ethnographic Notes on Maya Q'eqchi' Cave Rites: Implications for Archaeological Interpretation. In In the Maw of the Earth Monster. Mesoamerican Ritual Cave Use. James E. Brady and Keith M. Prufer (eds.), pp. 30I-327. University of Texas Press, Austin.

ARNAULD, M. Charlotte, 1986.

Archéologie de L'Habitat en Alta Verapaz (Guatemala). Collections d'Etudes Mésoaméricaines, nr. Io. Centre D’Etudes Mexicaines et Centramericaines, Mexico.

, I978. Habitat et société préhispaniques en Alta Verapaz occidentale, Guatemala : Étude archéologique et ethnohistorique. Fournal de la Société des Américanistes 65:4I-62.

, 1990. El comercio clásico de obsidiana: rutas entre tierras altas y tierras bajas en el área maya. Latin American Antiquity I(4):347-367.

BARDAWIL, Lawrence W., I976.

The Principal Bird Deity in Maya Art: An Iconographic Study of Form and Meaning. In The Art, Iconography \& Dynastic History of Palenque, Part III. Proceedings of the Segunda Mesa Redonda de Palenque, 1974. Merle Green Robertson (ed.), pp. 195-209. Pre-Columbian Art Research/The Robert Louis Stevenson School, Pebble Beach, California.

BASSIE-SWEET, Karen, I99I.

From the Mouth of the Dark Cave. University of Oklahoma Press: Norman and London.

1996. At the Edge of the World. University of Oklahoma Press: Norman and London. 200o. Corn Deities and the Complementary Male/Female Principle. Revised

September 200o. Available at

www.mesoweb.com/features/bassie/corn/Corn_Deities.pdf 2002. Maya Creator Gods. Available at

www.mesoweb.com/features/bassie/CreatorGods/CreatorGods.pdf 2008. Maya Sacred Geography and the Creator Deities. University of Oklahoma Press: Norman.

2013. An Obsidian Merchant Deity. The Role of God L as a Patron Deity for Merchants and Traders of Obsidian, Fade and 2uetzal Feathers. Paper presented at the Chacmool Conference Trading Spaces, the Archaeology of Interaction, Migration and Exchange. University of Calgary. 2015. The Ch'ol Maya of Chiapas. Karen Bassie-Sweet (ed.). University of Oklahoma Press: Norman. 2019. Maya Gods of War. Boulder: University Press of Colorado. In press.

BECKER, Marshall, J. I993.

Earth Offering Among the Classic Period Lowland Maya: Burials and Caches as Ritual Deposits. In Perspectivas antropológicas en el mundo maya. María J. Iglesias Ponce de León and Frances Ligorred Perramon (eds.), pp. 45-74. Publicaciones de la Sociedad Española de Estudios Mayas, nr.2. Madrid. 
BERGER, Martin E., 20I9.

"From a Cave near Tehuacán." An Attempt to Reassemble Post-Classic Mesoamerican Ritual Deposits Separated by the Art Market. In The Market for Mesoamerica: Reflections on the Sale of Pre-Columbian Antiquities. Cara G. Tremain and Donna Yates (eds.). pp. II2-I35. Gainesville: University Press of Florida.

BOURBON, Fabio, I999.

The Lost Cities of the Mayas. The Life, art, and discoveries of Frederick Catherwood. Abbeville Press Publishers, New York - London.

BRADY, James E., and Wendy ASHMORE, 1999.

Mountains, Caves, Water: Ideational Landscapes of the Ancient Maya. In Archaeologies of Landscapes: Contemporary Perspectives. Wendy Ashmore and A. Bernard Knapp (eds.), pp. I24-I45. Blackwell Publishers, Oxford.

BRADY, James E., and Keith M. PRUFER, I999.

Caves and Crystalmancy: Evidence for the Use of Crystals in Ancient Maya Religion. Fournal of Anthropological Research, vol. 55 (I):I29-I44. Available at: http://links.jstor.org/sici?sici=009I-10\%28I99921\%2955\%3AI $\%_{3} \mathrm{CI}_{29} \% 3 \mathrm{ACACEFT} \%_{3} \mathrm{E}_{2.0 . C O} \%_{3} \mathrm{~B}_{2}-\mathrm{FACACEFT} \%_{3} \mathrm{E}_{2.0 . C O} \%_{3} \mathrm{~B} 2-\mathrm{F}$

BRADY, James. E., Ann SCOTT, Hector NEFF, and Michael D. GLASCOCK, 1997. Speleothem Breakage, Movement, Removal, and Caching: An Aspect of Ancient Maya Cave Modification. Geoarchaeology I2(6):725-750. Available at https://doi.org/IO.IO02/(SICI)I520-6548(I99709)I2:6<725::AID-GEAro>3.0.CO;2-D

BURKITT, Robert, I920.

The Hills and the Corn. University of Pennsylvania - The University Museum, Anthropological Publications, vol.VIII no. 2. Philadelphia.

CARLSEN, Robert S., and Martin PRECHTEL, I99I. The Flowering of the Death: An Interpretation of Highland Maya Culture. Man 26 (I991):23-42.

CARMACK, Robert M., and James L. MONDLOCH, I983 [1554].

Título de Totonicapán (edición facsimilar, transcripción y traducción). Universidad Nacional Autónoma de México/ Instituto de Investigaciones Filológicas, pp. 178, 221-222. México.

CARRASCO, Michael D., 2005.

The Mask Flange Iconographic Complex: The Art, Ritual, and History of a Maya Sacred Image. Ph.D. Thesis. The University of Texas, Austin. Available at www.academia.edu

CASO BARRERA, Laura, and Mario ALIPHAT, 2007.

Relaciones de Verapaz y las Tierras Bajas Mayas Centrales en el siglo XVII. In XX Simposio de Investigaciones Arqueológicas en Guatemala, 2006. J.P. Laporte, B. Arroyo and H. Mejía (eds.), pp. 48-58. Museo Nacional de Arqueología y Etnología, Guatemala. 
CHASE, Diane Z., and Arlen F. CHASE, 1998.

The Architectural Context of Caches, Burials, and Other Ritual Activities for the Classic Period Maya (as Reflected at Caracol, Belize). In Function and Meaning in Classic Maya Architecture. S. D. Houston (ed.), pp. 299-332. Dumbarton Oaks, Washington, D-C.

CHINCHILLA MAZARIEGOS, Oswaldo, 2017.

Art and Myth of the Ancient Maya. Yale University Press, New Haven and London.

, 20I8. Fire and Sacrifice in Mesoamerican Myths and Rituals. In Smoke,

Flames, and the Human Body in Mesoamerican Ritual Practice. Andre Scherer and Vera Tiesler (eds.), pp. 29-53. Dumbarton Oaks, Washington D.C.

CHRISTENSON, Allen J., 20OI.

Art and Society in a Highland Maya Community. The Altarpiece of Santiago Atitlán. University of Texas Press, Austin. 2003. Popol Vub. The Sacred Book of the Maya. Books, United Kingdom/ New York. 2005. Dancing in the Footsteps of the Ancestors. In Lords of Creation: The Origins of Sacred Maya Kingship. Virginia M. Fields and Dorie ReentsBudet (eds.), pp. 90-96. Los Angeles County Museum of Art and Scala Publishers Ltd.

COLOP, Sam, 2008.

Popol Wuj. Editorial Cholsamaj, Guatemala.

CRASBORN, José, Elizabeth MARROQUín, Federico FAHSEN, and María E. VEGA, 2OII.

Un nuevo monumento en Quiriguá: la banca y panel tallados de la Estructura Ib-I4 del Grupo Este. XXV Simposio de Investigaciones Arqueológicas en Guatemala, Julio 20Ir. Available at www.academia.edu/31312570

DANIEN, Elin C., 2004.

Paintings of Maya Pottery: The Art and Career of M. Louise Baker. Reports submitted to FAMSI, 2006. Figures QI-3. Available at www.famsi.org/reports/03029/03029DanienImages.pdf

DE BORHEGYI, Stephan F., I965.

Settlement Patterns of the Guatemalan Highlands. In Handbook of Middle American Indians. Archaeology of Southern Mesoamerica, volumes 2 and 3. Robert Wauchope and Gordon R. Willey (eds.), pp. 59-75. University of Texas Press.

DEMAREST, Arthur, Brent WOODFILL, Tomás BARRIENTOS, Mirza MONTERROSO, and Federico FAHSEN, 2007.

La ruta Altiplano-Tierras Bajas del Occidente y el surgimiento y caída de la civilización maya del Clásico. In XX Simposio de Investigaciones Arqueológicas en Guatemala, 2006. J.P. Laporte, B. Arroyo and H. Mejía (eds.), pp. 19-47. Museo Nacional de Arqueología y Etnología, Guatemala. 
DEMAREST, Arthur, Brent WOODFILL, Marc WOLF, Tomás BARRIENTOS, Ronald BISHOP, Mirza MONTERROSO, Edy BARRIOS, Claudia QUINTANILLA, and Matilde IVIC DE MONTERROSO, 2008.

De la selva a la sierra: Investigaciones a lo largo de las rutas ribereñas y terrestres del Occidente. In XXI Simposio de Investigaciones Arqueológicas en Guatemala, 2007. J. P. Laporte, B. Arroyo and H. Mejía (eds.), pp. 265-279. Museo Nacional de Arqueología y Etnología, Guatemala.

DEMAREST, Arthur, Chloé ANDRIEU, Paola TORRES, Mélanie FORNÉ, Tomás BARRIENTOS, and Marc WOLF, 2014.

Economy, Exchange, and Power: New Evidence from the Late Classic Maya Port City of Cancuén. Ancient Mesoamerica, 25:187-219. Available at http://journals.cambridge.org/abstract_So956536II4000I2I

DIESELDORFF, Erwin P., I909.

Klassifizierung seiner archäologischen Funde im nördlichen Guatemala. Zeitschrift für Ethnologie 41:862-874. , 1926. Kunst und Religion der Mayavölker im Alten und Heutigen Mittelamerika. Verlag von Julius Springer, Berlin.

ESPARZA OLgUín, Octavio, 2015.

Documentación de los monumentos esculpidos de Chactún (Capítulo 4). In Exploraciones arqueológicas en Chactún, Campeche, México. Ivan Šprajc (ed.). Inštitut za Antropološke in Prostorske Študije, ZRC SAZU, Ljubljana.

ESTRADA MONROY, Agustín, I979.

El mundo k'ekchi' de la Vera-Paz. Editorial del Ejército, Guatemala.

FELDMAN, Lawrence H., (ed.), 2000.

Lost Shores, Forgotten Peoples. Spanish Explorations of the South East Mayan Lowlands. Duke university Press, Durham/London.

FIELDS, Virginia M., Dorie REENTS-BUDET, (eds.), 2005. Lords of Creation: The Origins of Sacred Maya Kingship. Los Angeles County Museum of Art/Scala Publishers Limited.

FREIDEL, David, Linda SCHELE, and Joy PARKER, I993.

Maya Cosmos. Three Thousand Years on the Shaman's Path. William Morrow and Company, Inc. New York.

FRISCHMANN, Donald, 2007.

Buscando el equilibrio. Teatro indígena en la conjunción de milenios. In Palabras de los Seres Verdaderos. Tomo tres: Teatro. Carlos Montemayor and Donald Frischmann (eds.), pp. 48-77. University of Texas Press, Austin.

GILLESPIE, Susan D., 2002.

Body and Soul among the Maya: Keeping the Spirits in Place. In "The Space and Place of Death". H. Silverman and D. Small (eds.). Archeological Papers of the American Anthropological Association II(I):67-78. 
GUTIERREZ, Mary E., I993.

Ballcourts: The Chasms of Creation. Texas Notes on Pre-Columbian Art, Writing, and Culture No. 53, $\mathrm{I}^{-} 3$. Texas.

HELLMUTH, Nicholas M., I967.

Structure 5d-73, Burial 196, Tikal, Petén, Guatemala. A Preliminary Report, Harvard Thesis. Foundation for Latin American Anthropological Research, Florida.

HELMKE, Christophe, and Felix KUPPRAT, 2017.

Los glifos emblema y los lugares sobrenaturales: el caso de Kanu'l y sus implicaciones/Emblem Glyphs and Supernatural Places: The Case of Kanu'l and its Implications. Estudios de cultura maya 50(I):95-135.

HILL, II, Robert M., 200I.

Los kaqchikeles de la época colonial. Adaptaciones de los mayas del altiplano al gobierno español, I600-170o. Plumsock Mesoamerican Studies/ Editorial Cholsamaj, Guatemala.

HIRTZEL, J. S. Harry, I925.

Collections d'Antiquités Guatémaltèques du Musée d'Archéologie de l'Université de Gand. Actas del XXI Congreso Internacional de Americanistas, pp. 668-672. Göteborg.

HOLSBEKE, Mireille, and Julia MONTOYA (eds.), 2003. With Their Hands and Their Eyes: Maya Textiles, Mirrors of a Worldview. Etnografisch Museum, Antwerpen. , 2008. Kemtzij Kemon Taq Tzij Na'Oj: Palabras y pensamientos tejidos Los tejidos mayas: Espejos de una cosmovisión. Etnografisch Museum Antwerpen/Fundació Caixa de Girona/Cholsamaj, Guatemala.

HOUSTON, Stephen, 20I4. Deathly Sport. Maya Decipherment, Monthly Archives: July 20I4. Available at https://mayadecipherment.com/20I4/o7/

HOUSTON, Stephen, Claudia BRITTENHAM, Cassandra MESICK, Alexandre TOKOVININE, and Christina WARINNER, 2009.

Veiled Brightness: A History of Ancient Maya Color. University of Texas Press, Austin.

HOUSTON, Stephen, David STUART, and Karl TAUBE, 2006. The Memory of Bones. Body, Being, and Experience among the Classic Maya. University of Texas Press, Austin.

KISTLER, S. Ashley, 2013.

The Original Ancestor: Aj Pop B'atz' as a Model of Q'eqchi' Kinship. Fournal of Family History oo(o): $\mathrm{I}^{-} \mathrm{I} 7$. Available at http://biblio3.url.edu.gt/Publi/Libros/20I4/BiblioFrayBC/JournalFHisto.pdf 
LE FORT, Geneviève (red.), 2005.

Precolumbiaanse meesterwerken. De collectie van Dora en Paul Janssen. Mercatorfonds, Brussel \& 5 Continents Editions, Milaan.

LOOPER, Matthew G., 2003.

Maya Art and Kingship at Quiriguá. University of Texas Press, Austin.

LOTHROP, Samuel K., 1936.

Zacualpa. A Study of Ancient 2uiché Artifacts. Carnegie Institution of Washington. Publication 472.

MAERTENS DE NOORDHOUT, Joseph, I930.

Fouille de deux tumuli à Chichen, Guatemala. Extrait du Bulletin de la Société d'Histoire et d'Archéologie de Gand. pp. 5-I4. Siffer, Gand.

MAGALONI KERPEL, Diana, 2020.

El Códice Florentino y la creación del Nuevo Mundo. Arqueología Mexicana, Edición especial No. 90.

MARTIN, Simon, and Nikolai GRUBE, 2000.

Chronicle of the Maya Kings and Queens. Deciphering the Dynasties of the Ancient Maya. Thames \& Hudson Ltd. London.

MATTON, Isabelle, 2015.

Commercial Neo-Colonialism in Guatemala: From Collective Attempts to Individual Initiatives. A Study Case of Colonial and Postcolonial Urbanism. University of Louvain (KUL), Department of Architecture.

MAUDSLAY, Anne C., and Alfred P. MAUDSLAY, i899.

A Glimpse at Guatemala, and Some Notes on the Ancient Monuments of Central America. Available at http://www.gutenberg.org/files/47693/47693-h/47693-h.htm\#CHAPTER_XI

MAZA GARCíA DE ALBA, Rocío, 2019.

Pisom q'aq'al: la majestad envuelta. Poder, reliquias y el "poder de las reliquias" entre los mayas prehispánicos. Estudios de Cultura Maya LIII. pp. 173- 204.

MCANANY, Patricia A., 1995.

Living with the Ancestors. Kinship and Kingship in Ancient Maya Society.

University of Texas Press, Austin.

MILLER, Mary, and Simon MARTIN, 2004.

Courtly Art of the Ancient Maya. Fine Arts Museum of San Francisco, Thames \& Hudson.

MILLER, Mary, and Karl TAUBE, 1993.

The Gods and Symbols of Ancient Mexico and the Maya. Thames \& Hudson. 
MIRALBÉS DE POLANCO, Rosario, and Barbara KNOKE DE ARATHOON, 2003. Survival Strategies: The Diversity of Maya Dress in Guatemala. In With Their Hands and Their Eyes: Maya Textiles, Mirrors of a Worldview. Holsbeke M. and J. Montoya (eds.), pp. 47-7r. Etnografisch museum, Antwerpen.

MONTERROSO, Mirza, 2007.

Investigaciones en el norte de Alta Verapaz: El sitio arqueológico La Lima. In XX Simposio de Investigaciones Arqueológicas en Guatemala, 2006. J. P. Laporte, B. Arroyo and H. Mejía (eds.), pp. 310-330. Museo Nacional de Arqueología y Etnología, Guatemala.

MONTOYA, Julia, 2003.

Maya Textile Motifs: Mirrors of a Worldview. In With Their Hands and Their Eyes: Maya Textiles, Mirrors of a Worldview. Holsbeke M. and J. Montoya (eds.), pp. 93- I27. Etnografisch Museum, Antwerpen. , 20II (a). Los mitos de Creación y su representación en los textiles mayas. In Actas de las V Fornadas Internacionales de Textiles Precolombinos, 2010. V. Solanilla Demestre (ed.), pp. 93- ro8. Grup d'Estudis Precolombins Universitat Autónoma de Barcelona.

, 20II (b). Elementos cosmogónicos en prendas ceremoniales mayas. La paya de cofradía, Patzún, Guatemala. In Las imágenes precolombinas, reflejos de saberes. Valverde Valdéz, M. C., and V. Solanilla Demestre (coords.), pp. 279-305. Universidad Nacional Autónoma de México, México. , 2018. De geschiedenis van een vergeten verzameling. Een Mayacollectie in België. In Achter de Schermen. VVV Faarboek, nr. 6. A. Wentholt (ed.), pp. 16-35. Nederland.

, 2020. Contextualizando una colección maya olvidada proveniente de Chich'en, Cobán, Alta Verapaz, Guatemala. In Congreso internacional sobre iconografia precolombina, Barcelona 2019. Actas. Victoria Solanilla Demestre (ed.), pp. 72-88. Zea Books, University of Nebraska-Lincoln Libraries. Available at https:/digitalcommons.unl.edu/actas2019/I/

NEUTZE de RUGG, Carmen, 1976.

Diseños en los tejidos indígenas de Guatemala. Colección Problemas y Documentos vol.4. Universidad de San Carlos de Guatemala.

PÉREZ SUÁREZ, Tomás, 2013.

Los olmecas y los dioses del maíz en Mesoamérica. In De hombres y dioses. Xavier Noguez and A. López Austin (coords.), pp. 15-49. Gobierno del Estado de México (FOEM)/ El Colegio de Michoacán, A.C./El Colegio Mexiquense, A.C. México.

PITMAN, Bonnie, 2012.

Lidded Bowl with a Man Riding a Peccary (i972.Io. a-b). In Dallas Museum of Art: A Guide to the Collection. pp. 42. New Haven, Yale university Press. 
RECINOS, Adrián, I950.

Popol Vuh. The Sacred Book of the Ancient 2uiché Maya.

Translation to English by Delia Goetz and Sylvanus G. Morley. Norman, University of Oklahoma Press.

REENTS-BUDET, Dorie, 1994.

Painting the Maya Universe: Royal Ceramics of the Classic Period. Duke University Museum of Art. Duke University Press, Durham \& London.

ROBICSEK, Francis, 1978.

The Smoking Gods. Tobacco in Maya Art, History and Religion. University of Oklahoma Press: Norman.

RODRÍGUEZ GIRÓN, Zoila, 2009.

La Ermita del Soldado, San Juan Chamelco,Alta Verapaz. In XXII

Simposio de Investigaciones Arqueológicas en Guatemala, 2008. J.P. Laporte, B. Arroyo and H. Mejía (eds.), pp. II7-I32. Museo Nacional de Arqueología y Etnología, Guatemala. Available at www.asociaciontikal.com/simposio-22-ano-2008/oo9-zoila-o8-doc/

ROMERO SANDOVAL, Roberto, 2017.

El inframundo de los antiguos mayas. Universidad Nacional Autónoma de México, México.

RUIZ PÉREZ, Diego, 2018.

Los tres rostros del "Dios Bufón". Iconografía de un símbolo de poder de los gobernantes mayas durante el período Clásico (250-950 D.C.), Tesis de Maestría. Universidad Nacional Autónoma de México/Instituto de Investigaciones Filológicas, México. Available at www.academia.edu/372I2339

RUSEK, Magdalena H., Jaroslaw ZRAŁKA, and Bernard HERMES, 2014. Análisis de los artefactos de jade del sitio arqueológico Nakum. In XXVII Simposio de Investigaciones Arqueológicas en Guatemala, 2013. B. Arroyo, L. Méndez Salinas and A. Rojas (eds.), pp. 299-312. Museo Nacional de Arqueología y Etnología, Guatemala.

SAHAGÚN, Bernardino de., I979.

Códice Florentino de Fray Bernardino de Sahagún. Edición facsimilar. Volumen III. Casa Editorial Giunti Barbèra, Florencia.

SAPPER, Carl [Karl], I895.

Altindianische Ansiedelungen in Guatemala und Chiapas. Veröffentlichungen aus dem Königlichen Museum Für Völkerkunde, IV, I895:I8. Berlin.

SAPPER, Karl, Eduard SELER, and Franz TERMER, 1998.

Estudios Q'eqchi'es de etnógrafos alemanes en las Verapaces. Edited by Rancho Palos Verdes, CA -Yax Te' Foundation. 
SCHELE, Linda, and Mary E. MILLER, 1986.

The Blood of Kings. Dynasty and Ritual in Maya Art. Kimberly Art Museum, Fort Worth.

SELER, Eduard, I904.

Antiquities of Guatemala. In Mexican and Central American Antiquities, Calendar Systems, and History. Smithsonian Institution, Bulletin 28, pp. 75-12I. Washington. 20I8. Antiquities of Guatemala. In Mexican and Central American

Antiquities, Calendar Systems, and History. FB \&c Ltd, London. Available at www.forgottenbooks.com

SHARER, Robert, and David SEDAT, 1987.

Archaeological Investigations in the Northern Maya Highlands, Guatemala. Interaction and Development of Maya Civilization. University Museum, Monograph 59. University of Pennsylvania, Philadelphia.

SHARER, Robert J., and Loa P. TRAXLER, 2006.

The Ancient Maya. Stanford University Press.

SMITH, A. Ledyard, I955.

Archaeological Reconnaissance in Central Guatemala. Carnegie Institution of Washington, Publication 6o8. Washington D.C.

SMITH, Robert E., 1952.

Pottery from Chipoc, Alta Verapaz, Guatemala. Carnegie Institution of Washington, Publication 596, vol. XI, pp. 217-236.

SPINDEN, Herbert J., I975.

A Study of Maya Art. Its Subject Matter and Historical Development. Dover Publications, Inc., New York.

STEPHENS, John L., I969 [I84I].

Incidents of Travel in Central America, Chiapas, and Yucatan. Dover

Publications, Inc., New York.

STONE, Andrea, and Marc ZENDER, $201 \mathrm{I}$.

Reading Maya Art. A Hieroglyphic Guide to Ancient Maya Painting and Sculpture. Thames and Hudson.

STUART, David, I998.

"The Fire Enters His House": Architecture and Ritual in Classic Maya Texts. In Function and Meaning in Classic Maya Architecture. Stephen D. Houston, (ed.). Dumbarton Oaks Trustees for Harvard University Washington D.C. Available at www.doaks.orgetexts.html 2006. The Palenque Mythology. Inscriptions from the Cross Group at Palenque. In Sourcebook for the 2006 Maya Meetings, pp. 85-194. Department of Art and Art History, University of Texas at Austin. 
, 20Io. Shining Stones. Observations on the Ritual Meaning of Early Maya Stelae. In The Place of Stone Monuments. Context, Use, and Meaning in Mesoamerica's Preclassic Transition. Julia Guernsey, John E. Clark, and Barbara Arroyo (eds.), pp. 283-298. Dumbarton Oaks Research Library and Collection, Washington, D.C.

, 2013. The Name of the Paper: The Mythology of Crowning and Royal Nomenclature on Palenque's Palace Tablet. Maya Archaeology 2:II8-I48. 2015. Earth-caves and Sky-caves: Intersections of Landscape, Territory and Cosmology among the Ancient Maya. The University of Texas at Austin. Available at www.academia.edu/35070038

TAUBE, Karl, 2018 [1985].

The Classic Maya Maize God: A Reappraisal. In Studies in Ancient Mesoamerican Art and Architecture: Selected Works by Karl Andreas Taube, pp. 76-93. PreColumbian Mesoweb Press, San Francisco. Available at www.mesoweb.com/publications/Works , 1992. The Major Gods of Ancient Yucatan. Dumbarton Oaks, Washington D.C. , 2005. The Symbolism of Jade in Classic Maya Religion. Ancient Mesoamerica $16: 23^{-} 50$.

TAUBE, Rhonda B., 2009 Dancing in the Altiplano: K'iche' Maya Culture in Motion in Contemporary Highland Guatemala. Ph.D. Thesis. University of California, San Diego. Available at www.academia.edu/42IO27/

TEDLOCK, Dennis, 1996.

Popol Vuh. The Mayan Book of the Dawn of Life. Simon \& Schuster, New York.

TOKOVININE, Alexandre A., 2008.

The Power of Place: Political Landscape and Identity in Classic Maya Inscriptions, Imagery, and Architecture. Ph.D. Thesis. Harvard University Cambridge, Massachusetts. Available at https//www.academiapress.edu/3103045

TUROK, Marta, 1976 .

Diseño y símbolo en el huipil ceremonial de Magdalenas, Chiapas. Departamento de Investigación de las Tradiciones Populares. Dirección General de Arte Popular, Secretaría de Educación Pública, pp. I22-ı36. México.

UNIVERSIDAD FRANCISCO MARROQUÍN (UFM), 2007.

El Lienzo de la conquista / Quauhquechollan / A Chronicle of Conquest. Catalog. Elizabeth Hanckel (ed.), Universidad Francisco Marroquín, Guatemala.

VALDÉS, Juan A., 1996.

El período Clásico en las Tierras Bajas. In Piezas maestras mayas. Patrimonio del Museo nacional de Arqueología y Etnología de Guatemala. Galería Guatemala III, pp. 76-85. Fundación G\&T, Guatemala. 
VALENCIA RIVERA, Rogelio, and Ana GARCÍA BARRIOS, 20 Io.

Rituales de invocación al dios K'awiil. In El ritual en el mundo maya: de lo privado a lo público. A. Ciudad Ruiz, Ma. J. Iglesias and M. Sorroche (eds.), pp. 235-26r. Publicaciones de la Sociedad Española de Estudios Mayas, Publicación 9, Madrid.

VALENCIA RIVERA, Rogelio, 20 II.

La abundancia y el poder real: el dios K'awiil en el Posclásico. Instituto de Estudios Ibéricos e Iberoamericanos de la Universidad de Varsovia / Institut de Recherches Intersites Études Culturelles, Universidad de Toulouse, pp. $67^{-9} 96$.

, 2013. Las múltiples caras de la divinidad. Complejos de dioses en la religión maya. In Religión maya: rasgos y desarrollo histórico. Alejandro Sheseña (ed.). pp. 225-238. Colección Selva Negra, Unicach. Tuxtla Gutiérrez.

, 20I6. El rayo, la abundancia y la realeza. Análisis de la naturaleza del dios K'awiil en la cultura y la religión mayas. Tesis de Doctorado. Universidad Complutense de Madrid.

20I8. Los nombres sagrados del rey: El análisis semántico de los atributos de una deidad a través de la onomástica. In Tiempo detenido, tiempo suficiente. Ensayos y narraciones mesoamericanistas en homenaje a Alfonso Lacadena García. H. Kettunen, V. Amellali Vázquez López, F. Kupprat, C. Vidal Lorenzo, G. Muñoz Cosme and M. J. Iglesias Ponce de León (eds.). pp. 509545. European Association of Mayanists, WAYEB.

VAN AKKEREN, Ruud, 2000.

Place of The Lord's Daughter. Rab'inal, its History, its Dance-Drama. CNWS, Leiden University. , 2002. Lugar del Cangrejo o Caracol: La fundación de Rab'inal-Tequicistlán, Guatemala. Mesoamerica 44:54-8I. 2003. Authors of the Popol Wuj. Ancient Mesoamerica I4 (2):237 256. , 2010. Fray Domingo de Vico: Maestro de Autores Indígenas. The Mayan Studies fournal/Revista de Estudios Mayas, 2(7): I-6I. 2012. Xib'alb'a y el nacimiento del Nuevo Sol. Una visión posclásica del colapso maya. Editorial Piedra Santa, Guatemala.

VANDENHOUTE, J., and H. BURSSENS, 1968.

De Etnografische Verzamelingen. Seminaries voor Primitieve Kunst, Etnologie en Volkskunde, Rijksuniversiteit Gent.

VELÁSQUEZ GARCÍA, Erik, 2015.

El juego de pelota entre los mayas del período Clásico (250-900 d.C.). Algunas reflexiones. In El juego de pelota mesoamericano; temas eternos nuevas aproximaciones. M. T. Uriarte (ed.), pp. 25- 326. Instituto de Investigaciones Estéticas, UNAM, México.

VOGT, Evon, and David STUART, 2005.

Some Notes on Ritual Caves among the Ancient and Modern Maya. In In the Maw of the Earth Monster. Mesoamerican Ritual Cave Use. James E. Brady and Keith M. Prufer (eds.), pp. 155-I85. University of Texas Press, Austin. 
WAGNER, Regina, 200I.

Historia del café de Guatemala. Anacafé/Villegas Editores, Guatemala.

WATANABE, John M., I990.

From Saints to Shibboleths: Image, Structure, and Identity in Maya

Religious Syncretism. American Ethnologist I7 (I):I3I-150.

WILSON, Richard, I993.

Anchored Communities: Identity and History of the Maya-Q'eqchi'. Man 28(I):I2I-I38.

WINZENZ, Karon, 2008.

A Study of Sacred Bundles, Bundling Practices, and Bundling Rituals on Classic Maya Ceramic Vessels. Thesis. The University of Wisconsin, Milwaukee, pp. I-193. Available at https://www.academia.edu/37637225/

WOODFILL, Brent, 2005.

Archaeological Investigations in the Candelaria Caves and La Lima, Alta Verapaz, Guatemala. Available at www.famsi.org , 20II. The Central Role of Cave Archaeology in the Reconstruction of Classic Maya Culture History and Highland-Lowland Interaction. Ancient Mesoamerica 22:213-227.

WOODFILL, Brent, Federico FAHSEN, and Mirza MONTERROSO, 2006.

Nuevos descubrimientos y evidencia de intercambio a larga distancia en Alta Verapaz, Guatemala. In XIX Simposio de Investigaciones Arqueológicas en Guatemala, 2005. J.P. Laporte, B. Arroyo and H. Mejía (eds.), pp. I044-I057. Museo Nacional de Arqueología y Etnología, Guatemala.

Broken head from a vessel lid, see page 80. 


\section{ANNEXES}

\section{ANNEX 1}

\section{GEORGES LÉGER'S LETTER}

\section{AND FIELD NOTES}

\section{Letter from Georges Léger}

to Mr. Wolbers, Administration Inspector of the University of Ghent.

Date: November 15, 1895 (Copy).

\section{List of objects}

excavated in Chich'en by Georges Léger (Copy).

\section{Letter from Professor Adolf De Ceuleneer,} docent at the University of Ghent, to M. Wolbers.

Date: December Io, I895 (Copy).

\section{Field notes of Georges Léger, 1894}

Abstract from: Maertens de Noordhout, Jos, I930.

Fouille de deux tumuli a Chi-Chen, Guatemala (Amérique Centrale).

Extrait du Bulletin de la Societé d'Histoire et d'Archéologie de Gand. pp. 5-9.

W.Siffer, Imprimeur. Place St-Bavon Gand. 


\section{Letter from Georges Léger}

- An

3. Prudeder tarder.

$$
\text { Qpeie }
$$

France.

$$
\begin{aligned}
& \text { Honneme Bolters, } \\
& \text { Amminishatuer de t' thiversite' }
\end{aligned}
$$

Honsiar,

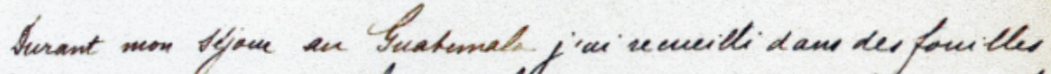
prationés par novi: meime un bon sombre d'antiquités amériesines fot intécessantes.

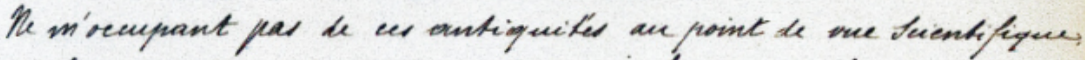
tt ne voulant upenaant par voin perabe les trouvailles que j"ai baites, ji préfiverais voir ees antiquites entre los nains de persomes qui pourraient sintéresser à elles.

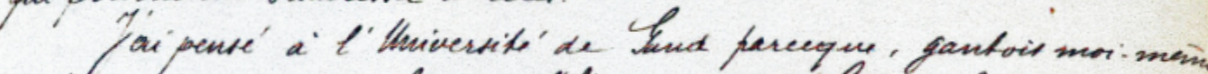

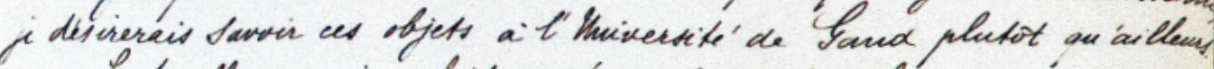
Lesfruilles que j'ci faites m'ayant couté quelque argent, je mued demanderai non pas la valeur des antiquitús qui quent ête trei grande.

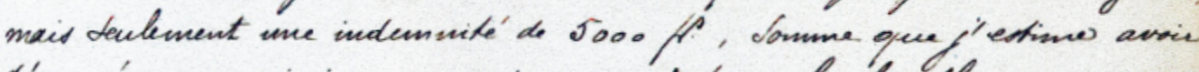
dípensié an minimum neiquement bour les forilles.

Prur vour faciliter cette opération je vaus propposerair le paie. - ment en disers epercices, pee esemple boo frances an comptant et

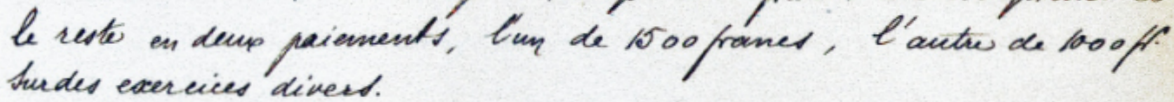

Monsieu Maudsby, le grand explorateur anglais, ent venu chy noi poun voir mes antiquiter aménicaimes, eld m'á astrué qu'll n'avait jamair siey veneontre' de tembletle. Mi le murei de

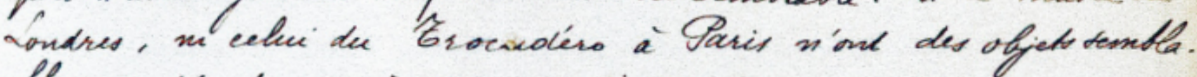
- bles on identiques à ceua que i posride.

'tent rai'que jai cherche' bà vì eux n'avaient jamair penre devoir trouver d'antiquités: je les ai trouve'es par Shite d'andications qui in ont éte faites daus des vaygags en Compognie d'anciens du rays que 'babitais et avec lesquels javair ve'en penocant biey e

Evous semets ci inclus une liste des ofjist que iaci dans mas eollection?

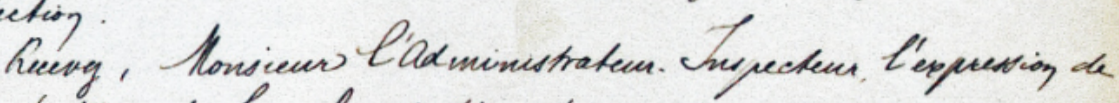
mes centiments hes plus distingueis. Ses. Ke'ges. 


\section{List of objects}

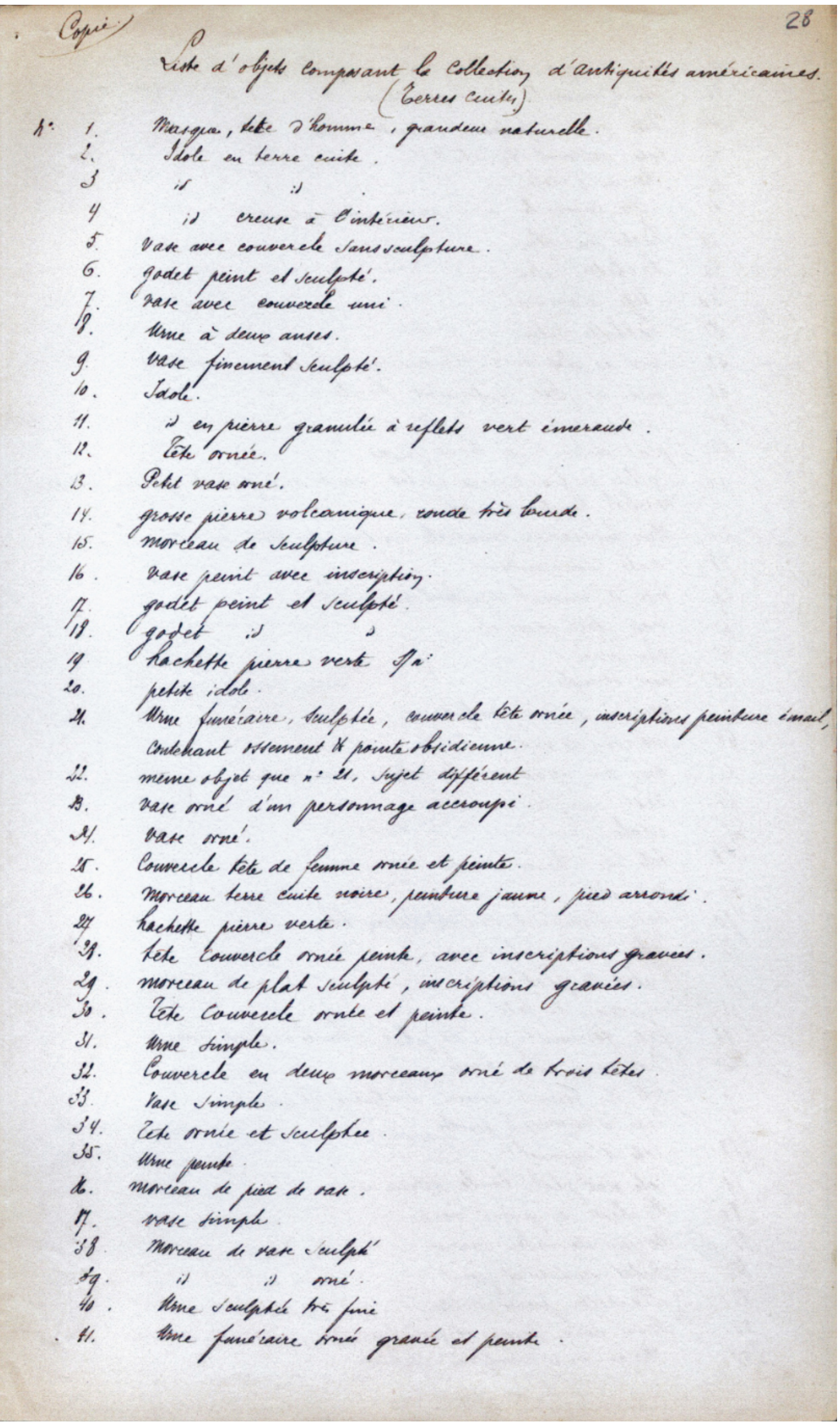


42. petit merque diablotin

4s. Tete a'meimal creure el vernie

"44 tète mné, Senlfuté et pevide

4\%. Hete animal tymbrlique

47. Tete couvercle arnte peinte, inseriptiones

49. hache en silep.

4. Rachette silex.

50. Lete a'animal.

5\%. hachette dilep.

52. pied de plat enee persmoage burlergue accroupi:

03. pied de plat esitenant baule.

54. hue is id

of. Alat entier sen trois vieas 56. Gollin perles pierrer rientes, dont une gravde gravie, of deup

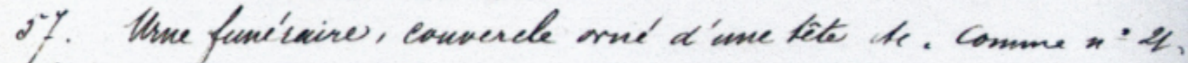

37. are sudimentaice

59. Tite d'minel tymbolique.

60. Tase enee convercle.

6/. vare mé.

62. sere etrangle'

65. morcean le sere Senlfote'.

64. morcean de rax i)

65. Hne trei encionse, Doulfture sudimentacie.

66. sere simple.

67 idole.

Ty. Hete de Chaum-sourit.

6q. here uni.

10. vare fimement sculpoté destin blen.

fi. pled de plat rone.

13. morcean de tete

71. Tete formant fied de plat, haulei l'mb'rever.

15. Cied ereup aree toude?

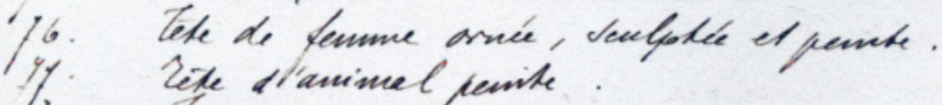

Is. Ele dianimel parite.

ty. Tete piedeletat, haule intéveinse

So dachethe en piene verte

81. Mroeau de Tiles arrondi

1'. Ioded seculpte' et pent.

ti. Hackette pierve veste.

14. Hine avec dernin et peinture.

15. Hone ince vecefile epenite 
16. Converele de raves.

67. Zote d'idole

11. Vare simple.

df. débrir de Senlosture.

10. petite janbe didele

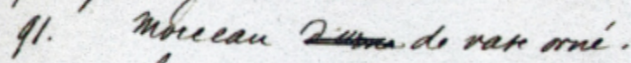

12. has sne'.

13. wat imple Contenent dived nomeease.

94. Tete snie ceulptié el peante.

gr. morceang de thatuet te (Mide of masies)

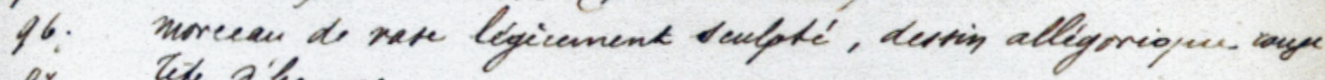

af. Tite athoume.

11. Tete formant fied avee taule interiecue.

19. nenthe rné

iro. Lete sominel.

101. lot dimple.

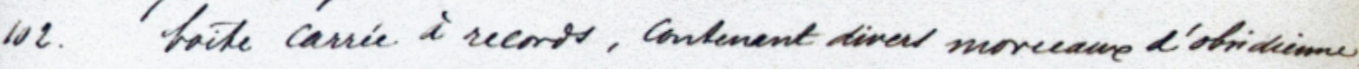

103. vare une

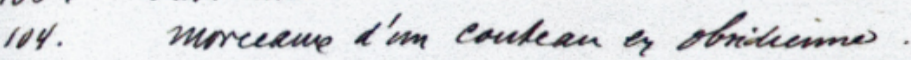

105. Mre sudimentaire.

106. to revé.

10. Shachette viense recte.

101. it il

110. Coutean de Sacrificatane. Dilep riolet.

III. Hete de lance en dilep treis fin

III. Jia formant tete avee balule inticain.

13. Th thethe fience reste.

114. Hone snel d'un animal.

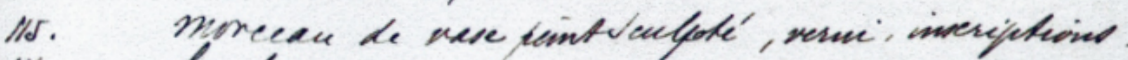

116. hachethe viene weits.

117. hachatte /puive it.

119. Tole arnée peinte en nois

II). Hole formant pied de plat avee boule intévecines

120. tó d'animal.

12. morcean de save.

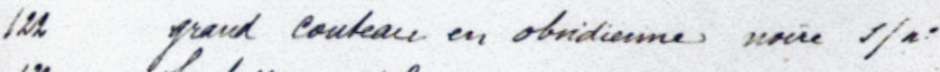

123. hechette en tilere.

12t. petite tete d'animal.

iff. tete a'animal.

12.: nerveau de sere aneé

-28. frod de merque.

ke. Hete formant jied aved boule. 


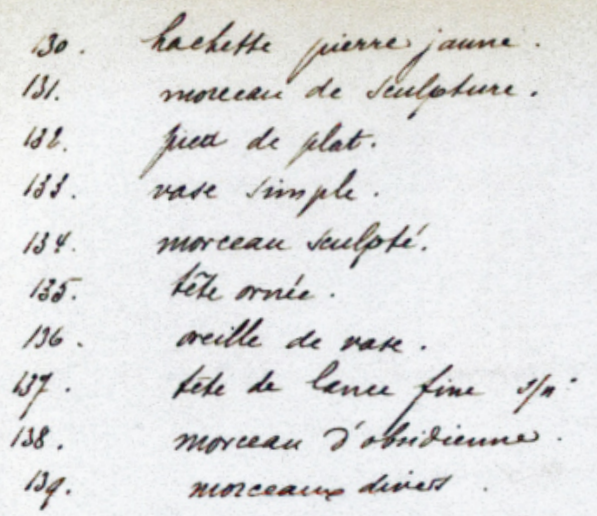




\section{Letter from Professor Adolf De Ceuleneer}

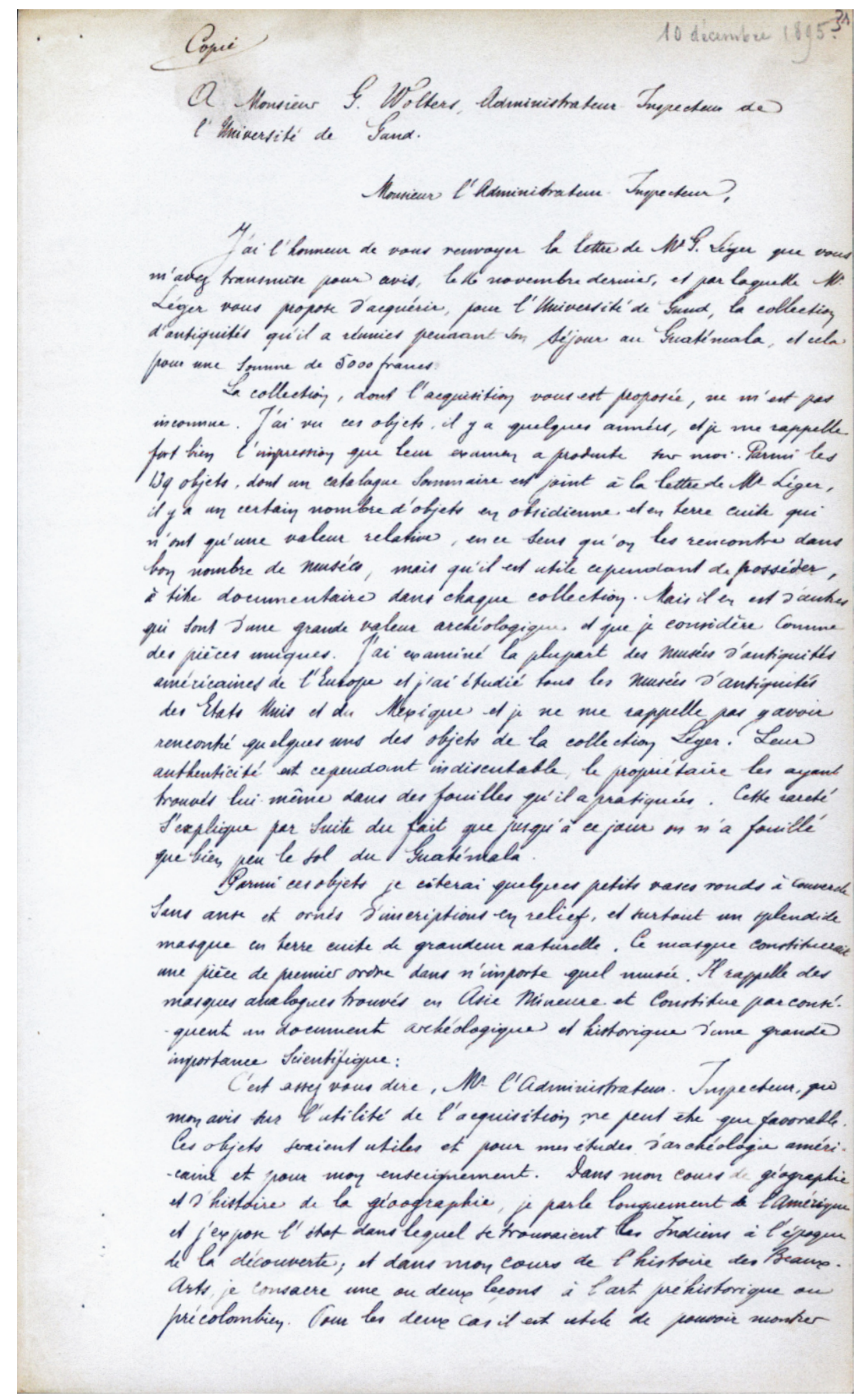


ame eleines quelpues olyets qui puirsent leus donner des rdéer de las

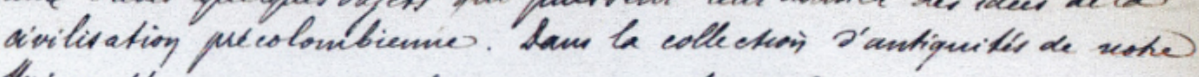

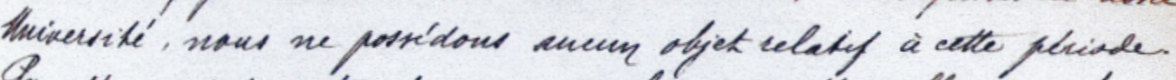
Sernetty moi du verte de vaus cappeles que cethe edlectring formete

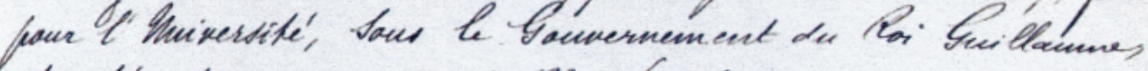
ect resté thationnare de quis 1830. Tes dyetr a equis dequir cette.

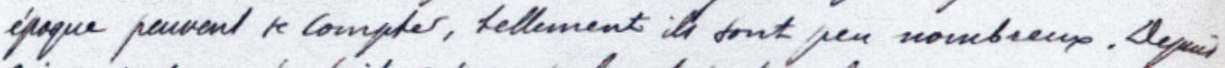
quime ans on n'a fait qu'un seul achat de quelquer yetiter antipuideis égyptinner, et cella paur le minime trmme de voir ante fraceer. 1. serais curcus de pouvair dévelogper utit a petit ectte edlection

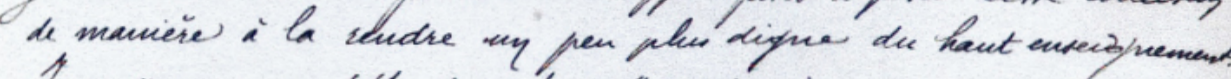

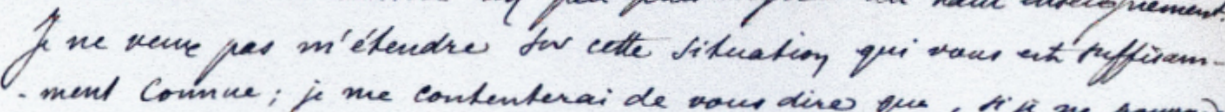

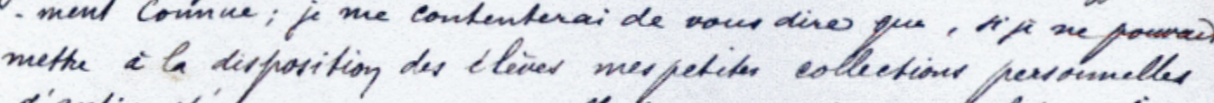
d'antiquitei, ainn que ma edtection de castes et de photapreqtier, It ne terait quasi impossitle de domer un enseignement giagrapha

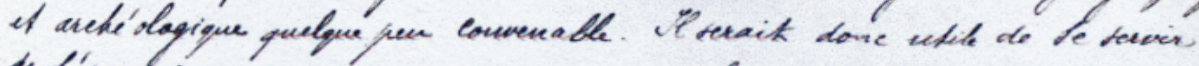

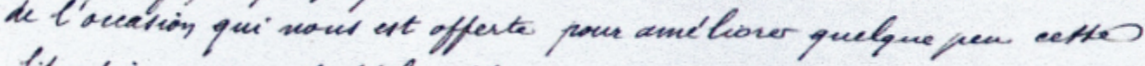
Situation vreiment déplorable.

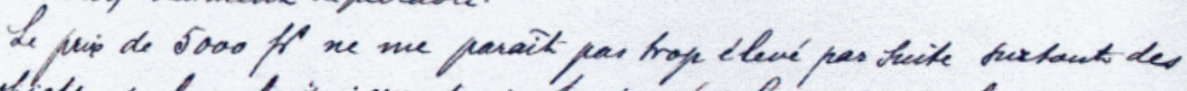

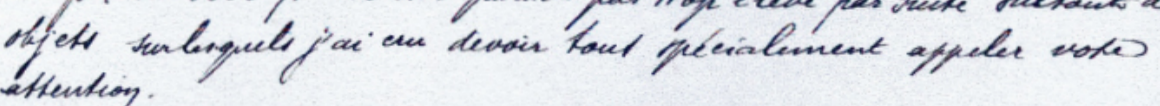

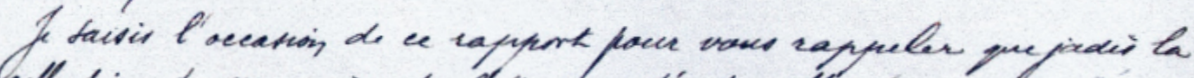

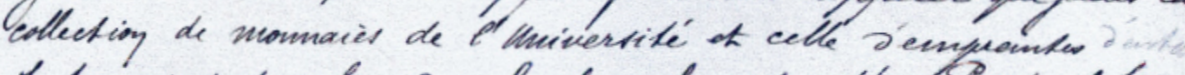
te trausaient dans le mine locel que les antiquités. Pendant les traname faits ì l'anciemne Mniversile', er collections ont ité tranfirces à la Bibliothique in elles ne dauraient tervir à $l$ 'enseignement. J'ai l'homenr de vaus lemander que eer

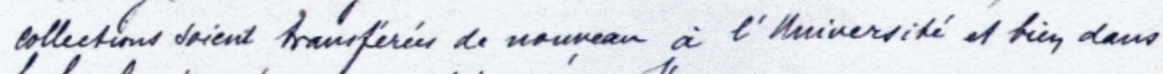

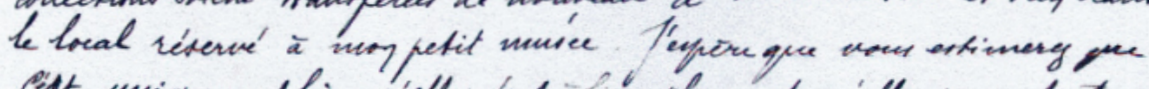
rest uniqument li qu'elles tont à lien place et yp elles peurent the de quelque uttite'.

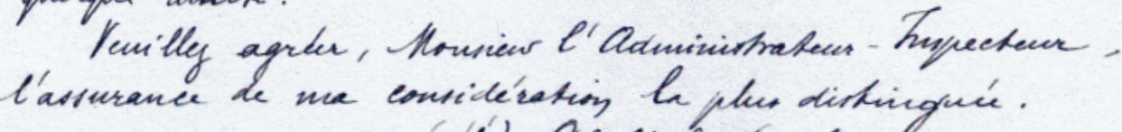

fand, le 10 décuntre 1895.

$$
\text { (vi) Aroly de Cenlenest. }
$$




\title{
FOUILLE DE DEUX TUMULI A CHI-CHEN, GUATÉMALA (AMÉRIQUE CENTRALE)'
}

\author{
Par Jos MAERTENS de NOORDHOUT \\ Membre de la Société Préhistorique de France \\ Conservateur du Musée d'Antiquités de l'Université de Gand
}

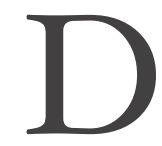

epuis la réunion du congrès des Américanistes, tenu à Bruxelles en I879, aucune manifestation en vue de l'avancement des sciences préhistoriques et protohistoriques des pays de l'Amérique Centrale et de l'Amérique du Sud ne s'était produite. Après la guerre I9I4-I8, nous voyons se former à Bruxelles un noyau d'amateurs et de propagandistes en vue de faire revivre ces études momentanément abandonnées.

L'un des plus dévoués à cette renaissance fut M. Harry Hirtzel, à qui nous devons le catalogue de la nouvelle section d'antiquités précolombiennes des musées Royaux du Cinquantenaire à Bruxelles. ${ }^{2}$

A l'occasion de l'inauguration de la Section Précolombienne, il fut organisé une exposition où la participation du Musée des Antiquités de l'Université de Gand mit en valeur son inestimable collection d'objets recueillis par M. Léger, ancien Consul de Belgique au Guatémala.

Depuis lors, notre participation fut encore sollicitée et tout dernièrement nous prîmes part, à Paris, à l'exposition des Arts anciens de l'Amérique organisée de mai à juin 1928 au Palais du Louvre-Pavillon de Marsan. ${ }^{3}$

Les nombreuses sollicitations qui nous parviennent prouvent à l'évidence la valeur de notre collection. Elle a le mérite d'être unique et l'Université peut, à bon droit, s'en orgueillir.

Pas un Musée d'Europe, ni même celui de New-York dont j'ai visité le merveilleux ensemble, ne possède une collection de pièces aussi caractéristiques que celle dont je vais vous entretenir ce soir.

En I894, Georges Léger, alors Consul de Belgique à Cobán (Guatémala), de qui nous avons pu acquérir la collection pour le Musée des antiquités de l'Université de Gand, obtint d'un Indien influent la permission de fouiller deux tumuli. Cette autorisation vaut d'être citée, étant donné que, par principe, les indigènes s'opposent formellement à ce que l'on touche aux monuments pouvant renfermer des restes de leurs ancêtres.

Je cède donc la parole à $M$. Léger, qui nous fera part, dans les notes que j’ai pu sauver pendant l'occupation allemande, de la façon dont les objets furent mis au jour. 
" A environ deux heures à cheval dans la direction du Sud de la ville de Cobán, (département de Haut Verapaz), se trouve une hacienda de bétail, appartenant depuis de nombreuses années à la famille Sierra.

Le nom indien de cette hacienda est Chi-Chen, qu'il ne faut pas confondre avec Chichen-Itza.

Au milieu d'une vallée très large, située à plus de 4,00o pieds au-dessus du niveau de la mer, entourés de hauts coniferes et couverts d'berbes sauvages, se trouvent quatre monticules de hauteurs différentes.

Trois d'entre eux sont de forme conique, l'un à base peu étendue, les deux autres à base allongée. Le quatrième affecte une forme toute différente : il a une longueur d'environ 25 mètres et une hauteur maximale de 3 mètres, tandis que les 3 monticules de forme conique ont une hauteur qui varie entre 6 et 9 mètres.

Chose curieuse à remarquer, le plus grand des trois monticules coniques parait être établi sur une base faite de blocs de roche calcaire travaillées à angle droit. Deux seulement de ces monticules, que j'appellerai des Tumuli, ont pu être explorés et ce, encore partiellement.

Le Tumulus qui a fourni les pièces qui à première vue, paraissent les plus intéressantes est le plus petit des monticules coniques. Il a été attaqué le premier parce que sur l'un de ses flancs j'avais aperçu une entrée assez semblable à une entrée de cave avec chambranle et seuil en pierre calcaire taillée à angle droit.

Suivant toute apparence, l'âge de ces Tumuli doit remonter à une époque très lointaine, car les Indiens vivant aux alentours n'avaient pas la moindre idée de ce que pouvaient être ces monticules et de ce qu'ils pouvaient contenir.

De plus, pendant les travaux de recherches, en démolissant le tumulus, j'ai dû en faire extraire prudemment le tronc d'un arbre fruitier nommé "Sapote», qui y avait grandi et dont les racines pénétraient à l'intérieur.

Cet arbre, dont le développement est des plus lents et le bois très dur, est par conséquent très lent aussi à pourrir. Or, il se faisait que ce tronc avait I mètre de diamètre et était pourri...

L'attaque par la porte de cave donna comme résultat la découverte d'un plat en terre cuite brisé en différents morceaux, (plat qui, beureusement, put être reconstitué), de quelques débris, de petites têtes et de pieds de plats en terre cuite. Fe décidai donc d'attaquer le monticule par le sommet en y pratiquant d'abord une tranchée longitudinale du sommet à la base et ensuite, croisant celle-ci par le milieu, une tranchée transversale pratiquée également du sommet jusqu'à la base.

A un mètre de profondeur du sommet, j’us la chance de découvrir un véritable sarcophage dont le fond, les côtés et le couvercle étaient formés par des pierres plates de côtés irréguliers, ne ressemblant à aucune des pierres connues à Chi-Chen ou dans les environs à plusieurs lieues à la ronde. C'était un genre de pierres schisteuses se débitant en feuilles.

Le fond du sarcophage comprenait quatre pierres de dimensions inégales et de côtés irréguliers, posées à même le sol. Les deux côtés et les deux extrémités étaient formés de pierres semblables dont les extrémités les plus 
pointues étaient enfoncées en terre, tandis que le couvercle était fait de pierres plates comme celles du fond, reposant sur les côtés du sarcophage.

C'est par dessous le couvercle du sarcophage qu'ont été trouvées deux des potiches avec têtes ornementées, polychromées et portant des caractères biéroglyphiques.

L'une des deux potiches contenait une matière grisâtre ressemblant à du terreau. En enlevant le contenu, j'y découvris une phalange de doigt bumain et deux fines lames d'obsidienne noire coupantes et très effilées.

A l'intérieur du sarcophage se trouvaient quelques ossements et une boîte crânienne qui, au contact de l'air, tombèrent en poussière.

C'est dans ce sarcophage que fut trouvé le collier en pierres de jade. De toutes les trouvailles, ce fut celle qui offrit le plus d'intérêt. Les autres potiches, statuettes, masques petits et grands et couteaux de silex, ont été trouvés éparpillés dans ce tumulus conique et dans celui de forme allongée. En général les potiches renfermaient des obsidiennes, quelques-unes une phalange de doigt, et toutes, la même matière grise ressemblant à du terreau (peut être des aliments décomposés).

Il est à remarquer que les potiches photographiées comme placées dans des soucoupes, ne devaient pas l'être ainsi. En effet, ces dessous sont des couvercles et toutes les potiches ont été découvertes placées droites dans la terre des Tumuli et fermées par leur couvercle.

Les fouilles ont dî être conduites avec une extrême prudence parce que dès la découverte des premières poteries, je m'étais aperçu que l'bumidité séculaire où elles avaient été avait rendu les terres-cuites tellement friables qu'au moindre toucher les dessins et les couleurs disparaissaient. Il fallut donc, chaque fois qu'une pièce apparaissait, la faire découper dans la terre du Tumulus au moyen d'un couteau et d'un bloc, la laissant entourée d'une couche de terre. Au bout de quelques heures, exposée à l'air et au soleil, la terre se desséchait et tombait d'elle-même, et la potiche reprenait sa fermeté primitive et pouvait être maniée sans risque.

A noter que le grand masque en terre cuite et l'idole de pierre ont été trouvés dans le Tumulus allongé. \”

Ici se termine la description que nous donne M. Léger.

Jos MAERTENS de NOORDHOUT I930

1 - Extrait du Bulletin de la Societé d'Histoire et d 'Archéologie de Gand, 1930. pp. 5-9.

GAND.W. SIFFER, IMPRIMEUR. Place St-Bavon.

2 - J. HARRY-HIRTZEL, Les antiquités Précolombiennes des Musées Royaux du

Cinquantenaire. 1927, Bruxelles.

3 - METRAUXA. et RIVIERE J. Les arts anciens de I'Amérique. Paris, 1928, G. Van Oest, p. 107. 


\section{HIEROGLYPHIC INSCRIPTIONS}

\section{An interpretation by ROGELIO VALENCIA RIVERA ${ }^{1}$}

July 2020

\section{EVUG GE I 00045}

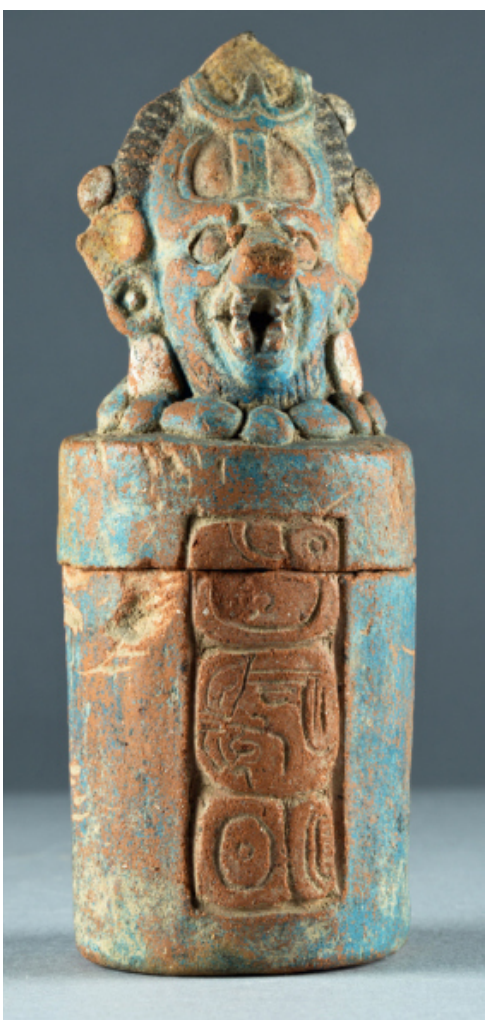

The lids of vessels GE I 00044 and GE I 00045 were shaped into late versions of the head of the Maya god K'awiil.

He is recognizable because of its facial features, the mirror symbol represented on its forehead and the hair at the edges of its head (Valencia 2016).

He usually appears represented with simple ear ornaments and a beaded necklace. This deity is associated with lightning, food abundance and royalty.

The representation on vessel GE I 00045 can be compared with a similar vessel made out of jade mosaic work from Tikal (see Annex 4, page I4I).

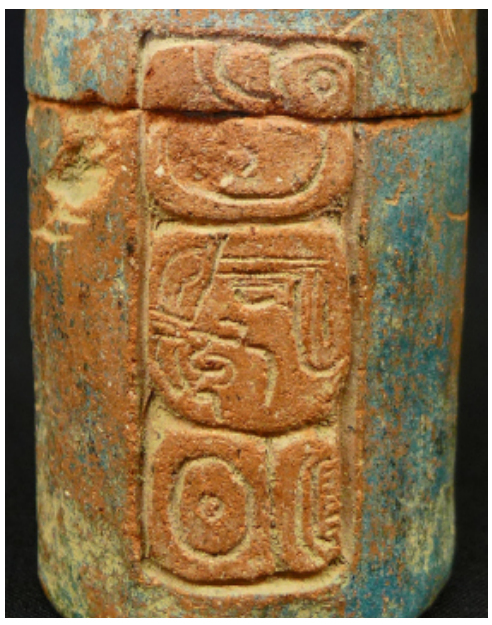

The text on the front could be read as:

lu?-ya?-AJAW PET-ka

... yajaw petka

'... his lord petka',

where petka could be an anthroponym. 

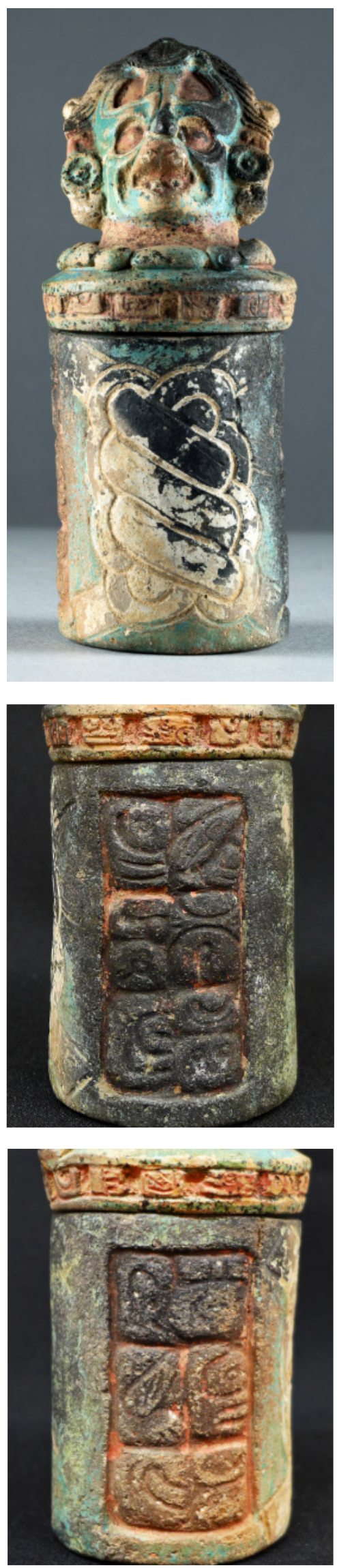

Vessel GE I ooo44 presents another version of god K'awiil. His identification is reinforced by the presence of a mat symbol engraved on the vase; a symbol usually associated with royalty. The text on the rim of the lid is illegible.

The 'glyph'-band seems to be made by mold printing or carving, or both. Probably it was intended as decoration.

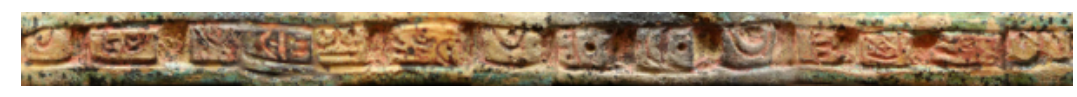

\section{Side A}

The inscription on Side A could be read as:

\section{AL-? u-K'IN-CHAK-? HUL/KAL-mu-bi}

al ... ukinchak... bulmuub/Kalmuub

no translation provided.

The second part of the texts is basically illegible.

\section{Side B}

The inscription on Side B could be read as:

jo-ma-ja ?-AL-?

johmaj ... al $\quad . . \quad$ "It was engraved..."

On the first row of the text the word jobmaj could be read, which is the passive form of the verb jom.

The word jom is translated as 'engrave, groove' (García de León I971:50; Hurley and Ruiz 1986:66).

On the second row, the text continues with a pair of glyphs

that appear on the first row of Side A, but their order is inverted. The last row of this text is illegible. 

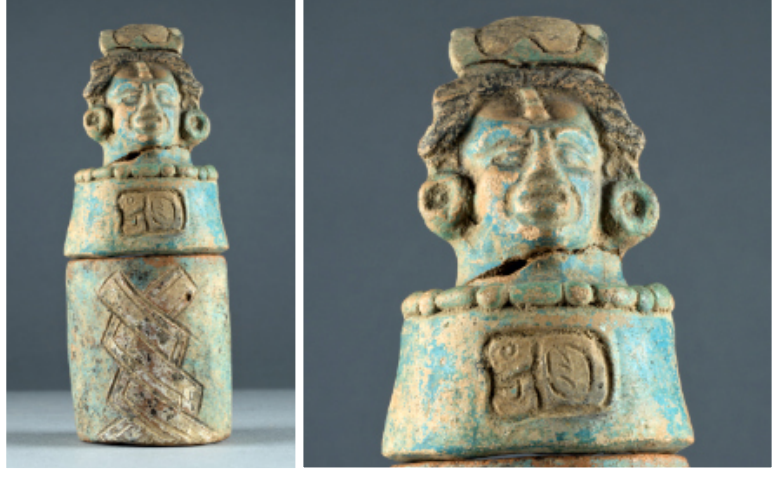

The lid of the vase represents the head of a Maya lord, an identification reinforced by the presence again of the mat symbol on the front of the vase. The text on the lid could be read as: a-ta, at, the word at has two possible meanings, 'to bathe', or 'penis' (García de León I971:39).

\section{EVUG GE I 00040}
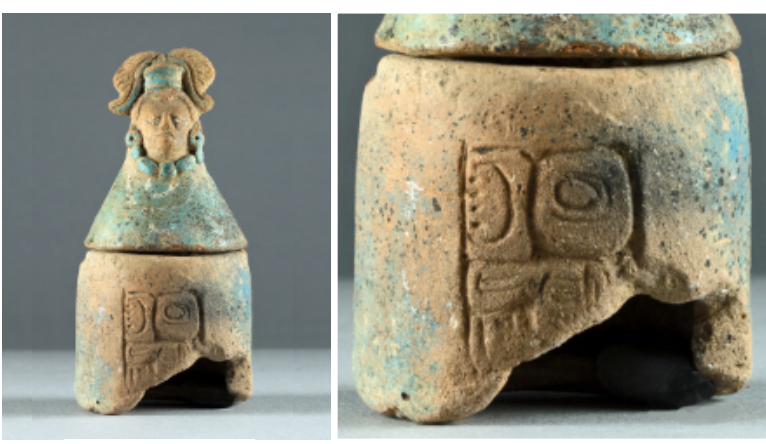

The lid of this vessel seems to represent the head of a noble woman. The base has a text that includes a ja sign but is unreadable.

\section{EVUG GE I 00016}

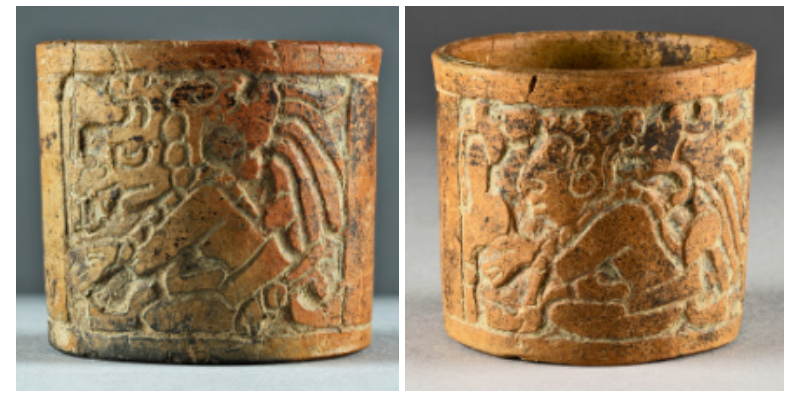

\section{EVUG GE I 00022}
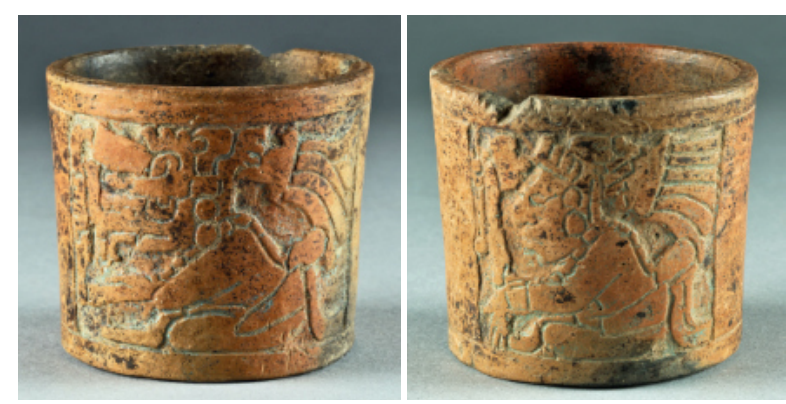

On Registers G.E. I.I6 and G.E. I.22 there is another representation of god K'awiil (on both sides A), represented alongside a Maya ruler (sides B).

In this case K'awiil still preserves the flaming ax on its forehead.

These images of K'awiil are similar to the representation of the same god coming from Zacualpa, Guatemala (Lothrop I936:24).

See Report, page 66, fig. 46 . 


\section{REFERENCES}

GARCÍA DE LEÓN, Antonio, I97I.

Los elementos del tzotzil colonial y moderno. Centro de Estudios Mayas, Cuaderno 7, UNAM, México.

HURLEY, Alfa, and Agustín RUIZ SÁNCHEZ, 1986.

Diccionario tzotzil de San Andrés con variaciones dialectales. Instituto Lingüístico de Verano. México.

LOTHROP, Samuel. K., I936.

Zacualpa: A Study of Ancient Quiché Artifacts. Carnegie Institution of Washington, Publication 472. Washington D.C.

VALENCIA RIVERA, Rogelio, 2016.

El rayo, la abundancia y la realeza. Análisis de la naturaleza del dios K'awiil en la cultura y la religión mayas. $\mathrm{PhD}$ Dissertation. Universidad Complutense de Madrid. 


\section{REGISTRATION NUMBERS}

AND MEASUREMENTS OF THE ARTIFACTS

EVUG (Etnografische Verzamelingen van de Universiteit Gent)

All photographs by Tom Debruyne and Julia Montoya.

Figure 5. (d) EVUG GE I ooroo (4.I x I 4 cm).

Figure 28. EVUG GE I $00099(9.6 \times 29.7 \mathrm{~cm})$.

Figure 29. I. EVUG GE I $00068(5.3 \times 5.6 \mathrm{~cm})$.

2. EVUG GE I 00069 (4.I $\times 5.7 \mathrm{~cm})$.

3. EVUG GE I $00072(4.5 \times 6.4 \mathrm{~cm})$.

4. EVUG GE I 0007I ( $4 \times 4 \mathrm{~cm})$.

5. EVUG GE I $00073(4.1 \times 4.7 \mathrm{~cm})$.

6. EVUG GE I $00070(4.5 \times 5.4 \mathrm{~cm})$.

Figure 30. (a) EVUG GE I $00044(4.4 \times 5.5 \mathrm{~cm})$.

(b) EVUG GE I ooo $45(\mathrm{I} 3.9 \times 5.4 \mathrm{~cm})$.

Figure 3I. EVUG GE I ooII4 (45/45 pieces, length $63 \mathrm{~cm})$.

Figure 32. EVUG GE I $00039(23.4 \times 23.1 \mathrm{~cm})$.

Figure 33. EVUG GE I $00050(19.7 \times 9.9 \mathrm{~cm})$.

Figure 34. (a) EVUG GE I ooo49 ( 16 x I2 cm).

Figure 36. (a) EVUG GE I 00040 ( $12 \times$ x 6.I cm).

(b) EVUG GE I $00043(15.8 \times 7.9 \mathrm{~cm})$.

Figure 37. (c) EVUG GE I 0004I (I4 X $5.4 \mathrm{~cm}$ ).

(d) EVUG GE I $00046(\mathrm{I} 5.2 \times 5.9 \mathrm{~cm})$.

(e) EVUG GE I ooo42 (I3.8 x $6.2 \mathrm{~cm})$.

Figure 38. EVUG GE I ooor6 $(6.1 \times 7.7 \mathrm{~cm})$.

Figure 39. EVUG GE I ooo9o $(8.5 \times 9.9 \mathrm{~cm})$.

Figure 40. I. EVUG GE I ooio6 (Io.8 $\times 3.6 \mathrm{~cm})$.

2. EVUG GE I ooI $28(7.4 \times 3.2 \mathrm{~cm})$.

3. EVUG GE I ooI $26(6.8 \times 6.3 \mathrm{~cm})$.

4. EVUG GE I ooo87 $(6.2 \times 6.5 \mathrm{~cm})$.

5. EVUG GE I 0005I $(8.9 \times 8.2 \mathrm{~cm})$.

6. EVUG GE I ooo9I $(9.8 \times \mathrm{I} 2 \mathrm{~cm})$.

7. EVUG GE I 00054 (II x $9.9 \mathrm{~cm})$.

8. EVUG GE I ooo55 $(9.3 \times 6,8 \mathrm{~cm})$.

9. EVUG GE I oooor (IO.2 $\times 7.5 \mathrm{~cm})$.

Io. EVUG GE I ooI $24(5.2 \times 9.2 \mathrm{~cm})$.

II. EVUG GE I ooI23 $(6.3 \times 6.5 \mathrm{~cm})$.

I2. EVUG GE I 00056 ( $12.2 \times 7.7 \mathrm{~cm})$.

I3. EVUG GE I $00066(4.4 \times 3.3 \mathrm{~cm})$.

I4. EVUG GE I ooo88 $(5 \times 6.5 \mathrm{~cm})$.

I5. EVUG GE I ooor4 $(7.2 \times 8.5 \mathrm{~cm})+$ lid GE I ooo $36 .(2.6 \times 9.4 \mathrm{~cm})$.

I6. EVUG GE I oooII $(8.3 \times 7 . \mathrm{Icm})+$ lid GE I ooo $37 .(2.5 \times 8.2 \mathrm{~cm})$.

17. EVUG GE I ooor3 $(7.3 \times 8.6 \mathrm{~cm})+$ lid GE I 0oo35. $(2.1 \times 9.8 \mathrm{~cm})$.

I8. EVUG GE I $00033(4.8 \times 3.8 \mathrm{~cm})$.

I9. EVUG GE I $00092(6.8 \times 4.2 \mathrm{~cm})$. 


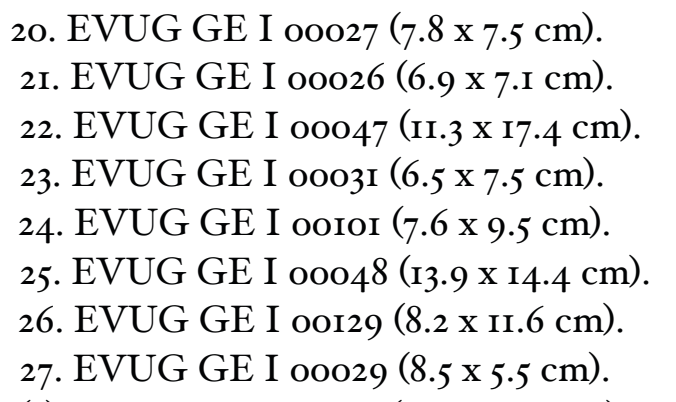

Figure 4I. (a) EVUG GE I 00053 (го.3 $\times 9.4 \mathrm{~cm}$ ).

(b) EVUG GE I ooo6o $(7.6 \times 6 \mathrm{~cm})$.

(c) EVUG GE I $00076(6.2 \times 7.1 \mathrm{~cm})$.

(d) EVUG GE I ooro6 $(9.5 \times 7.8 \mathrm{~cm})$.

(e) EVUG GE I ooo89 $(5.3 \times 3.1 \mathrm{~cm})$.

(f) EVUG GE I ooo84 $(5.2 \times 4.9 \mathrm{~cm})$.

(g) EVUG GE I $00082(3.8 \times 4.2 \mathrm{~cm})$.

(h) EVUG GE I $00077(9.8 \times 10.6 \mathrm{~cm})$.

(i) EVUG GE I $00093(\mathrm{I} 2.2 \times 4 \mathrm{~cm})$.

(j) EVUG GE I oooo7 $(6 \times 4.3 \mathrm{~cm})$.

(k) EVUG GE I $00004(9.7 \times 5.9 \mathrm{~cm})$.

(l) EVUG GE I $00003(9.6 \times 7 \mathrm{~cm})$.

(m) EVUG GE I $00002(9.7 \times 7.2 \mathrm{~cm})$.

Figure 42. Series Silex: see scale EVUG GE 80.I37.I; I38.I; I39.I; I40.I; I42.I; I4I.I; I45.I (2/2).

Figure 43. EVUG GE I ooli8 $(4.2 \times 1.8 \mathrm{~cm})$.

Figure 44. Series Stone: see scale EVUG GE 80.I49.I (II/II); 8o.355.I; 80.379.I; 80.I44.I. EVUG GE I ooII2 (I0.3 x 5.I cm).

Figure 45. Series Obsidian: see scale EVUG 80.I4I [I47].I (2/2); I43.I. (I); I67.I (4I/42); I46.I (6/6); I48.I (3/3).

Figure 46. EVUG GE I $00022(6.9 \times 7.8 \mathrm{~cm})$.

Figure 48. EVUG GE I ooo44 (I $4.4 \times 5.5 \mathrm{~cm})$.

Figure 5o. EVUG GE I ooo44 (lid).

Figure 51. EVUG GE I $00045(13.9 \times 5.4 \mathrm{~cm})$.

Figure 52. (a) EVUG GE I 00078 (7.I x $5.2 \mathrm{~cm})$.

(b)EVUG GE I ooro7 (I5 x $3.8 \mathrm{~cm})$.

Figure 59. (c) EVUG GE I oolo2 $(9.7 \times 4.8 \mathrm{~cm})$.

Figure 6o. EVUG GE I ooor $8(6.6 \times 8.5 \mathrm{~cm})$.

Figure 6I. (a) EVUG GE I $00063(5.8 \times 5.1 \mathrm{~cm})$.

(b) EVUG GE I $00064(5 \times 4.4 \mathrm{~cm})$.

(c) EVUG GE I ooo42 (lid).

Figure 63. EVUG GE I ooo62 $(6.7 \times 6.4 \mathrm{~cm})$.

Figure 66. (b) EVUG GE I 0004I (I $4 \times 5.4 \mathrm{~cm})$.

Figure 67. (a) EVUG GE I ooII4 (45/45 pieces).

Figure 69. (b) EVUG GE I ooo43 (lid).

Figure 70. EVUG GE I oorr6 $(5 \times 4.3 \times 1.8 \mathrm{~cm})$. 


\section{Annex 4 \\ MAYA COLLECTIONS}

\section{GUM}

Ghent University Museum

\section{LACMA}

Los Angeles County Museum of Art

\section{FRM}

Fundación la Ruta Maya Guatemala

\section{FUNBA}

Fundación Nacional para las Bellas

Artes y la Cultura de Guatemala

\section{MAS}

Museum aan de Stroom, Antwerpen / Collection City Antwerp / Ministry of the Flemish Community

\section{MUNAE}

Museo Nacional de Arqueología y

Etnología de Guatemala 


\section{ANNEX 4}

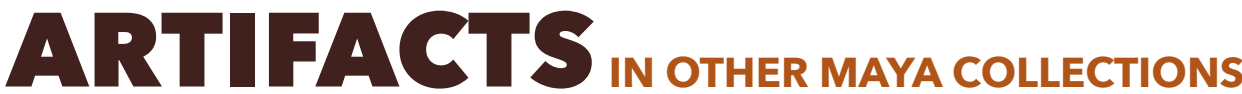 RESEMBLING PIECES FROM CHICH'EN}

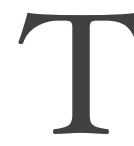

he body of artifacts from excavations in Alta Verapaz is very dispersed and for most pieces their provenance is not known. In order to locate artifacts that show stylistic similarities with those from Chich'en, we visited, in 2017, the collections on display at the Museo Nacional de Arqueología y Etnología (MUNAE) and the Popol Vuh Museum. In addition, we visited the collections of the Fundación Nacional para las Bellas Artes y la Cultura (FUNBA) and the Fundación La Ruta Maya (FRM). Special attention was paid to the collection of this last institution, which, for several years, has been in charge of the conservation and study of the vast collection of the former Museo El Príncipe Maya, a private museum in Cobán. In addition, extensive collections of photographs of Mayan artifacts available in literature and on the Internet were consulted (e.g. FAMSI, The Maya Vase Database and The pre-Columbian Portfolio created by Justin Kerr).

A few pieces similar to the lidded vessels with effigy heads from Chich'en were found. Two of them belong to the FUNBA and the FRM collections. Furthermore, we could localize a series of io lidded vessels (restored), which belonged to a private collection in the United States and are currently kept at the Los Angeles County Museum of Art (LACMA). Unfortunately, the provenance of these objects is not known. Finally, we mention an extraordinary jadeite mosaic vessel with an effigy-head, currently kept at the MAS Museum in the city of Antwerpen. It belonged to the former Janssen-Arts collection of pre-Columbian art. This vessel dates from the Late Classic period (60o-8oo AD) and is remarkably similar to those vessels found in royal burials 116 and 196 at Tikal (see Hellmuth 1967:177-178; Le Fort 2005:III).

A series of 6 ceramic masks on display at the MUNAE deserves special mention. They belonged to the former Dieseldorff collection. The masks come from Alta Verapaz and date from the Postclassic period.

In this annex, we present the aforementioned artifacts. Probably, they come from sites in Alta Verapaz or its surroundings (with exception of the jade mosaic vessel) and had the same function as burial offerings.

This research needs to be continued. 


\section{GUM}

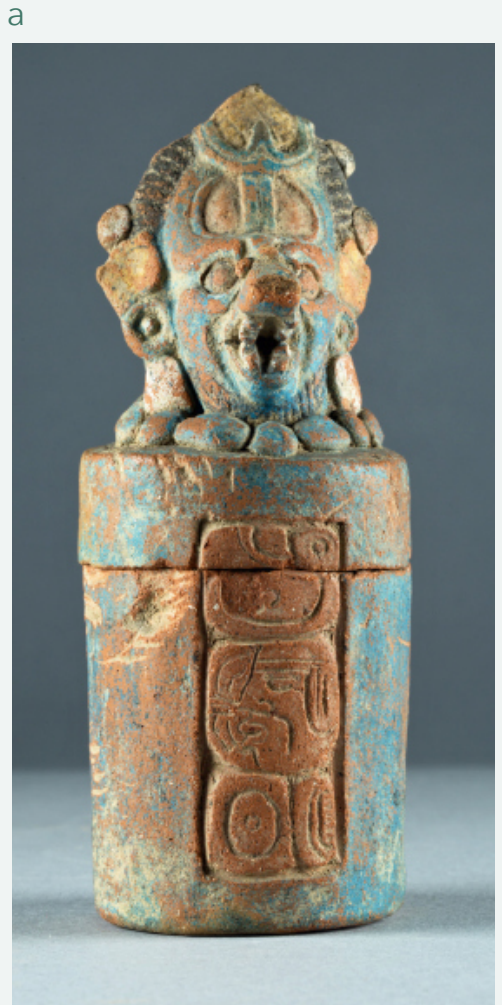

EVUG GE I 00045

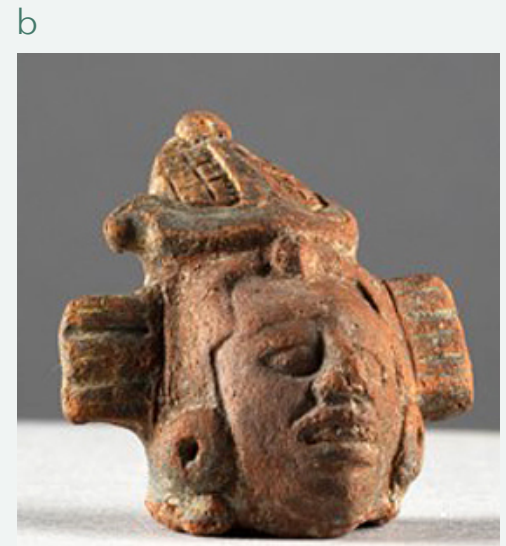

EVUG GE I 00064

\section{LACMA}
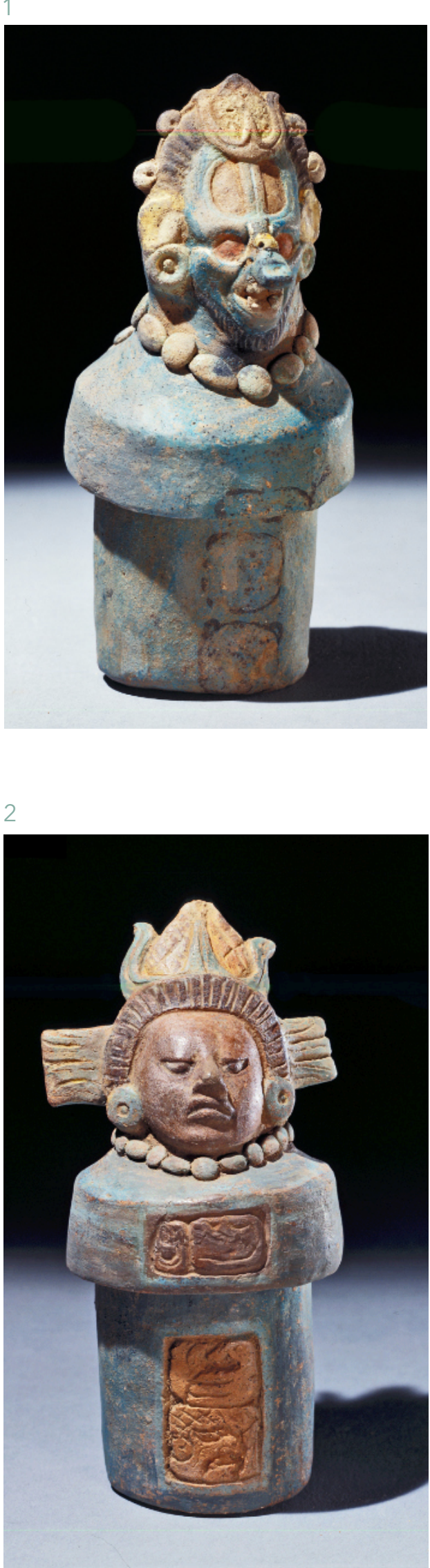


\section{GUM}

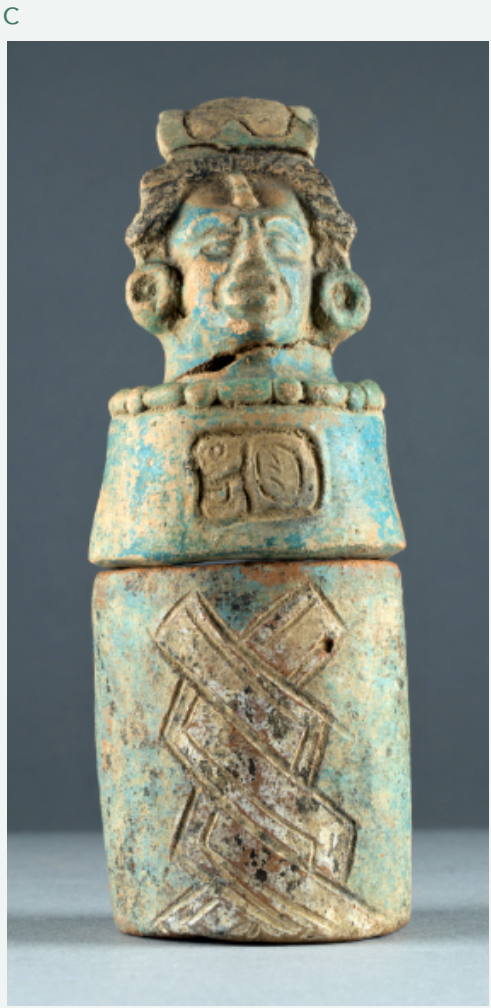

EVUG GE I 00046

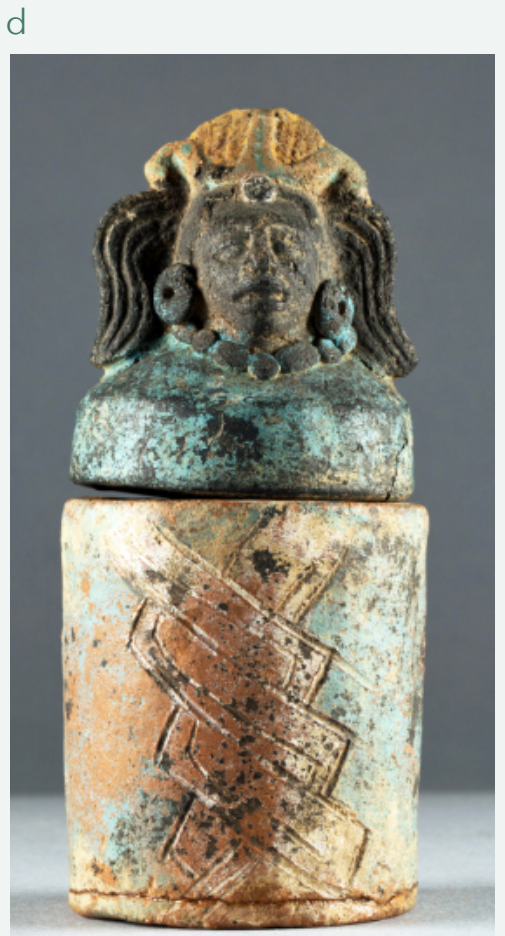

EVUG GE I 00042

\section{LACMA}
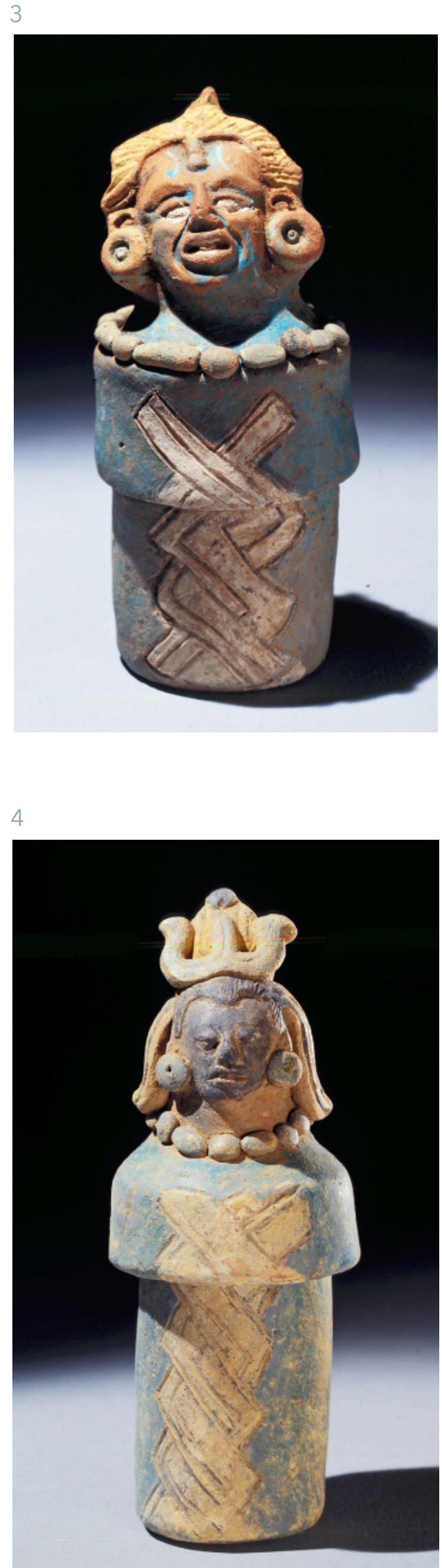


\section{GUM}

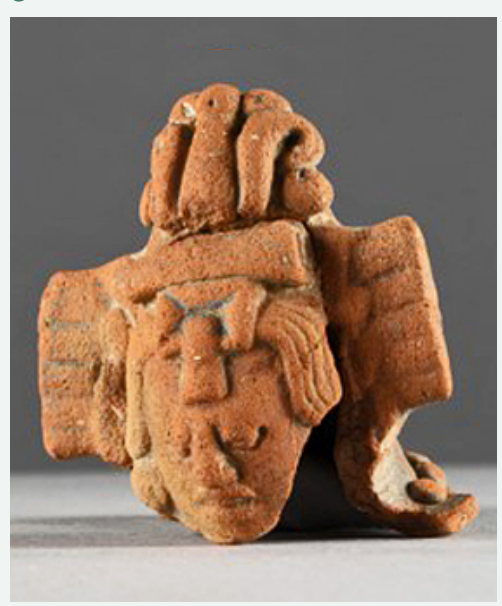

EVUG GE I 00063

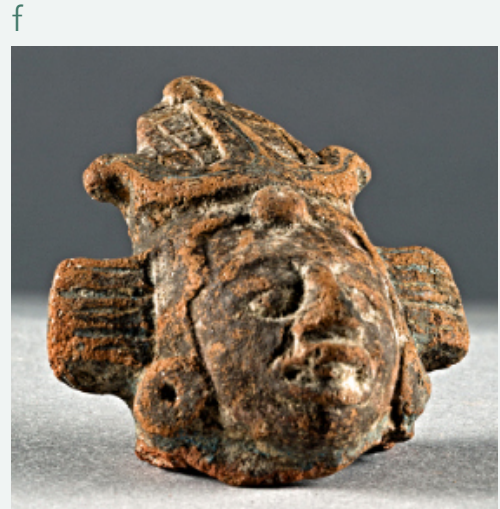

EVUG GE I 00065

\section{LACMA}
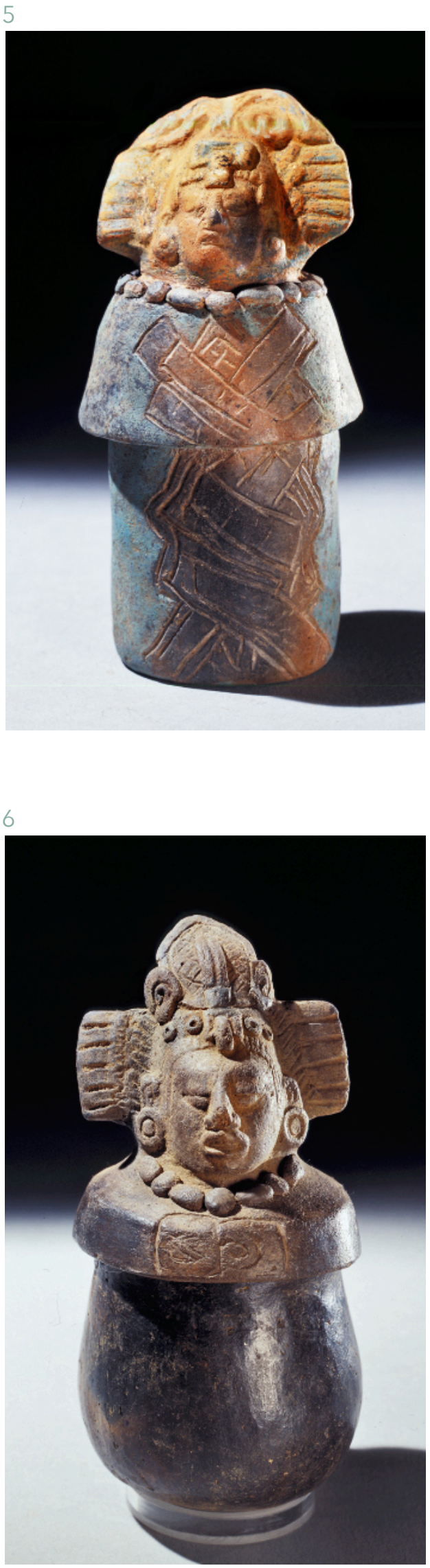


\section{GUM}

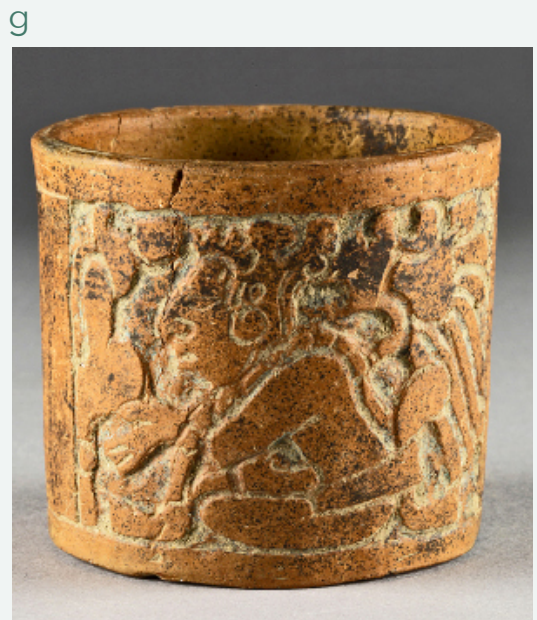

EVUG GE I 00016

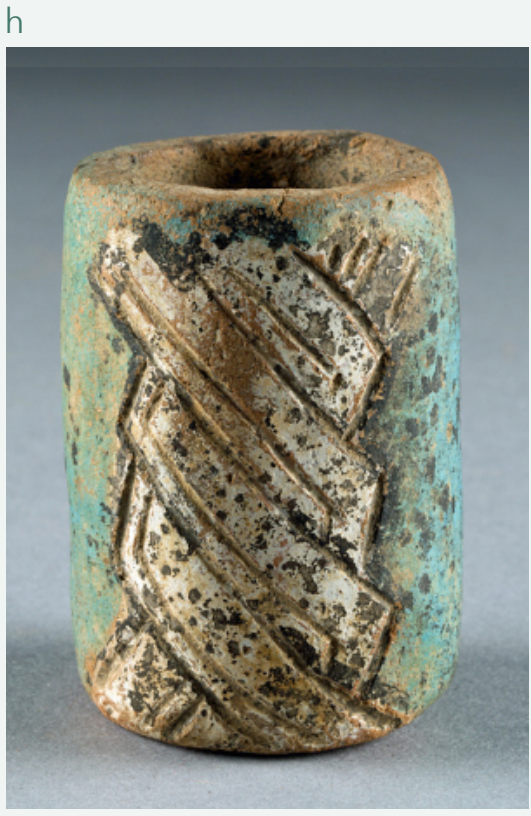

EVUG GE I 00032

\section{LACMA}

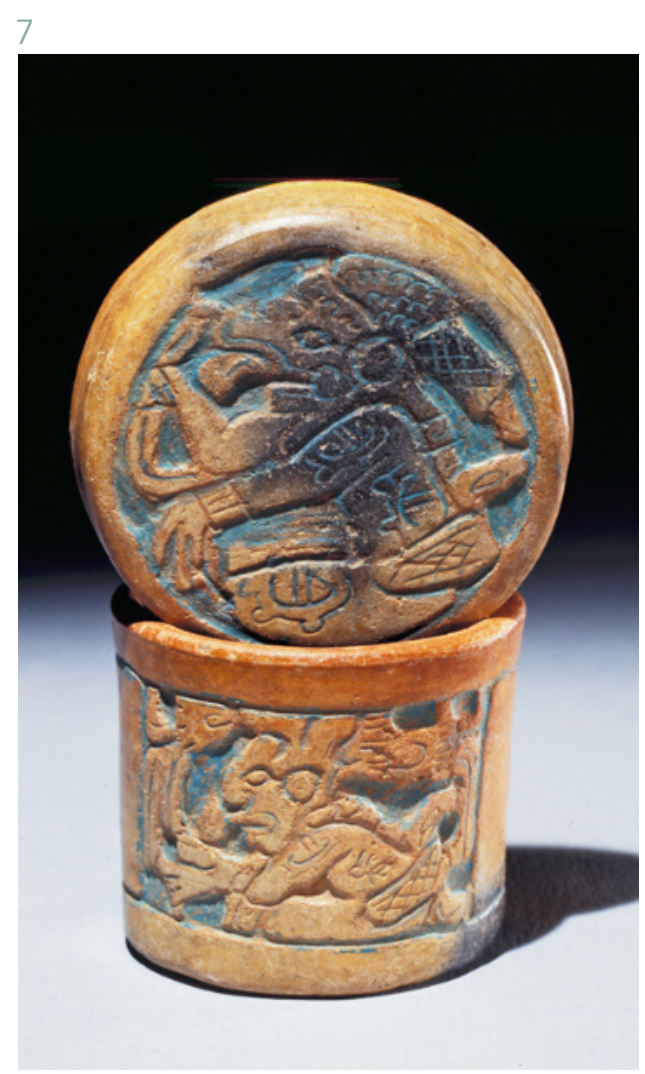

8

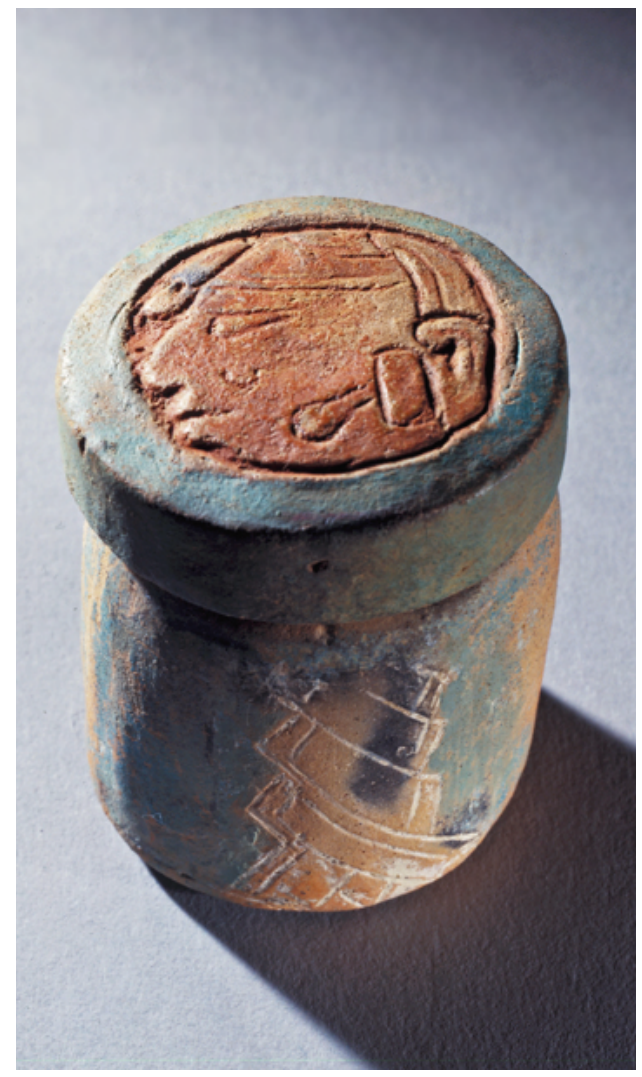




\section{LACMA}
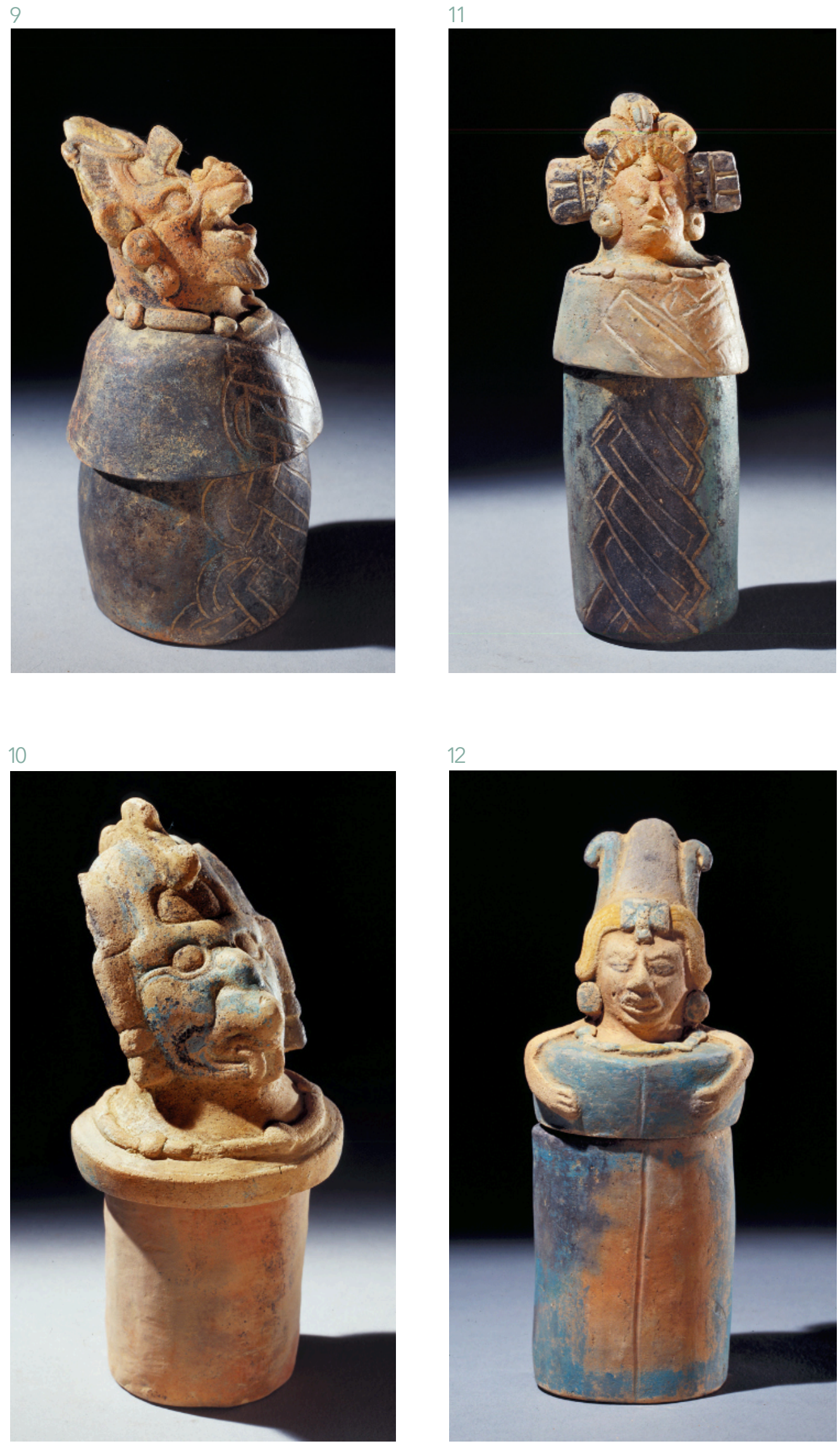


\section{GUM}

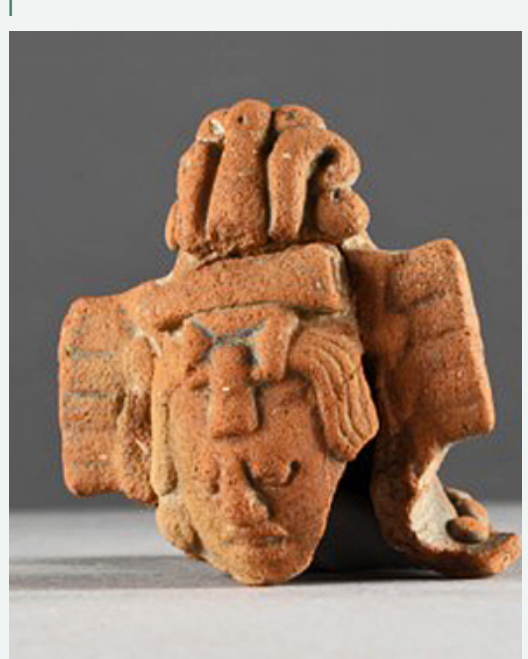

EVUG GE I 00063

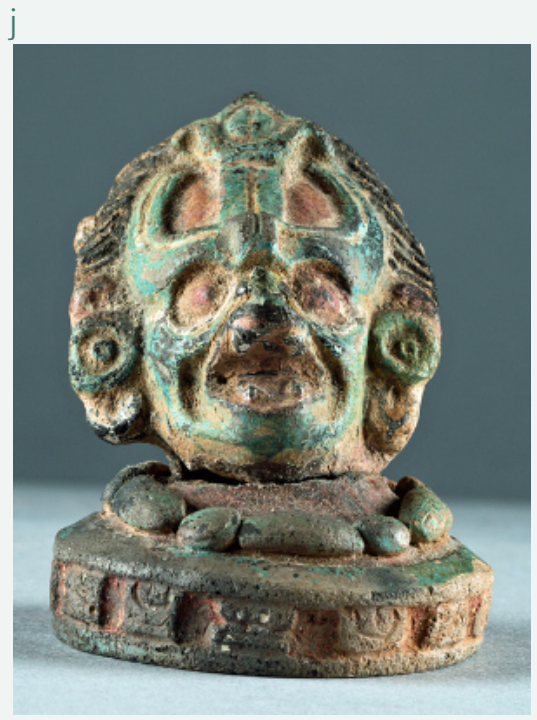

EVUG GE I 00105

\section{FRM}
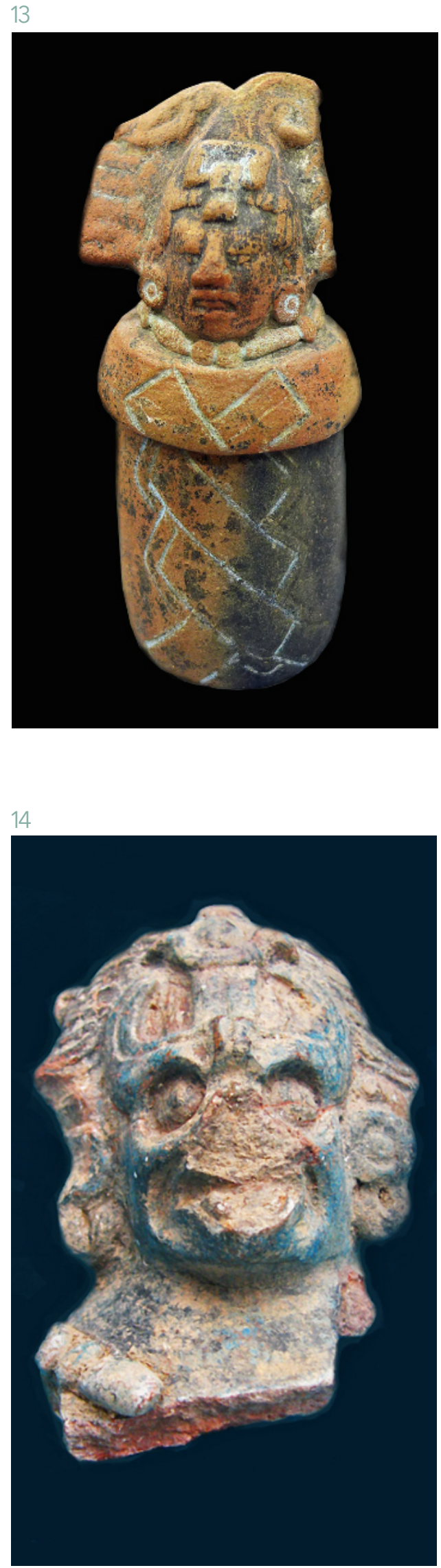


\section{GUM}

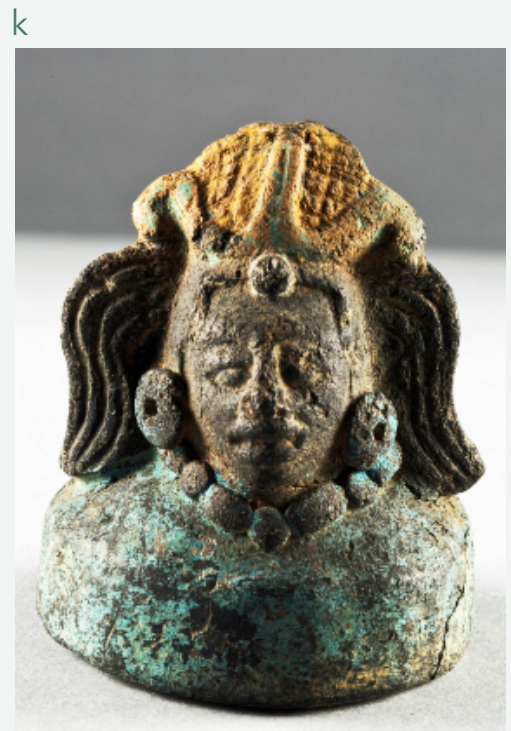

EVUG GE I 00042

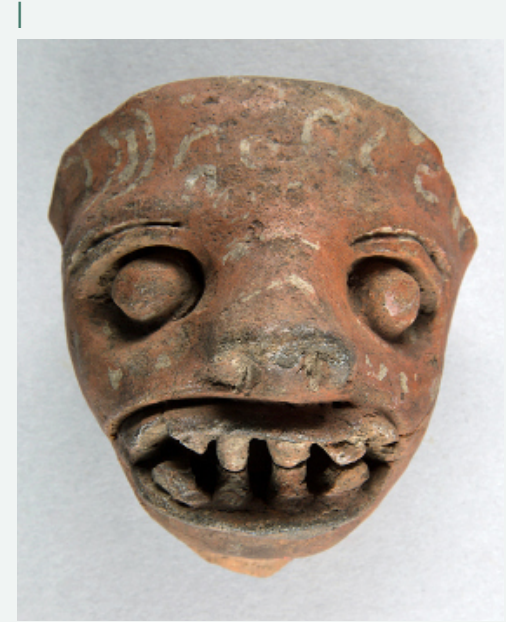

EVUG GE I 00104

\section{FUNBA}
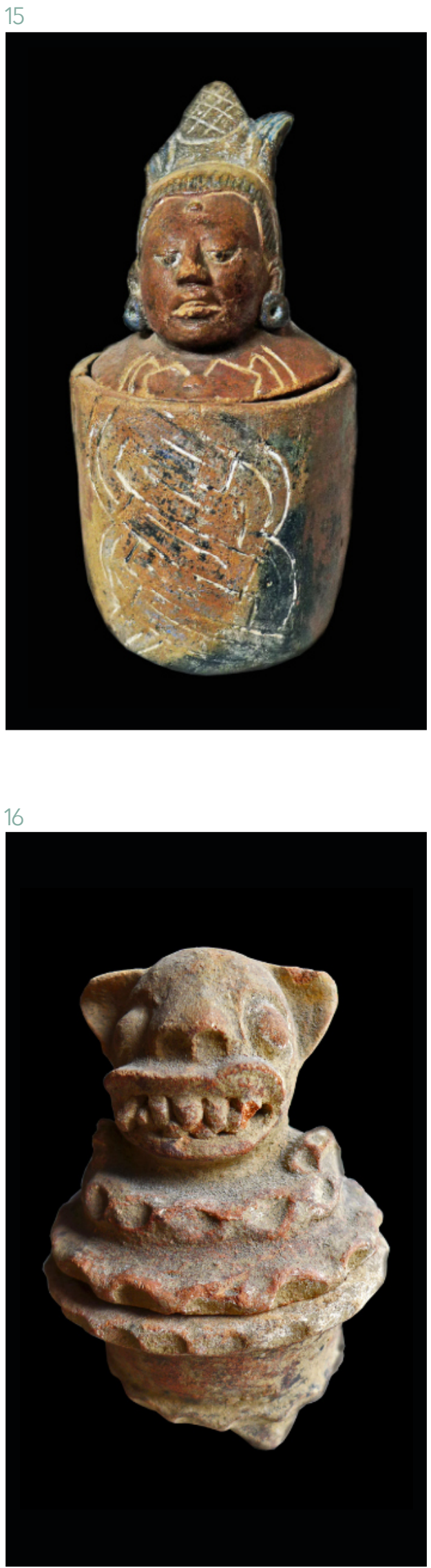


\section{GUM}

m

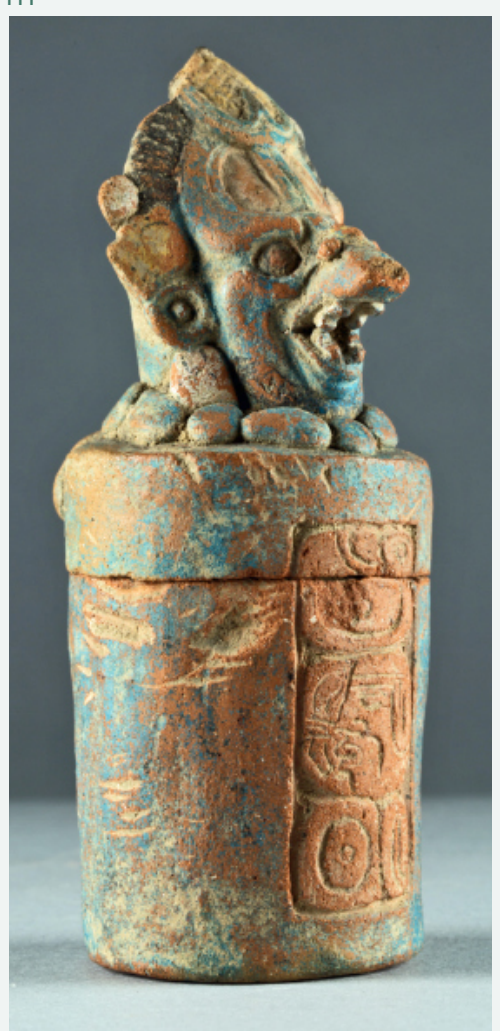

EVUG GE I 00045
MAS

17
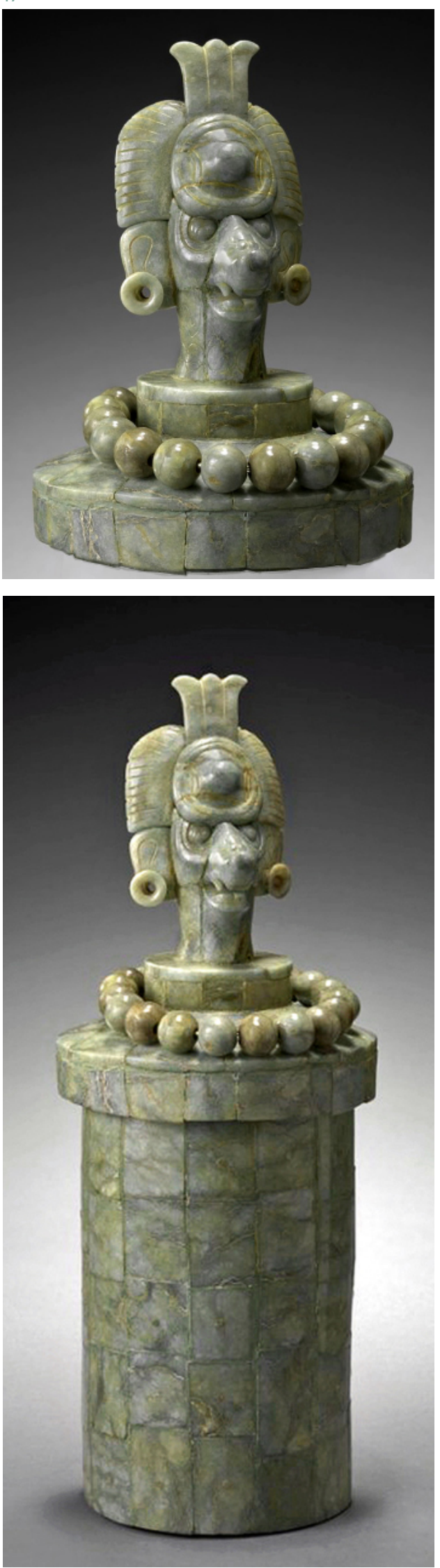


\section{GUM}

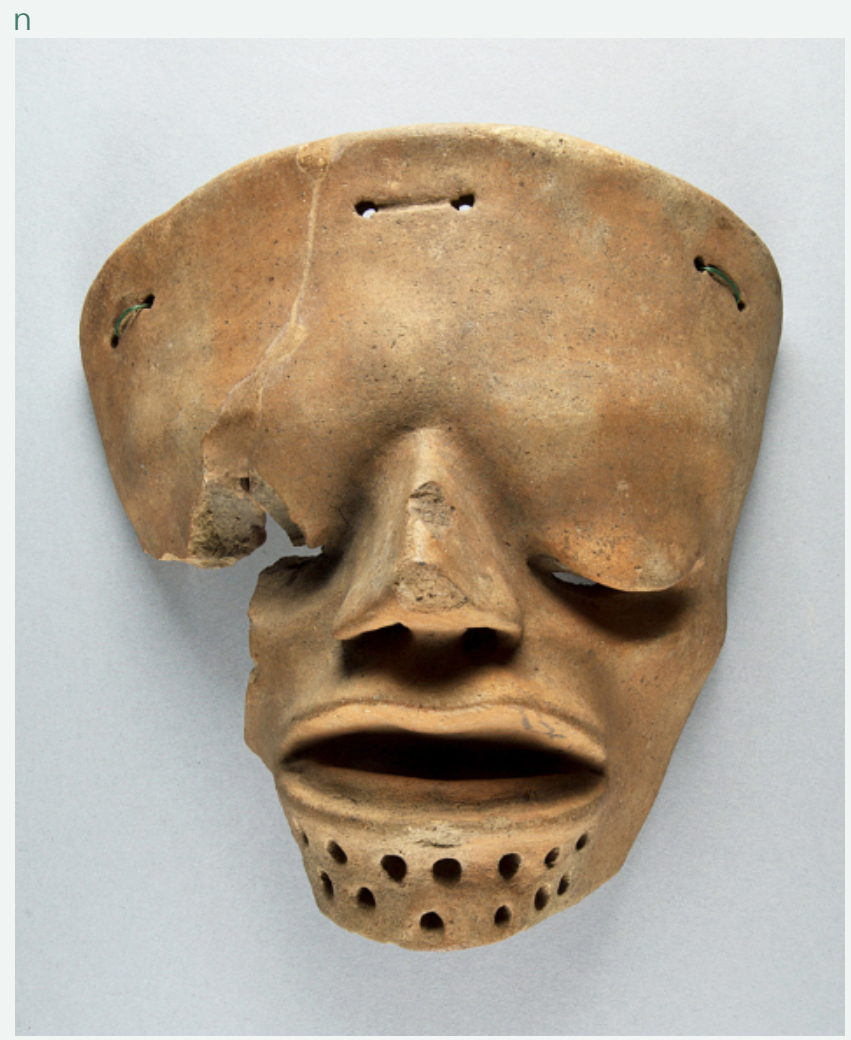

EVUG GE I 00039 


\section{MUNAE}

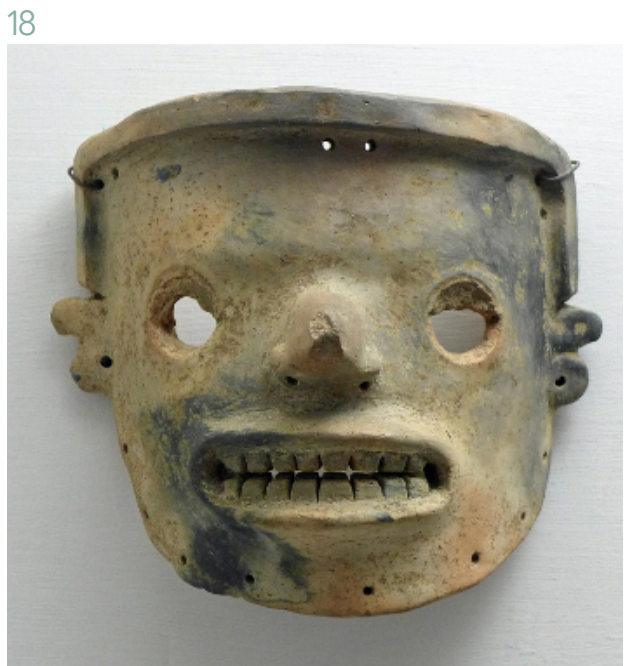

19

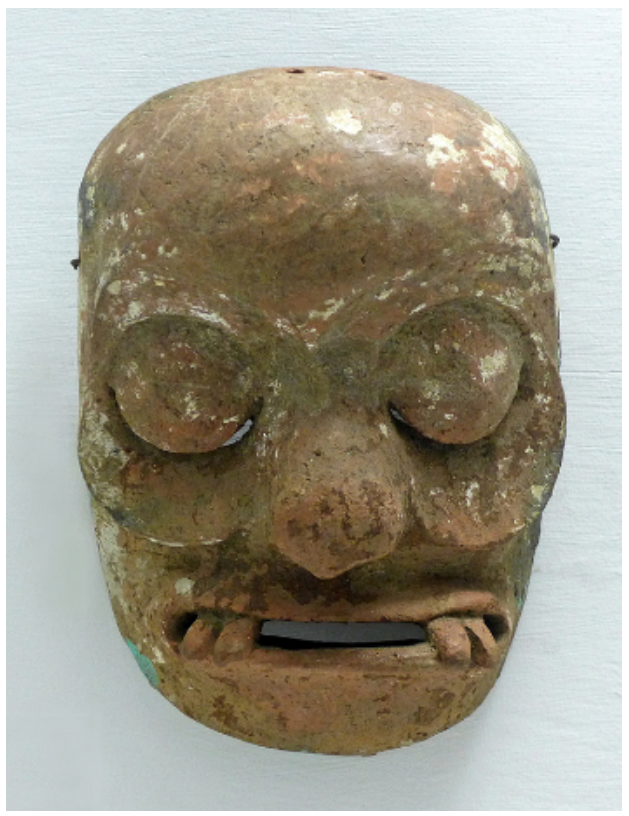

20

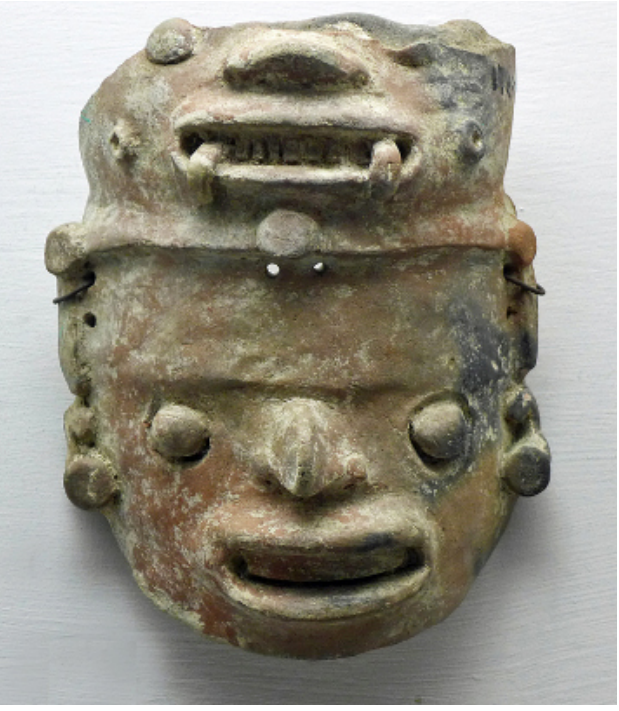

21

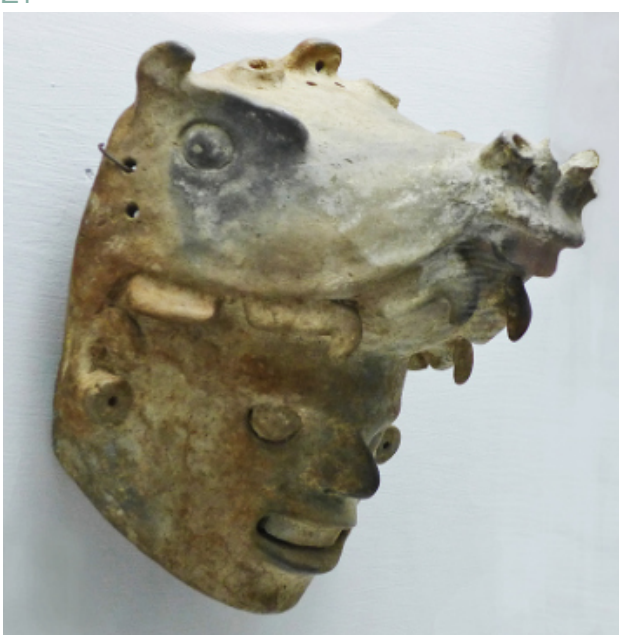

22

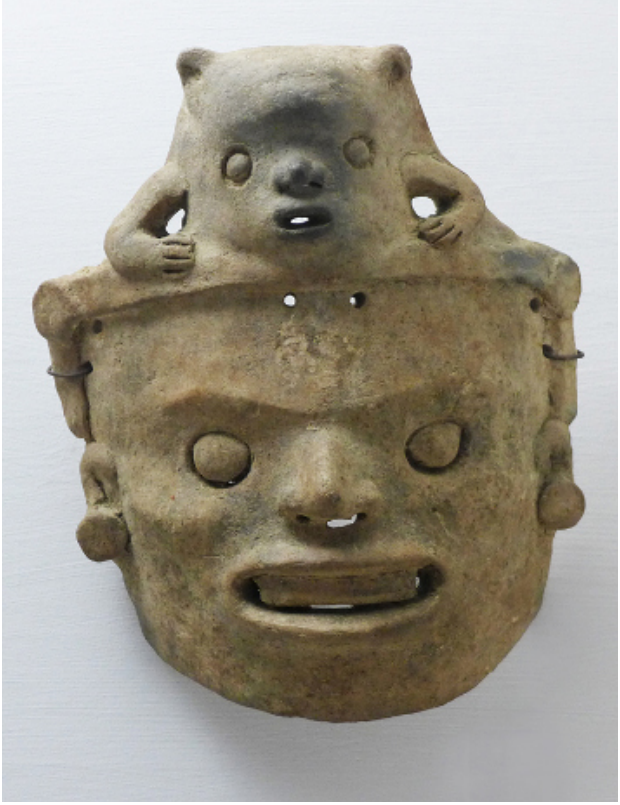

23

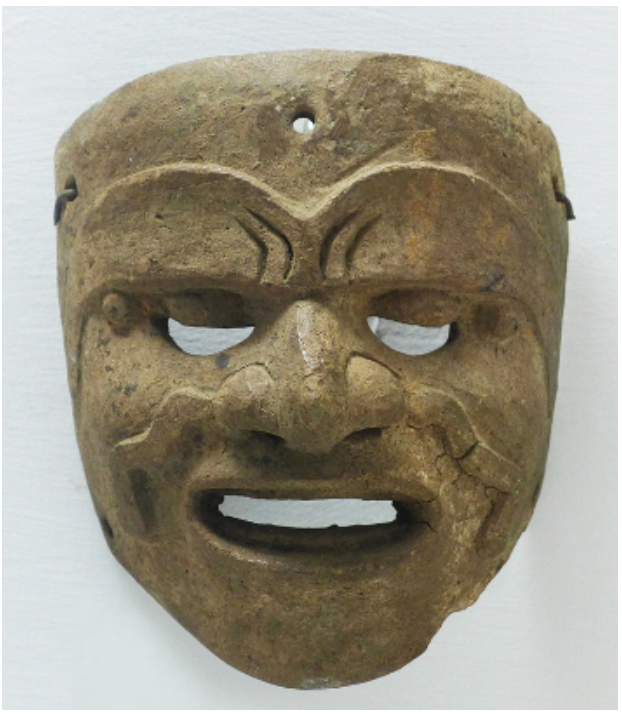


GUM (Ghent University Museum):

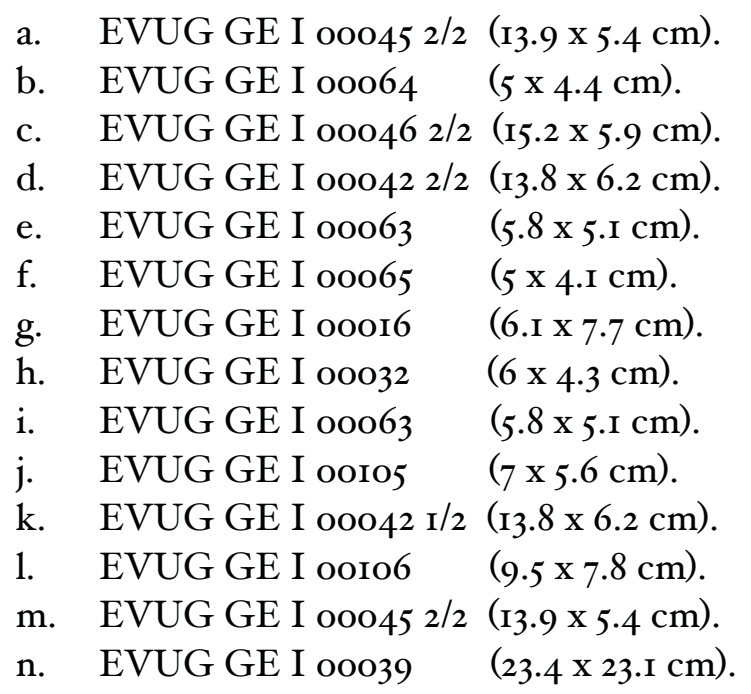

EVUG (Etnografische Verzamelingen van de Universiteit Gent) Photographs: Tom Debruyne and Julia Montoya.

LACMA, Los Angeles County Museum of Art:

I. M.20I0.II5.IOII.6a-b (PHPCoo2_K7208) (I4.7 x 7.I x $7.6 \mathrm{~cm})$.

2. M.2oio.II5.IoIr.3a-b (PHPCoo2_K 7205) (I4.7 x 7.6 x 5.I cm).

3. M.2oio.II5.IOI2.I. (PHPCoO2_K7284) (I2.7 x 5.8 x $5.8 \mathrm{~cm})$.

4. M.20Io.II5.IoIr.9a-b (PHPCoo2_K 72II) (I2.7 X 5.I x $4.5 \mathrm{~cm})$.

5. M.20io.II5.IoII.7a-b (PHPCoo2_K 7209) (I2.7 x $6.4 \times 4.5 \mathrm{~cm})$.

6. M.2oio.II5.IoII.4a-b (PHPCoo2_K 7206) (15.2 x $8.9 \times 9.7 \mathrm{~cm})$.

7. M.20I0.II5.IOI2.2 (PHPCoO2_K7283) (7.I x $6.4 \times 6.4 \mathrm{~cm})$.

8. M.20I0.II5.IoI2.3 (PHPCoo2_K 7282) (7.I x $6.4 \times 6.4 \mathrm{~cm})$.

9. M.20io.II5.Iori.Ia-b (PHPCoo2_K 7203) (I6.5 x $8.4 \times 8.9 \mathrm{~cm})$.

Iо. M.20I0.II5.IOII.2a-b (PHPCoO2_K7204) (I5.2 x 7.I x $6.4 \mathrm{~cm})$.

II. M.20Io.II5.IoII.8a-b (PHPCoo2_K72IO) (I2.7 x 5.I x $4.6 \mathrm{~cm})$.

I2. M.2010.II5.IOII.5a-b (PHPCoo2_K7207) (I5.2 x 6.4 × 6.4 cm).

Photographs: Justin Kerr, Justin Kerr Maya Vase Archive [PHPCooz_K-numbers]. Courtesy Dumbarton Oaks, Trustees for Harvard University, Washington D.C. and LACMA. 


\title{
FRM, Fundación La Ruta Maya, Guatemala:
}

\author{
I3. RM I.2.I44.I $425 \quad(8.5 \times 4.2 \mathrm{~cm})$. \\ I4. $\mathrm{RM}$ I6.2.5.1085 $(4.9 \times 3.5 \mathrm{~cm})$.
}

Photographs: Courtesy FRM.

\section{FUNBA, Fundación Nacional para las Bellas Artes y la Cultura de Guatemala:}

15. FUNBA registration number is not known $($ I0.5 $\times 5.7 \mathrm{~cm})$.

I6. FUNBA registration number is not known (II.7 $\times 8.3 \mathrm{~cm}$ ).

Photographs: by the author, authorized by FUNBA.

\section{MAS, Museum aan de Stroom, Antwerpen / Collection City Antwerp - Ministry of the Flemish Community:}

I7. MAS.IB.2010.0I7.08I.I-2. (39 X I5 cm).

Photographs: Hugo Maertens, courtesy MAS.

MUNAE, Museo Nacional de Arqueología y Etnología, Guatemala:

I8. MUNAE-5802, provenance San Cristóbal Verapaz.

I9. MUNAE-5803, provenance Cobán.

20. MUNAE-7023, provenance unknown.

2I. MUNAE-587I, provenance unknown.

22. MUNAE-580, provenance Cobán.

23. MUNAE-5804, provenance Cobán.

Measurements not known.

Photographs: by the author. 


\section{ILLUSTRATION CREDITS}

The photographers and the sources of visual material are as follows. Every effort has been made to supply complete and correct credits; if there are errors or omissions, please contact the author so that corrections can be made.

Abbreviations:

FRM (Fundación La Ruta Maya, Guatemala).

LACMA (Los Angeles County Museum of Art) / www.ancientamericas.org

Fig.1. Map by the author.

Figs. 2, 3, 4, 7a-b, 9,13,16,17,18a-b, 20c, 21a-e, 22, 23, 28, 31, 52b, 59c, 65 a.

Photos by J. Montoya.

Pages 22, 38, 39, 61a-c. Photos by J. Montoya.

Figs. 5d, 29 (1-6), 30a-b, 32, 33, 34a, 36a-b, 37c-e, 38a-b, 39, 40 (1-27), 41a-m, 42, 43, 44, 45, 46, 48a-c, 50a-b, 51 a-e, 52a, 60a-b, 61a-c, 63a-c, 66b, 67a-c, 69b, 70a-c, and pages 95 and 113. Photos by T. Debruyne and J. Montoya.

Table 1. By the author after Arnauld (1986:20, table 1).

Fig. 5a-c. Photos courtesy FRM.

Fig. 6. Map by Francoise Bagot, after Carta Topográfica, Instituto Geográfico

Nacional, Guatemala. From Arnauld (1986:fig.1), courtesy Charlotte Arnauld.

Fig. 8. Map A. L. Smith (1955:fig. 28).

Figs. 10,11,12. Photos Google Earth, adapted by the author.

Fig.14. Map drawing SD-7159 by L. Schele @ David Schele,

courtesy Ancient Americas at LACMA, edited by the author.

Fig.15. Map drawing SD-7159 by L. Schele @ David Schele, courtesy Ancient

Americas at LACMA, edited by the author after Demarest et al. (2014:188, fig.1).

Fig. 19. Map A. L. Smith (1955: fig. 39), adapted by the author.

Fig. 20a-b. Photos by A. L. Smith (1955: fig. 38 e-f).

Fig. 24. Map Karl T. Sapper (1936:map 1) adapted by the author.

Fig. 25. Photo Joseph Florimond, duc de Loubat Collection (Loubat 1899), courtesy Ancient Americas at LACMA.

Fig. 26. Photo by Alfred Percival Maudslay (1898). Available at https://commons.wikimedia.org/wiki/File:A_glimpse_of_Guatemala_155-

People_from_Cobán_1898.png

Fig. 27. Photo by A. Estrada Monroy (1979:161).

Fig. 34b. Photo by H. Hirtzel (1925:669, fig.10).

Fig. 34c. Photo by J. Maertens de Noordhout (1930:fig.1b).

Fig. 35. Drawings by the author after Dieseldorff (1926:Plate 6, nr. 22 and 23).

Fig. 46b. Drawing by the author after Lothrop (1936: 24, fig. 20).

Fig. 47a-b. Drawings by the author after Stuart (2010:292, fig.12.5; Maya vase K4013).

Fig. 47c. Drawing SD-3541 by L. Schele @ David Schele, courtesy Ancient

Americas at LACMA.

Page 69. Drawings by the author after: Stone and Zender (2011:145),

and Stuart (2010:292, fig. 12.5).

Fig. 49a. Drawing by the author after Bassie-Sweet (2008:133, fig. 7.3). 
Fig. 49b. Drawing SD-3514 by L. Schele ( D David Schele, courtesy Ancient Americas at LACMA. Fig. 53a-c. Photos courtesy FRM.

Fig. 54a-b. Drawings SD-3543 by L. Schele (C David Schele, courtesy Ancient Americas at LACMA. Fig. 54c. Drawing by the author after Hellmuth (1987:271, fig. 59).

Fig. 54d,f. Drawings by the author after Spinden (1975:17, fig.1, e-f).

Fig. 54e. Drawing by the author after Butler (1940:256, fig. 23a).

Fig. 55. Drawing by the author after Stone and Zender (2011:156, nr. 3).

Fig. 56a. Drawing SD-236 by L. Schele (C) David Schele, courtesy Ancient Americas at LACMA.

Fig. 56b. Drawing by the author after Stuart (2006:16).

Fig. 57a-b. Photos by Guido Kayaert.

Page 76. Drawings by the author after Stone and Zender (2011:151).

Page 77. Drawing by the author after Stone and Zender (2011:225).

Fig. 58a. Drawing by the author after Looper (2003:91, fig. 3.18).

Fig. 58b-c. Drawings SD-172 (detail) and SD-140 by L. Schele (C) David Schele, courtesy

Ancient Americas at LACMA.

Fig. 58d. Drawing by the author after Stone and Zender (2011:224).

Fig. 59a-b. Drawings SD-3518 and SD-3542 by L. Schele @ David Schele, courtesy Ancient Americas at LACMA.

Fig. 62. Drawing SD-4517 by L. Schele @ David Schele, courtesy Ancient Americas at LACMA. Fig. 64a-b. Drawings SD-3531 by L. Schele (C David Schele, courtesy Ancient Americas at LACMA. Fig. 64c. Drawing by the author after Ruiz Pérez (2018:36,fig. 2.2a).

Page 81. Drawing by the author after Stone and Zender (2011:81).

Fig. 65b. Drawing SD-4018 by L. Schele @ David Schele, courtesy Ancient Americas at LACMA. Fig. 66a. Drawing JM00852 Copyright (C1999 John Montgomery, courtesy Ancient Americas at LACMA.

Fig. 68a-d. Drawings by the author after Lothrop (1936:53-58, fig. 58).

Fig. 69a. Photo by Jan De Meyer.

Fig. 71. Map (detail) A. L. Smith (1955:fig. 39), adapted by the author.

Fig. 72a-b. Drawings by the author after Velásquez (2015:263).

Fig. 72c. Drawing by the author after Stone and Zender (2011:109).

Fig. 73. Drawing by the author.

Fig. 74a. Map (details) A. L. Smith (1955:fig. 134), adapted by the author.

Fig. 74b. Drawing SD-3519 by L. Schele @ David Schele, courtesy Ancient Americas at LACMA, adapted by the author.

Page 86. Illustration (detail) from Sahagún (1979:vol. III, book XI, folio 62, pp. 214).

Annex 1

Photographs courtesy Archives of the University of Ghent (Archief Rijksuniversiteit Gent, ARUG).

Annex 2

All photographs by T. Debruyne and J. Montoya.

Annex 4

See illustration credits on pages 144-145. 


\section{ACKNOWLEDGMENTS}

I wish to thank Guido Kayaert for his support and motivation during many years.

I also want to express my gratitude to curator Pauline Van der Zee for the opportunity to study this extraordinary collection; to Charlotte Arnauld for sharing her work experience at Chich'en, her advice and motivation; to Karen Bassie-Sweet and Rogelio Valencia Rivera for their generous correspondence, insights, and for their valuable contribution to this work; to Ruud Van Akkeren and Chloe Andrieu for their valuable suggestions.

Many thanks to Victoria Solanilla, Mireille Holsbeke, Davide Domenici, Sofía Paredes, Claudia Quintanilla, Barbara Arroyo, Oswaldo Chinchilla, Camilo Luin, and Amelia Weymann, who, in one way or another, contributed to the search for material, references, personal contacts and for allowing us to visit the collections under their care. To Tom Debruyne for his great photographs, Hendrick De Moerloose for the good care of the artifacts of the collection, and Djamila Karibekova for her registration work. To Andrew Hirst and Jean Matton for their valuable contribution in proofreading the English and French texts. I also want to thank Walter Ochoa for the travel arrangements for our visit to Chich'en and guiding us in this and other sites.

Many thanks to Jan De Meyer for his valuable ideas and lay-out work.

Of course, all interpretations, errors, omissions, and spelling inaccuracies in this report are the author's responsibility. 


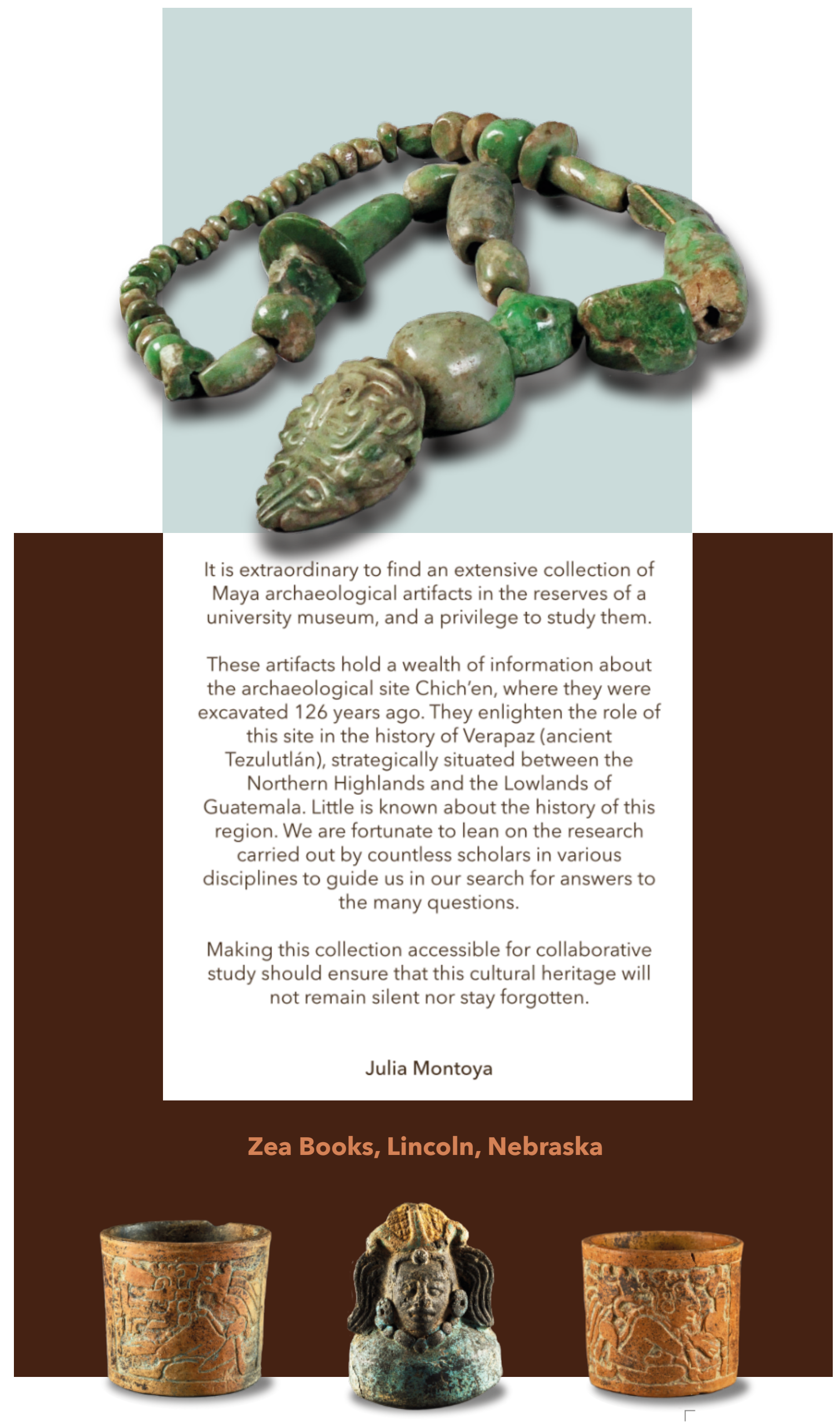

Nebraskina 